UNIVERSIDADE DE SÃO PAULO
FACULDADE DE ODONTOLOGIA DE RIBEIRÃO PRETO

Marina Xavier Pisani

Influência de uma solução experimental para higiene de próteses totais nas propriedades físicas e mecânicas de resinas acrílicas, dentes artificiais $e$ reembasadores resilientes. 


\title{
Influência de uma solução experimental para higiene de próteses totais nas propriedades físicas e mecânicas de resinas acrílicas, dentes artificiais $e$ reembasadores resilientes.
}

\begin{abstract}
Dissertação de mestrado apresentada à Faculdade de Odontologia de Ribeirão Preto da Universidade de São Paulo para obtenção do Título de Mestre em Reabilitação Oral, desenvolvida junto ao Departamento de Materiais Dentários e Prótese.
\end{abstract}

Orientadora: Prof ${ }^{\mathrm{a}}$ Dr$^{\mathrm{a}}$ Cláudia Helena Lovato da Silva

Ribeirão Preto

- 2008 - 
Autorizo a reprodução ou divulgação total ou parcial deste trabalho, por qualquer meio convencional ou eletrônico, para fins de estudo e pesquisa, desde que citada a fonte.

Ficha catalográfica elaborada pela Biblioteca Central do Campus USP - Ribeirão Preto

Pisani, Marina Xavier

Influência de uma solução experimental para higiene de próteses totais nas propriedades físicas e mecânicas de resinas acrílicas, dentes artificiais e reembasadores resilientes. Ribeirão Preto, 2008.

185 p.: 25 il.; $30 \mathrm{~cm}$

Dissertação de Mestrado, apresentada à Faculdade de Odontologia de Ribeirão Preto/ USP;

Área: Reabilitação Oral.

Orientador: Silva-Lovato, Cláudia Helena

1. Resina acrílica. 2. Dente artificial. 3. Reembasador resiliente. 4. Higienizadores. 5. Propriedades. 


\section{MARINA XAVIER PISANI}

Influência de uma solução experimental para higiene de próteses totais nas propriedades físicas e mecânicas de resinas acrílicas, dentes artificiais e reembasadores resilientes.

Dissertação de mestrado, apresentada à Faculdade de Odontologia de Ribeirão Preto da Universidade de São Paulo para obtenção do Título de Mestre em Reabilitação Oral, desenvolvida junto ao Departamento de Materiais Dentários e Prótese.

Ribeirão Preto

\section{Banca examinadora:}

Prof. Dr.

Instituição: Assinatura

Prof. Dr.

Instituição: Assinatura

Prof. Dr.

Instituição: Assinatura 
À Deus por ter me guiado durante todos os passos para a conquista do título de Mestre.

Aos meus pais, Carlos Magno e Ana Adélia, por acreditarem no meu futuro, estarem sempre prontos a me ouvir e me confortar. Sem o amor e a confiança de vocês seria difícil realizar meus sonhos. Cada conquista na minha vida é inteiramente dedicada a vocês!

Aos meus irmãos Magninho e Carolina, pela amizade e admiração que sentem por mim, pelos conselhos, força, companheirismo e amor em todos os momentos.

Ao Laurinho pela sua preocupação, carinho e amor. Por sempre estar do meu lado, me ajudando a nunca desanimar e me ensinando a viver, a lutar e nunca desistir. Você tem o maior coração do mundo.

Às minhas amigas de infância Ciça, Maura, Bruna, Marininha, Pathy e Cláudia. Apesar da distância, sempre tive 
vocês no meu coração e minha maior felicidade é vê-las felizes. Nossa amizade é para sempre!

Aos meus amigos da pós Graduação que me ensinaram muitas coisas e me divertiram durante este período.

Às minhas avós Virgínia, Cida e a toda a minha família por toda bondade, carinho e ternura comigo. 
À professora Helena de Freitas Oliveira Paranhos, Raphael Freitas de Souza e Valdir Muglia pelos ensinamentos, convivência e principalmente amizade durante a realização deste curso.

Aos professores do curso de Pós-Graduação em Reabilitação Oral, pelo grande ensinamento clínico e durante a apresentação dos seminários.

À CAPES pelo auxílio na bolsa de estudos que foi de fundamental importância para a realização desta pesquisa.

Aos funcionários do Lipen, Edson Volta e Ricardo de Souza Antunes, pelo auxílio na realização dos testes e por toda sua experiência.

À engenheira Ana Paula Macedo, do Departamento de Materiais Dentários e Prótese, pela sua imprescindível ajuda nas leituras e testes. 
Às secretárias Regiane de Cássia Tirado Damasceno, Ana Paula Xavier, Isabel Cristina Galino Sola e Regiane Cristina Moi Sacilotto por toda a competência e ajuda.

Aos meus amigos do curso de pós graduação e da clínica do Dape por compartilharem todos os ensinamentos.

A todos os meus amigos de graduação que foram fundamentais na minha vida e que sempre torceram por mim.

Aos protéticos do Departamento de Materiais Dentários e Prótese pelo auxílio nos trabalhos laboratoriais.

Ao Luiz Sérgio Soares por sua prontidão e opiniões para a realização deste projeto.

Ao Professor Gilberto Chiérese pelo fornecimento da solução de mamona para a realização dos experimentos. 
À minha orientadora, a Profa. Dra. Cláudia Helena Lovato da Silva.

Por ter me acolhido e trabalhado junto comigo desde a iniciação científica. Gostaria de agradecer, professora, por você ser quem você é: uma pessoa inteligente, educada, atenciosa, humana, que desperta em todos os alunos uma grande admiração. É em você que me espelho como futura professora, devido, principalmente, à sua humildade e sabedoria. Obrigada por estar do meu lado durante esta jornada em que aprendi muito, e que no doutorado esta parceria continue rendendo bons frutos. Por toda a amizade, crescimento pessoal e profissional, minha eterna gratidão! 
RESUMO 
PISANI, M.X. . Influência de uma solução experimental para higiene de próteses totais nas propriedades físicas e mecânicas de resinas acrílicas, dentes artificiais e reembasadores resilientes. 2008. 185p. Dissertação (Mestrado) - Faculdade de Odontologia de Ribeirão Preto, Universidade de São Paulo, Ribeirão Preto, 2008.

Este estudo avaliou resinas acrílicas convencional (RAC) e de microondas (RAM), dentes artificiais (Vipi, Biolux e Trilux) e reembasadores resilientes (Elite Soft e Mucopren Soft) após imersão em 3 soluções: água; hipoclorito de sódio 1\%; solução experimental de mamona $2 \%$. A dureza Knoop e cor das resinas e, dureza ShoreA, rugosidade e cor dos reembasadores foram analisadas em espécimes circulares $(15 \times 3 \mathrm{~mm})$; rugosidade e resistência à flexão das resinas, em espécimes retangulares $(10 \times 65 \times 3 \mathrm{~mm})$. A dureza e rugosidade dos dentes foram mensuradas na face palatina planificada e a cor, na face vestibular. Dez espécimes de cada material foram distribuídos, aleatoriamente, nos 3 grupos. Os ensaios foram realizados após obtenção dos espécimes e após 15 e 183 dias, simulando 3 anos de imersões diárias de 20 minutos e 18 meses de imersões diárias de 8 horas, respectivamente. Para os reembasadores, adicionou-se um período de 7 dias (18 meses de imersões diárias de 20 minutos). As variações $(\Delta \mathrm{T})$ dos dados foram submetidas aos Testes Anova e Tukey $(\mathrm{P}=0,05)$. Para $\Delta \mathrm{T}^{15}$, a RAC sofreu maior variação de dureza quando imersa em água $(\mathrm{P}=0,00)$; a RAM, após imersão em mamona $(\mathrm{P}=0,00)$. A mamona causou a maior variação na rugosidade $(\mathrm{P}=0,015)$. Todas as soluções aumentaram a rugosidade. A variação de cor não foi significante $(\mathrm{P}=24,46)$. $\mathrm{O}$ hipoclorito reduziu a resistência à flexão $(\mathrm{P}=0,37)$. Após $\Delta \mathrm{T}^{183}$, o hipoclorito e a mamona diminuíram a dureza da $\mathrm{RAC}(\mathrm{P}=0,00)$. A RAM sofreu a maior variação de rugosidade $(\mathrm{P}=0,01)$. $\mathrm{O}$ hipoclorito aumentou a rugosidade dos espécimes, porém não houve diferença entre as soluções $(\mathrm{P}=2,84)$. A RAC apresentou maior variação de cor após imersão em mamona $(\mathrm{P}=0,214)$. $\mathrm{O}$ hipoclorito e a mamona promoveram menor resistência à flexão para $\operatorname{RAM}(\mathrm{P}=0,89) . \mathrm{Em} \Delta \mathrm{T}^{15}$, o dente Vipi sofreu aumento da dureza e o Biolux, a maior variação $(\mathrm{P}=1,85)$. A mamona causou a maior variação e aumento da dureza $(\mathrm{P}=0,02)$. Para rugosidade, a mamona causou menor variação, mas com aumento $(\mathrm{P}=0,54)$. $\mathrm{O}$ dente Biolux apresentou a menor variação de cor $(\mathrm{P}=0,01)$. Após $\Delta \mathrm{T}^{183}$, o Trilux sofreu a maior variação na dureza $(\mathrm{P}=0,00)$. A mamona promoveu a menor variação $(\mathrm{P}=1,03)$. $\mathrm{O}$ dente Biolux apresentou a maior variação e aumento de rugosidade $(\mathrm{P}=0,001)$. Não houve variação de cor $(\mathrm{P}=16,45)$. Após $\Delta \mathrm{T}^{7}$, para dureza, Mucopren apresentou maior variação $(\mathrm{P}=0,05)$; não houve diferença entre as soluções $(\mathrm{P}=47,28)$. A imersão em água e hipoclorito aumentou a rugosidade do Mucopren. A solução de mamona causou a menor variação nesta propriedade $(\mathrm{P}=1,57)$. Para a cor, o Elite sofreu a maior variação quando imerso em hipoclorito; para o Mucopren, a mamona causou a maior variação $(\mathrm{P}=0,00)$. $\mathrm{Em} \Delta \mathrm{T}^{15}$, os materiais sofreram aumento da dureza. A maior variação ocorreu com Mucopren associado ao hipoclorito. ( $\mathrm{P}=0,33)$. O Elite sofreu maior variação da rugosidade que o Mucopren. Entre as soluções, não houve diferença estatística $(\mathrm{P}=2,32)$. Os materiais sofreram maior variação de cor após imersão em hipoclorito $(\mathrm{P}=0,00)$. Após $\Delta \mathrm{T}^{183}$, a maior variação de dureza foi apresentada pelo Mucopren em todas as soluções. A mamona gerou a menor variação $(P=2,64)$. Para a rugosidade, o Elite apresentou maior variação $(P=3,72)$. $O$ hipoclorito e a mamona tiveram comportamentos semelhantes $(\mathrm{P}=0,024)$. O hipoclorito causou maior alteração de cor para o Elite e a mamona, para o Mucopren $(\mathrm{P}=0,001)$. A solução experimental promoveu variação das propriedades dos materiais avaliados, não apresentando superioridade em relação ao controle positivo, independente do período de imersão.

Palavras chave: Resina acrílica, dente artificial, reembasador resiliente, higienizadores, propriedades. 
ABSTRACT 
PISANI, M.X. . Influence of an experimental solution for complete denture cleaning on the physical properties of acrylic resins, artificial teeth and soft liners. 2008. 185p. Dissertação (Mestrado) - Faculdade de Odontologia de Ribeirão Preto, Universidade de São Paulo, Ribeirão Preto, 2008.

This study evaluated conventional (RAC) and microwave-polymerized (RAM) acrylic resins, artificial teeth (Vipi, Biolux and Trilux) and soft liners (Elite Soft and Mucopren Soft) after immersion in 3 solutions: water, sodium hypochlorite 1\%; experimental solution of Riccinus communis (RC). The Knoop hardness and color alteration of resins, and shore A hardness, roughness and color alteration of soft liners were analyzed in circulars specimens $(15 \times 3 \mathrm{~mm})$, roughness and flexural strenght, in rectangular specimens $(10 \times 65 \times 3 \mathrm{~mm})$. Hardness and roughness of artificial teeth were measured on the flat palatine face and color in the vestibular face. Ten specimens of each material were randomly distributed in three groups. The tests were conducted after specimens obtention and after 15 and 183 days, simulating 3 years of daily immersions in 20 minutes and 18 months of daily immersions of 8 hours, respectively. A period of 7 days (18 months of daily immersions, 20 minutes) was added for soft liners. Data variation $(\Delta T)$ were submitted to ANOVA and Tukey $(\mathrm{P}=0.05)$. For $\Delta \mathrm{T}^{15}$ RAC underwent more variation in hardness when immersed in water $(\mathrm{P}=0.00)$ and the $\mathrm{RAM}$, after immersion in $\mathrm{RC}$ solution $(\mathrm{P}=$ $0.00)$. The $R C$ solution caused the largest variation in roughness $(\mathrm{P}=0.015)$. All solutions caused roughness increase. Color alteration was not significant $(\mathrm{P}=24.46)$. Sodium hypochlorite caused a decrease in flexural strenght $(\mathrm{P}=0.37)$. After $\Delta \mathrm{T}^{183}$, sodium hypochlorite and $\mathrm{RC}$ solution caused a decrease in RAC hardness $(\mathrm{P}=0,00)$. The RAM suffered the largest roughness variation $(\mathrm{P}=0.01)$. The hypochlorite caused an increase in roughness, but there was not differences between the solutions $(\mathrm{P}=2.84)$. RAC presented the largest color alteration after immersion in $\mathrm{RC}(\mathrm{P}=0.214)$. Sodium hypochlorite and RC caused the lowest values of flexural strenght for RAM ( $\mathrm{P}=0.89)$. In $\Delta \mathrm{T}^{15}$, Vipi underwent hardness increase and Biolux, the highest variation $(\mathrm{P}=1.85)$. RC caused the highest variation and hardness increase $(\mathrm{P}=0.02)$. For roughness, $\mathrm{RC}$ caused the lowest variation, with an increase $(\mathrm{P}=0.54)$. Biolux presented the lowest color alteration $(\mathrm{P}=0.01)$. After $\Delta \mathrm{T}^{183}$, Trilux underwent the highest hardness variation $(\mathrm{P}=0.00)$. $\mathrm{RC}$ caused the lowest variation $(\mathrm{P}=1,03)$. Biolux presented the highest variation, with an increase in roughness $(\mathrm{P}=0.001)$. There was not color variation $(\mathrm{P}=16.45)$. After $\Delta \mathrm{T}^{7}$, for hardness, Mucopren presented the highest variation $(\mathrm{P}=0.05)$; there was not differences between the solutions $(\mathrm{P}=47.28)$. The immersion in water and hypochlorite increased the roughness of Mucopren. The RC solution caused the lowest variation on this property $(\mathrm{P}=1.57)$. About color, Elite underwent the highest variation after immersion in hypochlorite; for Mucopren, RC caused the highest variation $(\mathrm{P}=0.00)$. In $\Delta \mathrm{T}^{15}$, the materials suffered hardness increase. The highest variation occured for Mucopren associated with hypochlorite $(\mathrm{P}=0.33)$. Elite underwent most roughness variation than Mucopren. There was not statistics differences between the solutions $(\mathrm{P}=2.32)$. Both materials suffered color alteration after immersion in hypochlorite $(\mathrm{P}=0.00)$. After $\Delta \mathrm{T}^{183}$, the highest hardness alteration was presented for Mucopren in all solutions. The RC caused the lowest variation $(\mathrm{P}=2.64)$. For roughness, Elite presented the highest variation $(\mathrm{P}=3.72)$. Sodium hyochlorite and Riccinus communis was statistically equal $(\mathrm{P}=0.024)$. Hypochlorite caused the the highest color alteration for Elite and Riccinus communis for Mucopren. $(\mathrm{P}=0,001)$. The experimental solution caused alterations on the properties of all tested materials, showing no superiority to the positive control, regardless of the immersion period.

Keywords: Acrylic resin, artificial teeth, soft liners, cleansers, properties. 
SUMÁRIO 


\section{SUMÁRIO}

RESUMO

ABSTRACT

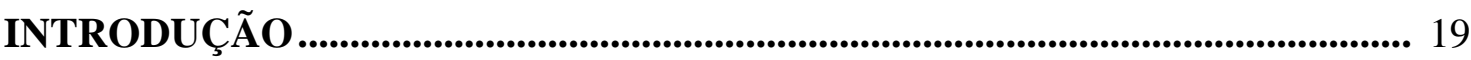

REVISÃO DE LITERATURA ............................................................................ 23

1. Higiene de Próteses totais: uma visão geral.......................................................... 24

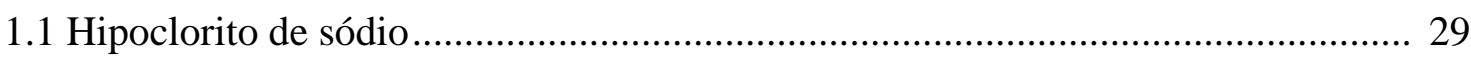

1.2 Solução à base de mamona (Riccinus comunis).................................................. 35

2. Materiais constituintes da prótese total .............................................................. 39

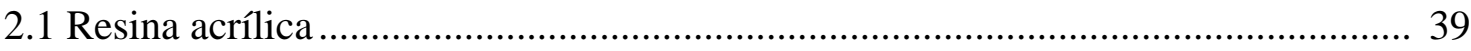

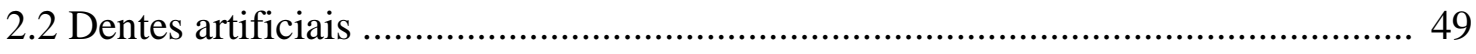

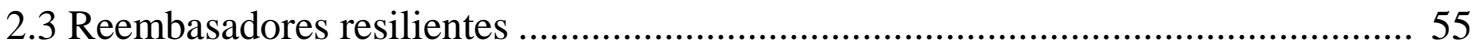

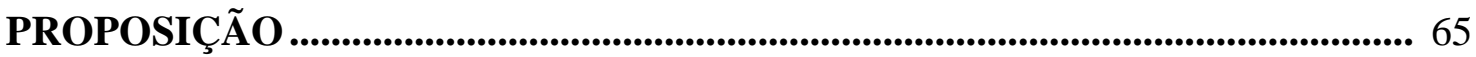

MATERIAL E MÉTODOS.................................................................................. 67

1. Preparo dos corpos-de-prova ............................................................................. 68

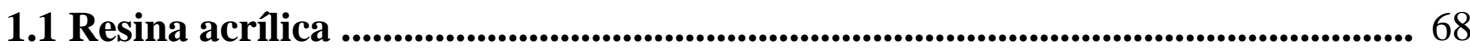

1.1.1 Confecção dos corpos-de-prova para testes de dureza e alteração de cor............ 68

1.1.2 Confecção dos corpos-de-prova para testes de resistência à flexão e

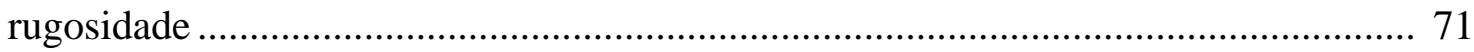

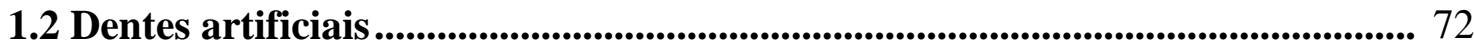

1.2.1 Confecção dos corpos-de-prova para testes de dureza, alteração de cor e

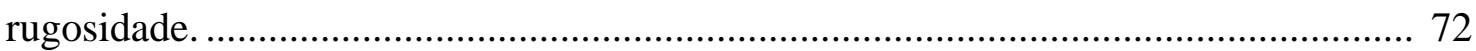

1.3 Reembasadores resilientes.................................................................................. 73

1.3.1 Confecção dos corpos-de-prova para testes de dureza, alteração de cor e

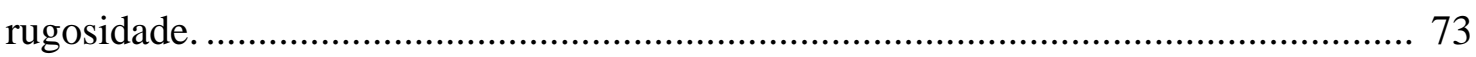

2. Formação dos grupos................................................................................ 74

3. Períodos de imersão ...................................................................................................... 74

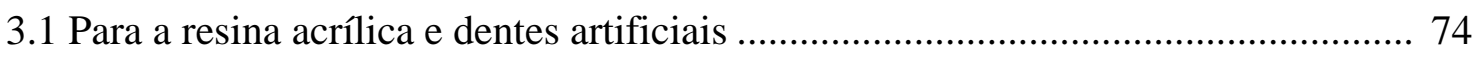

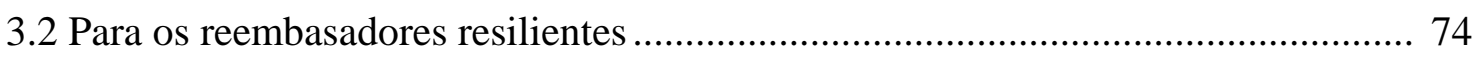

4. Realização dos testes .......................................................................................... 76

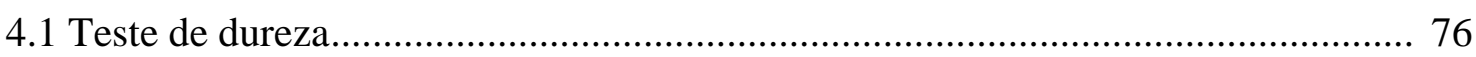

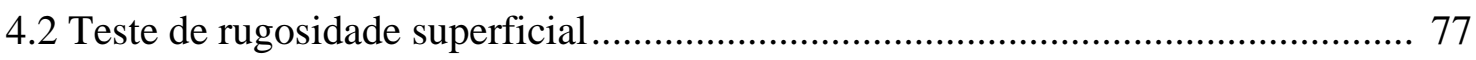

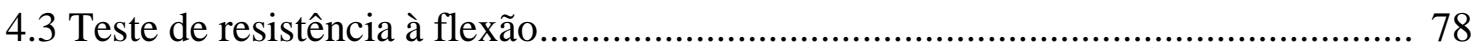

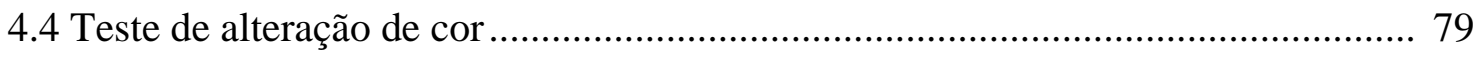


5. Análise dos dados .......................................................................................................... 80

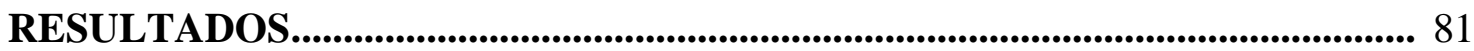

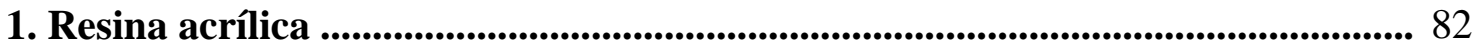

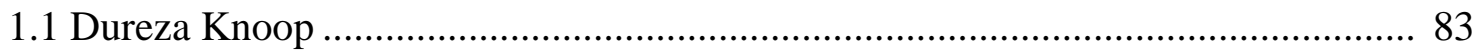

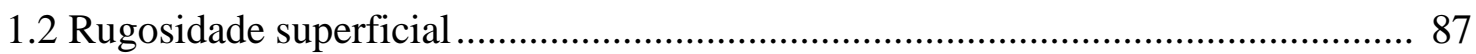

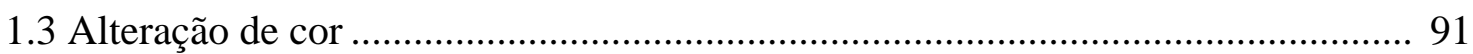

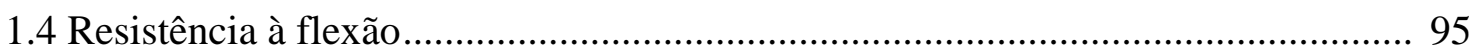

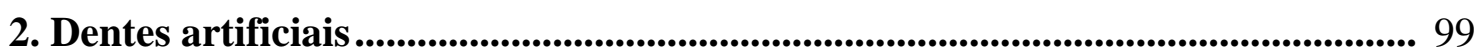

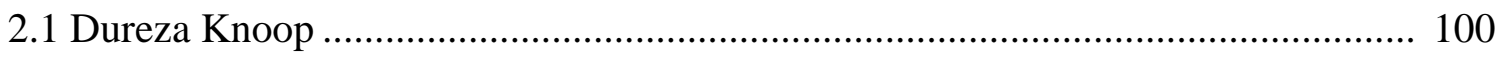

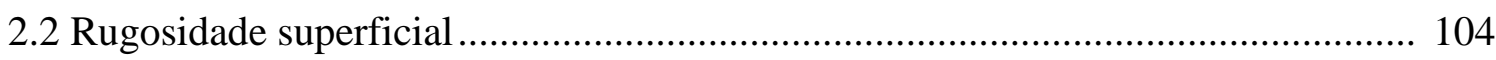

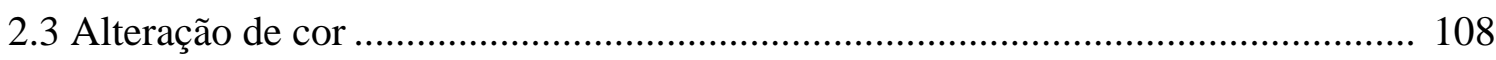

3. Reembasadores resilientes................................................................................... 112

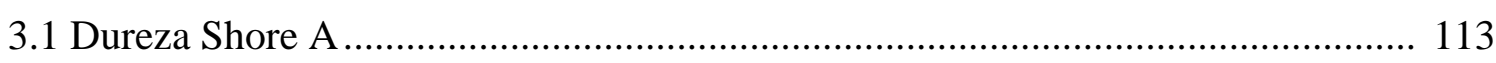

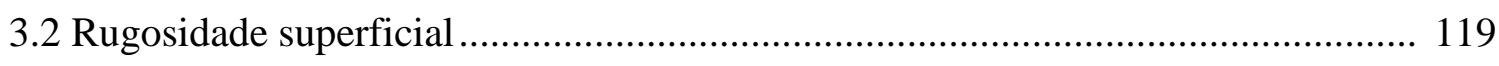

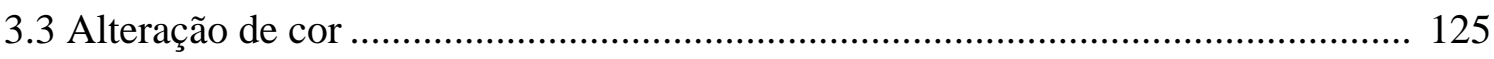

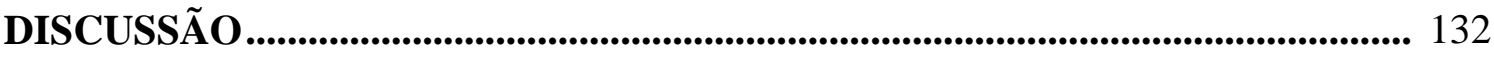

Considerações iniciais ...................................................................................................... 133

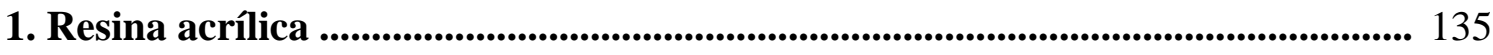

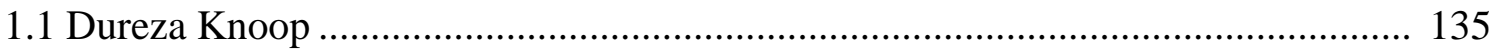

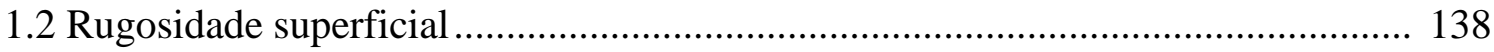

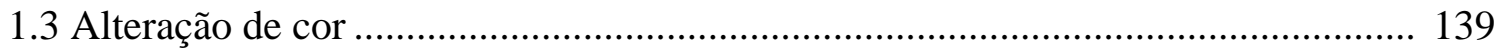

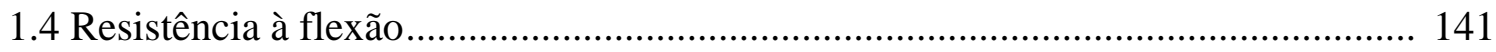

2. Dentes artificiais .......................................................................................................... 144

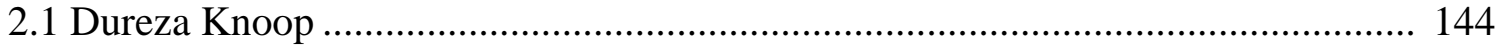

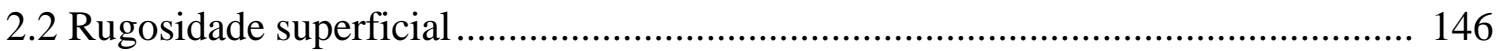

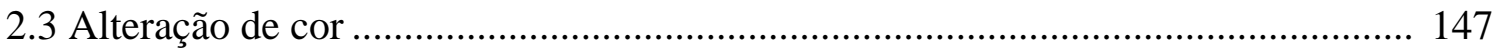

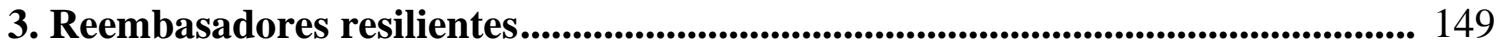

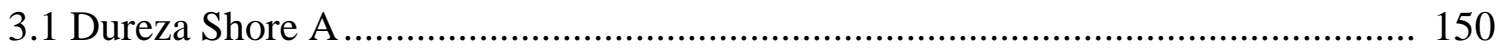

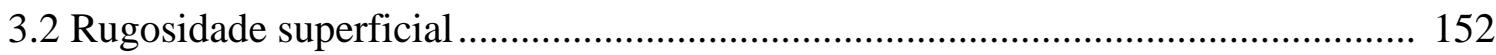

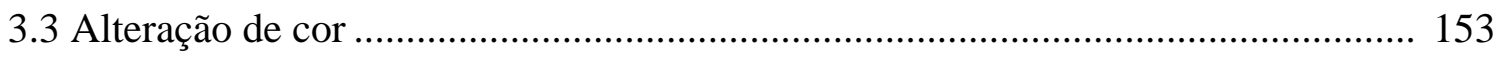

Considerações finais.......................................................................................... 156

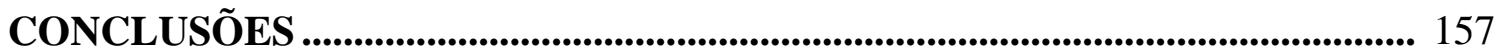

REFERÊNCIAS BIBLIOGRÁFICAS................................................................... 159 
A reabilitação oral com próteses totais tem como objetivos principais o restabelecimento da estética e da função bem como do bem estar físico e psicológico do paciente.

Este aparelho protético é constituído por uma base confeccionada em resina acrílica termicamente polimerizada utilizada há mais de 60 anos, podendo ser associado a dentes artificiais de resina acrílica ou porcelana. A resina acrílica é um composto de polimetilmetacrilato (ANUSAVICE, 2005) e apresenta várias características e propriedades desejáveis como estética satisfatória, boa resistência, baixo custo e facilidade de manipulação (PHILLIPS, 1984). O método de polimerização mais empregado para as resinas acrílicas é realizado em água aquecida, porém a polimerização pela energia de microondas vem sendo continuamente estudada devido à facilidade e efetividade na confecção de próteses, ao aquecimento rápido e uniforme e à economia de tempo no processamento (KIMURA et al., 1983; KIMURA; TERAOKA; SAITO, 1984). Devido à característica rígida do material, reembasadores resilientes vêm sendo comumente associados.

O uso clínico de materiais reembasadores macios para próteses totais foi citado pela primeira vez em 1943 (TYLMAN, 1943). Desde então o seu uso tem se tornado cada vez mais popular por promover maior conforto aos usuários de dentaduras devido à sua capacidade de absorção de forças (GOLL; SMITH; PLEIN, 1983; NIKAWA et al., 1994), distribuição da carga funcional sobre o rebordo (AYDIN et al., 1999; SINOBAD et al., 1992) e de adaptação à superfície protética e retenção da prótese (CRAIG; GIBBONS, 1961). Além disso, estes materiais têm sido utilizados nos tratamentos de rebordo atrofiado, bruxismo, xerostomia, e em próteses antagônicas à dentição natural (BOUCHER; HICKEY; ZARB, 1975).

Uma prótese total apresenta, de forma geral, vida útil de aproximadamente 7 anos (ZARB; BOLENDER; CARLSSON, 2000), período este ditado pelas características da resina acrílica, dentes artificiais e padrão de reabsorção óssea do paciente. No entanto, para que este período seja atingido com condições clínicas aceitáveis é necessário o adequado controle e manutenção destes aparelhos protéticos.

A durabilidade das próteses totais e a saúde da mucosa oral estão intimamente ligadas à higiene realizada pelo paciente (BUDTZ-JORGENSEN, 1979). Levantamentos bibliográficos apontam uma condição precária na higiene das próteses ainda nos dias atuais, situação esta associada à falta de orientação (DIKBAS; KOKSAL; CALIKKOCAOGLU, 2006; HOAD-REDDICK; GRANT; GRIFFITHS, 1990), às características intrínsecas ao aparelho, à diminuição da destreza manual dos pacientes (DILLS et al., 1988; KULAK- 
OZKAN; KAZAZOGLU; ARIKAN, 2002), bem como a ineficácia dos produtos para limpeza das próteses (BUDTZ-JORGENSEN, 1979) e ainda, à falta de materiais específicos para higiene de próteses totais disponíveis no mercado brasileiro.

Outro fator a ser salientado é que, a maioria das propagandas relacionadas à higiene bucal, é dirigida para a preservação dos dentes naturais e seus tecidos de suporte, sendo deficiente a conscientização da importância da boa higiene aos usuários de prótese. Os produtos de higiene indicados para próteses totais são pouco divulgados, ou ainda, divulgados de maneira errônea.

O produto ideal para higiene dos aparelhos protéticos deve apresentar características como: facilidade de manuseio; efetividade na remoção dos depósitos orgânicos, inorgânicos e manchas; ação bactericida e fungicida; atoxicidade; compatível aos materiais constituintes do aparelho e apresentar baixo custo.

Os métodos propostos para a higiene de próteses podem ser divididos em dois grupos principais: mecânicos e químicos (ABELSON, 1985; BUDTZ-JØRGENSEN, 1979; COUNCIL ON DENTAL MATERIALS, EQUIPMENTS AND INSTRUMENTS, 1983; JAGGER; HARRISON, 1995).

Os métodos mecânicos são classificados em escovação (com água, sabão, dentifrícios ou abrasivos) e aparelhos ultra-sônicos. Os métodos químicos, de acordo com seus componentes principais e mecanismo de ação, são classificados em hipocloritos, peróxidos, peróxidos neutros com enzimas, enzimas, ácidos, drogas brutas e enxagüatórios para dentaduras (NIKAWA et al., 1999).

A escovação é o método mais comumente empregado entre os usuários de próteses totais e consiste no uso da escova tendo como agentes auxiliares a água, o sabão, os dentifrícios ou pós abrasivos (NIKAWA et al., 1999; PARANHOS; PARDINI; PANZERI, 1991; POLYZOIS, 1983). Tem a vantagem de ser um método simples, de baixo custo e eficaz na remoção de manchas e depósitos orgânicos (ANDRUCIOLLI et al., 2004; BARNABÉ et al., 2004; SILVA-LOVATO; PARANHOS; ITO, 2002). Possui as desvantagens de ser de difícil execução para pacientes com problemas de coordenação motora (ABELSON, 1985; JAGGER; HARRISON, 1995), provocar o desgaste da resina acrílica (HARRISON; JOHNSON; DOUGLAS, 2004; LAI et al., 2004) e causar danos às superfícies de materiais de reembasamento pelo uso incorreto (HASELDEN et al., 1998). Porém, estudos clínicos mostram que a escovação, quando realizada de forma adequada, com escova macia e dentifrício específico consiste em método eficaz na redução dos níveis de biofilme em próteses totais (ANDRUCIOLLI et al., 2004; PARANHOS et al., 2000; TARBET et al., 
1984).

A higienização por agentes químicos consiste na imersão do aparelho em soluções que possuem ação solvente, detergente, bactericida e fungicida. Tal método de limpeza, no qual estão inseridas principalmente as soluções de peróxidos e hipocloritos alcalinos, apresenta-se como vantajoso, pois as soluções englobam todas as áreas da prótese total, resultando em uma limpeza satisfatória e os danos ao aparelho protético, comparativamente ao método mecânico (escovação), no que se refere à abrasão, estão diminuídos (BUDTZ-JØRGENSEN, 1979). Uma vez que o procedimento é simples, ele é facilmente executado por pessoas debilitadas ou que perderam a coordenação motora e que não podem se adaptar à escovação. Porém, como desvantagens principais, podem ser citadas a possibilidade de clareamento dos materiais de confecção das próteses, a corrosão de componentes metálicos e o alto custo dos produtos no mercado (ABELSON, 1985; BUDTZ-JØRGENSEN, 1979; COUNCIL ON DENTAL MATERIALS AND EQUIPMENTS, 1983; JAGGER; HARRISON, 1995).

Tais soluções podem ser utilizadas isoladamente ou combinadas com a escovação, sendo esta última opção rotineiramente recomendada (GORNTISKY et al., 2002; LEE et al., 1985; NIKAWA et al., 1999; SHEEN; HARRISON, 2000). Porém, experimentos clínicos comparativos mostram resultados contraditórios em relação à efetividade desses produtos, sendo divulgado superioridade do método químico (CHAN et al., 1991; DILLS et al., 1988), da escovação (TARBET et al., 1984) ou da associação de ambos os métodos (MORAN et al., 1983; PARANHOS et al., 2007).

Quando um método de higiene é avaliado faz-se necessário analisar não somente a eficácia do produto higienizador no controle do biofilme, mas também sua ação sobre os materiais constituintes da prótese (GARCIA et al., 2004; HARRISON; JOHNSON; DOUGLAS, 2004; NEPPELENBROEK et al., 2005; RICHMOND et al., 2004; SATOH et al., 1990; TANQUE et al., 2000). O objetivo da imersão da prótese em produtos químicos é a obtenção de limpeza e descontaminação, sendo importante que o processo não envolva nenhuma alteração física, mecânica, ou química dos materiais que constituem as próteses.

Dessa forma, o estabelecimento de concentrações mínimas, com ação bactericida e que promovam a longevidade das resinas acrílicas, dentes artificiais e reembasadores resilientes faz-se necessário. A busca por um higienizador ideal e que seja acessível ao paciente é imprescindível. A análise in vitro das propriedades de tais materiais frente às imersões em produtos químicos de higiene por períodos prolongados torna-se importante. 


\section{Higiene de Próteses totais: uma visão geral}

As pesquisas na área odontológica têm promovido grandes avanços. Apesar do advento da Implantologia, ainda é comum o grande número de pacientes que requerem a reabilitação oral com próteses totais convencionais. A higiene de próteses totais torna-se essencial, uma vez que contribui para a saúde bucal, estética e ausência de odores (NEIL, 1968). Cabe ao cirurgião dentista a orientação correta quanto aos materiais e os métodos de higiene (MARTINS et al., 2004).

O biofilme presente na superfície da prótese total é um dos fatores etiológicos da Candidíase e outras infecções locais ou sistêmicas (NIKAWA; HAMADA; YAMAMOTO, 1998). A aderência de microrganismos e debris é favorecida pela rugosidade e pela superfície topográfica irregular das próteses (SHAY, 2000). Os fungos mais comumente presentes na saliva dos usuários de prótese totais são do gênero Candida e apresentam alta afinidade pela resina acrílica (SHAY; RENNER; TRUHLAR, 1997). Segundo Budtz-Jorgensen (1979), um regime rotineiro de higiene deveria ser indicado para remover e prevenir o acúmulo de biofilme, restos alimentares, cálculos e descolorações exógenas.

Tendo em vista a importância da limpeza das próteses, as pesquisas visando um produto ideal para a higiene começaram a aumentar. Porém, os testes de eficácia desses produtos são complexos e os resultados relatados são variados e freqüentemente dependem das condições experimentais (COUNCIL ON DENTAL MATERIALS, INSTRUMENTS AND EQUIPAMENTS, 1983). Segundo Abelson (1985), o produto ideal para a higiene deveria ser de fácil uso, promover remoção efetiva de depósitos orgânicos e inorgânicos, ser bactericida e fungicida, não tóxico ao paciente e não provocar nenhum dano aos materiais usados nas próteses.

Sexson e Phillips (1951) avaliaram os efeitos dos procedimentos de limpeza sobre a superfície das resinas acrílicas. Previamente aos ensaios laboratoriais, foi realizado um estudo para examinar o método de limpeza mais popular utilizado pelos pacientes. Os autores observaram que os pacientes utilizavam diferentes tipos de produtos, até mesmo desinfetantes caseiros, para higienização de próteses.

Langwell (1955), em um dos precursores trabalhos sobre higienizadores, classifica-os em hipocloritos alcalinos, peróxidos alcalinos e ácidos clorídricos diluídos.

Abere (1979) divide os higienizadores em agentes químicos para imersão (hipocloritos alcalinos, peróxidos alcalinos, ácidos diluídos e enzimas), ultra-som, escovação e pastas ou abrasivos para dentaduras. Afirma que a remoção de biofilme e resíduos alimentares das 
próteses deve ser realizada diariamente com escova específica para prótese e sabão suave. $\mathrm{O}$ uso de soluções químicas de imersão deve ser proposto para pacientes debilitados ou idosos que não conseguem realizar a escovação. Em áreas de difícil acesso da escova deve-se utilizar uma solução diluída de alvejante para fricção na superfície da prótese.

Budtz-Jorgersen (1979) publicou uma revisão de literatura sobre os materiais e métodos para higienizar próteses, e os diferentes meios para mantê-las livres de biofilme. Os métodos de higiene foram divididos em mecânicos (escovação, pastas, pós e ultra-som) e químicos (peróxido alcalino, hipoclorito alcalino, desinfetantes, enzimas e ácidos orgânicos ou inorgânicos diluídos). De acordo com o autor, a limpeza mecânica é um método efetivo na higienização da prótese e manutenção da mucosa saudável. Para evitar desgaste excessivo, deve-se utilizar dentifrício de baixa abrasividade e escova macia. A orientação do paciente deve ser feita de forma cuidadosa, pois o biofilme formado na prótese é de difícil remoção. Agentes químicos de limpeza são importantes alternativas, principalmente para pacientes geriátricos, ou com dificuldades motoras, que fazem uso de prótese. A imersão diária da prótese em solução de peróxido alcalino durante a noite constitui um meio de limpeza efetivo e seguro. Segundo o autor, a solução de hipoclorito é efetiva, porém, seu uso deve ser limitado a 1 vez por semana, devido a sua capacidade de branqueamento. Soluções à base de ácido hidroclorídrico são perigosas e devem ser evitadas. As soluções de gluconato de clorexidina são inadequadas devido ao manchamento, porém podem ser prescritas para imersão da prótese como droga específica antimicótica no tratamento de Candidíase Atrófica Crônica. O autor salienta que as pesquisas devem ser direcionadas para o desenvolvimento de agentes higienizadores que não afetem a cor e a superfície das próteses. Os procedimentos clínicos e laboratoriais utilizados durante a confecção do aparelho protético devem ser direcionados para obtenção de superfícies lisas, homogêneas e polidas, visando facilitar sua limpeza.

Abelson (1985) investigou a importância da higiene de próteses e os métodos utilizados pelos pacientes. $\mathrm{O}$ autor afirmou que a escovação da prótese com pasta abrasiva é o melhor método de higienização, mas que este método pode ser de difícil realização para pacientes idosos ou com deficiência motora. As soluções de hipoclorito são muito eficientes, porém, apresentam sabor e odor desagradáveis. Segundo o autor, esta imersão pode ser seguida de outra em solução de peróxido. Os usuários de prótese devem entender que há razão além da estética para a limpeza da prótese, e que os produtos para higienização proporcionam saúde.

Lee et al. (1985) chamaram a atenção que vários métodos de limpeza de próteses totais 
tinham sido avaliados quanto à sua eficácia e que nenhum foi aceito como o melhor. Os autores avaliaram métodos populares de limpeza e tentaram desenvolver uma maneira simples de higienização. Pelos resultados obtidos, o método combinado (escovação e higienizador do tipo imersão) foi o método mais efetivo de limpeza, sendo que a escovação deve ser precedida pela imersão.

Segundo Devlin e Bedi (1988), nota-se que na prática clínica odontológica, pouco tempo de trabalho é destinado às instruções e cuidados de uso das próteses totais. Um estudo sobre a saúde oral de usuários de dentaduras revelou que, entre os indivíduos que haviam perdido os dentes remanescentes nos últimos 10 anos, somente 39\% relataram ter recebido informações básicas de seus dentistas, como por exemplo, quanto ao uso ou não de suas próteses à noite. Para os conceitos básicos de saúde serem mais efetivamente aplicados, os cirurgiões-dentistas devem ser claros quanto às instruções transmitidas aos pacientes. Quando o profissional de saúde comunica-se bem, ele aumenta a satisfação de seu paciente com o tratamento. De acordo com o autor, há uma relação positiva entre a satisfação do paciente e as informações relevantes transmitidas de forma clara na clínica médica. A mesma relação tem sido mostrada na prática dental. O cirurgião-dentista deve dispor de maior tempo instruindo os pacientes com princípios básicos de cuidados com as próteses e saúde bucal e essas instruções devem ser transmitidas aos pacientes de forma oral e por escrito e devem orientar quanto aos cuidados com as próteses totais durante a noite, quanto à mastigação, salivação, limpeza, limitações e tempo de vida útil dos aparelhos.

Hoad-Reddick et al. (1990) pesquisaram a higiene de próteses em população idosa. Os voluntários selecionados foram examinados e questionados quanto à higienização das próteses. Os autores observaram: alto nível de edentulismo; 84,2\% dos voluntários higienizavam as próteses sem ajuda de outra pessoa; o método de higienização considerado mais satisfatório (escovação e imersão) era utilizado por 40,2\%; 79,1\% das próteses eram higienizadas diariamente; $83,3 \%$ dos pacientes apresentaram-se sem qualquer orientação quanto à higienização; Candidíase Atrófica Crônica e queilite angular foram observadas duas vezes mais em pacientes portadores de próteses com higiene insatisfatória. Os autores concluíram que apenas 40\% das próteses encontravam-se adequadamente limpas e que a maioria dos idosos não sabe como higienizá-las. Concluíram, portanto, que a educação para a saúde oral deve ser direcionada para esses problemas, e que os dentistas devem encorajar os portadores de próteses a realizar revisões constantes, para que próteses antigas, com má adaptação e relacionadas com alta incidência de Candidíase Atrófica Crônica possam ser detectadas para a manutenção da saúde desses pacientes. 
Paranhos, Malachias e Pardini (1991) estudando o método de higiene ideal, afirmaram que uma limpeza efetiva pode ser obtida por meio da associação dos métodos mecânicos (escovação e ultra-som) e químicos (hipocloritos alcalinos, peróxidos alcalinos, ácidos, enzimas e desinfetantes). A instrução quanto ao uso de higienizadores deve ser efetiva, sendo de responsabilidade do paciente a manutenção da higiene por meio de cuidados diários.

Jagger e Harrison (1995) realizaram um estudo para verificar o método de limpeza mais popular utilizado entre portadores de próteses totais e parciais removíveis e aconselhar sobre a higienização de próteses. Um questionário simples com 5 perguntas sobre a higienização e limpeza das próteses foi preenchido por 100 pacientes. Os resultados mostraram que muitos pacientes não sabem como higienizar as próteses satisfatoriamente, sendo que $46 \%$ dos pacientes afirmaram nunca ter recebido qualquer orientação de higiene. $\mathrm{O}$ peróxido alcalino foi o agente químico de limpeza mais comumente utilizado. Os autores afirmaram que a escovação é um método eficiente de higienização e que exige, porém, grau de destreza manual, nem sempre encontrado em todos os indivíduos. As próteses com estrutura metálica podem ser higienizadas pela imersão em solução de peróxido alcalino associado a enzimas proteolíticas. Para as próteses reembasadas com material resiliente temporário, os autores indicaram imersão em hipoclorito alcalino por 20 minutos, e para os materiais permanentes, escovação suave com escova macia, água e sabão.

Kulak-Ozkan, Kazazoglu e Arikan (2002), avaliaram os hábitos de higiene oral, limpeza das próteses e a presença de leveduras e Candidíase Atrófica Crônica em população idosa. Foram avaliados 70 pacientes portadores de próteses totais duplas. Os autores observaram: 1) 55,7\% dos pacientes estavam livres de Candidíase, enquanto 54,3\% apresentaram a doença classificada como leve, difusa ou granular; 2) a cultura da região do palato mostrou crescimento de diferentes tipos de Candida em 37 pacientes (sendo a Candida albicans a mais frequente), e 43 pacientes livres de levedura; 3) 34 pacientes apresentaram pobre higiene de suas próteses, 25 deficientes e 11 excelentes; 4) 18 pacientes relataram higienizar a prótese ocasionalmente, 20 uma vez por dia e 32 mais de uma vez por dia; 5) 40 pacientes relataram somente hábitos de escovação, 4 somente de imersão em solução, 12 somente imersão em água e 6 pacientes relataram escovar e imergir as próteses. Houve correlação significativa entre higienização da prótese deficiente e Candidíase. Assim, os autores afirmaram que os profissionais devem estar atentos para a correta higiene das próteses pelos pacientes.

Kanli, Demirel e Sezgin (2005) realizaram um estudo para avaliar a presença de Candidíase, limpeza de próteses e hábitos de higiene na população idosa. Um total de 42 
pacientes usuários de prótese total superior e com idade média de 74 anos foram selecionados. As informações sobre a idade da prótese, hábitos e higiene foram obtidas por meio de questionários. $\mathrm{O}$ índice de Schubert foi utilizado para determinar a limpeza das próteses totais e, para o exame citológico, amostras microbianas do palato foram colhidas. Os autores afirmaram haver intensa relação entre Candidíase e freqüência de limpeza e que não houve diferença estatística significante entre Candidíase e o método de limpeza empregado. A relação entre a idade da prótese total e presença de Candidíase não foi significante. Somente $16,7 \%$ das próteses apresentaram-se adequadamente limpas, e ainda concluíram que as próteses mais velhas tendem as ser mais sujas do que as novas.

Dikbas, Koksal e Calikkocaoglu (2006) realizaram um estudo para investigar a higiene de dentaduras em um hospital universitário. Foram entrevistados 234 pacientes por meio de um questionário para obter informações acerca do uso de higienizadores e da freqüência de higienização empregada por eles. As próteses foram classificadas como limpas, sujas ou extremamente sujas baseados nos níveis de debris e manchas. A mucosa oral também foi examinada. O regime de limpeza mais empregado foi a escovação com pasta (40,59\%) enquanto somente um paciente relatou imergir a prótese. Os resultados mostraram que 38,9\% dos pacientes não estão satisfeitos com o método empregado para higiene, 82,9\% mostraramse descontentes com as informações recebidas de seus dentistas sobre a higienização de suas próteses. Somente 11,9\% dos pacientes apresentaram dentaduras adequadamente limpas. Concluíram que as próteses mais antigas tendem a ser mais sujas que as novas e têm maior chance de apresentar Candidíase e que, a maioria dos pacientes ainda não sabe como higienizar adequadamente suas próteses.

Silva-Lovato et al. (2006) realizaram um estudo para investigar a variação no grau de instruções de usuários de próteses totais bem como os materiais e métodos de higiene utilizados por eles para a higiene das próteses. Informações coletadas no ano de 1989 foram comparadas com as informações obtidas em 2004. Em 1989, 93,87\% dos entrevistados relataram utilizar escova dental e dentifrício para higiene de próteses totais. No ano de 2004, 95\% dos usuários entrevistados relataram utilizar o mesmo método de higiene. Quanto ao grau de instrução, mais de $80 \%$ dos pacientes não receberam orientação quanto à higienização ou quanto à necessidade de visita periódica ao cirurgião-dentista no ano de 1989, mas em 2004 pôde-se notar que houve uma melhora significativa nesse quadro, uma vez que $52 \%$ dos pacientes não receberam orientação quanto à higienização e $77 \%$ não receberam orientação quanto à visita periódica ao cirurgião-dentista. Somente 3 pacientes relataram o uso de outros métodos, como água sanitária e bicarbonato de sódio. 
Os dados encontrados neste levantamento indicaram que a higiene das próteses era realizada três vezes ao dia pelo maior número de pacientes tanto para o ano de 1989 (72,4\%) como para $2004(79 \%)$.

Com base nos trabalhos apresentados, pôde-se perceber que os cuidados com a manutenção e higiene das próteses totais são precários ainda nos dias atuais e que, os métodos de higiene são variados, cada qual com suas vantagens e desvantagens. Dessa forma, é salutar que estudos avaliando os métodos existentes se desenvolvam, bem como a análise de novas formulações, com baixo custo, eficazes na higiene e não deletérias aos materiais constituintes da prótese.

Embasado neste pensamento e estudando a literatura pertinente, foi encontrada uma possibilidade de avanço se identificada a viabilidade de uso de uma solução à base de Riccinus comunis (mamona) como higienizador de próteses totais. Para melhor direcionamento e planejamento do presente trabalho, buscou-se na literatura informações sobre um produto de imersão que apresentasse resultados cientificamente comprovados para servir como padrão ouro de comparação à solução experimental. Desta busca, ressaltou-se o hipoclorito de sódio.

\subsection{Hipoclorito de sódio}

Os principais higienizadores químicos para imersão de próteses constituem-se em soluções de hipoclorito e peróxidos alcalinos (ABELSON, 1981).

Em Odontologia, as soluções de hipoclorito de sódio foram introduzidas como antisépticos em 1835, tendo sido a primeira solução química usada rotineiramente para imersão de próteses totais (ABERE, 1979; LANGWELL, 1955). A recomendação clínica do uso de soluções alvejantes domésticas diluídas para a higienização e esterilização das próteses acrílicas é comum (JAGGER; HARRISON, 1995; SMITH, 1966). O hipoclorito de sódio é efetivo na remoção de manchas e na dissolução da estrutura polimérica da matriz orgânica formadora do cálculo (BUDTZ-JORGENSEN, 1979). Além disso, é um agente bactericida e fungicida (ABELSON, 1985; BUDTZ-JORGENSEN, 1979; WEBB et al., 1995). Dentre as desvantagens deste agente higienizador estão a corrosão de componentes metálicos, como estruturas de cobalto-cromo para próteses parciais removíveis (BUDTZ-JORGENSEN, 1979), odor desagradável e a possibilidade de provocar clareamento da resina acrílica dependendo da concentração e do tempo de imersão (MACCALLUM et al., 1968; SMITH, 1966). 
O hipoclorito de sódio pode ser empregado na concentração de 5,25\% que é uma combinação de cloro ativado com bases fortes; ou em concentrações menores, de $2 \%, 1 \%$ ou até mesmo diluída a $0,5 \%$. O tempo de imersão é variável de acordo com a concentração utilizada podendo oscilar entre 5 e 30 minutos, não sendo recomendo exceder mais de 30 minutos (COUNCIL ON DENTAL THERAPEUTICS; CONCIL ON PROSTHETIC SERVICES AND DENTAL LABORATORY RELATIONS, 1985).

Hutchins e Parker (1973) realizaram um estudo para investigar 11 higienizadores químicos quanto à capacidade de remoção de biofilme. Participaram deste estudo 7 pacientes usuários de próteses totais e próteses parciais removíveis, confeccionadas com resina acrílica, liga cobalto-cromo e porcelana. O estudo foi dividido em várias fases. Os resultados mostraram que na primeira fase, o hipoclorito de sódio (Mersene) foi a única solução a remover o biofilme após 15 minutos ou 6 horas de imersão, sendo também efetivo nas imersões durante a noite por uma semana. Este estudo demonstrou que a imersão regular durante a noite em hipoclorito alcalino (Mersene) foi efetivo contra o acúmulo de biofilme, e que não causou clinicamente efeitos adversos nos materiais das próteses. Os autores também advertem sobre a dificuldade de remoção do biofilme maduro em comparação ao biofilme acumulado por 24 horas, por isso as próteses devem ser escovadas até sua limpeza completa e posteriormente imersas no período noturno.

Shannon e Starcke (1978) conduziram testes laboratoriais e clínicos para testar a habilidade de remoção de biofilme de produtos de higiene específicos para limpeza de próteses. Amostras de resina acrílica foram imersas em Polident Tablets (Block Drug Co.), Mersene (Colgate-Palmolive Co.), Sonac Solution e Sonac Electrosonic (Cooper Laboratories), VA cleanser (higienizador de próteses para imersão) e água deionizada (controle), com imersões de 15 minutos. Os tratamentos com Mersene e higienizador VA foram mais efetivos que com o Polident. A solução Sonac isolada e utilizada no aparelho Sonac Electrosonic foi mais efetiva que a imersão em Polident, porém menos eficaz que Mersene e VA. No estudo clínico, as imersões durante a noite em Mersene e VA também foram efetivas quanto à limpeza das próteses.

Klemper et al. (1982) avaliaram a eficácia de várias concentrações de hipoclorito de sódio na remoção de depósitos acumulados em próteses parciais e totais comparando-os com higienizadores disponíveis no mercado. Foram utilizados os seguintes higienizadores: Polident, Efferdent, Denalan, hipoclorito de sódio (Clorox) 1\%, Hipoclorito de sódio 5\%, Hipoclorito de sódio 25\%, Hipoclorito de sódio 50\% e água de torneira. Foram seguidas as instruções dos fabricantes para esterilização com os produtos comerciais. Os grupos de 
hipoclorito de sódio e controle foram imersos por 10 minutos. As próteses foram fotografadas e avaliadas por escala de pontos. As soluções de hipoclorito de sódio apresentaram melhores resultados na limpeza das próteses quando comparadas aos produtos comerciais testados. A limpeza ocorreu dentro de 2 a 3 minutos, embora as próteses tenham permanecido em solução por 10 minutos. A solução de hipoclorito de sódio 50\% mostrou-se mais efetiva que os agentes de limpeza avaliados.

Moore et al. (1984), avaliaram e compararam a efetividade de métodos de higienização na limpeza de próteses. $\mathrm{O}$ estudo foi dividido em duas partes, uma laboratorial e outra clínica. O estudo laboratorial testou a capacidade de agentes químicos de limpeza de eliminar Candida albicans sob condições controladas. Os agentes químicos de limpeza testados foram Denalan, Mersene, Polident, Efferdent, Miller's e Clorox/Calgon, avaliados em diluições 1/4, $1 / 2$ e 1 das recomendadas pelos fabricantes. Os resultados desse estudo revelaram que Mersene, Clorox/Calgon e Miller's demonstraram atividade fungicida semelhante em todas as concentrações e tempos testados. A segunda parte do estudo testou a eficácia dos agentes químicos de limpeza em remover e/ou eliminar microrganismos de próteses utilizadas por 10 pacientes. As amostras seguiram os seguintes tratamentos: 1) imersão das próteses em água destilada com o respectivo agente de limpeza por 30 minutos; 2) escovação com escova de cerdas macias, sabão e água corrente por 60 segundos; 3) imersão da prótese em água destilada por 30 minutos (controle). A imersão em Miller's e Kleenite foi o método de higienização mais eficiente, seguido da escovação e imersão em Mersene. Apesar da imersão em Clorox/Calgon ter se mostrado eficiente no estudo laboratorial, não foi efetiva clinicamente. Para melhorar a eficiência in vivo desse agente químico de limpeza, bem como de outros à base de hipoclorito de sódio, os autores sugeriram a adição da substância lauril sulfato de sódio (detergente utilizado para solubilização de proteínas em laboratórios microbiológicos) presente nos materiais Kleenite e Mersene.

Rudd et al. (1984) avaliaram a ação bactericida do hipoclorito de sódio 5,25\% (Clorox) na esterilização de próteses totais e determinaram o tempo necessário de imersão para a obtenção deste efeito. Foram confeccionadas 20 próteses superiores que posteriormente foram cortadas ao meio. Cada parte foi contaminada com os microrganismos Staphylococcus aureus, Bacilus subtilis (forma vegetativa e esporos), Candida albicans, Pseudomonas aeruginosa e Streptococcus (Enterococcus), e, em seguida, submetidas à imersão na solução por 1, 3 e 5 minutos. Os autores concluíram que a imersão por 5 minutos em hipoclorito de sódio 5,25\% (Clorox) proporcionou esterilização contra uma variedade de microrganismos, sendo improvável que imersões ocasionais de 5 minutos afetem o material das próteses. 
Watkinson, McCreight e Wornock (1985), investigaram o efeito do hipoclorito como higienizador de prótese quanto à persistência de Candida albicans na cavidade oral de pacientes com Candidíase Atrófica Crônica. Cinco participantes do estudo foram instruídos a remover suas próteses durante a noite e imergi-las em solução de hipoclorito alcalino (Dentural, McCrathys Ltd.) por 2 semanas. Amostras microbianas foram colhidas do palato e da superfície da prótese. Em 3 dos 5 pacientes, houve reincidência da cepa C. albicans. Segundo os autores, os resultados sugerem que o biofilme das próteses é constantemente recolonizado por leveduras da mucosa e que o hipoclorito de sódio é eficaz contra elas.

Bell et al. (1989) compararam a capacidade biocida do hipoclorito de sódio 5,25\% (diluído 1:10) e dióxido de cloro frente a eliminação de microrganismos patogênicos em amostras de resina acrílica (Accelar 20, Columbia Dental). As amostras foram confeccionadas, esterilizadas e inoculadas com Staphylococcus aureus, Candida albicans ou Escherichia coli na presença de material orgânico. Uma amostra foi usada como controle para cada microrganismo. As amostras foram desinfetadas em dióxido de cloro (Alcide LD, Alcide Corp.) e hipoclorito de sódio (Purex Corp.), diluído 1:10. Como controle empregou-se solução salina. As amostras foram imersas nas soluções por 30 segundos, 1, 2 ou 4 minutos. Após a desinfecção, foram neutralizadas e incubadas por 72 horas para verificar a viabilidade dos organismos. Os resultados mostraram uma diferença entre os produtos testados quando matéria orgânica estava presente. A solução de dióxido de cloro foi efetiva frente a microrganismos em 2 minutos, sendo que o hipoclorito de sódio realizou a desinfecção em 4 minutos. Em dois minutos ambos os desinfetantes foram efetivos na eliminação de Candida albicans.

Basson, Quick e Thomas (1992) avaliaram produtos caseiros não comercializados especificamente para limpeza de prótese, e que poderiam ser efetivos quando utilizados para esta finalidade. Foram confeccionadas placas acrílicas palatinas para 6 indivíduos dentados, as quais foram usadas durante o dia e imersas em soluções higienizadoras durante a noite. As soluções desinfetantes utilizadas foram: 1) Milton 4\% ( $\mathrm{NaOCl} 0,04 \%+\mathrm{NaCl} 0,66 \%) ; 2)$ Milton $1,2 \%(\mathrm{NaOCl} 0,012 \%+\mathrm{NaCl} 0,19 \%) ; 3)$ Vinagre não diluído; 4) Vinagre 50\% diluído; 5) sal ( $\mathrm{NaCl}$ ) 20\%; e 6) água de torneira (controle). Cada produto foi usado por 7 dias consecutivos e, posteriormente, as placas de resina foram removidas, inspecionadas visualmente e processadas laboratorialmente para a contagem de microorganismos viáveis. Todas as soluções testadas resultaram em uma significante redução do número de bactérias quando comparadas ao controle em água. As soluções com maior e menor efetividade foram a solução de Milton e o vinagre não diluído, respectivamente. A imersão noturna das placas em 
uma solução fraca de hipoclorito $(0,012 \%$ e $0,04 \%)$ resultou em significante redução do número de bactérias e de biofilme.

Webb et al. (1995) avaliaram a eficácia in vitro do hipoclorito de sódio na esterilização de próteses acrílicas e na adesão de espécies de Candida em superfícies orais. Foi utilizada solução antibacteriana de Milton (Proctor \& Gamble Austrália Pty. Ltd), sendo avaliado o crescimento de Candida na presença ou ausência do hipoclorito. O hipoclorito de sódio reduziu a adesão de várias espécies de Candida. Concluiu-se que o hipoclorito na concentração inibitória mínima combate a adesão de espécies de Candida, mas não afetam suas características patogênicas. O hipoclorito de sódio pode funcionar como efetivo agente antifúngico, quando usado para a imersão de próteses em caso de Candidíase Atrófica Crônica.

Kulak et al. (1997) avaliaram o efeito da escovação e de agentes químicos sobre a superfície de próteses. Cinco próteses totais superiores foram coletadas e imediatamente transferidas para solução de formalina a 10\%. Utilizou-se um disco de carborundum para preparar 8 amostras de $1 \mathrm{~cm}^{2}$ a partir de cada prótese. Uma amostra foi deixada sem tratamento (controle) e outra, processada e polida para ser utilizada como comparação adicional. Seis amostras de cada prótese foram imersas durante o período noturno em soluções efervescentes (Corega - Stafford - Miller Ltd.; Dentipur - Helago - Pharma D - 5300; Fittydent - Mag. Hoeveler e Co.), hipoclorito de sódio a 5\%, Savlon (Zeneca Abdi-Irahim Ilaç Tic.) e Ipanol (Procter e Gamble). Uma das amostras foi submetida à escovação com uma pasta específica para prótese (Ipana - Procter e Gamble) por 30 segundos. Observou-se que todos os tratamentos reduziram a porcentagem de área da amostra coberta por material estranho quando comparados com o controle. Os resultados mostraram que as soluções de hipoclorito de sódio $5 \%$ e Savlon foram as mais efetivas na remoção de contaminantes. Os autores concluíram que a imersão da prótese durante a noite em solução de Savlon foi o mais efetivo de todos os procedimentos, que a higienização eficiente da prótese é importante para manutenção da saúde oral dos pacientes e que a limpeza mecânica (escovação da prótese) provavelmente não é efetiva na remoção de microrganismos, especialmente de endentações na superfície da prótese.

Shay (2000) realizou um estudo para avaliar os métodos de higiene utilizados pelos usuários de próteses totais e compará-los. O autor afirmou que a solução doméstica mais comumente utilizada era o alvejante (hipoclorito de sódio) diluído 1:10 em água de torneira. O autor concluiu que a escovação foi inadequada para o controle do biofilme, e que a imersão 
em solução de hipoclorito de sódio diluído ou em produto efervescente comercial consistiu em método efetivo de limpeza.

Garcia Junior (2002) avaliou a eficácia de hipoclorito de sódio 1\% (Biodinâmica Química e Farmacêutica Ltda.), hipoclorito de sódio 2\% (Biopharma) e glutaraldeído 2\% (Cidex, Johnson \& Johnson Produtos profissionais Ltda.), frente aos microrganismos Staphylococcus aureus, Pseudomonas aeruginosa, Enterococcus faecalis, Streptococcus mutans e Candida albicans, na desinfecção da superfície externa e interna de uma resina acrílica termopolimerizável (Lucitone 550, Dentisply). Corpos-de-prova foram imersos nas soluções por 5, 10 e 15 minutos. Os resultados mostraram que 10 minutos de imersão foram adequados para a desinfecção da superfície externa da resina acrílica, sendo que a rugosidade não teve influência. A desinfecção por 15 minutos com hipoclorito de sódio $1 \%$ e glutaraldeído $2 \%$ foram eficazes frente a maioria dos microrganismos presentes internamente na resina acrílica.

Pavarina et al. (2003a) analisaram a eficácia de um protocolo para controle de infecção, limpeza e desinfecção de próteses removíveis. Foram selecionados 32 pacientes usuários de próteses totais ou próteses parciais removíveis com crescimento microbiano comprovado inicialmente. As próteses foram distribuídas em 4 grupos e colocadas por 10 minutos em uma das seguintes soluções de imersão: gluconato de clorexidina $4 \%$, hipoclorito de sódio $1 \%$, solução de Biocide $0,48 \%$ e solução de Amosan 3,78\% (peróxido alcalino). Após os procedimentos de desinfecção, as próteses foram imersas em água estéril por 3 minutos para eliminação de resíduos das soluções desinfetantes, foram realizados esfregaços e as amostras incubadas novamente. A presença de crescimento microbiano foi determinado após 24 horas. Os resultados obtidos mostraram que todas as soluções de imersão reduziram o crescimento de microrganismos, exceto Biocide, que não foi efetivo. Os autores concluíram que o protocolo analisado é um método viável para prevenir contaminação cruzada.

Barnabé et al. (2004) avaliaram a efetividade da escovação (sabão de coco) associada à imersão diária em hipoclorito $0,05 \%$, no controle da Candidíase Atrófica Crônica e redução de Candida sp. e Streptococcus mutans. Sessenta indivíduos usuários de próteses totais superiores foram distribuídos em dois grupos de 30 pacientes. No primeiro grupo, instituiu-se escovação da prótese com sabão de coco, seguida da imersão em água filtrada uma vez ao dia (contole), e no segundo grupo, escovação seguida de imersão da prótese em solução de hipoclorito $0,05 \%$, uma vez ao dia, ambos por 15 dias. Foram realizadas análises microbiológicas e análises das áreas de inflamação do palato conforme a classificação de Newton. Os resultados indicaram redução significante das áreas de inflamação do palato para 
o grupo que utilizou hipoclororito. Neste mesmo grupo observou-se uma redução na quantidade de Candida sp. e Streptococcus mutans; no entanto, esta redução não foi significante. Concluiu-se que a os agentes químicos reduzem a patogenicidade do biofilme e que o uso do sabão de coco associado ao hipoclorito promoveu a remoção de manchas das próteses.

\subsection{Solução à base de Riccinus comunis}

O óleo de mamona, conhecido no Brasil como óleo de rícino e internacionalmente como "castor oil”, é extraído das sementes da mamona, um arbusto típico de climas tropicais pertencente à classe Dicotiledônea, ordem Geraneaces, família Euforbaceas, gênero Ricinus, espécie Communis. A existência de um grande número de variedades dessa planta, encontradas tanto no continente africano como no asiático, impossibilita qualquer tentativa de se estabelecer sua origem efetiva. Sementes encontradas em túmulos mostram que a mamona já era utilizada pelos egípcios há pelo menos 4 mil anos. Na antiga Grécia, alguns filósofos mencionaram em seus escritos o emprego do óleo de mamona no Egito para iluminação e na produção de ungüentos. A planta foi trazida ao Brasil pelos portugueses, com a finalidade de utilizar seu óleo para iluminação e lubrificação de eixos de carroças. O clima tropical facilitou o seu alastramento. Cerca de $90 \%$ do óleo é composto por triglicerídio, principalmente da ricinoleína, que é o componente do ácido ricinoléico, cuja fórmula molecular é $\mathrm{C}_{17} \mathrm{H}_{32} \mathrm{OHCOOH}$, o que confere ao óleo suas características singulares, possibilitando ampla gama de utilização industrial, tornando a cultura da mamoneira importante potencial econômico e estratégico ao País.

As aplicações do óleo são inúmeras podendo ser empregado em vários processos industriais, na fabricação de tintas, protetores e isolantes (depois de desidratado), lubrificantes, cosméticos, drogas farmacêuticas, bem como a fabricação de corantes, anilinas, desinfetantes, germicidas, óleos lubrificantes de baixa temperatura, colas e aderentes, base para fungicidas e inseticidas, tintas de impressão e vernizes, além de nylon e matéria plástica, em que tem bastante importância. Transformado em plástico, sob a ação de reatores nucleares, adquire a resistência de aço, mantendo a leveza da matéria plástica.

Essa diversificação de aplicações do óleo de mamona está evidentemente relacionada com sua composição química, predominando na mistura os glicerídeos que contêm o grupo ricinoléico. O ácido ricinoléico possui uma estrutura composta por 18 átomos de carbono e difere dos outros ácidos graxos por localizar uma hidroxila no carbono-12 de sua cadeia, e por 
apresentar uma dupla ligação cis entre carbonos 9 e 10. O óleo da mamona é predominantemente composto pela molécula do ácido ricinoleico, possuindo estrutura química semelhante aos ácidos graxos essenciais humanos como o ácido linoleico e o ácido alfa-hidroxi-nervônico, presente no sistema nervoso central humano. Possui um grande potencial oleoquímico, podendo garantir o fornecimento de polióis e pré-polímeros a partir de ácidos graxos em larga escala. Devido à sua composição, de 81 a $96 \%$ de triglicerídeo do ácido ricinoléico, pode ser considerada como um poliol natural por conter três radicais hidroxilas passíveis de serem utilizados na síntese de poliuretanas (PASCON,1999).

O ricínio é uma potente toxina protéica que age especificamente inativando os ribossomos, promovendo a morte celular por inativação da síntese protéica.

Tais características estruturais e funcionais não somente conferem ao óleo de mamona algumas de suas propriedades intrínsecas, como a elevada viscosidade ou a sua miscibilidade em álcool, mas também ativam a molécula tornando-a acessível a muitas reações químicas.

A partir dos estudos sobre biocompatibilidade na área de ortopedia (BELOTI et al., 2003; HIRAKI et al., 2001; IGNÁCIO et al., 2002; OHARA et al., 1995), os pesquisadores da área de Odontologia observaram a possibilidade de utilizar a mamona (Ricinus communis) para reconstrução e reparo de defeitos ósseos, que promovam leitos viáveis para receber implantes, pinos, redes metálicas, levantamento do seio maxilar e preenchimento de alvéolos (BARROS et al., 2001; CALIXTO et al., 2001; CARVALHO et al, 1997; COSTA, 1997; MANTESSO et al., 2000).

No campo da Endodontia foi desenvolvido um detergente à base do óleo de mamona para ser utilizado como solução irrigante de canais radiculares necróticos com atividade antimicrobiana similar à do hipoclorito de sódio a 0,5\% (FERREIRA et al., 1999; FERREIRA et al., 2002). Este detergente tem ação contra bactérias gram-positivas e leveduras (ITO et al., 1999), ação antiinflamatória (BARROS et al., 2001), é biocompatível com os tecidos periapicais (MANTESSO et al., 2000), possui capacidade de aumentar a permeabilidade dentinária (PÉCORA et al., 2000) e promover a remoção da smear layer semelhante ao EDTA 17\% (TEIXEIRA et al., 2001).

Ito et al. (1999) estudaram a diluição máxima inibitória dos detergentes derivados do óleo ricinoléico, subproduto da mamona, para diferentes tipos de cocos gram-positivos, bacilos gram-negativos e leveduras. Os resultados mostraram que o detergente derivado da mamona não tem ação sobre gram-negativos in vitro, mas apresenta atividade antimicrobiana contra gram-positivos e leveduras, podendo ser utilizado como anti-séptico ou desinfetante. 
Ferreira et al. (1999) compararam a atividade antimicrobiana do gel de papaína a 0,4; detergente derivado da mamona a 3,3\% e hipoclorito de sódio a $0,5 \%$ em dentes com necrose pulpar. Foram realizadas coletas do material no interior dos canais radiculares antes, imediatamente após e depois de 72 horas da instrumentação com as substâncias avaliadas. Os resultados mostraram que o detergente a 3,3\% e o hipoclorito de sódio a $0,5 \%$ apresentaram atividade antimicrobiana similar na redução do número dos anaeróbicos, S. mutans e Streptococci, porém o gel de papaína a $0,4 \%$ mostrou baixa atividade sobre esses microrganismos. Os autores concluíram que a solução de mamona a 3,3\% e o hipoclorito de sódio a $0,5 \%$ são efetivos como agentes antimicrobianos podendo ser empregados no tratamento de canais radiculares com polpa necrosada.

Sampaio (1999) avaliou, por meio da microscopia eletrônica de varredura, a capacidade de limpeza de diferentes detergentes e do quelante EDTA em superfícies radiculares submetidas à raspagem e aplainamento periodontal. Os melhores resultados foram obtidos com o EDTA, seguido pelo Plax e o derivado da mamona (Perioquil).

Pécora et al. (2000) observaram o efeito do detergente derivado da mamona e do gel de papaína sobre a permeabilidade dentinária radicular e concluíram que os detergentes derivado da mamona a 3,3\%, o gel de papaína a $0,4 \%$ e a solução de hipoclorito de sódio a 0,5\% promoveram um aumento da permeabilidade dentinária.

Ferreira et al. (2002) avaliaram a atividade antimicrobiana de substâncias utilizadas como agentes antimicrobianos (solução hidróxido de cálcio, PMCC, digluconato de clorexidina e um detergente obtido a partir do óleo de mamona) em bactérias anaeróbicas (Fusobacterium nucleatum, Prevotella nigrescens, Clostridium perfringens e Bacterioides fragilis) in vitro. Todos os agentes apresentaram ação antimicrobiana, com melhor desempenho do Digluconato de Clorexidina, seguido pelo detergente à base de óleo de mamona, pelo PMCC e pelo hidróxido de cálcio. Os resultados obtidos pelos espécimes irrigados com detergente de mamona a 3,3\% provavelmente ocorreram devido à sua baixa tensão superficial, o que por sua vez permite uma capacidade de umectar toda superfície de contato do canal radicular. Após a umectação, ocorre o fenômeno de adsorção, que é a união da parte hidrófoba, que também é lipófila, à gordura e, a parte hidrófila liga-se à água. Sendo assim, a cadeia hidrocarbônica funciona como uma parte que tem em uma das extremidades a gordura e na outra a água, o que faz com que a superfície fique livre de contaminação gordurosa (oleosa) e protegida pelas moléculas de detergente fixada a ela (PÉCORA et al., 1999). 
Siqueira (2005) realizou um trabalho para comparar in vivo o efeito antimicrobiano do hipoclorito de sódio $1 \%$, da clorexidina a $2 \%$ e do detergente à base de mamona $10 \%$ (Endoquil) na irrigação de canais radiculares de 18 dentes anteriores superiores humanos com necrose pulpar e lesão periapical visível radiograficamente. Baseado na análise dos resultados concluiu-se que todas as substâncias utilizadas promoveram uma redução no número de bactérias. 


\section{Materiais constituintes da prótese total}

\subsection{Resina acrílica}

A resina acrílica é um polímero utilizado rotineiramente para base de próteses totais, na realidade, um polímero, que se origina a partir da adição de um líquido (monômero) ao pó (polímero), de modo que este processo não altere a composição química do material durante a sua polimerização que pode ser desencadeada ou iniciada por calor, luz, ou agentes químicos (ANUSAVICE, 1996; CRAIG e WARD, 1997). Na confecção de próteses totais comumente utiliza-se a resina acrílica ativada termicamente. Neste caso, o agente de calor necessário para desencadear o processo de polimerização é proveniente do aquecimento do material em água, por calor seco ou ainda, por meio de energia de microondas

A versatilidade da resina acrílica deve-se a características como biocompatibilidade, ausência de sabor e odor, propriedades térmicas satisfatórias, estabilidade dimensional, boa capacidade de polimento, aparência natural (estética) e, simplicidade de técnica (ANUSAVICE, 1996). As características das resinas acrílicas são estudadas por meio de parâmetros propostos pela Associação Dental Americana, que incluem: estabilidade dimensional, solubilidade, grau de dureza, resistência à flexão, rugosidade, alteração de cor, entre outros (PEYTON, 1975).

Um aspecto de relevância a ser enfocado nos estudo da resina acrílica é a propriedade mecânica de resistência à flexão, que está diretamente relacionada à resistência do material diante de ocorrências como fraturas por queda do aparelho ou, por fadiga do material durante o uso. A estabilidade de cor também tem grande importância devido às preocupações com a estética. A propriedade de dureza está relacionada com ductibilidade, limite de proporcionalidade e resistência. A rugosidade está intimamente ligada à penetração e colonização por microorganismos.

Miner (1973) examinou materiais de base de prótese total (polimetil-metacrilato, vulcanite e ouro) por meio de microscopia eletrônica. Foram utilizadas amostras de bases de próteses utilizadas por diferentes pacientes e também amostras confeccionadas a partir da moldagem do arco maxilar de um dos pacientes. As amostras observadas foram capazes de promover o acúmulo de debris e microrganismos devido à presença de porosidades e irregularidades, sendo que as amostras de polimetil-metacrilato apresentaram-se mais rugosas, as de vulcanite absorveram mais fluidos e as de ouro não absorveram fluidos orais e mostraram-se com superfície mais regular. 
Roth e Fleming (1980) avaliaram a efetividade de higienizadores comerciais e caseiros em próteses. A primeira parte do trabalho consistiu em um questionário enviado a 75 pacientes portadores de próteses removíveis abordando materiais, métodos e freqüência de higiene, além da satisfação com os mesmos. A maioria dos entrevistados utilizava higienizadores comerciais. Na segunda parte, foram testados produtos de imersão para verificação de mudanças na cor e textura em amostras de resina acrílica de base de próteses, por meio de exames macroscópicos, encontrando-se mudanças de textura para todos os produtos testados. Na terceira parte, foram testados os efeitos da escovação, utilizando-se diversos tipos de escova, dentifrícios, sabão e soda. Foram verificados, macroscopicamente, riscos nas superfícies das amostras mais acentuados para as escovas dentais do que para escovas de prótese. O sabão provocou menores riscos, enquanto os dentifrícios produziram riscos moderados. Os achados microscópicos confirmaram os resultados macroscópicos.

Crawford, Newton e Yemm (1985) avaliaram pacientes com dentaduras clareadas durante um período de 12 meses, durante o qual os pacientes foram cuidadosamente questionados sobre os materiais por eles utilizados e o procedimento exato adotado para limpeza de seus aparelhos. Dos 34 pacientes entrevistados, a maioria (28) estava usando um higienizador à base de peróxido alcalino (Steradent $\left.{ }^{\circledR}\right)$, mas em temperaturas extremamente altas. Concomitantemente, outro levantamento de pacientes mostrou que muitos estavam usando o mesmo higienizador, sem evidências de perda de cor da dentadura, mesmo em períodos de tempo prolongado. Porém, esses pacientes seguiram mais adequadamente as recomendações do fabricante quanto ao procedimento (água à $50^{\circ} \mathrm{C}$ ).

Robinson, McCabe e Storer (1985) investigaram o branqueamento da resina acrílica por meio de estudos da microestrutura de próteses branqueadas e por testes laboratoriais, onde resinas termopolimerizáveis (Metocryl e SR 3/60) e autopolimerizável (De Trey Rapid Repair) foram expostas a higienizador de prótese à base de peróxido alcalino (Steradent), e então submetido à transmissão de luz. Uma das resinas termopolimerizáveis (Metocryl) foi submetida ao teste mecânico de flexão. Nenhuma das resinas exibiu o branqueamento observável nas amostras clínicas, e não ocorreu mudança nas propriedades mecânicas. Os autores concluíram que próteses severamente branqueadas mostram claras evidências de serem atacadas por agentes externos. $O$ tratamento de materiais termopolimerizados equivalente a 1 ano por meio de uso diário de peróxido alcalino não causou branqueamento significante nem afetou as propriedades mecânicas da resina termopolimerizável Metocryl.

Crawford et al. (1986) realizaram testes em amostras de resina acrílica simulando os procedimentos de limpeza usados por pacientes com dentaduras clareadas. O agente 
higienizador utilizado foi o Steradent ${ }^{\circledR}$ com água em 3 temperaturas (indicada pelo fabricante, $100^{\circ} \mathrm{C}$ e gelada). As imersões tiveram duração de 30 minutos ou 8 horas. As amostras foram examinadas por 100 dias quanto à sua aparência visual, características superficiais, transmissão de luz e resistência à flexão transversal. As amostras imersas em água fervendo (com ou sem higienizador) apresentaram-se alteradas, não somente em relação à cor, mas houve também perda de translucidez, perda da camada superficial e redução da resistência. Naquelas amostras que foram seguidas as instruções do fabricante, não ocorreram alterações. Como conclusão principal, os autores afirmam que o clareamento das bases de dentaduras de resina acrilica é, na realidade, um efeito de opacificação superficial produzido principalmente pelo uso de água fervendo e não pelo higienizador em si.

Crawford, Newton e Yemm (1987) avaliaram os materiais e métodos utilizados pelos pacientes com dentaduras clareadas por meio da microscopia eletrônica de varredura. Foram retiradas amostras destas dentaduras e realizados testes para determinar quando o clareamento da resina acrílica havia sido puramente um fenômeno de superfície ou quando envolveu uma espessura profunda do aparelho. O exame indicou uma penetração substancial do processo de clareamento e uma decomposição da camada superficial originando uma aparência rugosa e opaca. No grupo das dentaduras clareadas, a maioria dos pacientes fazia uso de um higienizador à base de peróxido alcalino e todos usavam água muito quente.

Robinson, McCabe e Storer (1987) realizaram uma série de testes para avaliar resinas acrílicas (termopolimerizável e autopolimerizável) submetidas a tratamentos higienizadores, incluindo, além do tratamento com higienizador de prótese, a exposição em altas temperaturas $\left(95^{\circ} \mathrm{C}\right)$ e a vapor de solvente (acetona). Os higienizadores utilizados nos testes foram: peróxido alcalino (Steradent - Reckitt Household Toiletry Products) e hipoclorito doméstico (Domestos - Lever Bros. Ltd.). Concluiu-se que ambos os materiais foram branqueados pelas soluções em altas temperaturas (hipoclorito, água e peróxido alcalino). A exposição a vapor de solvente antes da imersão em algumas das soluções aumentou o efeito de branqueamento. Amostras branqueadas sofreram redução da resistência a flexão.

Arab, Newton e Lioyd (1988) também realizaram testes laboratoriais em amostras de resina acrílica utilizando agentes higienizadores de próteses totais em temperaturas mais altas do que aquelas recomendadas pelos fabricantes. As amostras foram imersas diariamente em agentes higienizadores por 30 minutos utilizando temperaturas variadas: $50^{\circ} \mathrm{C}$ (recomendada pelo fabricante), $60^{\circ} \mathrm{C}, 70^{\circ} \mathrm{C}, 80^{\circ} \mathrm{C}, 90^{\circ} \mathrm{C}$ e $100^{\circ} \mathrm{C}$. O período experimental durou 100 dias. Os autores avaliaram a aparência visual, as características superficiais, transmissão de luz e resistência transversal. Os resultados mostraram que a uma temperatura de $80^{\circ} \mathrm{C}$ ou mais, as 
amostras apresentaram um aspecto de clareamento e também alterações nas propriedades físicas como decomposição da camada superficial, redução na transmissão da luz e resistência transversal, bem como aumento na dureza superficial.

Arab, Newton e Lloyd (1989) realizaram testes laboratoriais que simularam os procedimentos de higienização dos pacientes com próteses branqueadas, em amostras de resina acrílica com alto e baixo nível de monômero residual. Foram utilizadas as soluções: 1) Steradent dissolvido em $150 \mathrm{ml}$ de água a $50^{\circ} \mathrm{C}$ como recomendado pelo fabricante; 2) água a $\left.50^{\circ} \mathrm{C} ; 3\right)$ água fervente a $100^{\circ} \mathrm{C}$ com o higienizador e 4) água fervente. Amostras controles foram armazenadas em água a temperatura ambiente $\left(18^{\circ} \mathrm{C}\right)$ sem adição de higienizador. Foram realizadas imersões de 30 minutos diários, realizadas por 100 dias. Para quantificar a transmissão de luz através da amostra foi utilizado um espectrofotômetro. Concluiu-se que um elevado nível de monômero residual não é o principal fator do branqueamento do acrílico das próteses, mas sim a alta temperatura da água, independentemente da presença do higienizador.

McNeme, Von Gontem e Woolsey (1991), determinaram os efeitos de agentes desinfetantes químicos em resinas acrílicas fotoativada (Triad VLC - Dentsply), termoativada (CH Lucitone - Dentsply) e autopolimerizável (Truliner - Harry J. Bosworth Co.). Os desinfetantes testados foram hipoclorito de sódio 1\% (Clorox Corp.), Exspor (Alcide Corp.), Cidex 2\% (Johnson \& Johnson) e Wescodyne-D (West Chemical Products). As mudanças de cor foram avaliadas em intervalos de tempo (15, 30, 45 e 60 minutos; 2, 4, 8, 16, 24, 48, 72 horas). Uma única amostra da resina $\mathrm{CH}$ Lucitone foi imersa em hipoclorito de sódio 5,25\% por 72 horas. As amostras foram classificadas pelos níveis de descoloração numa escala de pouco, moderado e severo. Nenhuma mudança de cor observável foi vista antes de 2 horas de imersão. Os agentes hipoclorito de sódio a $1 \%$ e Cidex $2 \%$ produziram uma mínima descoloração das resinas acrílicas e o Wescodyne-D produziu a maior descoloração. A resina $\mathrm{CH}$ Lucitone foi a que apresentou a menor mudança de cor, seguida pela Triad VLC e Truliner. Os autores concluíram que, se os tempos de desinfecção recomendados pelos fabricantes forem seguidos, não ocorrerá mudança de cor das próteses.

Buyukilmaz e Ruyter (1994) avaliaram quantitativamente a descoloração de materiais para base de prótese (um fotopolimerizável, três termopolimerizáveis e três autopolimerizáveis) após a exposição a chá, café, água destilada $\left(50^{\circ} \mathrm{C}\right)$ sem exposição à luz, e água e luz solar artificial. As amostras permaneceram imersas em chá e café por 96 horas a $50^{\circ} \mathrm{C} \pm 1{ }^{\circ} \mathrm{C}$, e em seguida foram limpas por lavagem com sabão; escovação com sabão e escovação com pasta de dentes. Amostras manchadas e limpas foram armazenadas em 
soluções de café e chá por mais 1000 horas a $50^{\circ} \mathrm{C} \pm 1{ }^{\circ} \mathrm{C}$. Em seguida, as amostras foram limpas e ambos os lados das amostras foram desgastados. Três amostras de cada material foram colocadas em água destilada por 1440 horas a $50^{\circ} \mathrm{C} \pm 1{ }^{\circ} \mathrm{C}$. Três amostras de cada material foram usadas para estudar mudanças na aparência após 540 horas de exposição à luz solar artificial e água a $37^{\circ} \mathrm{C} \pm 5^{\circ} \mathrm{C}$. Medidas de cor foram feitas usando espectrofotometria de reflectância (sistema CIELab) antes e depois das amostras terem sido expostas às soluções de manchamento, água (com e sem luz artificial), após a limpeza das amostras, e após o desgaste. Concluíram que café e chá mancharam o material superficialmente, e que a escovação com pasta de dente e o desgaste das superfícies das amostras reduziu a descoloração para um nível aceitável. Todos os materiais foram relativamente estáveis quanto à descoloração durante as imersões por longos períodos em água destilada a $50^{\circ} \mathrm{C} \pm 1{ }^{\circ} \mathrm{C}$. Quando expostos à luz solar artificial e água, os materiais comportaram-se diferentemente quanto à estabilidade de cor.

Liberman et al. (1995) estudaram as condições laboratoriais mais favoráveis para experimentos de avaliação de mudança de cor de resinas acrílicas. Discos foram preparados a partir de dez polímeros para base de prótese (Fastcure - pink, Fastcure - clear, Meadway, Minacryl, QC-20, SR Ivocap, SR 3/60, Trevalon, Trevalon C, Trevalon HI). Três destas resinas (SR Ivocap, Minacryl e Fastcure) foram selecionadas para determinação apropriada da cor do plano de fundo para a realização de medidas quantitativas de mudanças de cor. Nove planos de fundo foram utilizados e foi determinado o uso do plano de fundo branco. Metade de cada amostra foi exposta por 24 horas a uma lâmpada simuladora de luz solar. A cor das amostras foi medida no sistema CIE L*a*b* usando um colorímetro fotoelétrico (Minolta CR-221 Chroma Meter). As medidas foram realizadas contra o plano de fundo branco. Mudanças significantes nos valores de $b^{*}$ e $E^{*}$ foram observados após a exposição à luz. Os dados objetivos foram comparados com os resultados de avaliações subjetivas e foi demonstrado que uma mudança em $b^{*}$ de 1,5 unidades foi perceptível subjetivamente pelo olho humano em $100 \%$ dos casos.

May et al. (1996) determinaram a estabilidade de cor após envelhecimento acelerado em 5 materiais para base de prótese termopolimerizáveis convencionais, 2 materiais de termopolimerização rápida e um material de microondas (Lucitone, Hy-pro-Dentsply International; Accelar 20 Adv. Form.-Modern Materials; Lucitone 199-Dentsply International; Ebony light-Hygenic Corp.; Lucitone, CH-Dentsply International; Lucitone, TruTone-Dentsply International; Acron-G-C Dental Industrial Corp.) processados por energia de microondas (5 minutos a alta temperatura). A mudança de cor $(\Delta \mathrm{E})$ foi medida com um 
instrumento Chroma Meter II, antes e após o envelhecimento acelerado de 300, 600 e 900 horas. Todos os materiais polimerizados em microondas exibiram mudanças de cor.

Ünlü, Altay e Sahmali (1996) analisaram o efeito de higienizadores químicos em resinas acrílicas termopolimerizáveis e autopolimerizáveis. Foram selecionadas 3 resinas acrílicas termopolimerizáveis (Rodex - Rodex, QC-20 - De Trey e Meliodent heat - Bayer) e 3 autopolimerizáveis (Meliodent auto - Bayer, Acralite - Acralite e Orthodontic - Dentarium). Foram utilizados 4 higienizadores químicos: Polident (Block Drug), Efferdent (WarnerLambert), Blend-A-Dent (Wick Pharma) e Corega (Stafford-Miller Limited Hatfield). As amostras foram imersas por 240 horas, sendo que as soluções foram trocadas a cada 8 horas, simulando 30 noites de imersão.Um reflectômetro foi utilizado para medir os valores de cor das amostras. O higienizador Corega provocou o maior efeito de branqueamento nas resinas, sendo que o Polident causou o menor branqueamento. A resina acrílica termopolimerizável QC-20 apresentou um branqueamento mínimo, enquanto a maior mudança foi vista com as resinas acrílicas autopolimerizáveis.

Ma, Johnson e Gordon (1997) avaliaram a ação de desinfetantes químicos sobre a textura superficial e a cor de resinas acrílicas. Cinco soluções desinfetantes (Clorox - Clorox; Banicide - Pascal Comp. Inc.; Cidex-7 - Surgikos; Biocide - Biotrol International; Multicide - Biotrol International) em resinas autopolimerizáveis (Dentsplay reline material - Dentsply; Hygenic HyFlo - The Hygenic Corp.; Hygenic Perm - The Hygenic Corp), termopolimerizável (Lucitone 199 - Dentsply) e fotopolimerizável (Triad VLC reline resin Dentsply) foram analisados em quatro tempos de imersão (10 minutos, 30 minutos, 24 horas e 7 dias). Foi utilizado um colorímetro para análise da cor. Diferenças estatísticas foram demonstradas entre desinfetantes e resinas tanto para cor, como para textura superficial; porém, essa mudança foi clinicamente insignificante. O desinfetante Multicide (Fenólico) não deve ser usado nas resinas estudadas, devido aos danos superficiais causados em todas as resinas após 30 minutos de imersão. Quando comparado com outros desinfetantes, o Biocide (desinfetante a base de iodo) foi o que demonstrou mudança de cor significante nas resinas acrílicas, exceto para Lucitone 199. Com o uso do desinfetante Biocide todas as resinas tornaram-se mais escuras. Somente a Lucitone 199 não exibiu mudança de cor após 7 dias de imersão. A imersão no desinfetante Clorox (hipoclorito de sódio a 5,25\%) por 7 dias deixou as resinas mais claras, exceto para Triad VCL (fotopolimerizável).

Polyzois et al. (1997) avaliaram os efeitos de soluções desinfetantes na cor de resinas acrílicas (termopolimerizável, fotoativada e autopolimerizável). Foram utilizados 4 desinfetantes (Klinex - hipoclorito de sódio diluído 1:10 com água destilada - 0,525\%; Cidex 
7 - glutaraldeído alcalino 2\%; Hibitane - Clorexidina 5\% diluída 1:10 em água destilada 0,5\%; e Cabadol - fenol) e 3 resinas (Paladon 65 - termopolimerizável; Triad - fotoativada; e ProBase Cold - autopolimerizável). As amostras foram imersas nos desinfetantes por 10 minutos, 10 horas e 7 dias. Amostras adicionais de cada resina testada foram colocadas em água destilada como controle. Medidas de cor foram feitas antes das imersões e nos intervalos de tempo utilizando-se um colorímetro. As resinas ProBase Cold e Triad mostraram os maiores valores de alteração de cor quando imersas no desinfetante Cabadol após 7 dias. A resina termopolimerizável (Paladon 65) mostrou a melhor estabilidade de cor após imersão nos desinfetantes testados. Concluíram que, se os tempos de desinfecção recomendados forem seguidos, não ocorrerão mudanças de cor visíveis nas resinas acrílicas.

Radford et al. (1998) avaliaram a aderência in vitro de Candida albicans em uma resina termicamente ativada (Trevalon Clear) e em dois materiais resilientes (Molloplast B e Novus) variando a rugosidade de superfície e o efeito da presença de saliva não estimulada. As superfícies foram preparadas usando instrumentos rotatórios apropriados para produzir ou não rugosidades. Maior adesão foi observada nas superfícies rugosas do que nas polidas, assim como a adesão foi maior nos materiais resilientes quando comparados com a resina acrílica. A presença de saliva reduziu a adesão em todos os materiais. Os autores concluíram que a rugosidade da superfície promove adesão de Candida albicans, entretanto a saliva reduz a adesão e diminui o efeito da rugosidade da superfície e a energia livre da superfície dos materiais.

Lee et al. (2002) estudaram três fatores em relação às resinas acrílicas autopolimerizáveis: temperatura, pressão e ambiente em que a polimerização foi realizada. As propriedades de microdureza e quantidade de monômero residual foram analisadas. A temperatura durante a polimerização foi o fator dominante para o aumento da microdureza da superfície das resinas, enquanto a polimerização em água foi o fator chave na redução da quantidade de monômero residual. A pressão não apresentou influência significativa nas propriedades testadas.

Yannikakis, Zissis e Polyzois (2002) investigaram o efeito da energia de microondas na porosidade de duas resinas acrílicas termopolimerizáveis: Paladon 65 (convencional) e Acron MC (microondas). Ambas foram divididas em grupos, que foram polimerizados em ciclos curtos e longos em microondas. O grupo controle teve seus espécimes polimerizados do modo convencional com a resina Paladon 65. Amostras em espessuras de três e seis milímetros foram confeccionadas. A análise da porosidade foi feita em microscopia com aumento de 100 vezes, por meio do cálculo da área dos poros com um planímetro e pelo 
número e distribuição desses poros. O grupo controle não apresentou nenhuma porosidade. Os grupos da resina convencional polimerizada em microondas apresentaram grande porosidade, enquanto os grupos da resina Acron MC tiveram poros pequenos, sem significância clínica. $\mathrm{O}$ fato de o ciclo ser longo ou curto não interferiu nos níveis de porosidade. Os espécimes mais espessos apresentaram-se mais porosos.

Lai et al. (2003) estudaram a morfologia e as propriedades, dentre as quais a resistência à flexão, de resinas acrílicas (Optilon - 399) para dentaduras polimerizadas sob energia de microondas e pelo modo convencional (sob altas temperaturas em água). Foram confeccionados 50 corpos-de-prova ( $65 \times 15$ x $10 \mathrm{~mm}$ ). O teste foi feito levando os corposde-prova à Máquina Universal de Ensaios (modelo 810) e submetidos à flexão em três pontos. Foi observada uma diferença significante na temperatura de polimerização quando comparados estes dois métodos de processamento. Houve pequenas, mas significantes diferenças estatísticas na morfologia e nas propriedades de flexão. A polimerização convencional a $70^{\circ} \mathrm{C}$ em água obteve corpos-de-provas mais resistentes à flexão do que a polimerização sob energia de microondas. No entanto, o processamento em microondas tem bom potencial, uma vez que economiza tempo na execução das dentaduras.

Pavarina et al. (2003b) avaliaram o efeito dos desinfetantes químicos (gluconato de clorexidina a $4 \%$, hipoclorito de sódio a $1 \%$ e perborato de sódio a $3,78 \%$ ) na resistência transversal de resinas acrílicas para base de dentadura. Foram confeccionados 50 corpos-deprova para cada resina (Lucitone 550 e QC-20) de 2,5 x 10 × $65 \mathrm{~mm}$. Estes foram acondicionados em água destilada a $37^{\circ} \mathrm{C}$ por 2 horas e divididos aleatoriamente em grupos: submetidos ao teste depois de armazenados em água a $37^{\circ} \mathrm{C}$ por 2 horas; e submetidos a desinfecção por duas vezes, a primeira em clorexidina por 1 minuto e a segunda imersos por 10 minutos nas soluções de gluconato de clorexidina ou hipoclorito de sódio ou perborato de sódio, simulando a situação em que a prótese chega ao laboratório e retorna ao paciente. Depois da desinfecção, os corpos-de-prova foram imersos em água por três minutos e submetidos ao teste de flexão transversal na Máquina Universal de Ensaios. Não houve nenhum efeito significativo quanto à resistência nos corpos-de-prova submetidos à desinfecção nessas três soluções. O teste demonstrou que a resina QC-20 tem menos resistência que a resina Lucitone 550.

Compagnoni et al. (2004) avaliaram os efeitos de diferentes ciclos de polimerização em microondas na porosidade de resinas acrílicas específicas para este método de polimerização. As resinas Onda Cryl e Clássico (controle - convencional) foram utilizadas. Trinta e dois corpos-de-prova foram distribuídos em três grupos experimentais: A- 500 w, 3 
minutos; B- $90 \mathrm{w}, 13$ minutos $+500 \mathrm{w}, 90$ segundos; C- $320 \mathrm{w}, 3$ minutos $+0 \mathrm{w}, 4$ minutos + $720 \mathrm{w}, 3$ minutos. $\mathrm{O}$ grupo controle foi polimerizado em água a $74^{\circ} \mathrm{C}$ por 9 horas. A porosidade foi medida pelo volume dos corpos-de-prova antes e após sua imersão em água. Foi concluído que a resina acrílica específica para uso em microondas não foi afetada pelos diferentes métodos de polimerização. A porosidade foi similar à resina acrílica convencional.

Lai et al. (2004) avaliaram a influência dos níveis de energia de microondas na morfologia, dureza, porosidade, resistência flexural e solubilidade de resinas acrílicas com espessura de $10 \mathrm{~mm}$. As energias testadas foram: 80, 160, 240 e $560 \mathrm{w}$. Os tempos utilizados foram: 15, 10, 7 e 2 minutos, respectivamente. Depois, as muflas foram viradas e polimerizadas por mais 2 minutos a $560 \mathrm{w}$. O microondas utilizado tinha potência total de 800 w. Um grupo de resinas acrílicas convencionais foi polimerizado em água a $70^{\circ} \mathrm{C}$ por nove horas. Os espécimes foram avaliados em microscópio eletrônico. Pouca diferença foi encontrada na dureza e solubilidade entre as resinas de microondas e convencionais. A morfologia mais favorável quanto à fase borrachóide, a menor porosidade e a maior resistência flexural foram encontradas nas resinas convencionais. Quanto maior a energia empregada no forno de microondas, mais porosas ficaram as resinas. Apesar disso, os autores concluíram que a energia de microondas foi capaz de polimerizar resinas acrílicas eficientemente em um tempo menor.

Devlin e Kaushik (2005), determinaram se o tratamento de resinas acrílicas com água quente estava associado com uma redução na dureza superficial e branqueamento da superfície. Amostras da resina acrílica Hy-Pro Lucitone (Dentsply) foram imersas no peróxido alcalino Efferdent (Pfizer Consumer Health Care). Dez amostras foram imersas em água aquecida $\left(40^{\circ} \mathrm{C}\right)$ com um tablete de peróxido alcalino (Efferdent-grupo controle) e dez amostras foram imersas em água fervente $\left(100^{\circ} \mathrm{C}\right)$ com peróxido alcalino (grupo experimental). Foram realizados 30 ciclos de 24 horas. $\mathrm{O}$ efeito causado pela água quente foi o severo branqueamento de todas as amostras, enquanto que aquelas tratadas com água aquecida não foram afetadas. As amostras tratadas em água quente também absorveram mais água. O tratamento com peróxido alcalino e água resultou em uma significante redução na dureza das amostras, o que não ocorreu com as amostras em água aquecida. Os autores concluíram que a solução quente de peróxido alcalino causou uma supersaturação da superfície acrílica que resultou no branqueamento, e este branqueamento não foi reversível quando as amostras foram secas.

Sato et al. (2005) avaliaram a resistência à flexão e alteração de cor de resinas acrílicas termopolimerizáveis (Lucitone 550 - Dentsply; QC-20 - Dentsply; Triplex - Ivoclar) após 
imersão em soluções higienizadoras de próteses totais (Bony Plus Express - Bonyf AG; Corega Tabs - Block Drug Company; Efferdent Plus - Pfizer Inc.) por 15 minutos e 8 horas, simulando 30 dias de uso. O teste de resistência à flexão foi realizado em máquina de ensaios universais. Alterações de cor foram avaliadas por meio de fotografias obtidas dos corpos-deprova. À inspeção visual, não foi detectada qualquer alteração de cor. Concluiu-se que os higienizadores, quando usados de acordo com as instruções dos fabricantes, não afetam a resistência à flexão nem causam alterações de cor nas resinas acrílicas.

Azevedo et al. (2006) avaliaram a dureza e rugosidade de resinas acrílicas reembasadoras desinfetadas por diferentes períodos de tempos e condições. Os desinfetantes usados foram clorexidina a $4 \%$ e hipoclorito de sódio a 1\%. Foram produzidos corpos-deprova de 12 × 12 × $8 \mathrm{~mm}$ de dois materiais (Kooliner e Duraliner II) e um modelo de material usado para bases de dentaduras (Lucitone 550). A dureza e rugosidade foram determinadas após 1 hora da obtenção dos corpos-de-prova; após 48 horas de exposição em água a $37^{\circ} \mathrm{C}$; após 2 ciclos de desinfecção (1 minuto em clorexidina a 4\% + 10 minutos em um dos 2 desinfetante); após 7 dias de imersão nas soluções desinfetantes e após de 7 dias de imersão somente em água. Não foi encontrada nenhuma diferença significante depois da imersão nos 2 desinfetantes no tempo de 7 dias entre os materiais Kooliner e Lucitone 550. Houve significante diferença na dureza dos corpos-de-prova do material Duraliner II quando imersos nas soluções por 7 dias. Houve também uma pequena diferença na dureza dos corpos-deprova confeccionados pelos materiais Kooliner e Duraliner II quando submetidos a desinfecção em água por 7 dias. Quanto a rugosidade, não houve nenhuma diferença significante em nenhum dos corpos-de-prova submetidos à imersão nas soluções desinfetantes e em água por 7 dias.

Lima et al. (2006) avaliaram o efeito de higienizadores de prótese na rugosidade superficial de resinas acrílicas e no acúmulo de biofilme. Foram selecionados treze voluntários, os quais utilizaram dispositivos palatinos confeccionados com resina acrílica com rugosidade conhecida. As amostras foram submetidas uma vez por dia a um destes tratamentos: controle negativo, solução enzimática comercial (Ortoform) ou hipoclorito de sódio a $0,5 \%$. As amostras foram imersas oito vezes por dia em sucrose a $20 \%$ para aumentar a formação de biofilme. No quinto dia, o biofilme formado nos espécimes foi estimado pela quantidade de proteína removida da resina acrílica e a rugosidade de superfície das amostras foi novamente mensurada. Os resultados mostraram que a rugosidade da resina aumentou após o tratamento, mas a diferença entre os higienizadores foi insignificante. A menor quantidade de biofilme foi encontrada para o tratamento com hipoclorito de sódio a $0,5 \%$, 
mas o agente de higienização enzimático foi semelhante ao controle negativo. Os dados sugerem que a rugosidade da resina acrílica não foi alterada pelos higienizadores, mas a habilidade de reduzir o acúmulo de biofilme dependeu do produto utilizado.

Machado et al. (2007) fizeram um estudo com objetivo de comparar a resistência de flexão transversal em três materiais usados para base de dentaduras. Confeccionaram-se 30 corpos-de-prova ( 50 x 25 x 2,5 mm), 10 para cada um dos três materiais: Lucitone 199, Triad VLC e Eclipse. Estes foram quebrados na Máquina de Ensaio Universal. Comparando-se os resultados dos 3 materiais, obteve-se que houve uma diferença significante entre as resinas Eclipse, Lucitone 199 e Triad VLC. Os resultados do ensaio da resina Eclipse mostraram valores maiores para resistência, seguido pela resina Lucitone 199 e Triad VLC. Baseada nas propriedades e características da resistência de flexão, a resina Eclipse provou ser uma boa alternativa de resina convencional para base de dentaduras.

Peracini (2008) realizou um estudo para avaliar a alteração de cor de resinas acrílicas termopolimerizáveis (convencional e de microonadas) após imersões em soluções químicas higienizadoras de próteses totais em diferentes períodos de tempo. Foram confeccionados 200 espécimes (15x4mm), 100 de cada marca comercial Lucitone 550 e Onda Cryl, os quais foram imersos em diferentes soluções água destilada por 3 minutos; Bony Plus por 3 minutos; água destilada por 5 minutos; Corega Tabs por 5 minutos; água destilada por 20 minutos; Hipoclorito de sódio a $0,5 \%$ por 20 minutos; hipoclorito de sódio a $1 \%$ por 8 horas. A alteração de cor foi mensurada com espectrocolorímetro (Color Guide 45/0 BYK- Gardner) antes e após simulação de 180 dias de imersão. Os resultados mostraram que a resina acrílica Lucitone apresentou-se mais estável que a Onda Cryl. Para ambas as resinas, as pastilhas e os hipocloritos por 20 minutos $(0,5 \%$ e $1 \%)$ não provocaram alterações maiores que seus respectivos controles. A solução de hipoclorito a $1 \%$ causou maior alteração de cor que seus respectivos controles. Conclui-se que soluções efervescentes quando utilizadas de acordo com as instruções dos fabricantes e o hipoclorito de sódio a $0,5 \%$ e 1\% por 20 minutos diminuíram os valores de alteração de cor nas resinas acrílicas por um período de uso simulado de 180 dias.

\subsection{Dentes artificiais}

No ano de 1934 foi criada a resina acrílica (polimetil metacrilato PMMA), constituída na sua forma original pela união retilínea, em cadeia, de várias unidades de moléculas de metacrilato de metila, ligadas intramolecularmente por uniões covalentes (CRAIG; O'BRIEN; 
POWERS, 1988; FERRACANE, 2001; O'BRIEN, 1997.). Este material foi aclamado mais tarde como ideal para a confecção de dentes artificiais para próteses totais, superando a cerâmica até então mais comumente utilizada.

Os dentes de resina acrílica apresentam algumas características marcantes como união química com a resina acrílica da base da prótese, eliminando a necessidade de retenções mecânicas (BEALL, 1943; CRAIG; O’BRIEN e POWERS, 1988; HIRANO et al., 1998; KAWANO et al., 2002). Dentre outras características vantajosas foram citadas, alta resistência à rachaduras e ao ataque de solventes orgânicos, sensação mais natural ao contato dentário (BEALL, 1943), aparência mais natural (BEALL, 1943; WINKLER; MONASKY; KWOK, 1992), menor transmissão de carga ao rebordo residual (OGLE; DAVIS, 1998; WHITMAN et al., 1987), menor friabilidade (BEALL, 1943; WINKLER; MONASKY; KWOK, 1992), redução do ruído à oclusão (WINKLER; MONASKY; KWOK, 1992), facilidade na caracterização, maiores resistência ao impacto e flexural (WINKLER; MONASKY; KWOK, 1992), facilidade na realização do ajuste oclusal, recontorno e repolimento (CRAIG; O'BRIEN; POWERS, 1988), facilidade na obtenção da montagem (VON FRAUNHOFER; RAZAVI; KHAN, 1988). Por outro lado, os dentes de acrílico apresentam como desvantagens a baixa resistência ao desgaste (BEALL, 1943; CRAIG; O'BRIEN; POWERS, 1988; HARRISON e HUGGETT, 1965; HARRISON, 1973; HIRANO et al., 1998; KAWANO et al., 2002; WINKLER; MONASKY; KWOK, 1992) não apresentam estabilidade de cor (SATOH et al., 1993; WHITMAN et al., 1987), sofream ação de corantes orgânicos, água, luz solar, agentes químicos e absorvem odores facilmente. (WHITMAN et al., 1987).

O aperfeiçoamento da tecnologia de industrialização de dentes plásticos ocorreu com a introdução de máquinas de injeção para forçar o polímero fundido no interior dos moldes.

O principal avanço na produção dos dentes artificiais ocorreu na década de 50, com o advento dos agentes de ligação cruzada da resina acrílica (cross linking). Agentes cross linking são utilizados para aumentar a dureza e a resitência ao desgaste (OGLE, DAVID e ORTMAN, 1985). Entretanto, estudos relatam que dentes artificiais de resina acrílica com cross linking, quando comparados com os convencionais, têm menor adesão à resina da base das próteses. (LOYAGA- RENDON et al., 2007).

Recentemente foram introduzidos no mercado dentes de resina com melhores propriedades mecânicas no anseio de aumentar a longevidade das próteses, como dentes de resina IPN (Interpenetrated Polymer Network), dentes com dupla ligação cruzada de polímeros (DCL) e dentes de resina acrílica convencional com a adição de agentes 
inorgânicos em sua composição (HAGENBUCH, 1997). A resina composta microparticulada também é um material utilizado para a composição de dentes artificiais. A presença de partículas de carga inorgânica na estrutura polimérica dos dentes compósitos conduziu ao aumento da dureza superficial, e em contrapartida, reduziu a resistência ao impacto dos mesmos (SUZUKI; TAMURA, 2004).

Apesar da evolução das propriedades físicas do poli metilmetacrilato, o desgaste deste material ainda ocorre com o uso na boca. A propriedade de microdureza superficial e resistência à abrasão dos dentes artificiais de resina acrílica já foi confirmada anteriormente (SATOH et al., 1990), porém não se sabe se estas propriedades também se relacionam com a estabilidade de cor dos mesmos. Segundo estudos de Mandikos et al. (2001) e Zeng et al. (2005), resistência à abrasão e dureza estão relacionadas e são as propriedades mecânicas mais estudadas dos dentes artificiais.

Whitman et al. (1987) compararam a resistência ao desgaste e microdureza superficial de dentes de resina acrílica (Trubyte/Bioform, Denstply), resina acrílica IPN (Trubyte/Bioform IPN, Denstply) e resina composta microparticulada (Ivosit, Ivoclar). Para isso foi desenvolvido um aparelho de desgaste, baseado no sistema "pino-disco". Os fabricantes forneceram espécimes dos materiais em formato de disco de $18 \mathrm{~mm}$ de diâmetro e 2,5mm de espessura. Os espécimes de cada fabricante foram divididos em dois grupos de acordo com o pré condicionamento por uma semana a $37^{\circ} \mathrm{C}$ em água destilada (controle) e etanol $75 \%$ (solvente químico recomendado para uso como simulador de ação de alimentos). Os resultados demonstararam que a resina acrílica IPN e Isosit mostraram-se igualmente resistentes ao desgaste em água e etanol, ao passo que os dentes de resina acrílica convencional foram mais susceptíveis ao desgaste. No teste de dureza, os materiais armazenados em água apresentaram valores de dureza iniciais e finais aproximandamente iguais, logo, não houve amolecimento do material. Inversamente, o índice de dureza dos materiais imersos em etanol aumentou, indicando o amolecimento do material. Não houve correlação direta entre desgaste e dureza dos materiais, pois embora não tenha ocorrido diferença significante nos índices de desgaste em água e etanol das amostras de IPN e Isosit, ocorreu amolecimento na presença do etanol.

A estabilidade de cor é crucial para o sucesso estético dos dentes artificiais. Espectrofotometria e colorimetria, aplicadas em estudos in vitro e in vivo tornaram possível o estudo de numerosos parâmetros relacionados com a estabilidade de cor dos compóstitos (FERRACANE; MOSER; GREENER, 1985; RUYTER; NILNER; MOLLER, 1987). No entanto, segundo Van Der Burgt et al. (1990) as desvantagens do uso de colorímetros para a 
mensuração de cor de dentes incluem que o instrumento é designado para a medição de superfícies planas e lisas, e os dentes não são planos nem lisos, podendo possuir anomalias na superfície; além disso, os colorímetros com aberturas pequenas são propensos a uma significativa perda de efeitos nas margens de forma que a determinação da cor estará sujeita a erros.

Satoh et al. (1993) investigaram a susceptibilidade de dentes de alta resistência à ação de corantes. Foram avaliados cinco tipos de dentes artificiais: dois dentes plásticos de alta resistência, dois dentes plásticos convencionais e um de porcelana. Os corantes líquidos empregados no estudo foram: vermelho ( $2 \%$ de solução aquosa número 102 de corante de alimentos vermelho), marron ( $2 \%$ de solução aquosa de café) e amarelo ( $2 \%$ de solução aquosa de turmérico). Cada tipo de dente artificial foi dividido em três grupos de dez incisivos centrais superiores esquerdos imersos por 4 semanas nos diferentes corantes. Metade dos espécimes de cada grupo foi limpa diariamente através de vibração ultrassônica por 30 segundos. Os grupos individuais foram sub-divididos em dois subgrupos de cinco espécimes cada: com limpeza e sem limpeza. Os corantes foram usados por 24 horas e repreparados diariamente. A cor dos dentes foi mensurada antes (valor controle), 1 e 4 semanas após a imersão. O sítio de análise da cor foi o ponto de intersecção entre a mediana das linhas vertical e horizontal das faces vestibulares dos dentes. A análise da cor foi realizada com um sistema de análise de imagem e uma câmera colorida. Os sistema de cor empregado foi CIE $\mathrm{L}^{*}, \mathrm{a}^{*}, \mathrm{~b}^{*}$.

O valor de cada diferença de cor foi multiplicado por 0,92, obtendo o valor Nacional de Padronizações que determina a alteração de cor avaliada pelo olho humano. Os resultados demonstraram que os dentes de alta resistência foram menos susceptíveis à pigmentação que os dentes de resina convencional. Porém sofreram maior manchamento que os dentes de porcelana. Para todos os tipos de dentes, a limpeza diária em ultra-som reduziu a pigmentação em comparação com o grupo controle que não recebeu limpeza ultrassônica e o período de quatro semanas promoveu maior pigmentação dos dentes artificiais quando comparados ao período de uma semana.

Mutlu-Sagensen et al. (2001) afirmam haver três tipos de descoloração geralmente descritas: 1) descolorações externas, devido ao acúmulo de placas e manchas; 2) alterações na superfície e sub-superfície, implicando em degradação superficial e suave penetração e reação de agentes corantes com a camada superficial; 3) descolorações intrínsecas, devido a reações físico-químicas. Desta forma, em seu estudo, compararam a estabilidade de cor de dentes de porcelana comercialmente disponíveis, acrílico reforçado e acrílico convencional. Os 
espécimes foram divididos em três grupos e submetidos à imersão nas soluções de café filtrado, chá, Coca-Cola e água destilada. As medições de cor foram realizadas inicialmente e após 1 dia, 1 semana, 2 semanas e 4 semanas de imersão. Concluiu-se que a solução de café filtrado foi a mais cromogênica, que a porcelana apresentou-se mais estável à alteração de cor e que todas as soluções promoveram um leve manchamento nos dentes artificiais testados.

Nogueira (2002) analisaram a dureza dos dentes artificiais de resina acrílica (Dentron) submetidos a diferentes agentes de limpeza em função do tempo. Os molares artificiais foram incluídos em anéis de PVC com resina acrílica termo-ativada (Lucitone). Após a polimerização e demuflagem foram submetidos ao desgaste e polimento, produzindo uma superfície plana. A dureza Vickers foi medida antes e após seis meses de armazenamento das amostras em quatro tipos de soluções: água (controle), clorexidina, hipoclorito de sódio 1\% e solução caseira de hipoclorito de sódio diluído. Os resultados apresentaram uma redução significativa na dureza dos dentes artificiais imediatamente $(32,93)$ e seis meses após o condicionamento $(20,02)$. Os uso de agentes de limpeza promoveu um efeito sobre os dentes artificiais de resina acrílica similar à imersão em água.

Pavarina et al. (2003a) estudaram a influência do uso de três soluções desinfetantes na dureza Vickers de dois dentes artificiais de resina acrílica. Foram utilizados 32 dentes artificiais do mesmo modelo para cada marca. Após preparo das amostras, foram realizadas 12 leituras de dureza em um microdurômetro sob $100 \mathrm{~g}$ de carga por 30 segundos. Em seguida, os corpos-de-prova foram imersos em água destilada a $27^{\circ} \mathrm{C}$ por 48 horas e a dureza novamente registrada. Os espécimes foram então divididos em 4 grupos $(n=8)$. Nos grupos I, II e III, os espécimes foram imersos por 10 minutos nas seguintes soluções desinfetantes, respectivamente: gluconato de clorexidina a $4 \%$, hipoclorito de sódio a $1 \%$ e perborato de sódio 3,78\% e em seguida enxaguados por 3 minutos em água corrente. Os espécimes foram desinfetados duas vezes simulando a condição laboratorial quando as dentaduras são recebidas do paciente e antes de retornarem a ele. Os espécimes do grupo IV (controle) foram imersos em água pelo mesmo período total de 20 minutos. As medições da dureza foram realizadas após a desinfecção dos espécimes e também após o armazenamento final dos espécimes em água a $37^{\circ} \mathrm{C}$ por $15,30,60,90$ e 120 dias. Os resultados mostraram não haver diferença estatisticamente significante entre os materiais e as soluções testadas $(p<0,05)$. Contudo, houve um decréscimo contínuo na dureza relacionado com o tempo de armazenamento dos espécimes em água $(\mathrm{p}<0,05)$.

Devido à escassez de trabalhos envolvendo a ação de agentes higienizadores e desinfectantes nos dentes artificiais de próteses totais, Campanha et al. (2005) realizaram um 
estudo para avaliar o efeito da esterilização por microondas e da imersão em água na dureza Vickers de dentes de resina acrílica. Foram utilizados 32 molares de resina acrílica, os quais foram incluídos em tubos de PVC $(20$ x 20mm). Os dentes tiveram as suas faces oclusais planificadas com o uso de lixas d'água. Foram utilizadas 6 marcas de dentes (Dentron, Vipi Dent Plus, Postaris, Biolux, Trilux e Artiplus). Os corpos-de-prova foram divididos em 4 grupos $(\mathrm{n}=8)$. A dureza foi medida após polimento (grupo controle), após o polimeto seguidos de dois ciclos de esterilização por microondas a $650 \mathrm{~W}$ por 6 minutos e após polimento seguidos por 90 dias de imersão em água, e após polimento e seguidos de 90 dias de imersão em água e 2 ciclos de esterilização em microondas. Os resultados mostraram que a esterilização por microondas promoveu uma diminuição na dureza dos dentes. Para todas as marcas, não houve diferença significativa entre os grupos, exceto para o grupo da imersão por 90 dias e desinfecção por 2 ciclos, o qual apresentou diminuição nos valores de dureza. Os autores concluíram que a esterilização de dentes de resina acrílica em microondas à $650 \mathrm{~W}$ por 6 minutos pode ser usada sem efeitos prejudiciais na dureza de dentes imersos em ambiente úmido por 90 dias.

Rodrigues et al. (2005) avaliou a dureza superficial Knoop de três marcas comerciais de dentes artificiais de resina acrílica convencional (Trubyte Biotone, Vipi Dent Plus e Ivostar) e quatro marcas de resina acrílica melhorada (Biotone IPN, Trilux, Biolux e Vivodent). Os 10 corpos-de-prova foram seccionados, planificados e mensurados em três níveis de profundidade antes e após a realização do ataque ácido. Para avaliação da associação entre dureza e o índice de desgaste foram selecionadas três marcas comerciais com diferentes características: Biotone (resina acrílica convencional), Trilux (resina IPN) e Vivodent (resina com dupla ligação cruzada). A máquina de desgaste gerou a atrição dos espécimes contra porcelana glazeada e jateada durante 100.000 ciclos à velocidade de 4,5 ciclos por minuto sob lubrificação à água. Não houve diferença estatisticamente significante no desgaste entre as marcas testadas de resina acrílica melhorada $(p<0,05)$. Não houve associação entre a dureza superficial e a resistência ao desgaste das marcas avalidas no substrato jateado.

Loyaga-Rendon et al. (2007) avaliaram características de composição e dureza de novas marcas de dentes artificiais; duas marcas de resina acrílica convencional, três marcas de resina acrílica cross linking e sete marcas de resina composta. Uma relação significante entre dureza e conteúdo inorgânico foi observada. O tamanho da carga influencia nas propriedades da resina, tamanhos maiores de carga proporcionam maior dureza e alto módulo flexural, porém tamanhos menores de carga proporcionam superfície mais lisa. 
Mello (2007) avaliou a resistância à abrasão, microdureza superficial e estabilidade de cor de dentes artificiais de resina acrílica. Foram utilizados sete grupos de dentes artificiais das marcas Biolux, Trilux, Blue Dent, Biocler, Orthosit-Vivoldent, Postaris-Antaris, Gnathostar-Ivostar, compostos de 12 pré molares superiores de cada fabricante, sendo 6 contra antagonistas metálicos $(\mathrm{NiCr})$ e 6 contra antagonistas de resina indireta Solidex, os quais foram submetidos ao ensaio de abrasão. Como resultados concluiu que a os dentes da marca Postaris apresentou os menores valores de desgaste contra ambos os antagonistas. Para análise da microdureza superficial Vickers, foram utilizados seis incisivos laterais superiores de cada marca e três leituras (terço cervial, médio e incisal) foram realizadas. Os resultados mostraram que o grupo Biolux seguido do Antaris, Ivostar e Biocler apresentaram maiores valores de dureza diferenciando-se do Vivodent e Blue Dent, menos duros. Para o ensaio de estabilidade de cor, foram utilizados 6 incisivos centrais superiores direitos de cada marca comercial, submetidos ao processo de envelhecimento artificial acelerado. Cada dente teve sua cor medida antes e após o envelhecimento artificial em um espectrocolorímetro portátil. Houve diferenças estatisticamente significantes entre os grupos e a marca Blue Dent, sendo que os valores de alteração de cor foram clinicamente inaceitáveis. O grupo Antaris/Postaris teve a maior variação de cor e o grupo Biolux a menor variação de cor. Concluiu-se que o antagonista utilizado (metal ou resina) deve influenciar na escolha do dente artificial e que os dentes artificiais testados têm comportamentos diferentes quanto à resistência à abrasão, microdureza superficial e estabilidade de cor.

Kokskal e Dikbas (2008) avaliaram a estabilidade de cor de duas marcas de dentes de porcelana e três de resina acrílica. Os espécimes foram imersos em bebidas e em água destilada como controle. As medições de cor foram feitas por meio de espectrofotômetro antes e após a imersão por 1 dia, 1 semana, 2 semanas e 4 semanas de imersão. O autor concluiu que a estabilidade de cor foi significantemente afetada pelo período de imersão, que a solução de café instantâneo foi o agente mais cromogênico e que a porcelana foi mais resistente à alteração de cor que o acrílico.

\subsection{Reembasadores resilientes}

O uso clínico dos materiais reembasadores foi reportado pela primeira vez em 1943 por Tylman e em 1945 por Popper. Desde então o seu uso tem se tornado cada vez mais popular por promover maior conforto aos usuários de dentaduras devido à sua capacidade de absorção de forças (GOLL; SMITH; PLEIN, 1983; NIKAWA et al. 1994) distribuição da 
carga funcional sobre o rebordo (AYDIN et al., 1999; SINOBAD et al., 1992) e de adaptação à superfície protética e retenção da prótese (CRAIG; GIBBONS, 1961). Além disso, estes materiais têm sido utilizados nos tratamentos de rebordo atrofiado, bruxismo, xerostomia, e em próteses antagônicas à dentição natural (BOUCHER; HICKEY; ZARB, 1975). Entretanto, ainda nos dias atuais, questiona-se qual o tipo de reembasador mais adequado, que cumpra os propósitos de melhorar a qualidade de vida dos pacientes e qual sofre menos influência em suas propriedades físicas devido ao uso de higienizadores químicos existentes no mercado brasileiro.

Os reembasadores podem ser categorizados de acordo com suas estruturas químicas como acrílicos plastificados, resinas vinil, elastômeros de poliuretano e polifosfazina e elastômeros de silicone (ANUSAVISE, 1996). Esses materiais também podem ser classificados como provisórios ou definitivos e de acordo com sua polimerização em quimicamente e termicamente polimerizados (AYDIN et al., 1999; SINOBAD et al., 1992; WRIGHT et al., 1982). Os materiais acrílicos geralmente são constituídos de pó e líquido (STORER, 1962). Os materiais de uso prolongado incluem o copolímero de poli (metilmetacrilato) ou o copolímero de acrílico com plastificadores, que devem ser ésteres aromáticos ou ésteres e álcoois. Os materiais de tratamento utilizados no consultório (condicionadores de tecido) e removidos após três a sete dias consistem de pó de poli (vinil metacrilato) e de líquido contendo estéreis aromáticos e etanol (CRAIG; POWERS, 2004).

Para que um reembasador resiliente apresente sucesso clínico em longo prazo, Storer (1962) estipulou algumas propriedades desejáveis, tais como:

- não ser irritante e ser atóxico para a mucosa bucal, além de ser inodoro e insípido;

- ter estabilidade dimensional durante o processamento e o uso;

- apresentar mínima absorção de fluidos;

- apresentar alta resistência à abrasão;

- apresentar resiliência permanente;

- ter alta resistência de união ao material acrílico da base de próteses;

- apresentar processamento simples e ser de fácil reparo.

Os reembasadores resilientes ainda não preenchem estes requisitos e dessa forma, não solucionam todos os problemas causados pelas próteses totais.

Lamie e Storer (1958) avaliaram a dureza, resistência à abrasão, sorção de água e adesão à base de resina acrílica de diferentes tipos de materiais macios utilizados em próteses totais como as borrachas naturais, cloreto de polivinil (Provinil-p Ultra e Vernasoft), polivinil acetato (Jospi), copolímero de metil-metacrilato (Plastupalat) e borrachas de silicone. O teste 
de dureza foi baseado na quantidade de penetração de uma barra rígida, sobre uma amostra do material resiliente com espessura de 0,8 a $1,0 \mathrm{~cm}$ e diâmetro de $5,12 \mathrm{~cm}$. Os testes foram realizados antes da imersão em água e após intervalos regulares. O cloreto de polivinil foi considerado pelos autores como o material de escolha por possuir boa estabilidade dimensional durante o processamento, boa adesão à base de resina e baixa sorção de água. Já o polivinil acetato foi contra-indicado por perder seu componente plastificante, tornando-se rígido após alguns meses de uso. Os autores concluíram ainda, que os produtos à base de silicone são mais indicados para utilização clínica pela facilidade da técnica e pela baixa sorção de água.

Craig e Gibbons (1961) analisaram a dureza, alteração de peso, resistência de união, resistência ao rasgamento e estabilidade de cor em reembasadores resilientes. Para o estudo de dureza foi utilizado o Durômetro Shore A, 24 horas após o seu processamento e diariamente durante 20 semanas em amostras armazenadas em água destilada. Os valores obtidos sofreram grande variação entre as marcas comerciais testadas. Alguns materiais chegaram a ter seu valor próximo ao de uma base rígida de resina acrílica. A alteração de peso foi realizada a cada 48 horas utilizando uma balança analítica. Com exceção do Flexene, todos os materiais apresentaram aumento no peso, o qual variou de $0,6 \%$ a $4,3 \%$, após quatro semanas de imersão em água destilada. A resistência de união e ao rasgamento foram determinados em máquinas de ensaios mecânicos Instron, com velocidade de $25 \mathrm{~cm} / \mathrm{min}$. Os valores foram determinados após 48 horas para que se completasse o tempo de polimerização de cada material. Quanto à resistência de união, todos os materiais apresentaram diminuição dos valores com o passar dos dias. Já a resistência ao rasgamento teve seus valores aumentados após a estocagem. A estabilidade de cor foi avaliada após: a) exposição do material a uma lâmpada de luz ultravioleta por 24 horas; b) teste de estocagem das amostras em água destilada a $26^{\circ} \mathrm{C}$ por vinte semanas. Em alguns materiais, o teste mostrou ausência da alteração de cor, já em outros, as alterações variaram de moderadas a severas.

Bates e Smith (1965) realizaram testes laboratoriais e clínicos com diferentes materiais reembasadores. No teste laboratorial foram confeccionadas amostras com os materiais: Palasiv (Kulzer \& Co.), Neo-plastupalat (Farben fabriken Bayer A.G.), Coesoft (Coe Laboratories), Cora-line (Coralite Dental Products), Durabase (Reliance Dental Mfg. Co.), Flexene (Cosmos Dental Products), Soft Oryl (The William Getz Corp.), Molloplast B (Kostner \& Co.), Flexibase (Flexico Developments Ltd.), D.P.Silyne (Dental Perfection Co.), Verone R.S (Davis) e Corvic/DOP 70\% (Dental Mfg. Co.). Foram avaliadas as propriedades de absorção de água, absorção de óleo, estabilidade de cor, força adesiva, dureza, elasticidade 
e rigidez. Os efeitos de higienizadores na cor e na superfície foram analisados visualmente. Os higienizadores (ácido mineral diluído, peróxidos e hipocloritos) foram usados de acordo com as instruções dos fabricantes por 6 semanas. O tipo oxigenado causou bolhas na superfície dos materiais termopolimerizáveis e autopolimerizáveis quando usados a $60^{\circ} \mathrm{C}$. O higienizador hipoclorito causou branqueamento de todos os materiais, com exceção do Corvic/DOP 70\%. Os dados sugerem que nenhum dos higienizadores utilizados é adequado para os materiais resilientes testados. Clinicamente, dois dos materiais de forramento foram aplicados nas bases das próteses de 89 pacientes para avaliação do conforto, irritação da mucosa, gosto e os efeitos do uso. Ambos os materiais foram clinicamente satisfatórios.

Makila e Honka (1979) realizaram um estudo in vivo para avaliar algumas propriedades de um material reembasador resiliente de silicone termopolimerizável (Molloplast-B), dentre as quais alteração de cor e dureza. Foram pesquisados 37 pacientes, utilizando próteses totais superiores e inferiores, todos com fibromucosa saudável. As investigações foram realizadas em 4 etapas, de 2 a 8 semanas, e após 6, 12 e 30 meses de instalação da prótese total. Quanto à análise da cor, as próteses foram comparadas com uma amostra de base resiliente de $2 \mathrm{~mm}$ unida em resina e armazenada em água e foram observadas alterações em 33 próteses (86\%). Quanto ao endurecimento, em nenhuma prótese foi verificada esta alteração. Os autores observaram que a descoloração da base resiliente aconteceu principalmente devido ao uso de agentes de limpeza e que houve o crescimento fúngico maior em próteses submetidas à escovação mais rígida, devido à formação de nichos, mostrando que a maior desvantagem da base resiliente é a dificuldade de manutenção da limpeza sem danificar o material.

Davenport, Wilson e Spence (1986) avaliaram a compatibilidade dos limpadores de próteses com as bases resilientes e discutiram quais os melhores métodos de limpeza para esses materiais. Foram utilizados: Molloplast-B (base de borracha de silicone polimerizada pelo calor), Coe Super-Soft (resina acrílica polimerizada pelo calor) e Softic 49 (resina acrílica polimerizada por calor). Os produtos selecionados para limpeza foram: Toots Denture Cleanser (peróxido alcalino), Deepclean (ácido sulfâmico), Denclen (ácido mineral) e Dentural (hipoclorito alcalino). As amostras com $12 \mathrm{~mm}$ de diâmetro e $2 \mathrm{~mm}$ de espessura, consistiam em um disco de base resiliente $(2 \mathrm{~mm})$ sobre uma base de Perspex $(2 \mathrm{~mm})$. Três amostras de cada material foram imersas em soluções de cada produto de limpeza e seis amostras foram imersas em água a $37^{\circ} \mathrm{C}$ como grupo controle. As alterações visuais, a suavidade e a recuperação elástica das amostras testadas foram comparadas com o grupo controle. Após 5 semanas, a única alteração visual era o clareamento do Mollplast-B imerso 
em solução do Deepclean, sendo detectado já no sexto dia de imersão. Os autores verificaram apenas um leve aumento, mas nada significante, na suavidade após imersão nas soluções de limpeza. A recuperação elástica demonstrada pelo Molloplast-B após a imersão foi maior que a obtida pelos outros materiais.

Nikawa et al. (1994) estudaram os efeitos de higienizadores de próteses em materiais reembasadores macios. Seis materiais (Coe Comfort, Coe Soft, Fit Softer, GC Soft Liner, Hydrocast e Viscogel) foram imersos em doze higienizadores de próteses, de sete diferentes categorias (peróxidos alcalinos, peróxidos neutros com enzimas, enzimas, drogas brutas, ácidos, detergentes, higienizadores bucais). Os testes realizados para avaliar a deterioração dos materiais foram os de porosidade superficial e de distorção. Os autores encontraram que o grau de porosidade dos materiais reembasadores variou dependendo do tempo de imersão e da combinação material reembasador com o higienizador. Os autores citaram que os efeitos dos higienizadores à base de peróxidos, com poucas exceções, causou mudanças mais severas do que os outros tipos. Como conclusão, os clínicos devem escolher um material baseado não só nas suas propriedades microbiológicas, mas também no aspecto da compatibilidade do material higienizador com o material reembasador.

El-Hadary e Drummond (2000) estudaram a sorção de água, comparando os resultados entre um reembasador de silicone (Luci-soft) e um reembasador de resina acrílica plastificada (Permasoft). Foram utilizadas, duas técnicas de processamento, a laboratorial e a autopolimerizada para a confecção de 24 discos (45mm de diâmetro e $1 \mathrm{~mm}$ de espessura), os quais foram armazenados em água destilada a $37^{\circ} \mathrm{C}$ e testados após 1,4 e 6 semanas. Os discos usados na primeira semana foram testados novamente após 4 e 6 semanas de contínuo armazenamento. $\mathrm{O}$ ganho de peso foi calculado: Permasoft $(2,45 \% \pm 0,36 \%$ processados em laboratório e $1,76 \% \pm 0,08 \%$ autopolimerizado), Lucisoft $(0,41 \% \pm 0,17 \%)$ após 6 semanas de armazenamento. Os autores concluíram que Lucisoft possui maior sucesso clínico, pois apresentou os valores mais baixos para sorção de água.

Tan et al. (2000) comparam a cor, textura e dureza Shore A de um reembasador resiliente para próteses totais autopolimerizado com a superfície polida e sem polimento, após tratamento com soluções higienizadoras. Cinqüenta e oito espécimes de cada tipo (polido e não polido) foram expostos a 5 soluções de higiene contendo perborato, persulfato ou hipoclorito a $25^{\circ} \mathrm{C}$ ou $55^{\circ} \mathrm{C}$, continuamente por 4 meses e meio. As soluções eram renovadas 2 vezes por dia. Um grupo controle foi mantido em água. Antes e após os 4 meses e meio, a cor, a dureza e a textura superficial do reembasador foi avaliada por meio de um densitómetro de cor, um durômetro Shore A (Shore Instrument \& Mfg Co, Freeport, NY), e um 
rugosímetro de superfície, respectivamente. Diferença entre os grupos após o tratamento com o higienizador foi detectada por meio da análise de variância $(\mathrm{p}<0.05)$ e Teste de Tukey. A superfície rugosa dos espécimes após tratamento com o higienizador a $25^{\circ} \mathrm{C}$ ou $55^{\circ} \mathrm{C}$ exibiu alteração significante na cor com o higienizador contendo perborato quando comparado ao grupo controle e ao grupo do persulfato. Os espécimes com a superfície rugosa do grupo do perborato apresentaram dureza significativamente maior quando comparado com o grupo do hipoclorito a $25^{\circ} \mathrm{C}$. Não foram encontradas diferenças na textura da superfície após os tratamentos. Os autores concluíram que, após o tratamento do material resiliente com soluções contendo perborato, uma maior quantidade de componentes do material é perdida para a solução levando a uma maior alteração de cor dos espécimes sem polimento.

Polyzois e Frangou (2001) realizaram um estudo para avaliar a dureza de resina acrílica resiliente e de materiais para forramento em função do tempo, alteração dos procedimentos de polimerização e uso de seladores de superfície. Espécimes em forma de disco (40 mm de diâmetro e $10 \mathrm{~mm}$ de espessura) foram obtidos com a polimerização dos materiais em água aquecida, elevando-se a temperatura e em temperatura ambiente. Cinco amostras foram usadas para cada método de processamento. Metade das amostras foi tratada com um selador de superfície, enquanto a outra metade não recebeu qualquer tratamento de superfície. Depois de processadas, as amostras foram imersas em água a $37^{\circ} \mathrm{C}$ por 1 ano. A dureza dos espécimes foi avaliada mensalmente, com o auxílio de um Durômetro Shore A. Os corpos-de-prova apresentaram diferenças de dureza relacionadas ao material e ao tempo após o processamento. A resina para forramento termopolimerizada mostrou um aumento significativo da Dureza Shore A no decorrer do período experimental. O aumento da dureza foi observado em todos os materiais com o passar do tempo, mas este aumento foi mais pronunciado com o material de forramento. O tratamento de superfície manteve a maciez dos materiais somente quando as amostras foram polimerizadas em temperatura ambiente (simulando a temperatura da cavidade oral). O método de processamento e o tempo decorrido após o processamento causaram alteração na dureza superficial dos materiais testados.

Parr e Rueggeberg (2002) avaliaram a dureza de dois materiais reembasadores resilientes, um autopolimerizál (Tokuyama Soft Relining Paste) e o outro processado convencionalmente em laboratório (Luci-Soft), ambos após um ano de imersão em água. Os espécimes autopolimerizáveis foram confeccionados em forma de disco $(31 \mathrm{~mm}$ x $10 \mathrm{~mm}$ espessura) em moldes de anéis de alumínio de acordo com orientações do fabricante. Os espécimes termopolimerizáveis foram fabricados empregando um anel de tamanho similar com uma mufla para dentadura convencional, sendo após, processado em água em ebulição 
por três horas e meia. No total foram obtidos 96 espécimes, das quais um lote completo não foi imerso em água, enquanto que o outro foi testado imediatamente após a estocagem em água destilada a $37^{\circ} \mathrm{C}$ por um período de um dia, uma semana, um mês e um ano. Para o teste de dureza abaixou-se uma haste vertical sob uma força de $1 \mathrm{~kg}$, a qual foi lentamente comprimida contra o centro dos espécimes e a maior leitura foi anotada. Foram obtidas três leituras para cada espécime. Os valores de dureza foram significativamente maiores para o material processado em laboratório do que para o autopolimerizável, a cada intervalo de tempo, após a polimerização. Os valores de dureza dos espécimes autopolimerizáveis foram constantes após uma semana de armazenamento em água, enquanto tais valores aumentavam de acordo com o tempo de imersão em relação aos processados em laboratório.

Pinto et al. (2002) determinaram o efeito da termociclagem sobre a deformação permanente dos materiais reembasadores resilientes Eversoft composto por polimetilacrilato e Mucopren soft composto por poli (vinil) siloxano. Foram confeccionados 20 corpos-de-prova para cada material a partir da inclusão de matrizes cilíndricas em muflas convencionalmente. Metade das amostras, para cada material, foi armazenada por 24 horas em água destilada a $37^{\circ} \mathrm{C}$ na estufa e outra metade foi submetida a ciclos térmicos. Em seguida, as amostras foram submetidas a cargas compressivas e indicou-se a leitura da deformação e recuperação elástica. A importância do ensaio está na indicação da falta de recuperação elástica do Eversoft quando comparado com o Mucopren soft, pois o Mucopren soft não apresentou diferença significativa após tratamento térmico, já para o Eversoft a deformação permanente foi maior após o ciclo térmico.

Jin et al. (2003) avaliaram a rugosidade superficial e a alteração de cor de 6 reembasadores macios para próteses totais após a imersão em soluções de higiene (peróxido alcalino, peróxido neutro com enzima e enzimas). Os materiais foram imersos na solução de higiene por 8 horas a temperatura ambiente, e imersos em água destilada para completar 24 horas a $37^{\circ} \mathrm{C}$, por um período de 180 dias. A rugosidade superficial foi mensurada por meio de um rugosímetro de contato (Surfcorder SE3300). A estabilidade de cor foi mensurada por um instrumento fotométrico (Chroma Meter34, CR-321) e calculada por meio do sistema CIE LAB. O material a base de silicone autopolimerizável (Evatouch) exibiu severas alterações na rugosidade superficial após imersão em todas as soluções testadas e o material GC Denture Relining apresentou as menores alterações.

Yilmaz et al. (2005) estudaram a efetividade de quatro soluções desinfetantes (hipoclorito de sódio 5,25\%, hipoclorito de sódio a $2 \%$, deconex a $5 \%$ e solução de savlex a $5 \%$ ) em quatro materiais reembasadores macios (Tempo, Immediate, Flexacryl soft e Ufi Gel 
P) contaminados com Stafilococcus aureus, Streptococos sobrinus e Candida albicans. Corpos-de-prova $(n=5$, total $=240)$ dos quatro reembasadores resilientes foram contaminados com cada um dos microorganismos, e em seguida, foram imersos por cinco minutos em cada solução desinfetante. Os corpos-de-prova do grupo controle (um de cada material; $n=5$, total = 60) foram imersos em água destilada por cinco minutos. Os resultados mostraram uma redução significante no número de microorganismos em todos os grupos testados, mas com o hipoclorito de sódio a 5,25\% apresentando a maior redução de todas. Os autores concluíram que o hipoclorito de sódio a $5,25 \%$ foi o melhor desinfetante entre os testados e que o tempo de imersão dos outros higienizadores poderia ser maior para alcançar resultados mais significativos.

Kiat-Amnuay et al. (2005) estudaram a influência da estocagem em água na dureza de cinco reembasadores macios (Luci-Soft, Molloplast-B, Tokuyama soft relining, Novus e Permasoft). Como o Permasoft possui em seu kit um selante, este material foi testado de três maneiras: a- sem aplicação do selante, b- com aplicação inicial do selante, c- aplicação do selante todo mês. Os corpos-de-prova produzidos foram estocados em água a $37^{\circ} \mathrm{C}$, a qual era trocada a cada duas semanas. Os corpos-de-prova foram submetidos a um Durômetro Shore A-2 após 16,7 minutos; 27,8 horas; 11,6 dias; 34,7 dias; 115 dias e 347 dias de imersão. Após os primeiros testes, o material que apresentou a maior maciez foi o Permasoft seguido do Tokuyama soft relining. Como resultados finais, os autores encontraram que o Tokuyama soft relining foi o que menos sofreu alteração após os 347 dias de imersão, seguido por Luci-Soft, Novus, Permasoft com aplicação inicial do selante, Molloplast-B, Permasoft sem aplicação do selante e Permasoft com aplicação mensal do selante. Os autores concluíram que o material que melhor respondeu à imersão foi o Tokuyama soft relining e que o Permasoft foi o que sofreu mais alteração de dureza.

Pavan et al. (2007) avaliaram os efeitos da desinfecção com soluções químicas (glutaraldeído a $2 \%$, hipoclorito de sódio a 5\% e clorexidina 5\%) e energia de microondas na dureza de 4 materiais reembasadores de longa duração para dentaduras. Foram confeccionados 40 espécimes retangulares de cada material (Molloplast-B, Ufi Gel P, Eversoft e Mucopren soft) sendo que 10 amostras foram imersas nas diferentes soluções por 10 minutos ou colocadas em forno microondas por 3 minutos a $500 \mathrm{~W}$ de potência. Os valores de dureza foram obtidos por meio de um durômetro Shore A antes do primeiro ciclo de desinfecção (controle) e após 2 ciclos de desinfecção. Os dados foram submetidos à Análise de Variância e Teste de Tukey $(\mathrm{P}<0.01)$. Os maiores valores de dureza foram obtidos com o Molloplast-B, independente da técnica de desinfecção. O Mucopren soft demonstrou valores 
intermediários e o Ufi Gel P e o Eversoft os menores valores de dureza Shore A. Para o Molloplast-B, o número de ciclos de desinfecção não teve efeito sobre a dureza dos materiais estudados e técnicas. A utilização de dois ciclos de desinfecção não promoveu alteração da dureza Shore A dos materiais. A solução de glutaraldeído demostrou os maiores valores de dureza para o Molloplast-B, Mucopren soft, e Ufi Gel P. O Eversoft não apresentou diferença na dureza quando submetido aos diferentes métodos de desinfecção.

Saraç et al. (2007) investigaram a estabilidade de cor de reembasadores resilientes e a efetividade de higienizadores de dentaduras na remoção de corantes alimentares depositados em reembasadores à base de resina acrílica (Viscogel) e à base de silicone (Mollosil), em diferentes períodos de tempo. Para cada material, 30 espécimes $(15 \mathrm{~mm}$ de diâmetro e $3 \mathrm{~mm}$ de espessura) foram estocados em água destilada por 24 horas a $37^{\circ} \mathrm{C}$. A mensuração da cor inicial foi realizada por meio de um colorímetro para áreas pequenas. Os espécimes de cada material foram divididos em três grupos $(n=10)$ para imersão por 14 horas ( 2 horas/ 7 dias) em eritrosina a 3\%, tartrazina e amarelo crepúsculo, corantes alimentares, para então ser realizada a segunda mensuração da cor. Em seguida, os espécimes de cada grupo foram divididos em dois subgrupos $(\mathrm{n}=5)$ e foram imersos em higienizadores de dentaduras (Fittydent e Curadent Weekly) por 8 horas, e a terceira mensuração da cor foi realizada. Estes procedimentos foram realizadas até completar os 7 dias. Outras três mensurações de cor foram realizadas ao final da simulação de períodos de 1, 2 e 3 meses. Os valores da alteração de cor $(\Delta E)$ foram analisados por meio de análise de variância e Teste de Bonferroni. Houve diferença significante entre os materiais e os higienizadores. Não houve diferença significante entre os corantes alimentares. Os higienizadores de dentaduras mostraram diferenças significantes, sendo que o Fittydent promoveu menores valores de $\Delta \mathrm{E}$ que o Curadent. $\mathrm{O}$ material à base de silicone (Mollosil) mostrou ser mais resistente ao manchamento. Com relação aos higienizadores o Fittydent foi mais efetivo que o Curadent.

Malheiros-Segundo et al. (2007) avaliaram as propriedades físicas (sorção de água, solubilidade, dureza e alteração de cor) de materiais reembasadores para prótese (Kooliner GC América Inc.; Elite Soft - Kettenbach) após imersão em pastilha efervescente (Corega Tabs- Block Drug Company) por 5 minutos diários. A sorção e solubilidade foram avaliadas após 120 dias de imersão. A alteração de cor foi avaliada após 30 e 120 dias, com o auxílio de um espectrocolorímetro (BYK-Gardner). A dureza foi avaliada no início, após 30 e 60 dias de imersão. Em todos os testes foram confeccionados grupos controles (imersão em saliva artificial a $37^{\circ} \mathrm{C}$ ). Concluiu-se que o perborato de sódio não influenciou de forma significante 
nas propriedades avaliadas, sendo que o material Kooliner apresentou maior estabilidade. $\mathrm{O}$ tempo interferiu em todas as propriedades testadas.

Mutluay et al. (2008) realizaram um estudo com o objetivo de avaliar o desempenho clínico de quatro reembasadores macios indicados por até 12 meses de uso. Trinta e três pacientes edentados foram selecionados para o estudo e tiveram suas próteses aleatoriamente reembasadas com Molloplast B, GC Reline Soft, Silagum Confort, ou Mollosil Plus. O desempenho dos materiais foi avaliado por meio de nove critérios durante 3, 6 e 12 meses: a integridade física, detalhes superficiais, aderência, cor, odor, acúmulo de placa, resiliência, condições da mucosa e higiene. Uma escala de quatro pontos $(1=$ fraco, 2 = médio, 3 = bom, 4 = excelente) foi utilizada. Os autores encontraram como resultados que a porcentagem de pacientes analisados após 3, 6 e 12 meses foram 91\%, 91\% e 66\%. Aos 6 meses, 96\% dos escores apresentaram-se como bom ou excelente e as maiores variações foram observadas para a integridade física, detalhes de superfície, cor e a colonização fúngica. A colonização fúngica foi o problema mais comumente observado, e foi a única razão do fracasso dentro de 12 meses. Os autores concluíram que o desempenho clínico de todos os reembasadores foi ligeiramente prejudicado durante os 12 meses de observação.

A busca por um produto ideal para higiene de próteses totais ainda é meta de estudos na área odontológica. Para tanto, propôs-se a avaliação da solução à base de mamona ( Químico responsável: GILBERTO CHIÉRESE) produzida no Instituto de Química da Universidade de São Paulo, como um possível higienizador de próteses totais. Os prazos de validade deste produto foram obedecidos neste estudo. 
O objetivo deste trabalho foi:

Avaliar os efeitos de soluções à base de mamona (Ricinus communis) e de hipoclorito de sódio nas propriedades físicas e mecânicas de materiais para confecção de próteses totais em função de dois períodos de imersão.

- Resina acrílica polimerizável em banho de água (convencional) e em microondas;

- Dentes artificiais com três diferentes marcas;

- Reembasadores resilientes com duas diferentes marcas.

As variáveis analisadas foram durezas, rugosidade, resistência à flexão e alteração de cor. 
Os materiais empregados para a realização deste estudo estão descritos nas tabelas 1,2 e 3 .

Tabela 1 - Resinas acrílicas termopolimerizáveis empregadas.

\begin{tabular}{l|l|l|l}
\hline Nome comercial & & \multicolumn{1}{|c}{ Fabricante } & Lote \\
& Polimerização & \multicolumn{1}{|c}{} \\
\hline $\begin{array}{l}\text { Vipi (Rosa médio } \\
\text { com veias) }\end{array}$ & Convencional & $\begin{array}{l}\text { Dental Vipi Ltda. Ind. Com. Imp. } \\
\text { Exp. De Produtos Odont., Ind. } \\
\text { Brás., Pirassununga, SP, Brasil }\end{array}$ & $\begin{array}{l}\text { Pó: 4484 } \\
\text { Líquido:4384 }\end{array}$ \\
\hline $\begin{array}{l}\text { Onda Cryl (Rosa } \\
\text { com veias) }\end{array}$ & Microondas & $\begin{array}{l}\text { Artigos Odontológicos Clássico } \\
\text { Ltda, São Paulo, SP, Brasil }\end{array}$ & $\begin{array}{l}\text { Pó: 71505 } \\
\text { Líquido:061005 }\end{array}$ \\
\hline
\end{tabular}

Tabela 2 - Dentes artificiais de resina acrílica empregados.

\begin{tabular}{l|l|l|l}
\hline \multicolumn{1}{c|}{$\begin{array}{c}\text { Nome } \\
\text { comercial }\end{array}$} & Modelo & \multicolumn{1}{|c}{ Fabricante } & \multicolumn{1}{|c}{ Lote } \\
\hline Vipi & 28 & $\begin{array}{l}\text { Dental Vipi Ltda. Ind. Com. Imp. Exp. De } \\
\text { Cor: } 66\end{array}$ & $\begin{array}{l}\text { Produtos Odont., Ind. Brás., Pirassununga, SP, } \\
\text { Brasil }\end{array}$ \\
\hline Biolux & $\begin{array}{l}\text { V17 } \\
\text { Cor: } 66\end{array}$ & $\begin{array}{l}\text { Dental Vipi Ltda. Ind. Com. Imp. Exp. De } \\
\text { Produtos Odont., Ind. Brás., Pirassununga, SP, } \\
\text { Brasil }\end{array}$ & 6907 \\
\hline Trilux & $\begin{array}{l}\text { E5 } \\
\text { Cor: } 66\end{array}$ & $\begin{array}{l}\text { Ruthinium Group Badia Polesine, Rovigo } \\
\text { Itália }\end{array}$ & 6600 \\
\hline
\end{tabular}

Tabela 3 - Reembasadores resilientes empregados.

\begin{tabular}{c|c|c|c}
\hline Nome comercial & Tipo de resina & Fabricante & Lote \\
\hline Elite Soft & Polivinilsiloxano & Zhermack, Badia Polesine, Rovigo, Itália & 20893 \\
\hline Mucopren Soft & Polivinilsiloxano & Kettenbach Dental, Eschenburg, Alemanha & 50122 \\
\hline
\end{tabular}

\section{Preparo dos corpos-de-prova}

\subsection{Resina acrílica}

\subsubsection{Confecção dos corpos-de-prova para os testes de dureza e alteração de cor.}

Trinta discos de cada resina acrílica (termopolimerizadas de modo convencional - RAC e em microondas - RAM) foram obtidos a partir de uma matriz metálica com $14 \mathrm{~mm}$ de diâmetro e 4 mm de espessura (Seção de Oficinas de Precisão, USP, Ribeirão Preto, SP, Brasil) (Fig. 1). As 
matrizes metálicas foram incluídas em muflas metálicas convencionais (OGP Produtos Odontológicos Ltda., São Paulo, SP, Brasil) (Fig. 2) e para microondas (Vipi Indústria, Comércio, Exportação e Importação de Produtos Odontológicos Ltda., Pirassununga, SP, Brasil) (Fig. 3) com silicone de alta viscosidade (Zetalabor; Zhermack S.p.A, Badia Polesine, Rovigo, Italy) e gesso pedra tipo III (Gesso Rio, Orlando Antônio Bussioli ME, Rio Claro, SP, Brasil). Para que a superfície do gesso apresentasse lisura e ausência de bolhas, foi utilizado um vibrador odontológico (VH Softline, VHMidas Dental Products Ltda, Araraquara, SP, Brasil). Em cada mufla foram colocadas seis matrizes. Após a presa do gesso, as muflas foram separadas e as matrizes metálicas removidas dos moldes de silicone. As resinas para base de dentadura foram manipuladas de acordo com as instruções dos fabricantes (Quadro1). Na fase ideal de cada tipo de resina, este material foi acondicionado nos moldes por meio do uso de uma espátula número 24 (Duflex, SSWhite, Rio de Janeiro, Brasil) e com uma prensa de bancada (Prensa Hidráulica Protecni, Protecni Equip. Med., Araraquara, SP, Brasil) foi realizada a prensagem das resinas com carga inicial de $500 \mathrm{kgf}$ e final de $1.000 \mathrm{kgf}$, a qual foi mantida por 60 minutos. Posteriormente, foi realizada a polimerização de acordo com as recomendações do fabricante em um forno de microondas (Panasonic NN-S56B/56 28L, Manaus, AM, Brasil) para a resina de microondas e em uma polimerizadora eletrônica (Termocycler T100, Ribeirão Preto, SP, Brasil) para a resina convencional.

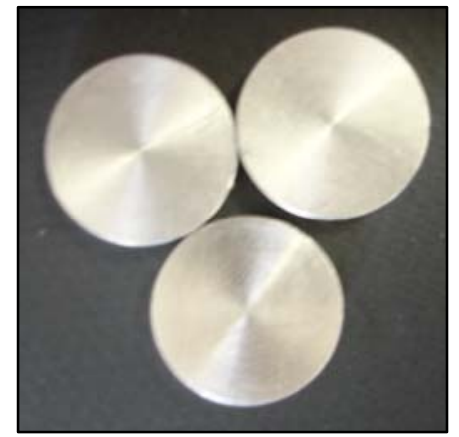

Figura 1 - Matrizes metálicas circulares

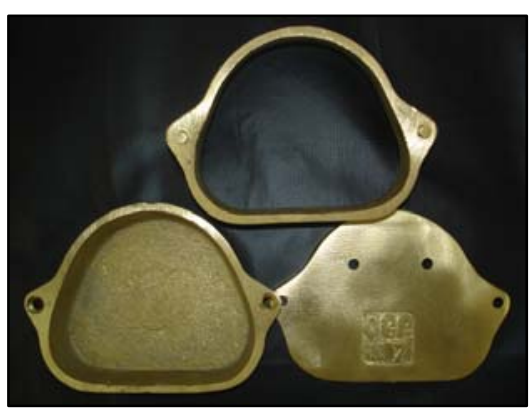

Figura 2 - Mufla para polimerização de modo convencional.

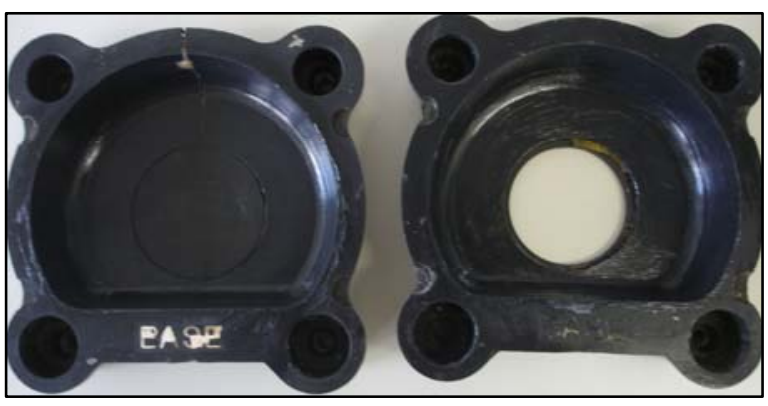

Figura 3 - Mufla para polimerização em microondas. 
Quadro 1 - Ciclos de polimerização das resinas acrílicas empregadas.

\begin{tabular}{|l|l|l|l|l|}
\hline $\begin{array}{c}\text { Nome } \\
\text { comercial }\end{array}$ & $\begin{array}{l}\text { Proporção } \\
\text { pó/líquido }\end{array}$ & Prensagem & $\begin{array}{l}\text { Descanso } \\
\text { da mufla }\end{array}$ & \multicolumn{1}{|c|}{ Polimerização } \\
\hline Vipi & $21 \mathrm{~g} / 10 \mathrm{ml}$ & $\begin{array}{l}\text { Fase } \\
\text { plástica }\end{array}$ & $\begin{array}{l}30 \\
\text { minutos }\end{array}$ & $\begin{array}{l}30 \text { minutos para o aquecimento até } 65^{\circ} \mathrm{C} ; \\
\text { manutenção a } 65^{\circ} \mathrm{C} / 1 \text { hora; 30 minutos } \\
\text { para elevar a temperatura de } 65^{\circ} \text { para } \\
100^{\circ} \mathrm{C} \text {; manutenção à } 100^{\circ} \mathrm{C} / 1 \text { hora }\end{array}$ \\
\hline $\begin{array}{l}\text { Onda } \\
\text { Cryl }\end{array}$ & $21 \mathrm{~g} / 7 \mathrm{ml}$ & $\begin{array}{l}\text { Fase } \\
\text { fibrosa }\end{array}$ & $\begin{array}{l}30 \\
\text { minutos } \\
\text { a 1 hora }\end{array}$ & $\begin{array}{l}\text { Forno de microondas com potência de } \\
800 \text { a 900 watts: 3 minutos a 40\%, } \\
\text { minutos a 0\% (mínima) e 3 minutos a } \\
90 \% .\end{array}$ \\
\hline
\end{tabular}

Após a polimerização, as muflas foram mantidas em temperatura ambiente por 12 horas para o seu resfriamento e demuflagem dos corpos-de-prova, os quais ficaram imersos em água destilada a $50^{\circ} \mathrm{C}$ por 24 horas em estufa (Odontobrás Ind. e Com. Equip. Med. Odont. Ltda., Ribeirão Preto, SP, Brasil) para eliminação do monômero residual.

Os excessos de resina dos corpos-de-prova foram removidos com fresas (Maxi-Cut; Malleifer SA, Ballaigues, Switzerland). As dimensões finais e o polimento foram obtidos em uma politriz horizontal (DPU-10, Panambra Industrial e Técnica AS, São Paulo, SP, Brasil) com lixas d'água (números 180, 220, 360 e 400 - Norton Saint Gobain Acessórios Ltda., Guarulhos, SP, Brasil) em todos os lados para eliminar qualquer irregularidade visível e, posteriormente em politriz de bancada (Nevoni, São Paulo, SP, Brasil) com rodas de algodão e branco de espanha (Branco Rio Orlando, Antônio Bussioli ME, Rio Claro, SP, Brasil). As dimensões dos corpos-de-prova foram confirmadas com um paquímetro manual (CD-6" CSXB - Mitutoyo Sul Americana Ltda., Suzano, SP, Brasil). Cada corpo-de-prova foi identificado, em sua lateral, com uma marcação realizada com broca (PM 701 - Labordental Ltda, São Paulo, SP, Brasil) para identificação (Fig. 4 e 5).

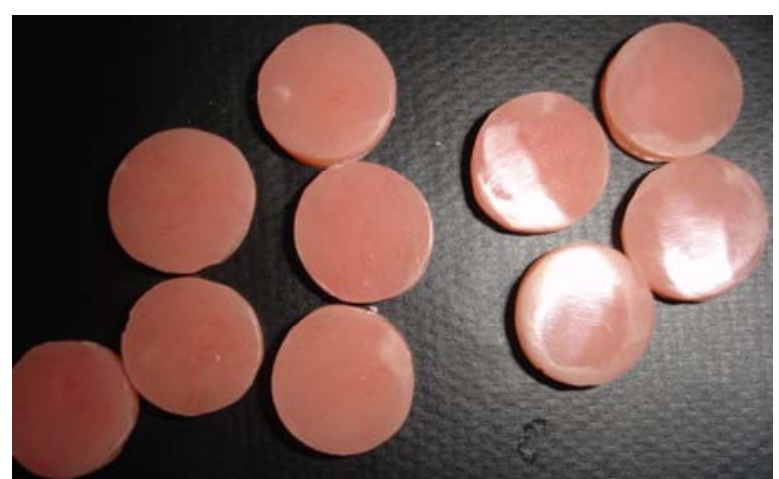

Figura 4 - Corpos-de-prova em resina acrílica convencional.

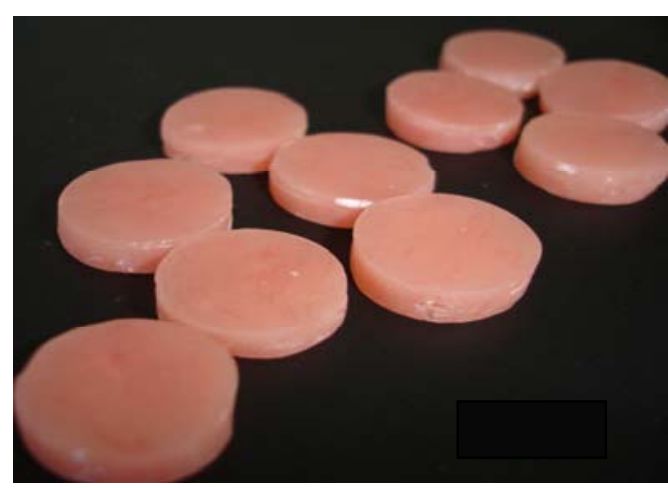

Figura 5 - Corpos-de-prova em resina acrílica de microondas. 


\subsubsection{Confecção dos corpos-de-prova para os testes de resistência à flexão} e rugosidade superficial.

Sessenta corpos-de-prova retangulares $(65,0 \times 10,0 \times 3,3 \mathrm{~mm})$ de cada tipo de resina acrílica foram obtidos com o uso de uma matriz de proporções um pouco maiores $(66,0$ x 12,0 x 5,0 mm) (Fig. 6) para a manutenção das medidas ideais requeridas para os testes após o procedimento de acabamento e polimento (Fig. 7). A mesma metodologia descrita acima para a obtenção dos corpos-de-prova foi utilizada.

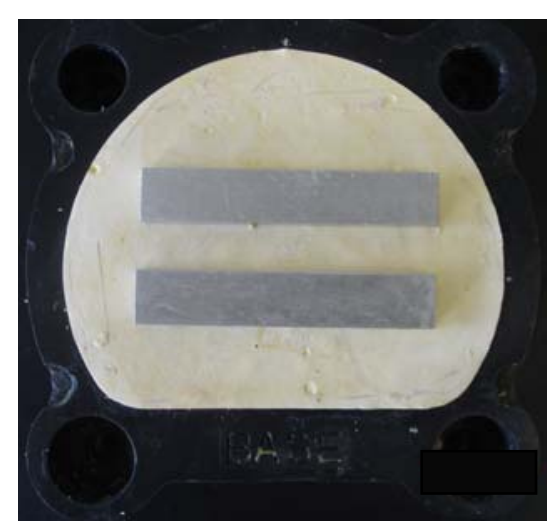

Figura 6 - Matrizes metálicas retangulares posicionadas na mufla para inclusão.

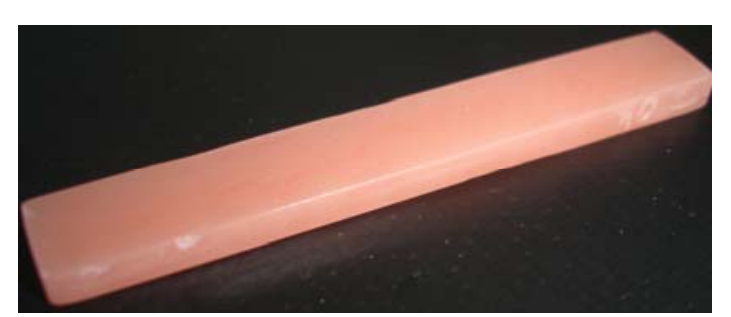

Figura 7 - Corpos-de-prova retangulares após o polimento. 


\subsection{Dentes artificiais}

\subsubsection{Confecções dos corpos-de-prova para os testes de dureza, alteração} de cor e rugosidade.

Para os dentes artificiais de resina acrílica foram selecionados os incisivos centrais superiores de maiores dimensões para cada marca comercial. Foram obtidos 90 corpos-deprova, provenientes de 90 incisivos centrais superiores (30 de cada marca comercial), por meio da planificação da superfície palatina dos incisivos centrais para permitir as medições da dureza e rugosidade (Figs. 8 e 9). O desgaste e polimento foram realizados em uma politriz horizontal (DPU 10, Panambra Industrial e Técnica AS, São Paulo, SP, Brasil) com lixas d'água (números 180, 220, 360 e 400, Norton Saint Gobain Acessórios Ltda., Guarulhos, SP, Brasil) até a obtenção de uma superfície plana, lisa e com uma espessura na região cervical, mediana e incisiva de, respectivamente, $4 \mathrm{~mm}, 3,3 \mathrm{~mm}$ e $2 \mathrm{~mm}$. As dimensões dos corpos-deprova foram confirmadas com um paquímetro manual (CD-6" CSX-B, Mitutoyo Sul Americana Ltda., Suzano, SP, Brasil). Cada corpo-de-prova recebeu em sua lateral uma marcação realizada com broca (PM 701 - Labordental Ltda, São Paulo, SP, Brasil) para identificação de seu número.

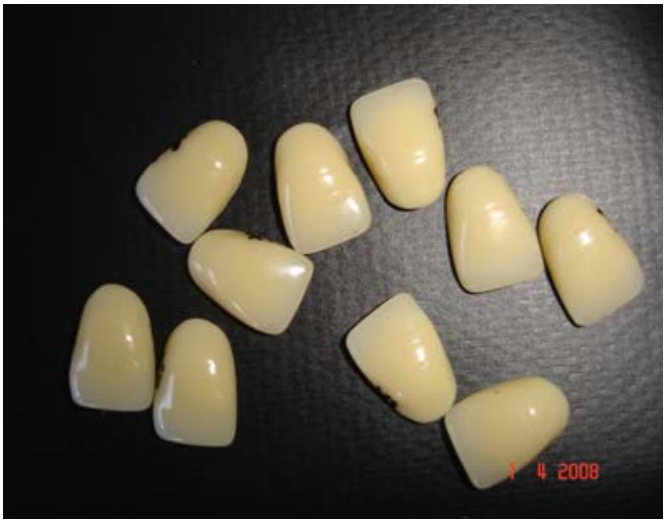

Figura 8 - Dentes artificais de resina acrílica.

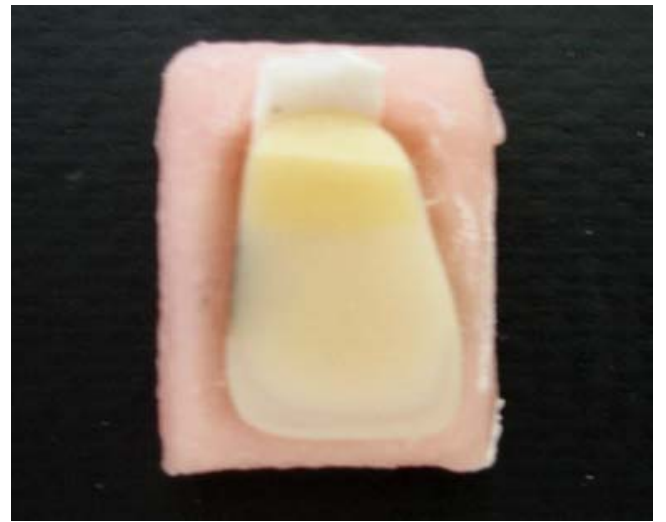

Figura 9 - Dente com a face palatina planificada. 


\subsection{Reembasadores resilientes}

\subsubsection{Confecção dos corpos-de-prova para os testes de dureza, alteração} de cor e rugosidade superficial.

Os 30 corpos-de-prova para cada material reembasador resiliente foram obtidos por meio da inclusão das matrizes metálicas em forma de disco (14 $\mathrm{mm}$ x 4mm) em muflas metálicas conforme descrito no item 1.1.1. Os reembasadores resilientes Elite Soft e Mucopren Soft foram inseridos em cada molde com uma seringa aplicadora que permite a correta mistura e dosagem do material. A mufla foi fechada e levada à prensa de bancada com carga inicial de $500 \mathrm{kgf}$ e final de $1000 \mathrm{kgf}$ onde permaneceu até a presa do material seguindo as recomendações do fabricante. Após a presa, foi realizada a demuflagem, remoção dos excessos dos corpos-de-prova com uma tesoura afiada de ponta reta (Duflex, SSWhite, Rio de Janeiro, Brasil) e lâmina bisturi número 15 (Feather, Joinville, SC, Brasil). Marcações, com um explorador duplo aquecido (Duflex, SSWhite, Rio de Janeiro, Brasil), foram realizadas na lateral dos espécimes para identificação e posterior realização dos ensaios (Fig. 10 e 11)

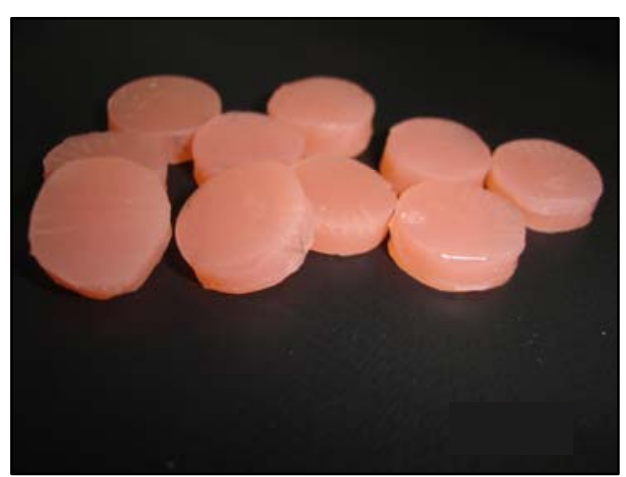

Figura 10 - Corpos-de-prova de Elite Soft.

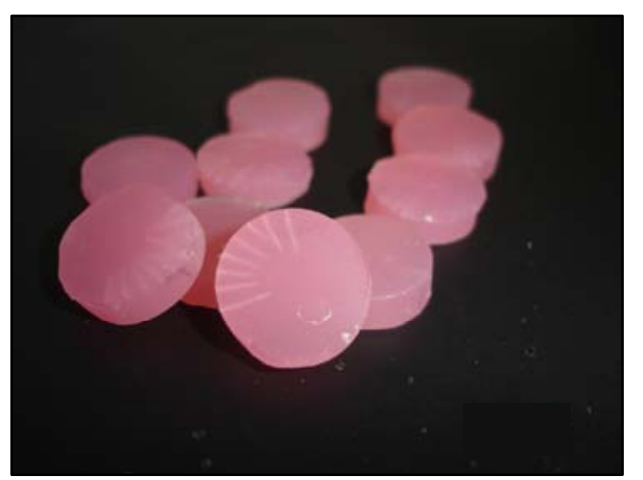

Figura 11 - Corpos-de-prova de Mucopren Soft. 


\section{Formação dos Grupos}

Dez corpos-de-prova de cada material foram distribuídos, aleatoriamente, em 3 grupos de soluções:

Grupo 1) Controle negativo: água destilada;

Grupo 2) Controle positivo: Hipoclorito de sódio a 1\% (Asfer Ind. Química Ltda., São Paulo, Brasil, lote 162729);

Grupo 3) Experimental: Solução experimental de mamona a 2\% (Instituto de Química, Universidade de São Paulo, São Carlos, São Paulo, Brasil).

Para a imersão, $200 \mathrm{ml}$ de cada solução foram adicionados em recipientes limpos contendo os corpos-de-prova. $\mathrm{O}$ conjunto foi mantido fechado a temperatura $37,0 \pm 1,0^{\circ} \mathrm{C} \mathrm{em}$ estufa (Odontobrás Ind. e Com. Equip. Med. Odont. Ltda., Ribeirão Preto, SP, Brasil).

\section{Períodos de Imersão:}

Buscando analisar tempos prolongados de imersão em soluções higienizadoras para próteses totais, neste trabalho foram realizadas as seguintes simulações:

\subsection{Para resina acrílica e dentes artificiais:}

- 3 anos com imersões diárias de 20 minutos;

- 1 ano e seis meses com imersões diárias de 8 horas (overnight).

\subsection{Para reembasadores resilientes:}

- 3 anos com imersões diárias de 20 minutos;

- 1 ano e seis meses com imersões diárias de 20 minutos;

- 1 ano e seis meses com imersões diárias de 8 horas (overnight). 
Os cálculos para simulação das imersões foram realizados da seguinte forma:

- Para 3 anos com imersões diárias de 20 minutos:

1 hora $=3$ imersões de 20 minutos

24hs $=x$ imersões de 20 minutos

$x=72$ imersões de 20 minutos;

Portanto,

24 horas $(1$ dia $)=72$ imersões de 20 minutos

3 anos $=1095$ dias

Se, 1 dia $=72$ dias de imersões de 20 minutos

$y$ dias $=1095$ dias de imersões de 20 minutos

$y=15$ dias

- Para 1 ano e seis meses com imersões diárias de 20 minutos:

$$
\begin{gathered}
\text { Se, } 15 \text { dias }=3 \text { anos } \\
x \text { dias }=1 \text { ano e } 6 \text { meses } \\
x=7 \text { dias }
\end{gathered}
$$

- Para 1 ano e seis meses com imersões diárias de 8 horas (overnight:

24 horas $=3$ imersões de 8 horas

Portanto,

1 dia = 3 dias de imersões de 8 horas

1 ano e seis meses $=547,5$ dias

Se 1 dia = 3dias de imersões de 8 horas

y dias $=547,5$ dias de imersões de 8 horas

$y=183$ dias

Com base nos cálculos acima demonstrados, as imersões foram realizadas em 7, 15 e 183 dias contínuos. Para os reembasadores resilientes, foi adicionado um período de 7 dias de imersão, visando atender e abranger as indicações de uso de cada material, uma vez que a durabilidade do Elite soft é de 1 ano e 6 meses e a do Mucopren soft é de 3 anos.

Os agentes de imersão foram trocados após percepção de alteração no cheiro ou alteração visual no líquido ( \pm a cada 10 dias). Cabe salientar que a data de validade das soluções ultrapassa este período. 


\section{Realização dos testes}

\subsection{Teste de Dureza}

Para as leituras de dureza Knoop, os corpos-de-prova circulares de resina acrílica foram divididos em 4 quadrantes. Cada quadrante foi submetido a duas leituras de dureza em um Microdurômetro "Microhardness Tester Shimadzu", modelo HMV-2 (Shimadzu Corporation, Kyoto, Japão) (Fig. 12) com uma carga de $25 \mathrm{~g}$ por 5 segundos. A medida final de dureza para cada corpo-de-prova foi o resultado da média dos 8 valores encontrados. A seqüência de leitura foi aleatória por meio de sorteio, de forma que o pesquisador não soubesse de qual resina e a que grupo os corpos-de-prova pertenciam. Os corpos-de-prova dos dentes artificiais foram prensados contra uma base de cera número 9 (Wilson, Polidental Ind. e Com. Ltda., Cotia, SP, Brasil) para que a face palatina planificada ficasse paralela à mesa do microdurômetro e com maior estabilidade, permitindo assim a marcação pela ponta Knoop (Fig.13). Foram realizadas quatro mensurações e calculada a média delas. Os reembasadores resilientes foram submetidos à dureza em um durômetro Shore A (Nishi Tokyo Seimitsu Co Ltd, Tokyo, Japão) (Fig. 14) com os corpos-de-prova posicionados sob a haste vertical do mesmo e submetidos à força de $1 \mathrm{Kg}$ (ASTM 2240-64T). Foram realizadas 8 leituras e calculada a média delas.

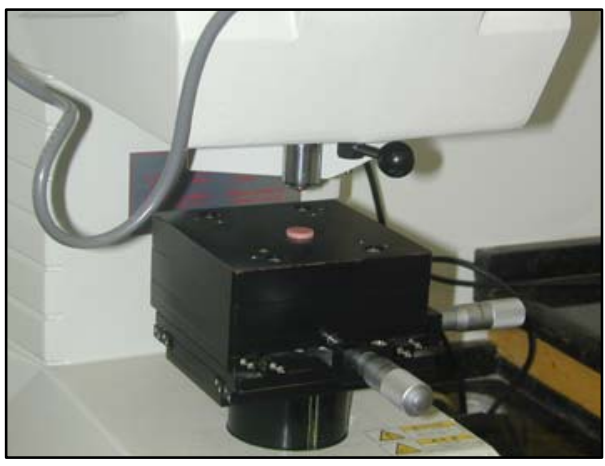

Figura 12 - Corpo-de-prova de resina acrílica posicionado no Microdurômetro Shimadzu para mensuração da dureza Knoop.

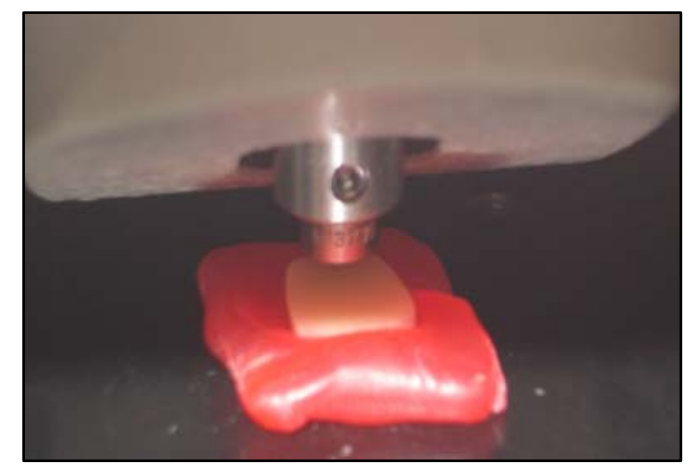

Figura 13 - Corpo-de-prova de dente artificial posicionado no Microdurômetro Shimadzu para mensuração da dureza Knoop.

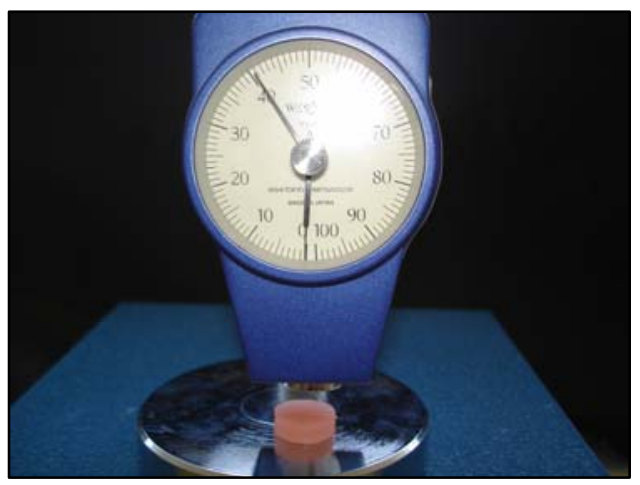

Figura 14 - Corpo-de-prova de reembasador posicionado no durômetro para mensuração da dureza Shore A. 


\subsection{Teste de rugosidade superficial}

Os corpos-de-prova retangulares de resina acrílica tiveram uma de suas superfícies divididas em três áreas iguais. Cada área foi submetida a uma leitura de rugosidade de forma a obter 3 valores de leituras a partir dos quais, foi mensurada a média de rugosidade encontrada no espécime em questão. A seqüência de leitura foi aleatória por meio de sorteio. Os corposde-prova de dentes artificiais foram prensados contra uma cera número 9 (Wilson, Polidental Ind. e Com. Ltda., Cotia, SP, Brasil) para sua estabilização durante as três mensurações da rugosidade. A média destes valores foi calculada. Para os corpos-de-prova de reembasadores resilientes foram realizadas 3 leituras de rugosidade em uma de suas faces, em três regiões diferentes, e a média foi calculada.

As mensurações foram obtidas por meio do aparelho Surface Roughness Tester SJ201P (Mitutoyo Corp, Kawasaki, Japão) com um cut off de $0,8 \mathrm{~mm}$ de forma que a ponta da agulha percorreu uma área de 4,8mm durante cada leitura (Fig. 15).

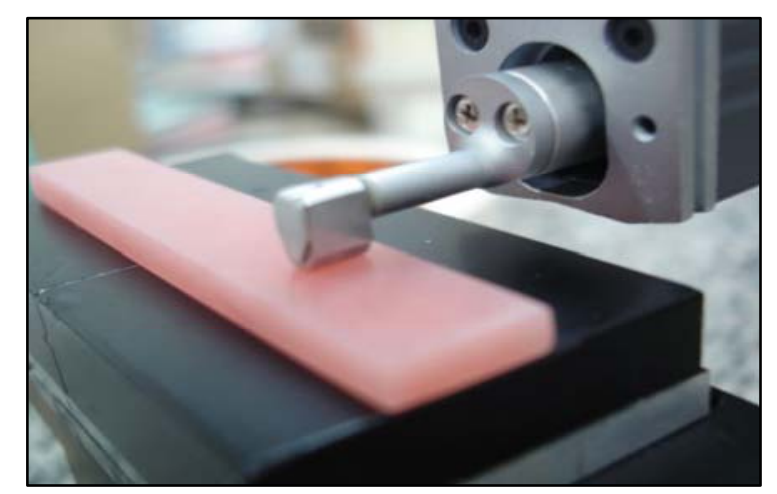

Figura 15 - Corpos-de-prova retangulares de resina acrílica posicionados no rugosímetro Surface Roughness Tester SJ-201P para leitura da rugosidade. 


\subsection{Teste de resistência à flexão}

Os corpos-de-prova de resina acrílica foram submetidos à flexão após os períodos experimentais de imersão. O ensaio foi realizado em Máquina Universal de Ensaios, modelo MEM 2000 (EMIC, São José dos Pinhais, PR, Brasil) (Fig. 16), com velocidade de deformação igual a $5 \mathrm{~mm} / \mathrm{min}$, sendo esses valores constantes. Os espécimes foram submetidos à flexão continuamente até a fratura em um suporte adequado da máquina. Nestas condições, os corpos-de-prova foram submetidos à flexão em 3 pontos, a qual consiste em dois apoios localizados a 50mm um do outro e carga de flexão aplicada no centro do corpode-prova (British Standard Specification for Denture Base Polymers 2487:1989).

A carga de fratura dos corpos-de-prova foi convertida para resistência à flexão por meio da fórmula abaixo e expressa em Megapascais:

$$
\mathrm{R}=\frac{3 \times \mathrm{XX1}}{2 \times \mathrm{B} \mathrm{X} \mathrm{H}^{2}} \text {, sendo: } \mathrm{F}=\text { carga máxima aplicada }(\mathrm{N}) ; 1=\text { distância entre os }
$$

dois pontos de apoio; $\mathrm{B}=$ largura do corpo-de-prova; $\mathrm{H}$ = espessura do corpo-de-prova.

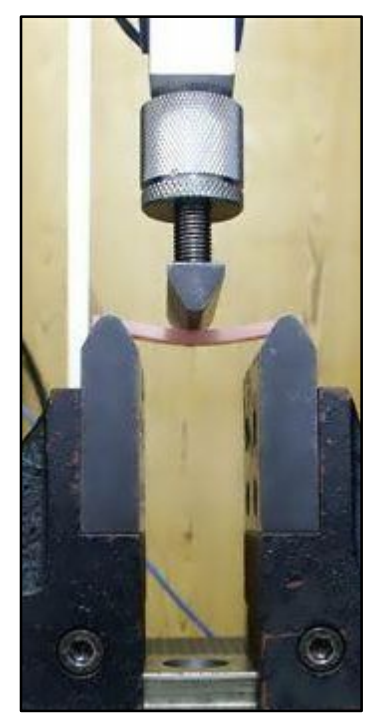

Figura 16 - Corpo-de-prova retangular posicionado na Máquina Universal de Ensaios para ensaio de flexão. 


\subsection{Teste de alteração de cor}

Logo após o polimento e decorridos os tempos de imersões, os corpos-de-prova foram submetidos à leitura de cor utilizando-se um espectrocolorímetro portátil modelo Color Guide 45/0 (BYK-Gardner GmbH - 07/2002, Geretsried, Alemanha) (Fig. 17 e 18), o qual utiliza o sistema de cores Standard Commission Internationale de L'Eclairage (CIE Lab), recomendado pela American Dental Association. Este sistema representa um espaço tridimensional de cor tendo componentes de clareza (L), vermelho-verde (a), e amarelo-azul (b). Um aspecto importante do sistema CIE-Lab é que a diferença de cor entre os tempos pode ser dada usando um parâmetro, $\Delta \mathrm{Eab}$. A alteração de cor entre cada corpo-de-prova, cada uma dada em termos de $\mathrm{L}$, a e b, foi calculada pela seguinte fórmula: $\Delta$ Eab $=\left[(\Delta \mathrm{L})^{2}+\right.$ $\left.(\Delta \mathrm{a})^{2}+(\Delta \mathrm{b})^{2}\right]^{1 / 2}$.

A análise da cor foi realizada com os espécimes de resina acrílica e reembasadores resilientes posicionados no aparelho com sua identificação voltada para a parte frontal do aparelho, onde foi realizada uma linha vertical coincidindo com essa identificação. Esta técnica de posicionamento permitiu que a leitura da cor fosse realizada sempre na mesma posição e na mesma face, antes e após as imersões. Para eliminar a diferença de cor no segundo plano, sobre o corpo-de-prova foi colocado um padrão branco (POWERS; LEPEAK, 1977) utilizado para coleta dos dados e eliminação dos efeitos de diferenças de cor durante as medidas. Para a leitura de cor dos dentes artificiais foi confeccionado um dispositivo em silicone Zetalabor (Zhermack S.P.A, Badia Polesine, Rovigo, Italy) para encaixe do dente com sua face vestibular voltada para a abertura do aparelho (Fig. 19).

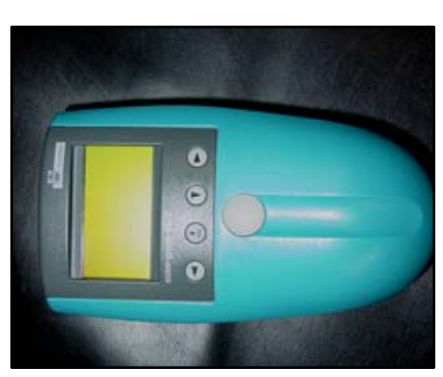

Figura 17 - Espectrocolorímetro Color Guide 45/0 utilizado.

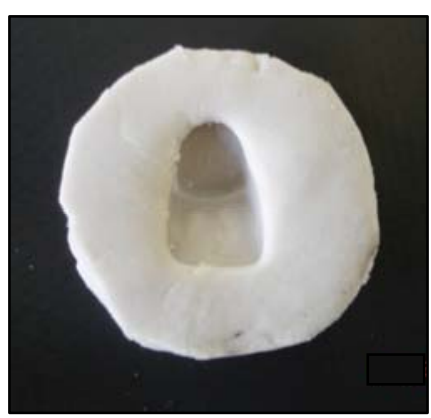

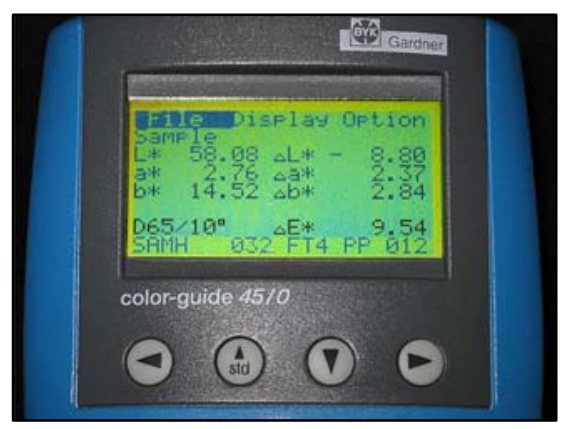

Figura 18 - Visor do espectrocolorímetro utilizado mostrando valores de L, a e b.
Figura 19 - Dispositivo em Zetalabor para posicionamento dos dentes artificiais e leitura da cor. 
Todos os ensaios foram realizados após a obtenção dos corpos-de-prova e após o período de imersão. Após o período de imersão e imediatamente antes da realização dos ensaios, os corpos-de-prova eram removidos das soluções, enxaguados em água corrente e secos com papel absorvente.

\section{Análise dos dados:}

Para todas as variáveis testadas com seus respectivos fatores de variação, a distribuição dos dados apresentou-se normal e homogênea. Sendo assim, empregou-se a análise de Variância a dois fatores seguida pelo teste complementar de Tukey $(\mathrm{P}<0,05)$.

A análise estatística foi realiza com a variação obtida, para cada variável, imediatamente após a confecção dos espécimes (T0) e após os períodos de imersão (T7, T15, T183). Os fatores de variação utilizados foram material e solução. Valores negativos indicam aumento da variável utilizada ao longo do tempo, uma vez que o cálculo da variação foi realizado da seguinte forma:

$\Delta \mathrm{T} 7=\mathrm{T} 0-\mathrm{T} 7 \mathrm{e}$ assim sucessivamente para cada período. 


\section{Resina acrílica}




\subsection{Dureza Knoop}

Na tabela 4 encontram-se as médias $\left(\Delta \mathrm{T}^{15}\right)$ e desvio-padrão (DP), variação da dureza Knoop e dos corpos-de-prova de resina acrílica termopolimerizada em banho de água (RAC) e em microondas (RAM) após o acabamento (T0) e após 15 dias (T15) de imersão.

Tabela 4 - Médias, DP $\left(\Delta \mathrm{T}^{15}\right)$ e variação da dureza Knoop dos corpos-de-prova de RAC e RAM após (T0) e 15 dias (T15) de imersão.

\begin{tabular}{|c|c|c|c|c|c|c|}
\hline Tempo e variação & \multicolumn{2}{|c|}{ T0 } & \multicolumn{2}{|c|}{$\mathrm{T} 15$} & \multirow{2}{*}{$\frac{\Delta^{15}}{\mathrm{RAC}}$} & \multirow{2}{*}{$\frac{\Delta^{15}}{\mathrm{RAM}}$} \\
\hline Solução & $\mathrm{RAC}$ & RAM & $\mathrm{RAC}$ & RAM & & \\
\hline \multirow{10}{*}{ Água } & 30,6 & 24,8 & 19,9 & 22,6 & 10,7 & 2,2 \\
\hline & 31,2 & 24,6 & 20,6 & 27,0 & 10,6 & $-2,4$ \\
\hline & 33,6 & 23,5 & 25,7 & 26,7 & 7,9 & $-3,2$ \\
\hline & 29,0 & 23,7 & 23,4 & 26,7 & 5,6 & -3 \\
\hline & 30,4 & 24,4 & 24,7 & 22,8 & 5,7 & 1,6 \\
\hline & 31,7 & 24,9 & 24,6 & 26,7 & 7,1 & $-1,8$ \\
\hline & 29,5 & 28,9 & 25,2 & 22,6 & 4,3 & 6,3 \\
\hline & 28,5 & 24,4 & 24,0 & 24,6 & 4,5 & $-0,2$ \\
\hline & 27,7 & 24,1 & 21,6 & 20,9 & 6,1 & 3,2 \\
\hline & 32,1 & 24,3 & 24,9 & 25,9 & 7,2 & $-1,6$ \\
\hline Média & 30,43 & 24,76 & 23,46 & 24,65 & 6,97 & 0,11 \\
\hline DP & 1,80 & 1,52 & 2,04 & 2,25 & 2,25 & 3,13 \\
\hline \multirow{10}{*}{ Hipoclorito } & 27,0 & 24,5 & 30,3 & 25,9 & $-3,3$ & $-1,4$ \\
\hline & 25,7 & 28,6 & 26,4 & 25,3 & $-0,7$ & 3,3 \\
\hline & 25,3 & 22,9 & 26,5 & 23,0 & $-1,2$ & $-0,1$ \\
\hline & 27,9 & 25,6 & 30,8 & 24,0 & $-2,9$ & 1,6 \\
\hline & 22,4 & 25,6 & 22,1 & 22,7 & 0,3 & 2,9 \\
\hline & 20,8 & 25,6 & 23,4 & 20,6 & $-23,25$ & $-20,44$ \\
\hline & 29,9 & 23,3 & 26,2 & 23,9 & 3,7 & $-0,6$ \\
\hline & 28,2 & 28,5 & 29,7 & 24,8 & $-1,5$ & 3,7 \\
\hline & 30,5 & 25,6 & 20,9 & 24,6 & 9,6 & 1 \\
\hline & 25,6 & 22,6 & 24,6 & 19,1 & 1 & 3,5 \\
\hline Média & 24,26 & 22,73 & 26,09 & 23,39 & $-1,83$ & $-0,65$ \\
\hline DP & 8,80 & 8,20 & 3,42 & 2,13 & 8,42 & 7,19 \\
\hline \multirow{10}{*}{ Mamona } & 25,8 & 28,1 & 32,5 & 25,6 & $-6,7$ & 11,5 \\
\hline & 26,3 & 25,9 & 37,4 & 26,0 & $-11,1$ & 9,9 \\
\hline & 21,0 & 24,5 & 32,5 & 22,2 & $-11,5$ & 10,3 \\
\hline & 26.6 & 23,6 & 27,5 & 19,4 & $-0,9$ & 4,2 \\
\hline & 27,4 & 24,5 & 30,1 & 23,6 & $-2,7$ & 11,9 \\
\hline & 26,3 & 26,3 & 33,7 & 27,7 & $-7,4$ & 7,6 \\
\hline & 29,9 & 26,0 & 32,7 & 23,2 & $-2,8$ & 7,8 \\
\hline & 25,9 & 25,6 & 39,1 & 20,3 & $-13,2$ & 15,3 \\
\hline & 28,4 & 25,5 & 34,3 & 21,1 & $-5,9$ & 5,4 \\
\hline & 27,4 & 29,5 & 21,6 & 24,2 & $\begin{array}{l}-5,9 \\
5,8\end{array}$ & $\begin{array}{c}J, 4 \\
13,2\end{array}$ \\
\hline Média & 26,5 & 25,95 & 32,14 & 16,24 & $-5,64$ & 9,71 \\
\hline DP & 2,31 & 1,74 & 4,95 & 3,12 & 5,73 & 3,48 \\
\hline
\end{tabular}


A análise de variância aplicada sobre os dados da variação de dureza indicou diferença entre os materiais e para a interação entre os dois fatores analisados, ou seja, material e solução (Tabela 5). A resina acrílica polimerizada em microondas sofreu a maior variação de dureza ao longo do período avaliado (RAC: $\mu=0,52 \pm 6,21$; RAM: $\mu=3,90 \pm 8,04$ ).

Com relação às resinas, houve diferença significante após imersão em água e mamona, sendo que a RAC sofreu maior variação de dureza quando imersa em água e a RAM sofreu maior variação de dureza após imersão em mamona. Analisando as soluções, houve diferença entre elas para o grupo da RAC, sendo que a mamona promoveu aumento da dureza (sinal negativo). No grupo da RAM, a maior variação da dureza ocorreu após a imersão em mamona. A água e o hipoclorito não causaram variação significante (Tabela 6).

Tabela 5 - Teste Anova da variação $\left(\Delta \mathrm{T}^{15}\right)$ de dureza Knoop das resinas acrílica

\begin{tabular}{lclcrr}
\hline Fonte de Variação & Soma de Quadr. & G.L. & Quadr.Médios & ( F ) & Prob.(H0) \\
\hline Material (M) & 171,3660 & 1 & 171,3660 & 12,94 & $0,102 \%$ \\
Solução (S) & 62,2103 & 2 & 31,1051 & 2,35 & $10,323 \%$ \\
M x S & 1255,6569 & 2 & 627,8284 & 47,41 & $0,000 \%$ \\
Resíduo & 715,0564 & 54 & 13,2418 & & \\
Variação total & 2204,2896 & 59 & & & \\
\hline
\end{tabular}

Tabela 6 - Comparação das médias (DP) da variação da dureza $\left(\Delta \mathrm{T}^{15}\right)$ para a interação entre os fatores resina/solução, após 15 dias de imersão.

\begin{tabular}{lccc}
\hline & \multicolumn{1}{c}{ RAC } & RAM & Valor de Tukey \\
\hline Água & $6,97(2,25)^{A a}$ & $0,11(3,13)^{B a}$ & \\
Hipoclorito & $0,24(8,42)$ & \\
Mamona & $-5,64(5,73)^{A c}$ & $1,89(7,19)^{A a}$ & 5,78 \\
\hline
\end{tabular}

Letras maiúsculas: comparação entre colunas; Letras minúsculas: comparação entre linhas. Letras diferentes indicam diferença estatística.

Na tabela 7, encontram-se as médias, desvio-padrão (DP), variação $\left(\Delta \mathrm{T}^{183}\right)$ da dureza Knoop e dos corpos-de-prova de resina acrílica termopolimerizada em banho de água (RAC) e em microondas (RAM) após o acabamento (T0) e após 183 dias (T183) de imersão. 
Tabela 7 - Médias, DP e variação $\left(\Delta \mathrm{T}^{183}\right)$ da dureza Knoop dos corpos-de-prova de RAC e RAM após (T0) e após 183 dias (T183) de imersão.

\begin{tabular}{|c|c|c|c|c|c|c|}
\hline Tempo e variação & & & & & $\Delta^{183}$ & $\Delta^{183}$ \\
\hline Solução & $\mathrm{RAC}$ & RAM & $\mathrm{RAC}$ & RAM & $\mathrm{RAC}$ & RAM \\
\hline & 30,6 & 24,8 & 16,2 & 18,5 & 14,4 & 6,3 \\
\hline & 31,2 & 24,6 & 15,2 & 18,5 & 16 & 6,1 \\
\hline & 33,6 & 23,5 & 17,1 & 19,6 & 16,5 & 3,9 \\
\hline & 29,0 & 23,7 & 12,8 & 23,8 & 16,2 & $-0,1$ \\
\hline Água & 30,4 & 24,4 & 14,9 & 17,5 & 15,5 & 6,9 \\
\hline & 31,7 & 24,9 & 16,3 & 18,3 & 15,4 & 6,6 \\
\hline & 29,5 & 28,9 & 15,6 & 16,1 & 13,9 & 12,8 \\
\hline & 28,5 & 24,4 & 15,0 & 16,8 & 13,5 & 7,6 \\
\hline & 27,7 & 24,1 & 17,9 & 18,5 & 9,8 & 5,6 \\
\hline & 32,1 & 24,3 & 14,9 & 16,8 & 17,2 & 7,5 \\
\hline Média & 30,43 & 24,76 & 15,59 & 18,44 & 14,84 & 6,32 \\
\hline DP & 1,80 & 1,52 & 1,40 & 2,16 & 2,12 & 3,22 \\
\hline & 27,0 & 24,5 & 20,8 & 14,0 & 6,2 & 10,5 \\
\hline & 25,7 & 28,6 & 21,8 & 16,8 & 3,9 & 11,8 \\
\hline & 25,3 & 22,9 & 20,7 & 19,4 & 4,6 & 3,5 \\
\hline & 27,9 & 25,6 & 19,7 & 21,7 & $-19,55$ & $-21,54$ \\
\hline Hipoclorito & 22,4 & 25,6 & 16,1 & 13,9 & 6,3 & 11,7 \\
\hline & 20,8 & 25,6 & 17,6 & 17,7 & 3,2 & 7,9 \\
\hline & 29,9 & 23,3 & 20,3 & 17,3 & 9,6 & 6 \\
\hline & 28,2 & 28,5 & 19,8 & 21,0 & 8,4 & 7,5 \\
\hline & 30,5 & 25,6 & 19,1 & 17,3 & 11,4 & 8,3 \\
\hline & 25,6 & 22,6 & 22,3 & 15,2 & 3,3 & 7,4 \\
\hline Média & 23,56 & 22,74 & 19,82 & 17,43 & 3,74 & 5,31 \\
\hline DP & 8,76 & 8,20 & 1,87 & 2,68 & 8,27 & 9,41 \\
\hline & 25,8 & 28,1 & 21,5 & 16,6 & 4,3 & 11,5 \\
\hline & 26,3 & 25,9 & 21,8 & 16,0 & 4,5 & 9,9 \\
\hline & 21,0 & 24,5 & 25,8 & 14,2 & $-4,8$ & 10,3 \\
\hline & 26.6 & 23,6 & 22,9 & 19,4 & 3,7 & 4,2 \\
\hline & 27,4 & 24,5 & 19,7 & 12,6 & 7,7 & 11,9 \\
\hline Mamona & 26,3 & 26,3 & 21,0 & 18,7 & 5,3 & 7,6 \\
\hline & 29,9 & 26,0 & 22,4 & 18,2 & 7,5 & 7,8 \\
\hline & 25.9 & 25,6 & 23,3 & 10,3 & 2,6 & 15,3 \\
\hline & 28,4 & 25,5 & 26,2 & 20,1 & 2,2 & 5,4 \\
\hline & 27,4 & 29,5 & 23,1 & 16,3 & $\begin{array}{l}2,2 \\
4,3\end{array}$ & $\begin{array}{c}J, 4 \\
13,2\end{array}$ \\
\hline Média & 25,6 & 25,95 & 22,77 & 16,24 & 3,73 & 9,71 \\
\hline DP & 2,30 & 1,74 & 2,02 & 3,12 & 3,50 & 3,48 \\
\hline
\end{tabular}


A análise de variância (Tabela 8) indicou diferença significante para o fator solução e para a interação entre os fatores resina acrílica e soluções de imersão. As soluções de hipoclorito e mamona tiveram influência semelhante na variação da dureza das resinas, diferindo do grupo da água (Tabela 9).

Na tabela 10, a comparação das médias da interação entre os fatores, pode-se perceber que em relação ao material, a resina acrílica polimerizada em microondas teve comportamento diferente da polimerizada de forma convencional quando imersa em água e em mamona. Ao avaliar a solução, nota-se que as soluções de hipoclorito e mamona promoveram alteração somente na resina de polimerização convencional.

Tabela 8 - Teste Anova da variação $\left(\Delta^{183}\right)$ de dureza das resinas acrílicas após 183 dias de imersão

\begin{tabular}{lclcll}
\hline Fonte de Variação & Soma de Quadr. & G.L. & Quadr.Médios & ( F ) & Prob.(H0) \\
\hline Material (M) & 2.4004 & 1 & 2.4004 & 0.26 & $38.123 \%$ \\
Solução (S) & 177.8090 & 2 & 88.9045 & 9.60 & $0.049 \%$ \\
M x S & 548.3312 & 2 & 247.1656 & 29.60 & $0.000 \%$ \\
Resíduo & 500.2028 & 54 & 9.2630 & & \\
Variação total & 1228.7434 & 59 & & & \\
\hline
\end{tabular}

Tabela 9 - Comparação das médias (DP) da variação $\left(\Delta^{183}\right)$ dureza Knoop dos corpos-deprova de resina acrílica: fator solução

\begin{tabular}{|c|c|c|}
\hline & Médias (DP) & Tuckey \\
\hline Água & $10,58(2,67)^{a}$ & \\
\hline Hipoclorito & $7,18(8,42)^{b}$ & 2,93 \\
\hline Mamona & $6,72(3,49)^{b}$ & \\
\hline
\end{tabular}

Letras diferentes indicam diferença estatística.

Tabela 10 - Comparação das médias (DP) da variação da dureza $\left(\Delta^{183}\right)$ para a interação resina acrílica e soluções de imersão.

\begin{tabular}{|c|c|c|c|}
\hline & RAC & RAM & Tukey \\
\hline Água & $14,84(2,12)^{A a}$ & $6,32(3,22)^{B a}$ & \\
\hline Hipoclorito & $6,51(7,88)^{A b}$ & $7,85(8,97)^{A a}$ & 4,18 \\
\hline Mamona & $3.73(3,50)^{A b}$ & $9,71(3,48)^{\mathrm{Ba}}$ & \\
\hline
\end{tabular}

Letras maiúsculas: comparação entre colunas; Letras minúsculas: comparação entre linhas. Letras diferentes indicam diferença estatística. 


\subsection{Rugosidade superficial}

$\mathrm{Na}$ tabela 11 encontram-se as médias, desvio-padrão (DP) e variação $\left(\Delta^{15}\right)$ da rugosidade dos corpos-de-prova de resina acrílica termopolimerizada em banho de água (RAC) e em microondas (RAM) após o acabamento (T0) e após 15 dias (T15) de imersão.

Tabela 11 - Médias, DP e variação $\left(\Delta \mathrm{T}^{15}\right)$ e da rugosidade $(\mu \mathrm{m})$ dos corpos-de-prova de RAC e RAM após 15 dias de imersão.

\begin{tabular}{|c|c|c|c|c|c|c|}
\hline Tempo e variação & & & & & $\left(\Delta^{15}\right)$ & $\left(\Delta^{15}\right)$ \\
\hline Solução & $\mathrm{RAC}$ & RAM & $\mathrm{RAC}$ & RAM & $\mathrm{RAC}$ & RAM \\
\hline & 0,07 & 0,14 & 0,15 & 0,20 & $-0,08$ & $-0,06$ \\
\hline & 0,07 & 0,09 & 0,10 & 0,22 & $-0,03$ & $-0,13$ \\
\hline & 0,10 & 0,10 & 0,15 & 0,17 & $-0,05$ & $-0,07$ \\
\hline & 0,12 & 0,08 & 0,23 & 0,16 & $-0,11$ & $-0,08$ \\
\hline Água & 0,09 & 0,07 & 0,12 & 0,13 & $-0,03$ & $-0,06$ \\
\hline & 0,07 & 0,12 & 0,10 & 0,17 & $-0,03$ & $-0,05$ \\
\hline & 0,10 & 0,09 & 0,07 & 0,15 & 0,03 & $-0,06$ \\
\hline & 0,07 & 0,08 & 0,18 & 0,10 & $-0,11$ & $-0,02$ \\
\hline & 0,10 & 0,11 & 0,20 & 0,20 & $-0,1$ & $-0,09$ \\
\hline & 0,09 & 0,10 & 0,15 & 0,17 & $-0,06$ & $-0,07$ \\
\hline Média & 0,088 & 0,098 & 0,145 & 0,167 & $-0,057$ & $-0,069$ \\
\hline DP & 0,018 & 0,021 & 0,049 & 0,035 & 0,044 & 0,028 \\
\hline & 0,07 & 0,10 & 0,10 & 0,15 & $-0,03$ & $-0,05$ \\
\hline & 0,05 & 0,12 & 0,12 & 0,14 & $-0,07$ & $-0,02$ \\
\hline & 0,08 & 0,09 & 0,15 & 0,12 & $-0,07$ & $-0,03$ \\
\hline & 0,06 & 0,07 & 0,14 & 0,10 & 0,01 & 0,06 \\
\hline Hipoclorito & 0,09 & 0,06 & 0,15 & 0,20 & $-0,06$ & $-0,14$ \\
\hline & 0,13 & 0,10 & 0,15 & 0,18 & $-0,02$ & $-0,08$ \\
\hline & 0,06 & 0,13 & 0,10 & 0,15 & $-0,04$ & $-0,02$ \\
\hline & 0,06 & 0,07 & 0,12 & 0,18 & $-0,06$ & $-0,11$ \\
\hline & 0,09 & 0,08 & 0,12 & 0,19 & $-0,03$ & $-0,11$ \\
\hline & 0,06 & 0,08 & 0,10 & 0,15 & $-0,04$ & $-0,07$ \\
\hline Média & 0,08 & 0,10 & 0,13 & 0,16 & $-0,04$ & $-0,06$ \\
\hline DP & 0,03 & 0,03 & 0,02 & 0,03 & 0,03 & 0,06 \\
\hline & 0,11 & 0,09 & 0,25 & 0,15 & $-0,14$ & $-0,06$ \\
\hline & 0,08 & 0,12 & 0,29 & 0,22 & $-0,21$ & $-0,1$ \\
\hline & 0,07 & 0,13 & 0,24 & 0,23 & $-0,17$ & $-0,1$ \\
\hline & 0,09 & 0,09 & 0,12 & 0,17 & $-0,03$ & $-0,08$ \\
\hline & 0,08 & 0,08 & 0,18 & 0,21 & $-0,1$ & $-0,13$ \\
\hline Mamona & 0,07 & 0,07 & 0,16 & 0,18 & $-0,09$ & $-0,11$ \\
\hline & 0,08 & 0,10 & 0,20 & 0,19 & $-0,12$ & $-0,09$ \\
\hline & 0,08 & 0,10 & 0,20 & 0,24 & $-0,12$ & $-0,14$ \\
\hline & 0,08 & 0,09 & 0,14 & 0,20 & $-0,06$ & $-0,11$ \\
\hline & 0,10 & 0,08 & 0,20 & 0,25 & $-0,1$ & $-0,17$ \\
\hline Média & 0,08 & 0,10 & 0,20 & 0,20 & $-0,11$ & $-0,11$ \\
\hline $\mathrm{DP}$ & 0,01 & 0,02 & 0,05 & 0,03 & 0,05 & 0,03 \\
\hline
\end{tabular}


A análise de variância (Tabela 12) dos dados da variação de rugosidade sofrida pelas resinas acrílicas após imersão nas soluções por 15 dias indicou diferença estatística somente para o fator solução, sendo que a mamona causou a maior variação na rugosidade dos materiais (Tabela 13). Todas promoveram aumento da rugosidade nos corpos-de-prova.

Tabela 12 - Teste Anova da variação $\left(\Delta^{15}\right)$ de rugosidade superficial das resinas acrílicas após 15 dias de imersão.

\begin{tabular}{lclclr}
\hline Fonte de Variação & Soma de Quadr. & G.L. & Quadr.Médios & ( F ) & Prob.(H0) \\
\hline Material (M) & 0.0009 & 1 & 0.0009 & 0.61 & $44.545 \%$ \\
Solução (S) & 0.0349 & 2 & 0.0175 & 12.02 & $0.015 \%$ \\
M x S & 0.0012 & 2 & 0.0006 & 0.43 & $34.020 \%$ \\
Resíduo & 0.0785 & 54 & 0.0015 & & \\
Variação total & 0.1155 & 59 & & & \\
\hline
\end{tabular}

Tabela 13 - Comparação das médias (DP) da rugosidade superficial dos corpos-de-prova após 15 dias de imersão: fator solução

\begin{tabular}{lllc}
\hline & & Médias (DP) & Tuckey \\
\cline { 1 - 1 } Água & $-0,06(0,04)^{a}$ & \\
Hipoclorito & & $-0,05(0,045)^{a}$ & \\
Mamona & & $-0,11(0,04)^{b}$ & \\
\hline
\end{tabular}

Letras diferentes indicam diferença estatística.

Na tabela 14 encontram-se as médias, desvio-padrão (DP) e variação da rugosidade $\left(\Delta^{183}\right)$ dos corpos-de-prova de resina acrílica termopolimerizada em banho de água (RAC) e em microondas (RAM) após o acabamento (T0) e após 183 dias (T183) de imersão. 
Tabela 14 - Médias, DP e variação $\left(\Delta \mathrm{T}^{183}\right)$ e da rugosidade $(\mu \mathrm{m})$ dos corpos-de-prova de RAC e RAM após (T0) e após 183 dias (T183) de imersão.

\begin{tabular}{|c|c|c|c|c|c|c|}
\hline Tempo e variação & & & & & $\Delta \mathrm{T}^{183}$ & $\Delta \mathrm{T}^{183}$ \\
\hline${ }_{\text {Solução }}$ Material & $\mathrm{RAC}$ & RAM & RAC & RAM & $\mathrm{RAC}$ & RAM \\
\hline & 0,04 & 0,09 & 0,05 & 0,12 & $-0,01$ & $-0,03$ \\
\hline & 0,07 & 0,22 & 0,05 & 0,08 & 0,02 & 0,14 \\
\hline & 0,05 & 0,15 & 0,06 & 0,14 & $-0,01$ & 0,01 \\
\hline & 0,06 & 0,13 & 0,08 & 0,08 & $-0,02$ & 0,05 \\
\hline Água & 0,09 & 0,27 & 0,12 & 0,14 & $-0,03$ & 0,13 \\
\hline & 0,20 & 0,27 & 0,30 & 0,11 & $-0,1$ & 0,16 \\
\hline & 0,14 & 0,21 & 0,09 & 0,12 & 0,05 & 0,09 \\
\hline & 0,07 & 0,07 & 0,14 & 0,06 & $-0,07$ & 0,01 \\
\hline & 0,09 & 0,21 & 0,09 & 0,10 & 0 & 0,11 \\
\hline & 0,08 & 0,22 & 0,08 & 0,12 & 0 & 0,1 \\
\hline Média & 0,09 & 0,18 & 0,11 & 0,11 & $-0,02$ & 0,08 \\
\hline DP & 0,05 & 0,07 & 0,07 & 0,03 & 0,04 & 0,06 \\
\hline & 0,20 & 0,14 & 0,22 & 0,18 & $-0,02$ & $-0,04$ \\
\hline & 0,16 & 0,15 & 0,14 & 0,15 & 0,02 & 0 \\
\hline & 0,17 & 0,13 & 0,16 & 0,12 & 0,01 & 0,01 \\
\hline & 0,20 & 0,13 & 0,21 & 0,22 & $-0,06$ & $-0,06$ \\
\hline Hipoclorito & 0,20 & 0,20 & 0,22 & 0,14 & $-0,02$ & 0,06 \\
\hline & 0,18 & 0,22 & 0,18 & 0,13 & 0 & 0,09 \\
\hline & 0,13 & 0,10 & 0,21 & 0,14 & $-0,08$ & $-0,04$ \\
\hline & 0,16 & 0,13 & 0,22 & 0,13 & $-0,06$ & 0 \\
\hline & 0,19 & 0,16 & 0,26 & 0,12 & $-0,07$ & 0,04 \\
\hline & 0,10 & 0,18 & 0,20 & 0,18 & $-0,1$ & 0 \\
\hline Média & 0,16 & 0,16 & 0,20 & 0,15 & $-0,04$ & 0,01 \\
\hline $\mathrm{DP}$ & 0,03 & 0,04 & 0,03 & 0,03 & 0,04 & 0,05 \\
\hline & 0,14 & 0,15 & 0,12 & 0,10 & 0,02 & 0,05 \\
\hline & 0,15 & 0,15 & 0,18 & 0,11 & $-0,03$ & 0,04 \\
\hline & 0,16 & 0,16 & 0,23 & 0,13 & $-0,07$ & 0,03 \\
\hline & 0,15 & 0,14 & 0,13 & 0,10 & 0,02 & 0,04 \\
\hline & 0,15 & 0,16 & 0,11 & 0,16 & 0,04 & 0 \\
\hline Mamona & 0,13 & 0,14 & 0,22 & 0,11 & $-0,09$ & 0,03 \\
\hline & 0,15 & 0,20 & 0,12 & 0,13 & 0,03 & 0,07 \\
\hline & 0,12 & 0,23 & 0,10 & 0,11 & 0,02 & 0,12 \\
\hline & 0,10 & 0,17 & 0,17 & 0,15 & $-0,07$ & 0,02 \\
\hline & 0,20 & 0,17 & 0,15 & 0,15 & 0,05 & 0,02 \\
\hline Média & 0,15 & 0,17 & 0,15 & 0,13 & $-0,01$ & 0,04 \\
\hline DP & 0,03 & 0,03 & 0,05 & 0,02 & 0,05 & 0,03 \\
\hline
\end{tabular}


O teste Anova (Tabela 15) indicou diferença significante entre as resinas e entre as soluções. A resina de microondas sofreu maior variação de rugosidade $(\mu=0,04 \pm 0,04)$ se comparada à resina convencional $(\mu=-0,02 \pm 0,04)$, sendo que esta apresentou um aumento da rugosidade (apontado pelo sinal negativo) e a RAM sofreu redução da rugosidade.

Tabela 15 - Teste Anova dos dados de rugosidade superficial das resinas acrílicas após 183 dias de imersão.

\begin{tabular}{lclcrr}
\hline Fonte de Variação & Soma de Quadr. & G.L. & Quadr.Médios & ( F ) & Prob.(H0) \\
\hline Material (M) & 0.0487 & 1 & 0.0487 & 20.16 & $0.014 \%$ \\
Solução (S) & 0.0182 & 2 & 0.0091 & 3.77 & $2.840 \%$ \\
M x S & 0.0064 & 2 & 0.0032 & 1.32 & $27.548 \%$ \\
Resíduo & 0.1305 & 54 & 0.0024 & & \\
Variação total & 0.2039 & 59 & & & \\
\hline
\end{tabular}

Na tabela 16 encontra-se a comparação das médias (DP) da variação $\left(\Delta \mathrm{T}^{183}\right)$ de rugosidade $(\mu \mathrm{m})$ e o valor de Tukey para o fator solução.

Tabela 16 - Comparação das médias (DP) da variação $\left(\Delta \mathrm{T}^{183}\right)$ rugosidade $(\mu \mathrm{m})$ dos corposde-prova após 183 dias de imersão: fator solução.

\begin{tabular}{|c|c|c|}
\hline & Médias (DP) & Tuckey \\
\hline Água & $0,025(0,05)^{a}$ & \\
\hline Mamona & $0,017(0,045)^{a b}$ & 0,035 \\
\hline Hipoclorito & $-0,015(0,04)^{b}$ & \\
\hline
\end{tabular}

Letras maiúsculas: comparação entre colunas; Letras minúsculas: comparação entre linhas.

Letras diferentes indicam diferença estatística.

A mamona promoveu alteração na rugosidade de forma semelhante às demais soluções, porém o hipoclorito apresentou diferença estatística em relação à água, Os corposde-prova imersos nesta solução apresentaram aumento da rugosidade superficial. 


\subsection{Alteração de cor}

Na tabela 17 estão apresentadas as médias, desvio-padrão (DP) e variação $\left(\Delta \mathrm{T}^{15}\right)$ de cor $(\Delta \mathrm{E})$ dos corpos-de-prova de resina acrílica polimerizados em banho de água (RAC) e em microondas (RAM) após (T0) e após 15 dias (T15) de imersão nas soluções.

Tabela 17 - Médias e desvio-padrão (DP) da variação de cor $\left(\Delta \mathrm{T}^{15}\right)$ das resinas acrílicas após 15 dias de imersão.

\begin{tabular}{|c|c|c|}
\hline Solução & RAC & RAM \\
\hline \multirow{10}{*}{ Água } & 1,22 & 1,60 \\
\hline & 1,48 & 1,47 \\
\hline & 1,10 & 0,51 \\
\hline & 1,20 & 0,62 \\
\hline & 1,19 & 0,46 \\
\hline & 1,26 & 0,77 \\
\hline & 0,95 & 1,18 \\
\hline & 0,68 & 0,76 \\
\hline & 0,66 & 0,62 \\
\hline & 1,66 & 1,90 \\
\hline Média & 1,14 & 0,99 \\
\hline DP & 0,31 & 0,51 \\
\hline \multirow{10}{*}{ Hipoclorito } & 1,12 & 1,02 \\
\hline & 1,11 & 0,70 \\
\hline & 1,04 & 0,99 \\
\hline & 1,09 & 1,12 \\
\hline & 1,20 & 0,98 \\
\hline & 1,10 & 1,84 \\
\hline & 0,94 & 1,19 \\
\hline & 1,26 & 0,78 \\
\hline & 0,69 & 1,14 \\
\hline & 1,10 & 1,11 \\
\hline Média & 1,07 & 1,09 \\
\hline DP & 0,16 & 0,31 \\
\hline \multirow{10}{*}{ Mamona } & 1,28 & 2,83 \\
\hline & 1,47 & 1,20 \\
\hline & 0,71 & 0,62 \\
\hline & 1,03 & 1,05 \\
\hline & 1,42 & 0,70 \\
\hline & 1,38 & 0,87 \\
\hline & 0,90 & 0,98 \\
\hline & 1,38 & 1,56 \\
\hline & 1,22 & 1,55 \\
\hline & 1,29 & 0,80 \\
\hline Média & 1,21 & 1,22 \\
\hline DP & 1,21 & 1,22 \\
\hline
\end{tabular}


A análise de variância (Tabela 18) aplicada sobre os dados da tabela 17 não indicou diferença estatística entre os fatores ou entre a interação dos fatores avaliados.

Tabela 18 - Teste Anova da variação $\left(\Delta \mathrm{T}^{15}\right)$ de cor da resina acrílica após 15 dias de imersão.

\begin{tabular}{lclccc}
\hline Fonte de Variação & Soma de Quadr. & G.L. & Quadr.Médios & ( F ) & Prob.(H0) \\
\hline Material (M) & 0.0242 & 1 & 0.0242 & 0.15 & $29.803 \%$ \\
Solução (S) & 0.2688 & 2 & 0.1344 & 0.83 & $44.357 \%$ \\
M x S & 0.0927 & 2 & 0.0463 & 0.29 & $24.457 \%$ \\
Resíduo & 8.7097 & 54 & 0.1613 & & \\
Variação total & 9.0954 & 59 & & & \\
\hline
\end{tabular}

Na tabela 19 estão apresentadas as médias, desvios-padrão e variação $\left(\Delta \mathrm{T}^{183}\right)$ de cor $(\Delta \mathrm{E})$ dos corpos-de-prova de RAC e RAM após o acabamento (T0) e após 183 dias (T183) de imersão nas soluções. 
Tabela 19 - Médias e desvio-padrão (DP) da variação de cor $\left(\Delta \mathrm{T}^{183}\right)$ da RAC e RAM após 183 dias de imersão.

\begin{tabular}{|c|c|c|}
\hline Solução & RAC & RAM \\
\hline \multirow{10}{*}{ Água } & 3,55 & 0,55 \\
\hline & 1,92 & 1,05 \\
\hline & 2,17 & 0,52 \\
\hline & 3,17 & 0,66 \\
\hline & 0,85 & 0,31 \\
\hline & 1,94 & 0,68 \\
\hline & 1,36 & 0,64 \\
\hline & 2,29 & 0,52 \\
\hline & 1,13 & 0,46 \\
\hline & 1,56 & 1,67 \\
\hline Média & 1,99 & 0,71 \\
\hline DP & 0,85 & 0,39 \\
\hline \multirow{10}{*}{ Hipoclorito } & 2,11 & 1,23 \\
\hline & 1,59 & 0,43 \\
\hline & 0,76 & 2 \\
\hline & 0,79 & 1,31 \\
\hline & 1,47 & 1,22 \\
\hline & 0,54 & 1,05 \\
\hline & 1,07 & 0,86 \\
\hline & 1,57 & 1,2 \\
\hline & 1,28 & 1,94 \\
\hline & 1,21 & 1,98 \\
\hline Média & 1,24 & 1,32 \\
\hline DP & 0,47 & 0,52 \\
\hline \multirow{10}{*}{ Mamona } & 1,81 & 2,89 \\
\hline & 0,91 & 0,31 \\
\hline & 2,15 & 1,26 \\
\hline & 2,83 & 1,02 \\
\hline & 2,47 & 0,58 \\
\hline & 2,06 & 0,53 \\
\hline & 2,55 & 0,69 \\
\hline & 1,71 & 0,76 \\
\hline & 1,89 & 1,66 \\
\hline & 2,31 & 0,5 \\
\hline Média & 2,07 & 1,02 \\
\hline DP & 0,54 & 0,77 \\
\hline
\end{tabular}

Para análise dos dados da tabela 19, foi empregado o teste Anova (Tabela 20), o qual indicou diferença entre as resinas e para a interação entre material/solução. 
Tabela 20 - Teste Anova da variação $\left(\Delta \mathrm{T}^{183}\right)$ de cor da resina acrílica após 183 dias de imersão.

\begin{tabular}{lclccr}
\hline Fonte de Variação & Soma de Quadr. & G.L. & Quadr.Médios & ( F ) & Prob.(H0) \\
\hline Material (M) & 8.4676 & 1 & 8.4676 & 22.54 & $0.008 \%$ \\
Solução (S) & 0.7490 & 2 & 0.3745 & 1.00 & $33.734 \%$ \\
M x S & 5.3636 & 2 & 2.6818 & 7.14 & $0.214 \%$ \\
Resíduo & 20.2855 & 54 & 0.3757 & & \\
Variação total & 34.8657 & 59 & & & \\
\hline
\end{tabular}

A resina acrílica convencional apresentou uma maior variação de cor $(\mu=1,80 \pm 0,62)$ se comparada à resina acrílica polimerizada em microondas $(\mu=1,01 \pm 0,56)$. A comparação das médias (DP) da interação entre os fatores está apresentada na tabela 21.

Tabela 21 - Comparação das médias e desvio-padrão (DP) da variação de cor $\left(\Delta \mathrm{T}^{183}\right)$ da resinas acrílicas após imersão por 183 dias.

\begin{tabular}{|c|c|c|c|}
\hline Solução & RAC & RAM & Tukey \\
\hline Água & $2,00(0,85)^{A a b}$ & $0,70(0,39)^{B a}$ & \\
\hline Hipoclorito & $1,23(0,47)^{A b}$ & $1,32(0,52)^{A a}$ & 0,81 \\
\hline Mamona & $2,06(0,54)^{A a}$ & $1,02(0,77)^{B a}$ & \\
\hline
\end{tabular}

Letras maiúsculas: comparação entre colunas; Letras minúsculas: comparação entre linhas.

Letras diferentes indicam diferença estatística.

Em relação às resinas, houve diferenças entre a RAC e a RAM após imersão na água e na solução de mamona, sendo que a RAC sofreu a maior variação de cor. Quanto ao fator solução, houve diferença entre as soluções somente para o grupo de RAC, sendo que a mamona e o hipoclorito foram estatisticamente semelhantes à água, porém a mamona foi responsável pela maior variação de cor. 


\subsection{Resistência à flexão}

Na tabela 22 estão apresentadas as médias e desvio-padrão (DP) da resistência flexural dos corpos-de-prova de resina acrílica polimerizada em banho de água (RAC) e em microondas (RAM) após (T0) e após 15 dias de imersão nas soluções.

Tabela 22 - Médias e desvio-padrão (DP) da resistência à flexão das RAC e RAM após imersão por 15 dias.

\begin{tabular}{|c|c|c|}
\hline Solução & RAC & RAM \\
\hline \multirow{10}{*}{ Água } & 110,06 & 119,23 \\
\hline & 92,41 & 92,92 \\
\hline & 110,83 & 100,62 \\
\hline & 89,91 & 79,45 \\
\hline & 101,41 & 73,43 \\
\hline & 95,38 & 86,70 \\
\hline & 107,70 & 96,16 \\
\hline & 93,82 & 77,11 \\
\hline & 129,67 & 106,94 \\
\hline & 103,56 & 129,73 \\
\hline Média & 103,48 & 96,23 \\
\hline DP & 11,88 & 18,42 \\
\hline \multirow{10}{*}{ Hipoclorito } & 100,57 & 97,11 \\
\hline & 93,53 & 75,91 \\
\hline & 78,83 & 82,89 \\
\hline & 78,26 & 78,26 \\
\hline & 105,95 & 96,17 \\
\hline & 78,84 & 73,23 \\
\hline & 72,04 & 66,75 \\
\hline & 93,83 & 78,84 \\
\hline & 124,54 & 99,94 \\
\hline & 84,25 & 88,35 \\
\hline Média & 91,06 & 83,75 \\
\hline DP & 16,05 & 11,22 \\
\hline \multirow{10}{*}{ Mamona } & 113,33 & 130,11 \\
\hline & 72,85 & 113,60 \\
\hline & 107,66 & 111,03 \\
\hline & 88,22 & 99,78 \\
\hline & 122,19 & 85,75 \\
\hline & 112,09 & 99,59 \\
\hline & 116,99 & 98,02 \\
\hline & 135,14 & 151,62 \\
\hline & 66,50 & 105,85 \\
\hline & 109,42 & 85,70 \\
\hline Média & 104,44 & 108,11 \\
\hline DP & 21,83 & 20,18 \\
\hline
\end{tabular}


A análise de variância dos dados da tabela 22 indicou diferença estatística entre as soluções analisadas (Tabela 23). A comparação das médias (DP) encontra-se na tabela 24.

Tabela 23 - Teste Anova para os dados de resistência à flexão das resinas acrílicas após 15 dias de imersão.

\begin{tabular}{lclccr}
\hline Fonte de Variação & Soma de Quadr. & G.L. & Quadr.Médios & ( F ) & Prob.(H0) \\
\hline Material (M) & 197.0792 & 1 & 197.0792 & 0.68 & $41.939 \%$ \\
Solução (S) & 3681.1125 & 2 & 1840.5563 & 6.32 & $0.375 \%$ \\
M x S & 398.0708 & 2 & 199.0354 & 0.68 & $48.657 \%$ \\
Resíduo & 15717.4873 & 54 & 291.0646 & & \\
Variação total & 19993.7500 & 59 & & & \\
\hline
\end{tabular}

Tabela 24 - Comparação das médias (DP) da resistência à flexão das resinas acrílicas após imersão por 15 dias: fator solução.

\begin{tabular}{|c|c|c|}
\hline Solução & Médias (DP) & Tuckey \\
\hline Mamona & $106,27(21,0)^{a}$ & \\
\hline Água & $99,86(21,09)^{a b}$ & 13,01 \\
\hline Hipoclorito & $87,4(13,63)^{b}$ & \\
\hline
\end{tabular}

As soluções de mamona e hipoclorito foram diferentes entre si, porém estatisticamente semelhantes ao grupo da água, sendo que a menor média de resistência à flexão foi encontrada para o grupo do hipoclorito.

Na tabela 25 estão apresentadas as médias e desvio-padrão (DP) da resistência à flexão dos corpos-de-prova de resina acrílica polimerizada em banho de água (RAC) e de microondas (RAM) após 183 dias (T183) de imersão nas soluções. 
Tabela 25 - Médias e desvio-padrão (DP) da resistência à flexão das RAC e RAM após imersão 183 dias de imersão.

\begin{tabular}{|c|c|c|}
\hline Solução & RAC & RAM \\
\hline \multirow{10}{*}{ Água } & 75,24 & 89,03 \\
\hline & 71,03 & 75,07 \\
\hline & 91,70 & 83,69 \\
\hline & 84,05 & 99,41 \\
\hline & 83,68 & 77,86 \\
\hline & 85,50 & 74,02 \\
\hline & 78,08 & 96,10 \\
\hline & 87,37 & 76,43 \\
\hline & 95,84 & 92,75 \\
\hline & 79,0 & 89,42 \\
\hline Média & 83,15 & 85,38 \\
\hline DP & 7,53 & 9,25 \\
\hline \multirow{10}{*}{ Hipoclorito } & 91,12 & 59,78 \\
\hline & 82,87 & 83,38 \\
\hline & 92,46 & 60,64 \\
\hline & 76,68 & 82,66 \\
\hline & 72,11 & 66,88 \\
\hline & 93,83 & 73,48 \\
\hline & 73,55 & 51,10 \\
\hline & 102,74 & 70,87 \\
\hline & 86,91 & 70,42 \\
\hline & 91,41 & 56,37 \\
\hline Média & 86,37 & 67,56 \\
\hline DP & 9,90 & 10,74 \\
\hline \multirow{10}{*}{ Mamona } & 65,65 & 80,18 \\
\hline & 54,81 & 57,54 \\
\hline & 95,29 & 63,06 \\
\hline & 57,55 & 73,45 \\
\hline & 76,33 & 49,72 \\
\hline & 84,75 & 71,13 \\
\hline & 72,59 & 52,23 \\
\hline & 74,54 & 55,35 \\
\hline & 71,59 & 83,35 \\
\hline & 59,92 & 53,66 \\
\hline Média & 71,30 & 63,97 \\
\hline $\mathrm{DP}$ & 12,54 & 12,22 \\
\hline
\end{tabular}

O teste Anova foi utilizado para análise dos dados da tabela 25, o qual indicou diferença estatística entre as resinas, entre as soluções e para a interação entre os dois fatores (Tabela 26). 
Tabela 26 - Teste Anova para os dados de resistência à flexão das resinas acrílica após 183 dias de imersão.

\begin{tabular}{lclclc}
\hline Fonte de Variação & Soma de Quadr. & G.L. & Quadr. Médios & ( F ) & Prob.(H0) \\
\hline Material (M) & 969.2427 & 1 & 969.2479 & 8.85 & $0.460 \%$ \\
Solução (S) & 2781.7063 & 2 & 1390.8531 & 12.70 & $0.011 \%$ \\
M x S & 1131.4520 & 2 & 565.7260 & 5.17 & $0.894 \%$ \\
Resíduo & 5913.6875 & 54 & 109.5127 & & \\
Variação total & 10796.0938 & 59 & & & \\
\hline
\end{tabular}

A RAC apresentou valores mais elevados $(\mu=80,34 \pm 10,0)$ de resistência à flexão do que a RAM $(\mu=72,30 \pm 10,73)$. Entre as soluções, a solução de mamona foi estatisticamente diferente das demais (Tabela 27), apresentando a maior média.

Tabela 27 - Comparação das médias (DP) da resistência à flexão das resinas acrílicas após imersão por 183 dias de imersão: fator solução.

\begin{tabular}{lccc}
\hline Solução & Médias (DP) & & Tuckey \\
\cline { 1 - 1 } Mamona & $106,27(21,0)^{a}$ & & 13,01 \\
Água & $99,86(21,09)^{a b}$ & & 13,01 \\
Hipoclorito & $87,4(13,63)^{b}$ & & \\
\hline Letras diferentes indicam diferença estatística.
\end{tabular}

A tabela 28 apresenta a comparação das médias (DP) na interação entre os dois fatores (material e solução).

Tabela 28 - Comparação das médias (DP) da resistência à flexão das resinas acrílicas após imersão por 183 dias: interação entre os materiais resina e solução.

\begin{tabular}{|c|c|c|c|}
\hline Solução & RAC & RAM & Tukey \\
\hline Água & $83,15^{A a}$ & $85,38^{A a}$ & \\
\hline Hipoclorito & $86,56^{A a}$ & $67,55^{B b}$ & 16,63 \\
\hline Mamona & $71,30^{A a}$ & $64,00^{A b}$ & \\
\hline
\end{tabular}

Letras maiúsculas: comparação entre colunas; Letras minúsculas: comparação entre linhas.

Letras diferentes indicam diferença estatística.

Com relação às resinas, houve diferença entre a RAC e RAM somente no grupo do hipoclorito, o qual causou uma menor resistência à flexão da resina de microondas. Analisando as soluções, houve diferença entre a água e as demais soluções no grupo da RAM, sendo que o hipoclorito e a mamona promoveram menores valores de resistência. 


\section{Dentes artificiais}




\subsection{Dureza Knoop}

Na tabela 29 encontram-se as médias, desvio-padrão (DP) e variação $\left(\Delta \mathrm{T}^{15}\right)$ da dureza Knoop dos corpos-de-prova dos dentes artificiais após 15 dias de imersão nas soluções.

Tabela 29 - Médias, DP e variação $\left(\Delta \mathrm{T}^{15}\right)$ da dureza Knoop dos corpos-de-prova de dos dentes artificiais após (T0) e após 15 dias (T15) de imersão.

\begin{tabular}{|c|c|c|c|c|c|c|c|c|c|}
\hline \multirow{2}{*}{$\underbrace{\text { Tempo e variação }}_{\text {Solução }}$ Material } & \multicolumn{3}{|c|}{ T0 } & \multicolumn{3}{|c|}{$\mathrm{T} 15$} & \multirow{2}{*}{$\frac{\left(\Delta \mathrm{T}^{15}\right)}{\text { Vipi }}$} & \multirow{2}{*}{$\frac{\left(\Delta \mathrm{T}^{15}\right)}{\text { Biolux }}$} & \multirow{2}{*}{$\frac{\left(\Delta \mathrm{T}^{15}\right)}{\text { Trilux }}$} \\
\hline & Vipi & Biolux & Trilux & Vipi & Biolux & Trilux & & & \\
\hline \multirow{10}{*}{ Água } & 22,4 & 29,9 & 36,1 & 26,5 & 26,9 & 29,1 & $-4,1$ & 3 & 7 \\
\hline & 25,7 & 32,1 & 37,3 & 25,2 & 18,3 & 35,5 & 0,5 & 13,8 & 1,8 \\
\hline & 22,9 & 26,7 & 25,6 & 26,7 & 22,7 & 24,8 & $-3,8$ & 4 & 0,8 \\
\hline & 32,0 & 25,8 & 23,3 & 21,0 & 28,9 & 25,4 & 11 & $-3,1$ & $-2,1$ \\
\hline & 32,5 & 32,0 & 29,9 & 28,6 & 25,3 & 25,5 & 3,9 & 6,7 & 4,4 \\
\hline & 25,8 & 22,2 & 32,6 & 23,5 & 23,3 & 24,9 & 2,3 & $-1,1$ & 7,7 \\
\hline & 25,8 & 22,8 & 32,8 & 24,3 & 20,7 & 37,5 & 1,5 & 2,1 & $-4,7$ \\
\hline & 32,4 & 24,2 & 34,7 & 28,8 & 23,1 & 19,4 & 3,6 & 1,1 & 15,3 \\
\hline & 27,7 & 25,2 & 32,8 & 23,2 & 26,4 & 29,0 & 4,5 & $-1,2$ & 3,8 \\
\hline & 23,7 & 25,7 & 33,1 & 24,4 & 24,1 & 28,4 & $-0,7$ & 1,6 & 4,7 \\
\hline Média & 27,1 & 26,7 & 31,8 & 25,2 & 23,9 & 27,9 & 1,9 & 2,7 & 3,9 \\
\hline DP & 3,9 & 3,5 & 4,4 & 2,5 & 3,1 & 5,3 & 4,4 & 4,8 & 5,6 \\
\hline \multirow{10}{*}{ Hipoclorito } & 32,0 & 32,4 & 29,3 & 30,3 & 23,2 & 31,2 & 1,7 & 9,2 & $-1,9$ \\
\hline & 27,6 & 33,1 & 32,3 & 37,3 & 20,4 & 29,3 & $-9,7$ & 12,7 & 3 \\
\hline & 30,3 & 33,0 & 30,4 & 37,9 & 23,0 & 26,3 & $-7,6$ & 10 & 4,1 \\
\hline & 29,4 & 26,6 & 27,8 & 24,0 & 19,0 & 24,8 & 5,4 & 7,6 & 3 \\
\hline & 25,1 & 23,5 & 27,7 & 33,6 & 34,1 & 23,5 & $-8,5$ & $-10,6$ & 4,2 \\
\hline & 31,9 & 26,4 & 31,3 & 30,6 & 22,8 & 33,5 & 1,3 & 3,6 & $-2,2$ \\
\hline & 30,4 & 22,4 & 25,5 & 35,8 & 24,3 & 16,1 & $-5,4$ & $-1,9$ & 9,4 \\
\hline & 30,2 & 30,9 & 31,7 & 29,8 & 21,1 & 20,2 & 0,4 & 9,8 & 11,5 \\
\hline & 28,1 & 31,1 & 28,7 & 26,3 & 24,2 & 25,5 & 1,8 & 6,9 & 3,2 \\
\hline & 23,5 & 30,1 & 29,2 & 26,3 & 26,5 & 33,4 & $-2,8$ & 3,6 & $-4,2$ \\
\hline Média & 28,8 & 28,9 & 29,4 & 31,2 & 23,9 & 26,4 & $-2,3$ & 5,1 & 3,0 \\
\hline DP & 2,8 & 3,9 & 2,1 & 4,8 & 4,2 & 5,6 & 5,2 & 6,9 & 4,9 \\
\hline \multirow{10}{*}{ Mamona } & 25,6 & 30,7 & 29,7 & 30,6 & 31,5 & 29,6 & -5 & $-0,8$ & 0,1 \\
\hline & 24,9 & 30,6 & 28,7 & 28,3 & 33,8 & 24,5 & $-3,4$ & $-3,2$ & 4,2 \\
\hline & 24,5 & 27,7 & 25,0 & 23,1 & 25,4 & 37,4 & 1,4 & 2,3 & $-12,4$ \\
\hline & 24,1 & 28,0 & 29,2 & 26,3 & 25 & 26,7 & $-2,2$ & 3 & 2,5 \\
\hline & 23,8 & 29,3 & 32,4 & 23,3 & 27,6 & 31,6 & 0,5 & 1,7 & 0,8 \\
\hline & 22,4 & 23,3 & 28,8 & 40,6 & 31,2 & 29,9 & $-18,2$ & $-7,9$ & $-1,1$ \\
\hline & 26,2 & 27,0 & 26,9 & 26,0 & 25,5 & 34,6 & 0,2 & 1,5 & $-7,7$ \\
\hline & 25,8 & 25,7 & 24,9 & 27,2 & 28,6 & 35,9 & $-1,4$ & $-2,9$ & -11 \\
\hline & 23,4 & 23,7 & 25,9 & 29,0 & 30,3 & 35,6 & $-5,6$ & $-6,6$ & $-9,7$ \\
\hline & 25,0 & 28,2 & 32,3 & 41,9 & 30,8 & 30,5 & $-16,9$ & $-2,6$ & 1,8 \\
\hline Média & 24,6 & 27,4 & 28,4 & 29,6 & 28,9 & 31,6 & $-5,0$ & $-1,5$ & $-3,2$ \\
\hline DP & 1,2 & 2,6 & 2,7 & 6,6 & 3,0 & 4,2 & 6,9 & 3,8 & 6,2 \\
\hline
\end{tabular}


Para análise dos dados da tabela 29, foi empregado o teste Anova (Tabela 30), o qual indicou diferença significante entre dentes e entre as soluções. Não houve interação entre os fatores.

Tabela 30 - Teste Anova para a variação $\left(\Delta \mathrm{T}^{15}\right)$ de dureza Knoop dos dentes artificiais após 15 dias de imersão.

\begin{tabular}{lclccc}
\hline Fonte de Variação & Soma de Quadr. & G.L. & Quadr.Médios & ( F ) & Prob.(H0) \\
\hline Material (M) & 254.4036 & 1 & 127.2018 & 4.17 & $1.846 \%$ \\
Solução (S) & 650.7081 & 2 & 325.3540 & 10.67 & $0.021 \%$ \\
M x S & 121.2792 & 2 & 30.3198 & 0.99 & $41.669 \%$ \\
Resíduo & 2470.4070 & 81 & 30.4989 & & \\
Variação total & 3496.7979 & 89 & & & \\
\hline
\end{tabular}

A comparação das médias (DP) de dureza Knoop dos dentes artificiais após 15 dias de imersão indicou que a marca Vipi sofreu aumento da dureza. No entanto o Biolux foi o que sofreu a maior variação (Tabela 31).

Tabela 31 - Comparação das médias (DP) da variação $\left(\Delta \mathrm{T}^{15}\right)$ de dureza Knoop dos dentes artificiais após imersão por 15 dias: fator dente.

\begin{tabular}{|c|c|c|}
\hline Dentes & Médias (DP) & Tukey \\
\hline Biolux & $2,07(5,16)^{a}$ & \\
\hline Trilux & $1,21(5,56)^{a b}$ & 3,41 \\
\hline Vipi & $-1,84(5,5)^{b}$ & \\
\hline
\end{tabular}

Entre as soluções, a mamona foi diferente das demais, causando a maior variação e o aumento da dureza dos dentes artificiais após 15 dias de imersão (Tabela 32).

Tabela 32 - Comparação das médias (DP) da variação $\left(\Delta \mathrm{T}^{15}\right)$ da dureza Knoop dos dentes artificiais após imersão por 15 dias: fator solução.

\begin{tabular}{|c|c|c|}
\hline Solução & Médias (DP) & Tukey \\
\hline Água & $2,81(4,93)^{a}$ & \multirow{3}{*}{3,41} \\
\hline Hipoclorito & $1,92(5,7)^{a}$ & \\
\hline Mamona & $-3,28(5,63)^{b}$ & \\
\hline
\end{tabular}

Na tabela 33 encontram-se as médias, desvio-padrão (DP) e variação $\left(\Delta \mathrm{T}^{183}\right)$ da dureza Knoop e dos corpos-de-prova dos dentes artificiais após o acabamento e após 183 (T183) dias de imersão. 
Tabela 33 - Médias, DP variação $\left(\Delta \mathrm{T}^{183}\right)$ da dureza Knoop dos corpos-de-prova de dos dentes artificiais após (T0) e após 183 dias (T183) de imersão.

\begin{tabular}{|c|c|c|c|c|c|c|c|c|c|}
\hline Tempo e variação & \multicolumn{3}{|c|}{ T0 } & \multicolumn{3}{|c|}{$\mathrm{T} 183$} & \multirow{2}{*}{$\frac{\left(\Delta \mathrm{T}^{183}\right)}{\text { Vipi }}$} & \multirow{2}{*}{$\begin{array}{c}\left(\Delta \mathrm{T}^{183}\right) \\
\text { Biolu } \\
\mathrm{X}\end{array}$} & \multirow{2}{*}{$\begin{array}{l}\left(\Delta \mathrm{T}^{183}\right) \\
\text { Trilux }\end{array}$} \\
\hline Solução Material & Vipi & Biolux & Trilux & Vipi & Biolux & Trilux & & & \\
\hline \multirow{10}{*}{ Água } & 22,4 & 29,9 & 36,1 & 22,1 & 18,3 & 13,3 & 0,3 & 11,6 & 22,8 \\
\hline & 25,7 & 32,1 & 37,3 & 22,5 & 17,8 & 17,4 & 3,2 & 14,3 & 19,9 \\
\hline & 22,9 & 26,7 & 25,6 & 24,7 & 18,8 & 12,4 & $-1,8$ & 7,9 & 13,2 \\
\hline & 32,0 & 25,8 & 23,3 & 21,3 & 21,4 & 19,3 & 10,7 & 4,4 & 4 \\
\hline & 32,5 & 32,0 & 29,9 & 28,1 & 21,4 & 16,3 & 4,4 & 10,6 & 13,6 \\
\hline & 25,8 & 22,2 & 32,6 & 20,4 & 20,8 & 19,2 & 5,4 & 1,4 & 13,4 \\
\hline & 25,8 & 22,8 & 32,8 & 22,0 & 20,8 & 20,1 & 3,8 & 2 & 12,7 \\
\hline & 32,4 & 24,2 & 34,7 & 26,1 & 19,3 & 16,3 & 6,3 & 4,9 & 18,4 \\
\hline & 27,7 & 25,2 & 32,8 & 22,4 & 19,7 & 12,4 & 5,3 & 5,5 & 20,4 \\
\hline & 23,7 & 25,7 & 33,1 & 24,0 & 21,0 & 19,1 & $-0,3$ & 4,7 & 14 \\
\hline Média & 27,1 & 26,7 & 31,8 & 23,4 & 16,6 & 3,7 & 3,7 & 6,7 & 15,2 \\
\hline DP & 3,9 & 3,5 & 4,4 & 2,4 & 3,0 & 3,6 & 3,6 & 4,2 & 5,4 \\
\hline \multirow{10}{*}{ Hipoclorito } & 32,0 & 32,4 & 29,3 & 21,0 & 17,3 & 19,6 & 11 & 15,1 & 15,2 \\
\hline & 27,6 & 33,1 & 32,3 & 29,5 & 20,2 & 14,4 & $-1,9$ & 12,9 & 1,4 \\
\hline & 30,3 & 33,0 & 30,4 & 28,8 & 19,0 & 14,5 & 1,5 & 14 & 9,7 \\
\hline & 29,4 & 26,6 & 27,8 & 23,5 & 16,1 & 17,3 & 5,9 & 10,5 & 17,9 \\
\hline & 25,1 & 23,5 & 27,7 & 28,6 & 20,1 & 17,7 & $-3,5$ & 3,4 & 15,9 \\
\hline & 31,9 & 26,4 & 31,3 & 25,7 & 19,0 & 17,9 & 6,2 & 7,4 & 10,5 \\
\hline & 30,4 & 22,4 & 25,5 & 27,3 & 19,2 & 14,9 & 3,1 & 3,2 & 10,0 \\
\hline & 30,2 & 30,9 & 31,7 & 22,2 & 19,5 & 17,6 & 8 & 11,4 & 13,4 \\
\hline & 28,1 & 31,1 & 28,7 & 20,6 & 17,3 & 17,9 & 7,5 & 13,8 & 10,6 \\
\hline & 23,5 & 30,1 & 29,2 & 22,3 & 16,1 & 14,6 & 1,2 & 14 & 14,1 \\
\hline Média & 28,8 & 28,9 & 29,4 & 24,9 & 18,4 & 16,6 & 3,9 & 10,6 & 11,9 \\
\hline DP & 2,8 & 3,9 & 2,1 & 3,4 & 1,5 & 1,8 & 4,6 & 4,4 & 4,6 \\
\hline \multirow{10}{*}{ Mamona } & 25,6 & 30,7 & 29,7 & 24,5 & 26,1 & 22,0 & 1,1 & 4,6 & 7,7 \\
\hline & 24,9 & 30,6 & 28,7 & 25,7 & 23,4 & 17,8 & $-0,8$ & 7,2 & 10,9 \\
\hline & 24,5 & 27,7 & 25,0 & 22,0 & 15,7 & 18,6 & 2,5 & 12 & 6,4 \\
\hline & 24,1 & 28,0 & 29,2 & 20,6 & 15,7 & 20,1 & 3,5 & 12,3 & 9,1 \\
\hline & 23,8 & 29,3 & 32,4 & 19,0 & 17,2 & 17,4 & 4,8 & 12,1 & 15 \\
\hline & 22,4 & 23,3 & 28,8 & 25,9 & 26,8 & 20,1 & $-3,5$ & $-3,5$ & 8,7 \\
\hline & 26,2 & 27,0 & 26,9 & 20,4 & 15,4 & 18,2 & 5,8 & 11,6 & 8,7 \\
\hline & 25,8 & 25,7 & 24,9 & 27,0 & 22,1 & 14,4 & $-1,2$ & 3,6 & 10,5 \\
\hline & 23,4 & 23,7 & 25,9 & 26,4 & 19,7 & 15,8 & -3 & 4 & 10,1 \\
\hline & 25,0 & 28,2 & 32,3 & 24,5 & 23,4 & 18,4 & 0,5 & 4,8 & 13,9 \\
\hline Média & 24,6 & 27,4 & 28,4 & 23,6 & 20,5 & 18,3 & 1,0 & 6,9 & 10,1 \\
\hline DP & 1,2 & 2,6 & 2,7 & 2,9 & 4,4 & 2,2 & 3,2 & 5,2 & 2,7 \\
\hline
\end{tabular}


Para análise dos dados da tabela 33 foi empregado o teste Anova indicando diferença estatística entre as diferentes marcas de dentes e entre as soluções (Tabela 34).

Tabela 34 - Teste Anova para variação $\left(\Delta \mathrm{T}^{183}\right)$ de dureza Knoop dos dentes artificiais após 183 dias de imersão.

\begin{tabular}{lclccc}
\hline Fonte de Variação & Soma de Quadr. & G.L. & Quadr.Médios & ( F ) & Prob.(H0) \\
\hline Material (M) & 1450.9496 & 2 & 725.4748 & 46.63 & $0.000 \%$ \\
Solução (S) & 165.1647 & 2 & 82.5824 & 4.85 & $1.025 \%$ \\
M x S & 115.9301 & 4 & 28.9825 & 1.70 & $15.691 \%$ \\
Resíduo & 1378.4951 & 81 & 17.0185 & & \\
Variação total & 3110.5396 & 89 & & & \\
\hline
\end{tabular}

A comparação das médias (DP) da variação da dureza obtida para as diferentes marcas de dentes artificiais indicou diferença entre todas elas após imersão por 183 dias, sendo que o Trilux sofreu a maior variação na dureza, seguido pelo Biolux e Vipi (Tabela 35).

Tabela 35 - Comparação das médias (DP) da variação da dureza dos dentes artificiais após 183 dias de imersão: fator dentes.

\begin{tabular}{lccc}
\hline Dentes & Médias (DP) & & Tukey \\
\cline { 1 - 1 }$n$ & $2,86(3,8)^{a}$ & & \\
Biolux & $8,05(6,8)^{b}$ & & 2,55 \\
Trilux & $12,7(4,2)^{c}$ &
\end{tabular}

A comparação das médias da variação $\left(\Delta \mathrm{T}^{183}\right)$ da dureza para o fator solução (tabela 36) indicou diferença significante entre a solução de mamona e as demais, sendo que os corpos-de-prova imersos em mamona apresentaram a menor variação.

Tabela 36 - Comparação das médias (DP) do fator solução para a dureza dos dentes artificiais após 183 dias de imersão: fator solução.

\begin{tabular}{|c|c|c|}
\hline Solução & Médias (DP) & Tukey \\
\hline Água & $8,57(4,4)^{a}$ & \\
\hline $\begin{array}{l}\text { Hipoclorito } \\
\text { Mamona }\end{array}$ & $\begin{array}{l}9,07(4,5)^{a} \\
6,0(3,7)^{b}\end{array}$ & 2,55 \\
\hline
\end{tabular}




\subsection{Rugosidade superficial}

Na tabela 37 encontram-se as médias, desvio-padrão (DP) e variação $\left(\Delta \mathrm{T}^{15}\right)$ da rugosidade superficial $(\mu \mathrm{m})$ dos corpos-de-prova dos dentes artificiais após 15 dias de imersão nas soluções.

Tabela 37 - Médias, variação $(\Delta \mathrm{T})$ e DP da rugosidade dos corpos-de-prova de dos dentes artificiais após (T0) e após 15 dias (T15) de imersão.

\begin{tabular}{|c|c|c|c|c|c|c|c|c|c|}
\hline \multirow{2}{*}{$\begin{array}{l}\text { Tempo e variação } \\
\text { Solução } \\
\end{array}$} & \multicolumn{3}{|c|}{ T0 } & \multicolumn{3}{|c|}{ T15 } & \multirow{2}{*}{$\begin{array}{l}\Delta \mathrm{T} 0- \\
\mathrm{T} 15 \\
\text { Vipi }\end{array}$} & \multirow{2}{*}{$\begin{array}{c}\Delta \mathrm{T} 0- \\
\mathrm{T} 15 \\
\text { Biolux }\end{array}$} & \multirow{2}{*}{$\begin{array}{c}\Delta \mathrm{T} 0- \\
\mathrm{T} 15 \\
\text { Trilux }\end{array}$} \\
\hline & Vipi & Biolux & Trilux & Vipi & Biolux & Trilux & & & \\
\hline \multirow{10}{*}{ Água } & 0,19 & 0,21 & 0,20 & 0,15 & 0,15 & 0,13 & 0,04 & 0,06 & 0,07 \\
\hline & 0,21 & 0,21 & 0,14 & 0,18 & 0,15 & 0,12 & 0,03 & 0,06 & 0,02 \\
\hline & 0,20 & 0,22 & 0,25 & 0,14 & 0,25 & 0,13 & 0,06 & $-0,03$ & 0,12 \\
\hline & 0,20 & 0,18 & 0,17 & 0,16 & 0,17 & 0,17 & 0,04 & 0,01 & 0 \\
\hline & 0,20 & 0,17 & 0,14 & 0,17 & 0,12 & 0,14 & 0,03 & 0,05 & 0 \\
\hline & 0,17 & 0,19 & 0,19 & 0,15 & 0,16 & 0,13 & 0,02 & 0,03 & 0,06 \\
\hline & 0,21 & 0,17 & 0,14 & 0,14 & 0,14 & 0,14 & 0,07 & 0,03 & 0 \\
\hline & 0,18 & 0,24 & 0,14 & 0,15 & 0,19 & 0,18 & 0,03 & 0,05 & $-0,04$ \\
\hline & 0,14 & 0,27 & 0,15 & 0,15 & 0,15 & 0,13 & $-0,01$ & 0,12 & 0,02 \\
\hline & 0,15 & 0,13 & 0,20 & 0,14 & 0,26 & 0,12 & 0,01 & $-0,13$ & 0,08 \\
\hline \multirow{2}{*}{$\begin{array}{l}\text { Média } \\
\text { DP }\end{array}$} & 0,19 & 0,20 & 0,17 & 0,15 & 0,17 & 0,14 & 0,03 & 0,03 & 0,03 \\
\hline & 0,02 & 0,04 & 0,04 & 0,01 & 0,05 & 0,02 & 0,02 & 0,07 & 0,05 \\
\hline \multirow{10}{*}{ Hipoclorito } & 0,24 & 0,16 & 0,24 & 0,15 & 0,11 & 0,21 & 0,09 & 0,05 & 0,03 \\
\hline & 0,33 & 0,26 & 0,18 & 0,19 & 0,16 & 0,16 & 0,14 & 0,1 & 0,02 \\
\hline & 0,19 & 0,13 & 0,21 & 0,20 & 0,14 & 0,16 & $-0,01$ & $-0,01$ & 0,05 \\
\hline & 0,15 & 0,15 & 0,19 & 0,13 & 0,27 & 0,15 & 0,02 & $-0,12$ & 0,04 \\
\hline & 0,15 & 0,16 & 0,17 & 0,13 & 0,12 & 0,17 & 0,02 & 0,04 & 0 \\
\hline & 0,15 & 0,20 & 0,12 & 0,13 & 0,11 & 0,16 & 0,02 & 0,09 & $-0,04$ \\
\hline & 0,15 & 0,15 & 0,24 & 0,25 & 0,13 & 0,16 & $-0,1$ & 0,02 & 0,08 \\
\hline & 0,18 & 0,18 & 0,18 & 0,13 & 0,15 & 0,16 & 0,05 & 0,03 & 0,02 \\
\hline & 0,28 & 0,16 & 0,21 & 0,12 & 0,15 & 0,19 & 0,16 & 0,01 & 0,02 \\
\hline & 0,18 & 0,12 & 0,16 & 0,20 & 0,16 & 0,15 & $-0,02$ & $-0,04$ & 0,01 \\
\hline \multirow{2}{*}{$\begin{array}{c}\text { Média } \\
\text { DP }\end{array}$} & 0,2 & 0,16 & 0,19 & 0,16 & 0,15 & 0,16 & 0,04 & 0,02 & 0,02 \\
\hline & 0,06 & 0,04 & 0,04 & 0,04 & 0,05 & 0,02 & 0,08 & 0,06 & 0,03 \\
\hline \multirow{10}{*}{ Mamona } & 0,20 & 0,14 & 0,18 & 0,14 & 0,17 & 0,16 & 0,06 & $-0,03$ & 0,02 \\
\hline & 0,16 & 0,14 & 0,17 & 0,26 & 0,19 & 0,20 & $-0,1$ & $-0,05$ & $-0,03$ \\
\hline & 0,17 & 0,22 & 0,24 & 0,15 & 0,23 & 0,32 & 0,02 & $-0,01$ & $-0,08$ \\
\hline & 0,22 & 0,21 & 0,24 & 0,14 & 0,14 & 0,32 & 0,08 & 0,07 & $-0,08$ \\
\hline & 0,26 & 0,17 & 0,18 & 0,14 & 0,30 & 0,26 & 0,12 & $-0,13$ & $-0,08$ \\
\hline & 0,18 & 0,12 & 0,12 & 0,25 & 0,13 & 0,20 & $-0,07$ & $-0,01$ & $-0,08$ \\
\hline & 0,17 & 0,15 & 0,22 & 0,22 & 0,20 & 0,21 & $-0,05$ & $-0,05$ & 0,01 \\
\hline & 0,16 & 0,21 & 0,19 & 0,14 & 0,29 & 0,25 & 0,02 & $-0,08$ & $-0,06$ \\
\hline & 0,15 & 0,23 & 0,27 & 0,16 & 0,23 & 0,19 & $-0,01$ & 0 & 0,08 \\
\hline & 0,27 & 0,14 & 0,17 & 0,15 & 0,17 & 0,21 & 0,12 & $-0,03$ & $-0,04$ \\
\hline Média & 0,19 & 0,17 & 0,20 & 0,18 & 0,21 & 0,23 & 0,02 & $-0,03$ & $-0,03$ \\
\hline DP & 0,04 & 0,04 & 0,04 & 0,05 & 0,06 & 0,05 & 0,08 & 0,05 & 0,05 \\
\hline
\end{tabular}


A análise de variância aplicada sobre os dados da variação de rugosidade da tabela 37 indicou diferença estatística para o fator solução, onde os corpos-de-prova imersos em mamona apresentaram uma menor variação, porém com aumento da rugosidade (Tabela 38).

Tabela 37 - Teste Anova para a variação $\left(\Delta \mathrm{T}^{15}\right)$ de rugosidade superficial dos dentes artificiais após 15 dias de imersão.

\begin{tabular}{lclccc}
\hline Fonte de Variação & Soma de Quadr. & G.L. & Quadr.Médios & ( F ) & Prob.(H0) \\
\hline Material (M) & 0.0120 & 2 & 0.0060 & 1.79 & $17.209 \%$ \\
Solução (S) & 0.0378 & 2 & 0.189 & 5.65 & $0.536 \%$ \\
M x S & 0.0087 & 4 & 0.0022 & 0.65 & $36.711 \%$ \\
Resíduo & 0.2711 & 81 & 0.0033 & & \\
Variação total & 0.3296 & 89 & & & \\
\hline
\end{tabular}

Tabela 38 - Comparação das médias da variação $\left(\Delta \mathrm{T}^{15}\right)$ da rugosidade $(\mu \mathrm{m})$ dos dentes artificiais pós-imersão por 15 dias: fator solução.

\begin{tabular}{|c|c|c|}
\hline Solução & Média (DP) & Tuckey \\
\hline Água & $0,029(0,05)^{a}$ & \multirow{3}{*}{0,035} \\
\hline Hipoclorito & $0,025(0,06)^{a}$ & \\
\hline Mamona & $-0,015(0,06)^{b}$ & \\
\hline
\end{tabular}

Na tabela 39 encontram-se as médias, desvio-padrão (DP) e variação $\left(\Delta \mathrm{T}^{183}\right)$ da rugosidade superficial e dos corpos-de-prova dos dentes artificiais após 183 dias de imersão nas soluções. A análise de variância indicou diferença estatística entre as médias de rugosidade, para o fator material (Tabela 40). 
Tabela 39 - Médias, DP e variação $\left(\Delta \mathrm{T}^{183}\right)$ da rugosidade $(\mu \mathrm{m})$ dos corpos-de-prova dos dentes artificiais após (T0) e após 183 dias (T183) de imersão.

\begin{tabular}{|c|c|c|c|c|c|c|c|c|c|}
\hline \multirow{2}{*}{$\underbrace{\text { Tempo e variação }}_{\text {Solução }}$} & \multicolumn{3}{|c|}{ T0 } & \multicolumn{3}{|c|}{ T183 } & \multirow{2}{*}{$\begin{array}{c}\left(\Delta \mathrm{T}^{183}\right) \\
\text { Vipi } \\
\end{array}$} & \multirow{2}{*}{$\begin{array}{l}\left(\Delta \mathrm{T}^{183}\right) \\
\text { Biolux }\end{array}$} & \multirow{2}{*}{$\begin{array}{l}\left(\Delta \mathrm{T}^{183}\right) \\
\text { Trilux }\end{array}$} \\
\hline & Vipi & Biolux & Trilux & Vipi & Biolux & Trilux & & & \\
\hline \multirow{10}{*}{ Água } & 0,19 & 0,21 & 0,20 & 0,17 & 0,17 & 0,13 & 0,02 & 0,04 & 0,07 \\
\hline & 0,21 & 0,21 & 0,14 & 0,16 & 0,24 & 0,12 & 0,05 & $-0,03$ & 0,02 \\
\hline & 0,20 & 0,22 & 0,25 & 0,16 & 0,26 & 0,14 & 0,04 & $-0,04$ & 0,11 \\
\hline & 0,20 & 0,18 & 0,17 & 0,16 & 0,27 & 0,11 & 0,04 & $-0,09$ & 0,06 \\
\hline & 0,20 & 0,17 & 0,14 & 0,18 & 0,29 & 0,13 & 0,02 & $-0,12$ & 0,01 \\
\hline & 0,17 & 0,19 & 0,19 & 0,13 & 0,22 & 0,14 & 0,04 & $-0,03$ & 0,05 \\
\hline & 0,21 & 0,17 & 0,14 & 0,15 & 0,21 & 0,12 & 0,06 & $-0,04$ & 0,02 \\
\hline & 0,18 & 0,24 & 0,14 & 0,15 & 0,22 & 0,11 & 0,03 & 0,02 & 0,03 \\
\hline & 0,14 & 0,27 & 0,15 & 0,16 & 0,17 & 0,11 & $-0,02$ & 0,1 & 0,04 \\
\hline & 0,15 & 0,13 & 0,20 & 0,14 & 0,27 & 0,12 & 0,01 & $-0,14$ & 0,08 \\
\hline \multirow{2}{*}{$\begin{array}{c}\text { Média } \\
\text { DP }\end{array}$} & 0,19 & 0,20 & 0,17 & 0,16 & 0,23 & 0,12 & 0,03 & $-0,03$ & 0,05 \\
\hline & 0,02 & 0,04 & 0,04 & 0,01 & 0,04 & 0,01 & 0,02 & 0,07 & 0,03 \\
\hline \multirow{10}{*}{ Hipoclorito } & 0,24 & 0,16 & 0,24 & 0,15 & 0,16 & 0,28 & 0,09 & 0 & $-0,04$ \\
\hline & 0,33 & 0,26 & 0,18 & 0,20 & 0,22 & 0,16 & 0,13 & 0,04 & 0,02 \\
\hline & 0,19 & 0,13 & 0,21 & 0,21 & 0,21 & 0,17 & $-0,02$ & $-0,08$ & 0,04 \\
\hline & 0,15 & 0,15 & 0,19 & 0,17 & 0,16 & 0,18 & $-0,02$ & $-0,01$ & 0,01 \\
\hline & 0,15 & 0,16 & 0,17 & 0,18 & 0,20 & 0,16 & $-0,03$ & $-0,04$ & 0,01 \\
\hline & 0,15 & 0,20 & 0,12 & 0,20 & 0,24 & 0,14 & $-0,05$ & $-0,04$ & $-0,02$ \\
\hline & 0,15 & 0,15 & 0,24 & 0,23 & 0,16 & 0,15 & $-0,08$ & $-0,01$ & 0,09 \\
\hline & 0,18 & 0,18 & 0,18 & 0,23 & 0,28 & 0,15 & $-0,05$ & $-0,1$ & 0,03 \\
\hline & 0,28 & 0,16 & 0,21 & 0,21 & 0,16 & 0,20 & 0,07 & 0 & 0,01 \\
\hline & 0,18 & 0,12 & 0,16 & 0,21 & 0,25 & 0,16 & $-0,03$ & $-0,13$ & 0 \\
\hline \multirow{2}{*}{$\begin{array}{l}\text { Média } \\
\text { DP }\end{array}$} & 0,20 & 0,17 & 0,19 & 0,20 & 0,20 & 0,18 & 0,00 & $-0,04$ & 0,02 \\
\hline & 0,06 & 0,04 & 0,04 & 0,03 & 0,04 & 0,04 & 0,07 & 0,05 & 0,04 \\
\hline \multirow{10}{*}{ Mamona } & 0,20 & 0,14 & 0,18 & 0,15 & 0,28 & 0,14 & 0,05 & $-0,14$ & 0,04 \\
\hline & 0,16 & 0,14 & 0,17 & 0,30 & 0,25 & 0,15 & $-0,14$ & $-0,11$ & 0,02 \\
\hline & 0,17 & 0,22 & 0,24 & 0,15 & 0,26 & 0,18 & 0,02 & $-0,04$ & 0,06 \\
\hline & 0,22 & 0,21 & 0,24 & 0,16 & 0,15 & 0,17 & 0,06 & 0,06 & 0,07 \\
\hline & 0,26 & 0,17 & 0,18 & 0,15 & 0,38 & 0,15 & 0,11 & $-0,21$ & 0,03 \\
\hline & 0,18 & 0,12 & 0,12 & 0,22 & 0,16 & 0,16 & $-0,04$ & $-0,04$ & $-0,04$ \\
\hline & 0,17 & 0,15 & 0,22 & 0,21 & 0,20 & 0,20 & $-0,04$ & $-0,05$ & 0,02 \\
\hline & 0,16 & 0,21 & 0,19 & 0,15 & 0,28 & 0,18 & 0,01 & $-0,07$ & 0,01 \\
\hline & 0,15 & 0,23 & 0,27 & 0,19 & 0,29 & 0,17 & $-0,04$ & $-0,06$ & 0,1 \\
\hline & 0,27 & 0,14 & 0,17 & 0,14 & 0,25 & 0,14 & 0,13 & $-0,11$ & 0,03 \\
\hline Média & 0,19 & 0,17 & 0,20 & 0,18 & 0,25 & 0,16 & 0,01 & $-0,08$ & 0,03 \\
\hline DP & 0,04 & 0,04 & 0,04 & 0,05 & 0,07 & 0,02 & 0,08 & 0,07 & 0,04 \\
\hline
\end{tabular}


Tabela 40 - Teste Anova para a variação $\left(\Delta \mathrm{T}^{183}\right)$ de rugosidade superficial dos dentes artificiais após 183 dias de imersão.

\begin{tabular}{lclccl}
\hline Fonte de Variação & Soma de Quadr. & G.L. & Quadr.Médios & ( F ) & Prob.(H0) \\
\hline Material (M) & 0.1099 & 1 & 0.0549 & 17.17 & $0.001 \%$ \\
Solução (S) & 0.0114 & 2 & 0.0057 & 1.78 & $17.379 \%$ \\
M x S & 0.0103 & 2 & 0.0026 & 0.80 & $47.028 \%$ \\
Resíduo & 0.2592 & 81 & 0.0032 & & \\
Variação total & 0.3906 & 89 & & & \\
\hline
\end{tabular}

A comparação das médias (DP) da variação de rugosidade dos corpos-de-prova de dentes artificiais está apresentada na Tabela 41. O dente da marca Biolux apresentou a maior variação da média, bem como aumento de rugosidade ao longo dos 183 dias de imersão.

Tabela 41 - Comparação das médias da rugosidade superficial dos dentes artificiais pósimersão por 183 dias.

\begin{tabular}{|c|c|c|}
\hline Dentes & Média (DP) & Tuckey \\
\hline Vipi & $0,01(0,04)^{a}$ & \\
\hline Biolux & $-0,05(0,08)^{b}$ & 0,035 \\
\hline Trilux & $0,03(0,06)^{a}$ & \\
\hline
\end{tabular}

$\overline{\text { Letras diferentes indicam diferença estatística. }}$ 


\subsection{Alteração de cor}

Na tabela 42 encontram-se as médias e desvio-padrão (DP) da variação de cor $\left(\Delta \mathrm{T}^{15}\right)$ sofrida pelos corpos-de-prova dos dentes artificiais após 15 dias de imersão nas soluções.

Tabela 42 - Médias (DP) da variação $\left(\Delta \mathrm{T}^{15}\right)$ de cor dos corpos-de-prova de dentes artificiais após (T0) e após 15 dias (T15) de imersão.

\begin{tabular}{|c|c|c|c|}
\hline \multirow{2}{*}{ Solução } & \multicolumn{3}{|c|}{$\Delta \mathrm{T}^{15}$} \\
\hline & Vipi & Biolux & Trilux \\
\hline \multirow{10}{*}{ Água } & 1,3 & 1,32 & 1,16 \\
\hline & 1,05 & 0,46 & 1,01 \\
\hline & 2,47 & 0,43 & 0,66 \\
\hline & 1,48 & 1,28 & 1,58 \\
\hline & 1,62 & 1,23 & 1,81 \\
\hline & 1,79 & 0,48 & 1,62 \\
\hline & 2,48 & 0,66 & 1,08 \\
\hline & 1,56 & 0,5 & 1,87 \\
\hline & 2,45 & 1,6 & 1,12 \\
\hline & 1,22 & 1,45 & 0,6 \\
\hline Média & 1,74 & 0,94 & 1,25 \\
\hline $\mathrm{DP}$ & 0,54 & 0,47 & 0,45 \\
\hline \multirow{10}{*}{ Hipoclorito } & 0,48 & 0,48 & 1,55 \\
\hline & 1,17 & 1,17 & 2,49 \\
\hline & 0,55 & 0,55 & 1,36 \\
\hline & 1,65 & 1,65 & 2,29 \\
\hline & 2,12 & 2,12 & 1,81 \\
\hline & 2,12 & 2,12 & 1,25 \\
\hline & 3,12 & 3,12 & 1,37 \\
\hline & 0,2 & 0,2 & 1,83 \\
\hline & 2,12 & 2,12 & 1,01 \\
\hline & 1,37 & 1,37 & 2,12 \\
\hline Média & 1,49 & 1,49 & 1,70 \\
\hline $\mathrm{DP}$ & 0,92 & 0,92 & 0,48 \\
\hline \multirow{10}{*}{ Mamona } & 1,00 & 0,91 & 1,30 \\
\hline & 1,24 & 1,16 & 0,61 \\
\hline & 2,06 & 0,82 & 1,18 \\
\hline & 2,59 & 0,52 & 1,75 \\
\hline & 1,34 & 1,26 & 0,57 \\
\hline & 2,95 & 1,61 & 1,44 \\
\hline & 1,32 & 1,04 & 2,43 \\
\hline & 2,15 & 0,91 & 1,61 \\
\hline & 2,37 & 1,09 & 0,68 \\
\hline & 2,38 & 0,60 & 0,54 \\
\hline Média & 1,94 & 0,99 & 1,21 \\
\hline $\mathrm{DP}$ & 0,67 & 0,32 & 0,62 \\
\hline
\end{tabular}


Para análise dos dados da tabela 42 foi empregado o teste Anova que indicou diferença estatística para o fator material, ou seja, entre as diferentes marcas comerciais de dentes utilizados (Tabela 43).

Tabela 43 - Teste Anova da variação $\left(\Delta \mathrm{T}^{15}\right)$ de cor dos corpos-de-prova dos dentes artificiais após 15 dias de imersão.

\begin{tabular}{lclclr}
\hline Fonte de Variação & Soma de Quadr. & G.L. & Quadr.Médios & ( F ) & Prob.(H0) \\
\hline Material (M) & 8.0579 & 1 & 4.0287 & 12.11 & $0.010 \%$ \\
Solução (S) & 0.1950 & 2 & 0.0975 & 0.29 & $24.912 \%$ \\
M x S & 2.5981 & 2 & 0.6495 & 1.95 & $10.856 \%$ \\
Resíduo & 26.9364 & 81 & 0.3325 & & \\
Variação total & 37.7869 & 89 & & & \\
\hline
\end{tabular}

Após comparação das médias (DP), pode-se perceber que o dente da marca Biolux apresentou a menor variação de cor, sendo estatisticamente diferente dos demais (Tabela 44).

Tabela 44 - Comparação das médias (DP) da variação de cor sofrida pelos corpos-de-prova de dentes artificiais após imersão por 15 dias: fator material.

\begin{tabular}{|c|c|c|}
\hline Dentes & Média (DP) & Tuckey \\
\hline Vipi & $1,72(0,71)^{a}$ & \multirow{3}{*}{0,35} \\
\hline Biolux & $0,99(0,57)^{b}$ & \\
\hline Trilux & $1,40(0,52)^{a}$ & \\
\hline
\end{tabular}

Na tabela 45 encontram-se as médias e desvio-padrão (DP) da variação de cor $\left(\Delta \mathrm{T}^{183}\right)$ sofrida pelos corpos-de-prova dos dentes artificiais após 183 dias de imersão nas soluções. 
Tabela 45 - Médias (DP) da variação $\left(\Delta \mathrm{T}^{183}\right)$ de cor dos corpos-de-prova de dentes artificiais após (T0) e após 183 dias (T183) de imersão.

\begin{tabular}{c|c|c|c}
\hline \multirow{2}{*}{ Solução } & \multicolumn{3}{|c}{$\Delta \mathrm{T}^{183}$} \\
\cline { 2 - 4 } & Vipi & Biolux & Trilux \\
\hline & 0,36 & 1,58 & 0,55 \\
& 0,82 & 1,02 & 0,68 \\
Água & 1,13 & 1,14 & 1,22 \\
& 1,79 & 1,74 & 2,27 \\
& 1,31 & 1,00 & 1,51 \\
& 0,43 & 1,01 & 0,30 \\
& 1,87 & 1,19 & 1,07 \\
& 2,90 & 1,73 & 0,82 \\
Média & 2,08 & 1,45 & 1,18 \\
\hline DP & 1,84 & 0,80 & 2,14 \\
\hline & 1,45 & 1,27 & 1,17 \\
\hline Hipoclorito & 0,80 & 0,33 & 0,65 \\
\hline DP & 1,49 & 1,31 & 0,63 \\
& 1,73 & 1,14 & 2,20 \\
& 0,34 & 2,07 & 1,50 \\
& 1,75 & 1,49 & 1,25 \\
& 2,70 & 1,24 & 1,09 \\
& 6,10 & 1,89 & 1,27 \\
& 1,41 & 1,42 & 1,57 \\
\hline Dédia & 1,35 & 1,71 & 2,25 \\
& 0,89 & 1,73 & 2,13 \\
& 2,05 & 1,51 & 2,42 \\
\hline & 1,60 & 0,30 & 1,63 \\
\hline & 1,45 & 0,86 & 1,30 \\
\hline & 1,81 & 1,44 & 2,54 \\
& 2,55 & 0,90 & 2,20 \\
& 3,89 & 1,32 & 2,17 \\
& 0,95 & 0,68 & 0,61 \\
& 2,28 & 1,84 & 1,68 \\
& 1,20 & 1,86 & 2,13 \\
& 2,32 & 1,19 & 1,26 \\
& 1,19 & 0,99 & 1,07 \\
& & 0,91 & 0,88 \\
\hline \multirow{2}{*}{ Mamona } & 1,20 & 1,58 \\
\hline & 0,41 & 0,65 \\
\hline & &
\end{tabular}


A análise de variância dos dados da tabela 45 não indicou diferença estatística entre os fatores avaliados (Tabela 46).

Tabela 46 - Teste Anova para variação $\left(\Delta \mathrm{T}^{183}\right)$ de cor dos dentes artificiais após 183 dias de imersão.

\begin{tabular}{lclccc}
\hline Fonte de Variação & Soma de Quadr. & G.L. & Quadr.Médios & ( F ) & Prob.(H0) \\
\hline Material (M) & 3.5152 & 2 & 1.7576 & 2.86 & $6.142 \%$ \\
Solução (S) & 3.0362 & 2 & 1.5181 & 2.47 & $8.898 \%$ \\
M x S & 0.8921 & 4 & 0.2230 & 0.36 & $16.454 \%$ \\
Resíduo & 49.7801 & 81 & 0.6146 & & \\
Variação total & 57.2236 & 89 & & & \\
\hline
\end{tabular}




\section{Reembasadores resilientes}




\subsection{Dureza Shore A}

Na tabela 47 estão apresentados os valores da média, desvio-padrão (DP) e variação $\left(\Delta \mathrm{T}^{7}\right)$ da dureza Shore A dos corpos-de-prova de reembasadores após (T0) e após 7 dias (T7) de imersão nas soluções.

Tabela 47 - Médias, DP e variação $\left(\Delta \mathrm{T}^{7}\right)$ da dureza Shore A dos corpos-de-prova de reembasadores resilientes após (T0) e após 7 dias (T7) de imersão.

\begin{tabular}{|c|c|c|c|c|c|c|}
\hline \multirow{2}{*}{$\overbrace{\text { Solução }}^{\text {Tempo e variação }}$} & \multicolumn{2}{|c|}{ T0 } & \multicolumn{2}{|r|}{$\mathrm{T} 7$} & \multirow{2}{*}{$\begin{array}{c}\left(\Delta \mathrm{T}^{7}\right) \\
\text { Elite } \\
\text { Soft }\end{array}$} & \multirow{2}{*}{$\begin{array}{c}\left(\Delta \mathrm{T}^{7}\right) \\
\text { Mucopren } \\
\text { Soft }\end{array}$} \\
\hline & $\begin{array}{l}\text { Elite } \\
\text { Soft }\end{array}$ & $\begin{array}{c}\text { Mucopren } \\
\text { Soft }\end{array}$ & $\begin{array}{l}\text { Elite } \\
\text { Soft }\end{array}$ & $\begin{array}{c}\text { Mucopren } \\
\text { Soft }\end{array}$ & & \\
\hline \multirow{10}{*}{ Água } & 42,3 & 39,8 & 44,5 & 49,2 & $-2,2$ & $-9,4$ \\
\hline & 38,2 & 41,1 & 43,0 & 50,5 & $-4,8$ & $-9,4$ \\
\hline & 40,6 & 42,1 & 43,0 & 50,3 & $-2,4$ & $-8,2$ \\
\hline & 37,6 & 40,9 & 48,5 & 49,3 & $-10,9$ & $-8,4$ \\
\hline & 42,0 & 40,3 & 43,6 & 48,8 & $-1,6$ & $-8,5$ \\
\hline & 38,9 & 41,5 & 39,6 & 50,0 & $-0,7$ & $-8,5$ \\
\hline & 42,5 & 39,1 & 50,0 & 44,1 & $-7,5$ & -5 \\
\hline & 40,3 & 41,6 & 44,3 & 51,2 & -4 & $-9,6$ \\
\hline & 38,7 & 41,6 & 48,7 & 51,2 & -10 & $-9,6$ \\
\hline & 39,2 & 43,4 & 40,6 & 47,3 & $-1,4$ & $-3,9$ \\
\hline Média & 40,03 & 41,14 & 44,58 & 49,19 & $-4,55$ & $-8,05$ \\
\hline DP & 1,69 & 1,15 & 3,29 & 2,03 & 3,50 & 1,88 \\
\hline \multirow{10}{*}{ Hipoclorito } & 42,2 & 33,5 & 48,4 & 47,5 & $-6,2$ & -14 \\
\hline & 41,8 & 34,1 & 50,2 & 48,0 & $-8,4$ & $-13,9$ \\
\hline & 41,8 & 32,6 & 45,0 & 50,2 & $-3,2$ & $-17,6$ \\
\hline & 44,9 & 38,7 & 46,9 & 49,0 & -2 & $-10,3$ \\
\hline & 39,2 & 39,1 & 50,8 & 45,1 & $-11,6$ & -6 \\
\hline & 40,3 & 37,1 & 43,6 & 47,3 & $-3,3$ & $-10,2$ \\
\hline & 43,1 & 40,5 & 47,0 & 48,5 & $-3,9$ & -8 \\
\hline & 42,7 & 39,3 & 50,3 & 49,7 & $-7,6$ & $-10,4$ \\
\hline & 41,7 & 40,6 & 49,0 & 46,1 & $-7,3$ & $-5,5$ \\
\hline & 42,4 & 42,1 & 44,5 & 44,7 & $-2,1$ & $-2,6$ \\
\hline Média & 42,01 & 37,76 & 47,57 & 47,61 & $-5,56$ & $-9,85$ \\
\hline DP & 1,54 & 3,30 & 2,58 & 1,86 & 3,17 & 4,52 \\
\hline \multirow{10}{*}{ Mamona } & 42,0 & 42,5 & 45,0 & 53,0 & -3 & $-10,5$ \\
\hline & 41,2 & 42,6 & 40,0 & 47,5 & 1,2 & $-4,9$ \\
\hline & 37,8 & 40,6 & 47,2 & 48,0 & $-9,4$ & $-7,4$ \\
\hline & 43,0 & 39,1 & 44,5 & 51,5 & $-1,5$ & $-12,4$ \\
\hline & 34,8 & 42,1 & 50,3 & 46,1 & $-15,5$ & -4 \\
\hline & 37,0 & 38,1 & 47,2 & 47,5 & $-10,2$ & $-9,4$ \\
\hline & 40,0 & 39,0 & 42,1 & 50,1 & $-2,1$ & $-11,1$ \\
\hline & 41,8 & 41,5 & 40,0 & 49,0 & 1,8 & $-7,5$ \\
\hline & 39,7 & 42,5 & 44,1 & 48,0 & $-4,4$ & $-5,5$ \\
\hline & 45,5 & 39,0 & 49,0 & 51,0 & $-3,5$ & -12 \\
\hline Média & 40,28 & 40,7 & 44,94 & 49,17 & $-4,66$ & $-8,47$ \\
\hline DP & 2,97 & 1,67 & 3,36 & 2,05 & 5,17 & 2,89 \\
\hline
\end{tabular}


Após a realização da análise de variância (tabela 48), pôde-se perceber que houve diferença significante entre os materiais, sendo que o Mucopren soft $(\mu=-8,79 \pm 7,36)$ sofreu maior variação de dureza se comparado ao Elite soft $(\mu=-4,92 \pm 3,94)$. Cabe salientar que os dois materiais sofreram aumento da dureza.

Tabela 48 - Teste Anova para a variação $\left(\Delta T^{7}\right)$ de dureza Shore A dos reembasadores resilientes após 7 dias de imersão.

\begin{tabular}{lclccc}
\hline Fonte de Variação & Soma de Quadr. & G.L. & Quadr.Médios & ( F ) & Prob.(H0) \\
\hline Material (M) & 224.2627 & 1 & 224.2667 & 15.46 & $0.047 \%$ \\
Solução (S) & 22.2927 & 2 & 11.1463 & 0.77 & $47.282 \%$ \\
M x S & 1.5841 & 2 & 0.7920 & 0.05 & $5.323 \%$ \\
Resíduo & 783.3644 & 54 & 14.5067 & & \\
Variação total & 103.5078 & 59 & & & \\
\hline
\end{tabular}

Na tabela 49 estão apresentados os valores da média, desvio-padrão (DP) e variação $\left(\Delta \mathrm{T}^{15}\right)$ da dureza Shore A dos corpos-de-prova de reembasadores após o acabamento (T0) e após 15 dias (T15) de imersão nas soluções. 
Tabela 49 - Médias, DP e variação $\left(\Delta \mathrm{T}^{15}\right)$ da dureza Shore A dos corpos-de-prova de reembasadores resilientes após (T0) e após 15 dias (T15) de imersão.

\begin{tabular}{|c|c|c|c|c|c|c|}
\hline Tempo e variação & \multicolumn{2}{|c|}{ T0 } & \multicolumn{2}{|c|}{ T15 } & \multirow{2}{*}{$\begin{array}{c}\left(\Delta \mathrm{T}^{15}\right) \\
\text { Elite } \\
\text { Soft }\end{array}$} & \multirow{2}{*}{$\begin{array}{c}\left(\Delta \mathrm{T}^{15}\right) \\
\text { Mucopren } \\
\text { Soft }\end{array}$} \\
\hline Solução Material & $\begin{array}{l}\text { Elite } \\
\text { Soft }\end{array}$ & $\begin{array}{c}\text { Mucopren } \\
\text { Soft }\end{array}$ & $\begin{array}{l}\text { Elite } \\
\text { Soft }\end{array}$ & $\begin{array}{c}\text { Mucopren } \\
\text { Soft }\end{array}$ & & \\
\hline \multirow{10}{*}{ Água } & 42,7 & 39,3 & 46 & 39,2 & $-3,3$ & 0,1 \\
\hline & 38,2 & 43,0 & 33,4 & 44,2 & 4,8 & $-1,2$ \\
\hline & 39,6 & 43,1 & 39,4 & 47,1 & 0,2 & -4 \\
\hline & 45,7 & 41,1 & 43,6 & 37,8 & 2,1 & 3,3 \\
\hline & 44,0 & 41,6 & 48,5 & 40,9 & $-4,5$ & 0,7 \\
\hline & 37,6 & 41,5 & 30,3 & 42,0 & 7,3 & $-0,5$ \\
\hline & 39,2 & 38,1 & 32,2 & 33,0 & 7 & 5,1 \\
\hline & 40,3 & 41,6 & 38,5 & 44,6 & 1,8 & -3 \\
\hline & 38,2 & 39,0 & 35,8 & 41,0 & 2,4 & -2 \\
\hline & 38,2 & 44,1 & 36,7 & 41,8 & $\begin{array}{l}2,4 \\
1,5 \\
\end{array}$ & 2,3 \\
\hline Média & 40,37 & 41,24 & 38,44 & 41,16 & 1,93 & 0,08 \\
\hline DP & 2,80 & 1,94 & 6,02 & 3,93 & 3,87 & 2,85 \\
\hline \multirow{10}{*}{ Hipoclorito } & 45,1 & 30,5 & 47,1 & 47,0 & -2 & $-16,5$ \\
\hline & 44,2 & 34,1 & 46,8 & 49,0 & $-2,6$ & $-14,9$ \\
\hline & 42,8 & 32,6 & 47,3 & 48,3 & $-4,5$ & $-15,7$ \\
\hline & 45,3 & 31,7 & 46,6 & 48,0 & $-1,3$ & $-16,3$ \\
\hline & 35,2 & 39,1 & 41,8 & 49,1 & $-6,6$ & -10 \\
\hline & 41,3 & 38,1 & 45,8 & 48,1 & $-4,5$ & -10 \\
\hline & 44,1 & 40,5 & 49,1 & 48,6 & -5 & $-8,1$ \\
\hline & 37,5 & 39,3 & 42,8 & 47,1 & $-5,3$ & $-7,8$ \\
\hline & 41,7 & 41,6 & 43,5 & 48,0 & $-1,8$ & $-6,4$ \\
\hline & 40,4 & 32,1 & 42,6 & 44,6 & $\begin{array}{r}-2,0 \\
-2,2 \\
\end{array}$ & $-12,5$ \\
\hline Média & 37,65 & 32,17 & 45,34 & 47,78 & $-3,58$ & $-11,82$ \\
\hline DP & 13,59 & 11,97 & 2,47 & 1,31 & 1,81 & 3,84 \\
\hline \multirow{10}{*}{ Mamona } & 42,0 & 45,2 & 43,0 & 49,1 & -1 & $-3,9$ \\
\hline & 43,2 & 43,6 & 40,5 & 47,3 & 2,7 & $-3,7$ \\
\hline & 44,0 & 41,7 & 46,1 & 43,1 & $-2,1$ & $-1,4$ \\
\hline & 42,0 & 40,2 & 40,8 & 40,5 & 1,2 & $-0,3$ \\
\hline & 42,2 & 43,1 & 38,5 & 44,1 & 3,7 & -1 \\
\hline & 40,1 & 37,1 & 36,0 & 37,7 & 4,1 & $-0,6$ \\
\hline & 41,0 & 40,0 & 37,8 & 41,1 & 3,2 & $-1,1$ \\
\hline & 42,7 & 42,5 & 40,5 & 45,6 & 2,2 & $-3,1$ \\
\hline & 39,2 & 40,5 & 35,2 & 38,7 & 4 & 1,8 \\
\hline & 42,5 & 43,7 & 37,5 & 40,1 & 5 & 3,6 \\
\hline Média & 41,89 & 41,76 & 39,59 & 42,73 & 2,3 & $-0,97$ \\
\hline DP & 1,36 & 2,24 & 3,13 & 3,57 & 2,18 & 2,07 \\
\hline
\end{tabular}


A análise de variância dos dados da tabela 49 indicou diferença significante para os fatores material e solução, bem como para a interação entre eles (Tabela 50).

Tabela 50 - Teste Anova para variação $\left(\Delta T^{15}\right)$ da dureza Shore A dos reembasadores resilientes após 15 dias de imersão.

\begin{tabular}{lclccc}
\hline Fonte de Variação & Soma de Quadr. & G.L. & Quadr.Médios & ( F ) & Prob.(H0) \\
\hline Material (M) & 297.4827 & 1 & 297.4827 & 34.29 & $0.001 \%$ \\
Solução (S) & 972.4388 & 2 & 486.2194 & 56.05 & $0.000 \%$ \\
M x S & 112.5824 & 2 & 56.2912 & 6.49 & $0.333 \%$ \\
Resíduo & 468.4700 & 54 & 8.6754 & & \\
Variação total & 1850.9739 & 59 & & & \\
\hline
\end{tabular}

Analisando os fatores de forma isolada, o Mucopren Soft $(\mu=-4,23 \pm 2,62)$ sofreu maior variação na dureza se comparado ao Elite Soft $(\mu=0,21 \pm 2,46)$ ao longo dos 15 . Quanto às soluções, houve diferença estatística na dureza dos corpos-de-prova imersos na solução de hipoclorito $(\mu=-7,70 \pm 3,73)$. A água $(\mu=1,0 \pm 5,3)$ e a mamona $(\mu=0,66 \pm 3,21)$ tiveram comportamentos semelhantes.

$\mathrm{Na}$ tabela 51 encontra-se a comparação das médias da interação entre os fatores material/solução. Houve diferença entre os materiais para o grupo do hipoclorito, sendo que a variação de dureza foi maior para os corpos-de-prova de Mucopren Soft e os dois materiais sofreram aumento da dureza. Entre as soluções, o hipoclorito foi diferente das demais. A mamona não apresentou diferença estatística na dureza dos materiais se comparada à água, entretanto, o Mucopren Soft teve sua dureza aumentada após imersão nesta solução.

Tabela 51 - Comparação das médias (DP) da dureza Shore A dos reembasadores resilientes após imersão por 15 dias.

\begin{tabular}{|c|c|c|c|}
\hline & Elite Soft & Mucopren Soft & Tukey \\
\hline Água & $1,93(3,87)^{A a}$ & $0,08(2,85)^{A a}$ & \multirow{3}{*}{3,89} \\
\hline Hipoclorito & $-3,58(1,81)^{A b}$ & $-11,82(3,84)^{B b}$ & \\
\hline Mamona & $2,30(2,18)^{A a}$ & $-0,97(2,07)^{A a}$ & \\
\hline
\end{tabular}

Letras maiúsculas: comparação entre colunas; Letras minúsculas: comparação entre linhas.

Letras diferentes indicam diferença estatística.

Na tabela 52 estão apresentados os valores da média, desvio-padrão (DP) e variação $\left(\Delta \mathrm{T}^{183}\right)$ da dureza Shore A dos corpos-de-prova de reembasadores após o acabamento (T0) e após 183 dias (T183) de imersão nas soluções. 
Tabela 52 - Médias, DP e variação $\left(\Delta \mathrm{T}^{183}\right)$ da dureza Shore A dos corpos-de-prova de reembasadores resilientes após (T0) e após 183 dias (T183) de imersão.

\begin{tabular}{|c|c|c|c|c|c|c|}
\hline Tempo e variação & \multicolumn{2}{|r|}{ T0 } & \multicolumn{2}{|c|}{ T183 } & \multirow{2}{*}{$\begin{array}{c}\left(\Delta \mathrm{T}^{183}\right) \\
\text { Elite } \\
\text { Soft }\end{array}$} & \multirow{2}{*}{$\begin{array}{c}\left(\Delta \mathrm{T}^{183}\right) \\
\text { Mucopren } \\
\text { Soft }\end{array}$} \\
\hline Solução & $\begin{array}{l}\text { Elite } \\
\text { Soft }\end{array}$ & $\begin{array}{l}\text { Mucopren } \\
\text { Soft }\end{array}$ & $\begin{array}{l}\text { Elite } \\
\text { Soft }\end{array}$ & $\begin{array}{l}\text { Mucopren } \\
\text { Soft }\end{array}$ & & \\
\hline \multirow{10}{*}{ Água } & 42,7 & 39,3 & 46,5 & 50,8 & $-3,8$ & $-11,5$ \\
\hline & 38,2 & 43 & 41,0 & 52,5 & $-2,8$ & $-9,5$ \\
\hline & 39,6 & 43,1 & 45,0 & 50,5 & $-5,4$ & $-7,4$ \\
\hline & 45,7 & 41,1 & 46,3 & 48,3 & $-0,6$ & $-7,2$ \\
\hline & 44,0 & 41,6 & 43,6 & 48,0 & 0,4 & $-6,4$ \\
\hline & 37,6 & 41,5 & 40,6 & 46,0 & -3 & $-4,5$ \\
\hline & 39,2 & 38,1 & 42,6 & 43,1 & $-3,4$ & -5 \\
\hline & 40,3 & 41,6 & 42,3 & 53,3 & -2 & $-11,7$ \\
\hline & 38,2 & 39 & 39,1 & 49,1 & $-0,9$ & $-10,1$ \\
\hline & 38,2 & 44,1 & 39,6 & 46,3 & $-1,4$ & $-2,2$ \\
\hline Média & 40,37 & 41,24 & 42,66 & 48,79 & $-2,29$ & $-7,55$ \\
\hline DP & 2,66 & 1,84 & 2,52 & 2,97 & 1,64 & 2,98 \\
\hline \multirow{10}{*}{ Hipoclorito } & 45,1 & 30,5 & 48,0 & 45,5 & $-2,9$ & -15 \\
\hline & 44,2 & 34,1 & 50,8 & 47,0 & $-6,6$ & $-12,9$ \\
\hline & 42,8 & 32,6 & 48,0 & 50,5 & $-5,2$ & $-17,9$ \\
\hline & 45,3 & 31,7 & 46,6 & 47,0 & $-1,3$ & $-15,3$ \\
\hline & 35,2 & 39,1 & 51,8 & 48,1 & $-16,6$ & -9 \\
\hline & 41,3 & 38,1 & 42,6 & 47,1 & $-1,3$ & -9 \\
\hline & 44,1 & 40,5 & 47,0 & 46,6 & $-2,9$ & $-6,1$ \\
\hline & 37,5 & 39,3 & 46,6 & 49,1 & $-9,1$ & $-9,8$ \\
\hline & 41,7 & 41,6 & 49,0 & 48,1 & $-7,3$ & $-6,5$ \\
\hline & 40,4 & 32,1 & 44,5 & 44,1 & $-4,1$ & -12 \\
\hline Média & 38,26 & 32,07 & 47,49 & 47,31 & $-5,73$ & $-11,35$ \\
\hline $\mathrm{DP}$ & 13,60 & 11,91 & 2,73 & 1,79 & 4,61 & 3,93 \\
\hline \multirow{10}{*}{ Mamona } & 42,0 & 45,2 & 46,0 & 51,8 & -4 & $-6,6$ \\
\hline & 43,2 & 43,6 & 40,8 & 48,5 & 2,4 & $-4,9$ \\
\hline & 44,0 & 41,7 & 45,5 & 49,0 & $-1,5$ & $-7,3$ \\
\hline & 42,0 & 40,2 & 46,5 & 52,0 & $-4,5$ & $-11,8$ \\
\hline & 42,2 & 43,1 & 43,8 & 49,1 & $-1,6$ & -6 \\
\hline & 40,1 & 37,1 & 43,1 & 48,5 & -3 & $-11,4$ \\
\hline & 41,0 & 40,0 & 44,1 & 49,1 & $-3,1$ & $-9,1$ \\
\hline & 42,7 & 42,5 & 38,0 & 48,0 & 4,7 & $-5,5$ \\
\hline & 39,2 & 40,5 & 46,1 & 48,0 & $-6,9$ & $-7,5$ \\
\hline & 42,5 & 43,7 & 42,0 & 48,0 & $\begin{array}{l}-0,9 \\
0,5\end{array}$ & $\begin{array}{l}-1,3 \\
-4,3\end{array}$ \\
\hline Média & 41,89 & 41,76 & 43,59 & 49,20 & $-1,70$ & $-7,44$ \\
\hline DP & 1,44 & 2,36 & 2,71 & 1,49 & 3,44 & 2,59 \\
\hline
\end{tabular}

A análise de variância dos dados da variação da dureza da tabela 52 indicou diferença entre os fatores bem como para a interação material/solução (Tabela 53). 
Tabela 53 - Teste Anova para a variação $\left(\Delta \mathrm{T}^{183}\right)$ dureza Shore A dos reembasadores resilientes após 183 dias de imersão.

\begin{tabular}{lclcrc}
\hline Fonte de Variação & Soma de Quadr. & G.L. & Quadr.Médios & ( F ) & Prob.(H0) \\
\hline Material (M) & 460.3747 & 1 & 460.3747 & 40.57 & $0.000 \%$ \\
Solução (S) & 193.2524 & 2 & 96.6262 & 8.51 & $0.090 \%$ \\
M x S & 0.6230 & 2 & 0.3115 & 0.03 & $2.643 \%$ \\
Resíduo & 612.8049 & 54 & 11.3482 & & \\
Variação total & 1267.0549 & 59 & & & \\
\hline
\end{tabular}

Após 183 dias de imersão, o Mucopren Soft $(\mu=-8,78 \pm 3,16)$ sofreu maior variação na dureza quando comparado ao Elite Soft $(\mu=-3,24 \pm 3,23)$, sendo que os dois grupos tiveram a dureza aumentada. Entre as soluções, os corpos-de-prova imersos no hipoclorito $(\mu=-$ $8,54 \pm 4,27)$ apresentaram variação na dureza significantemente maior do que aqueles imersos em água $(\mu=-4,92 \pm 3,13)$ ou mamona $(\mu=-4,57 \pm 3,01)$. A comparação das médias da interação entre os dois fatores encontra-se na tabela 54.

Tabela 54 - Comparação das médias (DP) da variação $\left(\Delta \mathrm{T}^{183}\right)$ da dureza Shore A dos reembasadores resilientes após imersão por 183 dias.

\begin{tabular}{|c|c|c|c|}
\hline Solução & Elite Soft & Mucopren Soft & Tukey \\
\hline Água & $-2,29(1,64)^{A a}$ & $-7,55(3,0)^{B a}$ & \\
\hline Hipoclorito & $-5,73(4,61)^{A a}$ & $-11,35(3,93)^{B a}$ & 4,45 \\
\hline Mamona & $-1,7(3,44)^{A b}$ & $-7,44(2,6)^{B a}$ & \\
\hline
\end{tabular}

Letras maiúsculas: comparação entre colunas; Letras minúsculas: comparação entre linhas. Letras diferentes indicam diferença estatística.

Entre os materiais, houve diferença, sendo que a maior variação de dureza foi apresentada pelo Mucopren Soft em todas as soluções. Comparando as soluções, a mamona apresentou resultado estatisticamente diferente das demais, somente para o Elite Soft, gerando a menor variação. Todos os materiais sofreram aumento da dureza. 


\subsection{Rugosidade superficial}

Na tabela 55 estão apresentados os valores da média, desvio-padrão (DP) e variação $\left(\Delta \mathrm{T}^{7}\right)$ rugosidade $(\mu \mathrm{m})$ dos corpos-de-prova de reembasadores após (T0) e após 7 dias (T7) de imersão nas soluções.

Tabela 55 - Médias, desvio-padrão (DP) e variação da rugosidade superficial $(\mu \mathrm{m})$ dos corpos-de-prova de reembasadores resilientes após 7 dias (T7) de imersão.

\begin{tabular}{|c|c|c|c|c|c|c|}
\hline Tempo e variação & & $\overline{\Gamma 0}$ & & & $\left(\Delta T^{7}\right)$ & $\left(\Delta T^{7}\right)$ \\
\hline Solução $\quad$ Material & $\begin{array}{l}\text { Elite } \\
\text { Soft }\end{array}$ & $\begin{array}{l}\text { Mucopren } \\
\text { Soft }\end{array}$ & $\begin{array}{l}\text { Elite } \\
\text { Soft }\end{array}$ & $\begin{array}{l}\text { Mucopren } \\
\text { Soft }\end{array}$ & $\begin{array}{l}\text { Elite } \\
\text { Soft }\end{array}$ & $\begin{array}{l}\text { Mucopren } \\
\text { Soft }\end{array}$ \\
\hline & 1,39 & 1,92 & 1,20 & 1,89 & 0,19 & 0,03 \\
\hline & 1,28 & 1,23 & 1,30 & 1,79 & $-0,02$ & $-0,56$ \\
\hline & 1,00 & 1,54 & 1,10 & 1,14 & $-0,1$ & 0,4 \\
\hline & 1,07 & 1,28 & 0,91 & 1,22 & 0,16 & 0,06 \\
\hline Água & 1,33 & 1,27 & 1,20 & 1,12 & 0,13 & 0,15 \\
\hline & 1,49 & 1,03 & 1,50 & 1,90 & $-0,01$ & $-0,87$ \\
\hline & 1,74 & 1,34 & 1,10 & 1,93 & 0,64 & $-0,59$ \\
\hline & 1,34 & 1,39 & 1,20 & 1,74 & 0,14 & $-0,35$ \\
\hline & 1,15 & 0,95 & 1,00 & 0,90 & 0,15 & 0,05 \\
\hline & 1,15 & 0,93 & 0,98 & 1,30 & 0,17 & $-0,37$ \\
\hline Média & 1,29 & 1,29 & 1,15 & 1,49 & 0,14 & $-0,20$ \\
\hline $\mathrm{DP}$ & 0,22 & 0,30 & 0,17 & 0,39 & 0,20 & 0,40 \\
\hline & 1,18 & 1,12 & 0,86 & 1,27 & 0,32 & $-0,15$ \\
\hline & 1,22 & 1,65 & 1,00 & 1,80 & 0,22 & $-0,15$ \\
\hline & 1,11 & 1,88 & 1,10 & 1,30 & 0,01 & 0,58 \\
\hline & 1,15 & 1,22 & 1,00 & 1,39 & 0,15 & $-0,17$ \\
\hline Hipoclorito & 1,52 & 1,02 & 1,30 & 1,54 & 0,22 & $-0,52$ \\
\hline & 1,60 & 1,14 & 1,22 & 1,50 & 0,38 & $-0,36$ \\
\hline & 1,14 & 1,21 & 1,12 & 1,74 & 0,02 & $-0,53$ \\
\hline & 1,35 & 1,15 & 1,00 & 0,90 & 0,35 & 0,25 \\
\hline & 1,21 & 1,10 & 1,15 & 1,11 & 0,06 & $-0,01$ \\
\hline & 1,25 & 1,39 & 1,27 & 1,49 & $-0,02$ & $-0,1$ \\
\hline Média & 1,27 & 1,29 & 1,10 & 1,40 & 0,17 & $-0,12$ \\
\hline DP & 0,16 & 0,26 & 0,13 & 0,26 & 0,14 & 0,31 \\
\hline & 1,07 & 0,96 & 1,23 & 0,98 & $-0,16$ & $-0,02$ \\
\hline & 1,00 & 1,30 & 1,39 & 1,25 & $-0,39$ & 0,05 \\
\hline & 1,10 & 1,38 & 1,00 & 1,46 & 0,1 & $-0,08$ \\
\hline & 0,98 & 1,61 & 1,22 & 0,95 & $-0,24$ & 0,66 \\
\hline & 1,17 & 1,20 & 1,15 & 1,32 & 0,02 & $-0,12$ \\
\hline Mamona & 1,01 & 1,63 & 1,00 & 1,33 & 0,01 & 0,3 \\
\hline & 1,26 & 1,33 & 1,17 & 1,25 & 0,09 & 0,08 \\
\hline & 1,05 & 1,50 & 1,29 & 1,14 & $-0,24$ & 0,36 \\
\hline & 1,23 & 1,36 & 1,18 & 1,62 & 0,05 & $-0,26$ \\
\hline & 0,90 & 1,35 & 0,89 & 174 & 0,01 & $-0,39$ \\
\hline Média & 1,08 & 1,36 & 1,15 & 1,30 & $-0,08$ & 0,06 \\
\hline DP & 0,11 & 0,19 & 0,14 & 0,24 & 0,15 & 0,28 \\
\hline
\end{tabular}


Para análise dos dados da tabela 55, foi empregado o teste Anova (Tabela 56), o qual indicou diferença significante para o fator material e para a interação material e solução.

Tabela 56 - Teste Anova para a rugosidade dos reembasadores resilientes após 7 dias de imersão.

\begin{tabular}{lclccc}
\hline Fonte de Variação & Soma de Quadr. & G.L. & Quadr.Médios & ( F ) & Prob.(H0) \\
\hline Material (M) & 0.4234 & 1 & 0.4234 & 5.49 & $2.156 \%$ \\
Solução (S) & 0.0338 & 2 & 0.0169 & 0.22 & $19.358 \%$ \\
M x S & 0.6894 & 2 & 0.3447 & 4.47 & $1.572 \%$ \\
Resíduo & 4.1658 & 54 & 0.0771 & & \\
Variação total & 5.3124 & 59 & & & \\
\hline
\end{tabular}

O reembasador Mucopren soft $(\mu=-0,09 \pm 0,80)$ apresentou aumento e maior variação da rugosidade superficial que o Elite soft $(\mu=0,08 \pm 0,16)$. A comparação das médias da interação encontra-se na tabela 57.

Tabela 57 - Comparação das médias (DP) da variação $\left(\Delta \mathrm{T}^{7}\right)$ da rugosidade $(\mu \mathrm{m})$ dos corposde-prova após imersão por 7 dias.

\begin{tabular}{|c|c|c|c|}
\hline Solução & Elite Soft & Mucopren Soft & Tukey \\
\hline Água & $0,14(0,20)^{A a}$ & $-0,20(0,40)^{B a}$ & \\
\hline Hipoclorito & $0,17(0,14)^{A a}$ & $-0,12(0,31)^{\text {ва }}$ & 0,36 \\
\hline Mamona & $-0,08(0,15)^{A b}$ & $0,06(0,28)^{A b}$ & \\
\hline
\end{tabular}

Quanto aos materiais, houve diferença estatística entre o Elite soft e o Mucopren soft após imersão em água e hipoclorito, onde o Mucopren sofreu aumento da rugosidade. A solução de mamona causou a menor variação na rugosidade dos materiais quando comparada aos demais.

Na tabela 58 estão apresentados os valores da média, desvio-padrão (DP) e variação $\left(\Delta \mathrm{T}^{15}\right)$ rugosidade dos corpos-de-prova de reembasadores após o acabamento (T0) e após 15 dias (T15) de imersão nas soluções. 
Tabela 58 - Médias, desvio-padrão (DP) e variação $\left(\Delta \mathrm{T}^{15}\right)$ da rugosidade superficial $(\mu \mathrm{m})$ dos corpos-de-prova de reembasadores resilientes após 15 dias (T15) de imersão.

\begin{tabular}{|c|c|c|c|c|c|c|}
\hline Tempo e variação & & 0 & & & $\left(\Delta \mathrm{T}^{15}\right)$ & $\left(\Delta \mathrm{T}^{15}\right)$ \\
\hline Solução & $\begin{array}{l}\text { Elite } \\
\text { Soft }\end{array}$ & $\begin{array}{l}\text { Mucopren } \\
\text { Soft }\end{array}$ & $\begin{array}{l}\text { Elite } \\
\text { Soft }\end{array}$ & $\begin{array}{l}\text { Mucopren } \\
\text { Soft }\end{array}$ & $\begin{array}{l}\text { Elite } \\
\text { Soft }\end{array}$ & $\begin{array}{l}\text { Mucopren } \\
\text { Soft }\end{array}$ \\
\hline & 1,99 & 1,93 & 2,90 & 1,88 & $-0,91$ & 0,05 \\
\hline & 1,99 & 1,06 & 2,90 & 1,99 & $-0,91$ & $-0,93$ \\
\hline & 0,76 & 1,53 & 2,70 & 1,04 & $-1,94$ & 0,49 \\
\hline & 0,83 & 1,58 & 1,50 & 1,22 & $-0,67$ & 0,36 \\
\hline Água & 1,66 & 1,52 & 1,90 & 1,18 & $-0,24$ & 0,34 \\
\hline & 1,86 & 1,11 & 1,60 & 1,20 & 0,26 & $-0,09$ \\
\hline & 2,19 & 2,34 & 2,80 & 2,97 & $-0,61$ & $-0,63$ \\
\hline & 1,69 & 1,99 & 1,90 & 1,74 & $-0,21$ & 0,25 \\
\hline & 1,66 & 0,96 & 2,80 & 1,07 & $-1,14$ & $-0,11$ \\
\hline & 2,10 & 0,93 & 2,60 & 1,32 & $\begin{array}{c}-1,14 \\
-0,5\end{array}$ & $\begin{array}{l}-0,11 \\
-0,39\end{array}$ \\
\hline Média & 1,67 & 1,50 & 2,36 & 1,56 & $-0,69$ & $-0,07$ \\
\hline $\mathrm{DP}$ & 0,50 & 0,48 & 0,57 & 0,60 & 0,60 & 0,46 \\
\hline & 0,67 & 1,06 & 1,00 & 1,17 & $-0,33$ & $-0,11$ \\
\hline & 0,79 & 1,39 & 1,00 & 2,12 & $-0,21$ & $-0,73$ \\
\hline & 0,67 & 1,12 & 1,60 & 1,51 & $-0,93$ & $-0,39$ \\
\hline & 0,70 & 1,10 & 1,00 & 1,99 & $-0,3$ & $-0,89$ \\
\hline Hipoclorito & 1,53 & 1,02 & 2,00 & 1,54 & $-0,47$ & $-0,52$ \\
\hline & 1,65 & 1,03 & 1,70 & 1,60 & $-1,55$ & $-1,44$ \\
\hline & 1,09 & 0,89 & 1,80 & 0,95 & $-0,71$ & $-0,06$ \\
\hline & 1,25 & 0,78 & 1,50 & 1,10 & $-0,25$ & $-0,32$ \\
\hline & 0,76 & 0,94 & 0,90 & 1,01 & $-0,14$ & $-0,07$ \\
\hline & 1,25 & 1,59 & 1,60 & 1,89 & $-0,35$ & $-0,3$ \\
\hline Média & 0,89 & 1,01 & 1,41 & 1,49 & $-0,52$ & $-0,48$ \\
\hline DP & 0,40 & 0,38 & 0,40 & 0,42 & 0,43 & 0,43 \\
\hline & 1,07 & 1,39 & 1,40 & 2,17 & $-0,33$ & $-0,78$ \\
\hline & 0,90 & 2,30 & 1,69 & 2,85 & $-0,79$ & $-0,55$ \\
\hline & 1,26 & 0,88 & 1,35 & 1,96 & $-0,09$ & $-1,08$ \\
\hline & 0,75 & 1,68 & 1,42 & 1,93 & $-0,67$ & $-0,25$ \\
\hline & 1,50 & 1,00 & 1,93 & 1,42 & $-0,43$ & $-0,42$ \\
\hline Mamona & 1,95 & 1,93 & 2,70 & 2,07 & $-0,75$ & $-0,14$ \\
\hline & 1,56 & 2,33 & 1,88 & 2,85 & $-0,32$ & $-0,52$ \\
\hline & 0,64 & 2,00 & 1,59 & 2,04 & $-0,95$ & $-0,04$ \\
\hline & 1,58 & 1,27 & 1,18 & 1,63 & 0,4 & $-0,36$ \\
\hline & 0,54 & 0,94 & 1,21 & 1,28 & $\begin{array}{c}0,4 \\
-0,67 \\
\end{array}$ & $\begin{array}{l}-0,50 \\
-0,34\end{array}$ \\
\hline Média & 1,18 & 1,57 & 1,64 & 2,02 & $-0,46$ & $-0,45$ \\
\hline DP & 0,47 & 0,55 & 0,45 & 0,52 & 0,40 & 0,31 \\
\hline
\end{tabular}

A análise de variância (Tabela 59) da tabela acima indicou diferença estatística para a interação entre os fatores. 
Tabela 59 - Teste Anova para a rugosidade dos reembasadores resilientes após 15 dias de imersão.

\begin{tabular}{lclccr}
\hline Fonte de Variação & Soma de Quadr. & G.L. & Quadr.Médios & ( F ) & Prob.(H0) \\
\hline Material (M) & 0.6222 & 1 & 0.6222 & 3.81 & $5.316 \%$ \\
Solução (S) & 0.0723 & 2 & 0.361 & 0.22 & $19.540 \%$ \\
M x S & 1.3091 & 2 & 0.6546 & 4.01 & $2.321 \%$ \\
Resíduo & 8.8205 & 54 & 0.1633 & & \\
Variação total & 10.8241 & 59 & & & \\
\hline
\end{tabular}

Entre os materiais, o Elite Soft sofreu maior variação da rugosidade que o Mucopren soft somente no grupo da água. Entre as soluções, para cada grupo de material, não houve diferença estatística (Tabela 60).

Tabela 60 - Comparação das médias da rugosidade superficial $(\mu \mathrm{m})$ dos reembasadores resilientes após 183 dias de imersão.

\begin{tabular}{|c|c|c|c|}
\hline Solução & Elite soft & Mucopren soft & Tukey \\
\hline Água & $-0,69(0,60)^{A a}$ & $-0,07(0,46)^{B a}$ & \\
\hline Hipoclorito & $-0,52(0,43)^{A a}$ & $-0,48(0,43)^{A a}$ & 0,53 \\
\hline Mamona & $-0,46(0,40)^{A a}$ & $-0,45(0,31)^{A a}$ & \\
\hline
\end{tabular}

Na tabela 61 estão apresentados os valores da média, desvio-padrão (DP) e variação $\left(\Delta \mathrm{T}^{183}\right)$ da rugosidade dos corpos-de-prova de reembasadores após o acabamento (T0) e após 183 dias (T183) de imersão nas soluções. 
Tabela 61 - Médias, desvio-padrão (DP) e variação $\left(\Delta \mathrm{T}^{183}\right)$ da rugosidade superficial $(\mu \mathrm{m})$ dos corpos-de-prova de reembasadores resilientes após 183 dias (T183) de imersão.

\begin{tabular}{|c|c|c|c|c|c|c|}
\hline Tempo e variação & \multicolumn{2}{|r|}{ T0 } & \multicolumn{2}{|c|}{ T183 } & $\left(\Delta \mathrm{T}^{183}\right)$ & $\left(\Delta \mathrm{T}^{183}\right)$ \\
\hline Solução Material & $\begin{array}{l}\text { Elite } \\
\text { Soft }\end{array}$ & $\begin{array}{l}\text { Mucopren } \\
\text { Soft }\end{array}$ & $\begin{array}{l}\text { Elite } \\
\text { Soft }\end{array}$ & $\begin{array}{l}\text { Mucopren } \\
\text { Soft }\end{array}$ & $\begin{array}{l}\text { Elite } \\
\text { Soft }\end{array}$ & $\begin{array}{l}\text { Mucopren } \\
\text { Soft }\end{array}$ \\
\hline \multirow{10}{*}{ Água } & 1,99 & 1,93 & 0,65 & 0,95 & 1,34 & 0,98 \\
\hline & 1,99 & 1,06 & 1,80 & 1,17 & 0,19 & $-0,11$ \\
\hline & 0,76 & 1,53 & 0,87 & 0,69 & $-0,11$ & 0,84 \\
\hline & 0,83 & 1,58 & 1,10 & 1,00 & $-0,27$ & 0,58 \\
\hline & 1,66 & 1,52 & 1,20 & 1,10 & 0,46 & 0,42 \\
\hline & 1,86 & 1,11 & 1,00 & 1,11 & 0,86 & 0 \\
\hline & 2,19 & 2,34 & 0,74 & 2,10 & 1,45 & 0,24 \\
\hline & 1,69 & 1,99 & 0,86 & 0,99 & 0,83 & 1 \\
\hline & 1,66 & 0,96 & 0,75 & 0,74 & 0,91 & 0,22 \\
\hline & 2,10 & 0,93 & 0,55 & 1,07 & 1,55 & $-0,14$ \\
\hline Média & 1,67 & 1,50 & 0,95 & 1,09 & 0,72 & 0,40 \\
\hline DP & 0,50 & 0,48 & 0,36 & 0,39 & 0,64 & 0,43 \\
\hline \multirow{10}{*}{ Hipoclorito } & 0,67 & 1,06 & 0,61 & 1,10 & 0,06 & $-0,04$ \\
\hline & 0,79 & 1,39 & 0,73 & 1,46 & 0,06 & $-0,07$ \\
\hline & 0,67 & 1,12 & 0,77 & 1,40 & $-0,1$ & $-0,28$ \\
\hline & 0,70 & 1,10 & 0,57 & 1,40 & 0,13 & $-0,3$ \\
\hline & 1,53 & 1,02 & 1,09 & 1,50 & 0,44 & $-0,48$ \\
\hline & 1,65 & 1,03 & 1,50 & 1,40 & $-1,35$ & $-1,24$ \\
\hline & 1,09 & 0,89 & 0,74 & 1,10 & 0,35 & $-0,21$ \\
\hline & 1,25 & 0,78 & 0,86 & 1,17 & 0,39 & $-0,39$ \\
\hline & 0,76 & 0,94 & 0,75 & 1,26 & 0,01 & $-0,32$ \\
\hline & 1,25 & 1,59 & 0,55 & 1,70 & 0,7 & $-0,11$ \\
\hline Média & 0,89 & 1,01 & 0,82 & 1,35 & 0,22 & $-0,26$ \\
\hline DP & 0,40 & 0,38 & 0,29 & 0,19 & 0,24 & 0,15 \\
\hline \multirow{10}{*}{ Mamona } & 1,07 & 1,39 & 0,73 & 2,14 & 0,34 & $-0,75$ \\
\hline & 0,90 & 2,30 & 0,48 & 2,09 & 0,42 & 0,21 \\
\hline & 1,26 & 0,88 & 0,72 & 0,93 & 0,54 & $-0,05$ \\
\hline & 0,75 & 1,68 & 1,22 & 1,06 & $-0,47$ & 0,62 \\
\hline & 1,50 & 1,00 & 1,54 & 0,70 & $-0,04$ & 0,3 \\
\hline & 1,95 & 1,93 & 2,50 & 2,04 & $-0,55$ & $-0,11$ \\
\hline & 1,56 & 2,33 & 0,91 & 1,98 & 0,65 & 0,35 \\
\hline & 0,64 & 2,00 & 1,50 & 1,61 & $-0,86$ & 0,39 \\
\hline & 1,58 & 1,27 & 1,17 & 1,62 & 0,41 & $-0,35$ \\
\hline & 0,54 & 0,94 & 1,18 & 0,99 & $-0,64$ & $-0,05$ \\
\hline Média & 1,18 & 1,57 & 1,20 & 1,52 & $-0,02$ & 0,06 \\
\hline DP & 0,47 & 0,55 & 0,57 & 0,55 & 0,56 & 0,40 \\
\hline
\end{tabular}

Após a análise dos dados da tabela 61, o teste Anova indicou diferença significante entre os materiais e as soluções. 
Tabela 62 - Teste Anova para a variação da rugosidade $\left(\Delta \mathrm{T}^{183}\right)$ dos reembasadores resilientes após 183 dias de imersão.

\begin{tabular}{lclclr}
\hline Fonte de Variação & Soma de Quadr. & G.L. & Quadr.Médios & ( F ) & Prob.(H0) \\
\hline Material (M) & 0.8592 & 1 & 0.8592 & 4.45 & $3.718 \%$ \\
Solução (S) & 4.2324 & 2 & 2.1162 & 10.97 & $0.024 \%$ \\
M x S & 0.8082 & 2 & 0.4041 & 2.09 & $13.112 \%$ \\
Resíduo & 10.4198 & 54 & 0.1930 & & \\
Variação total & 16.3197 & 59 & & & \\
\hline
\end{tabular}

A comparação das médias indicou que o Elite Soft $(\mu=0,30 \pm 0,48)$ apresentou maior variação na rugosidade superficial após imersão nas soluções por 183 dias se comparado ao Mucopren Soft $(\mu=0,07 \pm 0,32)$.

Para o fator solução, o hipoclorito $(\mu=-0,02 \pm 0,19)$ e a mamona $(\mu=0,02 \pm 0,48)$ tiveram comportamentos semelhantes e diferentes da água $(\mu=0,56 \pm 0,53)$, sendo que o hipoclorito causou aumento da rugosidade. A maior variação da rugosidade ocorreu no grupo da água. 


\subsection{Alteração de cor}

Na tabela 63 estão apresentados os valores da média, desvio-padrão (DP) e variação $\left(\Delta \mathrm{T}^{7}\right)$ da alteração de cor dos corpos-de-prova de reembasadores após o acabamento (T0) e após 7 dias (T7) de imersão nas soluções.

Tabela 63 - Médias, desvio-padrão (DP) e variação de cor $\left(\Delta \mathrm{T}^{7}\right)$ dos corpos-de-prova de reembasadores resilientes após 7 dias (T7) de imersão.

\begin{tabular}{|c|c|c|}
\hline \multirow{2}{*}{ Solução } & \multicolumn{2}{|c|}{$\left(\Delta T^{7}\right)$} \\
\hline & Elite Soft & Mucopren Soft \\
\hline \multirow{10}{*}{ Água } & 1,89 & 1,03 \\
\hline & 1,70 & 1,53 \\
\hline & 1,40 & 1,28 \\
\hline & 1,60 & 1,42 \\
\hline & 1,24 & 1,78 \\
\hline & 1,33 & 1,21 \\
\hline & 1,82 & 1,63 \\
\hline & 0,96 & 1,16 \\
\hline & 1,48 & 1,21 \\
\hline & 1,27 & 1,25 \\
\hline Média & 1,47 & 1,35 \\
\hline DP & 0,29 & 0,23 \\
\hline \multirow{10}{*}{ Hipoclorito } & 8,02 & 1,97 \\
\hline & 8,73 & 1,80 \\
\hline & 8,93 & 2,42 \\
\hline & 9,20 & 2,01 \\
\hline & 8,23 & 1,57 \\
\hline & 7,45 & 2,07 \\
\hline & 8,83 & 1,46 \\
\hline & 9,06 & 1,48 \\
\hline & 9,04 & 1,66 \\
\hline & 8,33 & 1,82 \\
\hline Média & 8,58 & 1,83 \\
\hline DP & 0,56 & 0,30 \\
\hline \multirow{10}{*}{ Mamona } & 7,27 & 3,03 \\
\hline & 6,48 & 4,01 \\
\hline & 7,54 & 2,63 \\
\hline & 6,61 & 2,19 \\
\hline & 9,04 & 2,91 \\
\hline & 8,32 & 3,43 \\
\hline & 8,26 & 3,87 \\
\hline & 7,76 & 2,71 \\
\hline & 8,15 & 2,50 \\
\hline & 6,90 & 2,02 \\
\hline Média & 7,63 & 2,93 \\
\hline DP & 0,83 & 0,67 \\
\hline
\end{tabular}


A análise de variância (Tabela 64) indicou diferença estatística para os dois fatores envolvidos, bem como para a interação entre eles (material/solução).

Tabela 64 - Teste Anova para a variação $\left(\Delta \mathrm{T}^{7}\right)$ de cor dos reembasadores resilientes após 7 dias de imersão.

\begin{tabular}{lclccc}
\hline Fonte de Variação & Soma de Quadr. & G.L. & Quadr.Médios & ( F ) & Prob.(H0) \\
\hline Material (M) & 223.4165 & 1 & 223.4165 & 801.38 & $0.000 \%$ \\
Solução (S) & 195.9779 & 2 & 97.9889 & 351.48 & $0.000 \%$ \\
M x S & 115.4630 & 2 & 57.7315 & 207.08 & $0.000 \%$ \\
Resíduo & 15.0546 & 54 & 0.2788 & & \\
Variação total & 549.9120 & 59 & & & \\
\hline
\end{tabular}

De modo geral, o Elite soft $(\mu=5,89 \pm 0,56)$ apresentou maior variação de cor que o Mucopren soft $(\mu=2,03 \pm 0,40)$ após imersão por 7 dias. Entre as soluções, a menor variação de cor ocorreu no grupo da água $(\mu=1,41 \pm 0,26)$. Entre as soluções de hipoclorito $(\mu=5,20 \pm 0,43)$ e mamona $(\mu=5,28 \pm 0,75)$ não houve diferença estatística.

A comparação das médias para a interação entre os fatores está apresentada na tabela 65.

Tabela 65 - Comparação das médias $(\mathrm{DP})$ da variação $\left(\Delta \mathrm{T}^{7}\right)$ de cor dos reembasadores resilientes pós 7 dias de imersão.

\begin{tabular}{|c|c|c|c|}
\hline Solução & Elite Soft & Mucopren Soft & Tukey \\
\hline Água & $1,47(0,29)^{A a}$ & $1,35(0,23)^{A a}$ & \\
\hline Hipoclorito & $8,58(0,56)^{A b}$ & $1,83(0,30)^{B a}$ & 0,83 \\
\hline Mamona & $7,63(0,83)^{A c}$ & $2,93(0,67)^{B b}$ & \\
\hline
\end{tabular}

Letras maiúsculas: comparação entre colunas; Letras minúsculas: comparação entre linhas.

Letras diferentes indicam diferença estatística.

Avaliando os materiais, houve diferença entre o Elite Soft e o Mucopren Soft após imersão em hipoclorito e mamona, sendo que o Elite Soft foi o material que sofreu a maior variação de cor.

Dentre as soluções, todas tiveram comportamentos diferentes no grupo do Elite Soft. O hipoclorito foi a solução que mais alterou a cor deste material. A água e o hipoclorito tiveram comportamentos semelhantes na alteração de cor dos corpos-de-prova de Mucopren soft, sendo que a mamona foi a solução responsável pela maior variação de cor.

$\mathrm{Na}$ tabela 65 estão apresentados os valores da média, desvio-padrão (DP) e variação $\left(\Delta \mathrm{T}^{15}\right)$ da alteração de cor dos corpos-de-prova de reembasadores após o acabamento (T0) e após 15 dias (T15) de imersão nas soluções. 
Tabela 65 - Médias, desvio-padrão (DP) e variação $\left(\Delta \mathrm{T}^{15}\right)$ de cor dos corpos-de-prova de reembasadores resilientes após 15 dias (T15) de imersão.

\begin{tabular}{|c|c|c|}
\hline \multirow{2}{*}{ Solução } & \multicolumn{2}{|c|}{$\left(\Delta \mathrm{T}^{15}\right)$} \\
\hline & Elite Soft & Mucopren Soft \\
\hline \multirow{10}{*}{ Água } & 3,45 & 2,03 \\
\hline & 5,70 & 1,63 \\
\hline & 2,40 & 2,48 \\
\hline & 2,85 & 2,42 \\
\hline & 2,94 & 3,16 \\
\hline & 4,33 & 3,04 \\
\hline & 1,29 & 3,60 \\
\hline & 0,86 & 3,16 \\
\hline & 2,48 & 1,70 \\
\hline & 1,37 & 2,69 \\
\hline Média & 2,80 & 2,60 \\
\hline $\mathrm{DP}$ & 1,50 & 0,70 \\
\hline \multirow{10}{*}{ Hipoclorito } & 18,33 & 5,95 \\
\hline & 16,49 & 5,82 \\
\hline & 18,93 & 5,42 \\
\hline & 15,49 & 5,02 \\
\hline & 23,53 & 3,46 \\
\hline & 20,43 & 6,17 \\
\hline & 16,97 & 5,18 \\
\hline & 18,68 & 4,53 \\
\hline & 16,31 & 2,66 \\
\hline & 17,32 & 7,52 \\
\hline Média & 18,25 & 5,17 \\
\hline DP & 2,40 & 1,40 \\
\hline \multirow{10}{*}{ Mamona } & 3,17 & 4,28 \\
\hline & 4,48 & 4,81 \\
\hline & 4,00 & 2,73 \\
\hline & 4,81 & 3,63 \\
\hline & 3,46 & 2,81 \\
\hline & 4,10 & 3,76 \\
\hline & 3,26 & 3,37 \\
\hline & 3,65 & 2,41 \\
\hline & 3,13 & 1,50 \\
\hline & 3,45 & 2,97 \\
\hline Média & 3,75 & 3,23 \\
\hline $\mathrm{DP}$ & 0,60 & 1,0 \\
\hline
\end{tabular}

Na tabela 66 encontra-se o resultados da análise de variância dos dados da tabela 65 . 
Tabela 66 - Teste Anova para a variação $\left(\Delta \mathrm{T}^{15}\right)$ de cor dos reembasadores resilientes após 15 dias de imersão.

\begin{tabular}{lclccc}
\hline Fonte de Variação & Soma de Quadr. & G.L. & Quadr.Médios & ( F ) & Prob.(H0) \\
\hline Material (M) & 314.8746 & 1 & 314.8746 & 166.86 & $0.000 \%$ \\
Solução (S) & 995.3331 & 2 & 497.6666 & 263.72 & $0.000 \%$ \\
M x S & 537.5127 & 2 & 268.7563 & 142.42 & $0.000 \%$ \\
Resíduo & 101.9026 & 54 & 1.8871 & & \\
Variação total & 1949.6230 & 59 & & & \\
\hline
\end{tabular}

Os corpos-de-prova de Elite Soft $(\mu=8,27 \pm 1,50)$ apresentaram maior variação de cor se comparado com os de Mucopren Soft $(\mu=3,70 \pm 1,03)$. O hipoclorito $(\mu=11,70 \pm 1,90)$ foi a solução que provocou a maior variação de cor dos corpos-de-prova, independente do material. Não houve diferença estatística entre a água $(\mu=2,70 \pm 1,10)$ e a solução de mamona $(\mu=3,50 \pm 0,80)$.

Analisando a interação, houve diferença entre os materiais após imersão em hipoclorito, sendo que o Elite Soft foi o que mais sofreu alteração de cor. Entre as soluções, o hipoclorito foi diferente das demais no grupo do Elite Soft, enquanto no grupo do Mucopren Soft, houve igualdade estatística entre a mamona e o hipoclorito e entre a mamona e água, com o hipoclorito causando a maior variação de cor (Tabela 67).

Tabela 67 - Comparação das médias (DP) da alteração de cor dos reembasadores resilientes após imersão por 15 dias.

\begin{tabular}{|c|c|c|c|}
\hline Solução & Elite soft & Mucopren soft & Tukey \\
\hline Água & $2,80(1,50)^{A a}$ & $2,60(0,70)^{A a}$ & \multirow{3}{*}{2,18} \\
\hline Hipoclorito & $18,25(2,40)^{A b}$ & $5,17(1,40)^{B b}$ & \\
\hline Mamona & $3,75(0,60)^{A a}$ & $3,23(1,0) A a b$ & \\
\hline
\end{tabular}

$\mathrm{Na}$ tabela 68 estão apresentados os valores da média, desvio-padrão (DP) e variação $\left(\Delta \mathrm{T}^{183}\right)$ da alteração de cor dos corpos-de-prova de reembasadores após o acabamento (T0) e após 183 dias (T183) de imersão nas soluções. 
Tabela 68 - Médias, desvio-padrão (DP) e variação $\left(\Delta \mathrm{T}^{183}\right)$ de cor dos corpos-de-prova de reembasadores resilientes após 183 dias (T183) de imersão.

\begin{tabular}{|c|c|c|}
\hline \multirow{2}{*}{ Solução } & \multicolumn{2}{|c|}{$\left(\Delta \mathrm{T}^{183}\right)$} \\
\hline & Elite soft & Mucopren soft \\
\hline \multirow{10}{*}{ Água } & 3,41 & 2,21 \\
\hline & 7,69 & 1,57 \\
\hline & 2,23 & 2,45 \\
\hline & 3,48 & 4,45 \\
\hline & 5,08 & 3,14 \\
\hline & 6,83 & 1,96 \\
\hline & 5,29 & 3,17 \\
\hline & 5,85 & 2,85 \\
\hline & 7,99 & 1,48 \\
\hline & 6,48 & 2,30 \\
\hline Média & 5,43 & 2,56 \\
\hline DP & 1,92 & 0,89 \\
\hline \multirow{10}{*}{ Hipoclorito } & 31,45 & 18,62 \\
\hline & 29,69 & 19,48 \\
\hline & 32,60 & 26,43 \\
\hline & 28,67 & 25,72 \\
\hline & 34,02 & 23,64 \\
\hline & 32,08 & 26,41 \\
\hline & 29,51 & 25,20 \\
\hline & 29,46 & 25,84 \\
\hline & 29,08 & 23,09 \\
\hline & 30,15 & 26,62 \\
\hline Média & 30,67 & 24,11 \\
\hline DP & 1,77 & 2,92 \\
\hline \multirow{10}{*}{ Mamona } & 4,14 & 10,34 \\
\hline & 4,06 & 10,65 \\
\hline & 2,82 & 6,46 \\
\hline & 3,44 & 2,10 \\
\hline & 6,10 & 7,77 \\
\hline & 6,95 & 14,13 \\
\hline & 5,46 & 11,05 \\
\hline & 5,16 & 3,07 \\
\hline & 6,43 & 6,84 \\
\hline & 6,42 & 9,37 \\
\hline Média & 5,10 & 8,18 \\
\hline DP & 1,42 & 3,71 \\
\hline
\end{tabular}

A tabela 69 apresenta a análise de variância para a variação $\left(\Delta \mathrm{T}^{183}\right)$ de cor dos materiais após imersão nas soluções por 183 dias. 
Tabela 69 - Teste Anova para a variação $\left(\Delta \mathrm{T}^{183}\right)$ de cor dos reembasadores resilientes após 183 dias de imersão.

\begin{tabular}{lclclc}
\hline Fonte de Variação & Soma de Quadr. & G.L. & Quadr.Médios & ( F ) & Prob.(H0) \\
\hline Material (M) & 67.4355 & 1 & 64.4355 & 12.7 & $0.110 \%$ \\
Solução (S) & 6565.0278 & 2 & 3282.5139 & 618.08 & $0.000 \%$ \\
M x S & 236.8831 & 2 & 118.4416 & 22.30 & $0.001 \%$ \\
Resíduo & 286.7863 & 54 & 5.3109 & & \\
Variação total & 7156.1328 & 59 & & & \\
\hline
\end{tabular}

Analisando a tabela acima, pôde-se verificar diferença estatística entre os materiais, onde o Elite soft $(\mu=13,73 \pm 1,70)$ sofreu maior alteração de cor (Mucopren: $(\mu=11,61 \pm 2,50)$. Entre as soluções, houve diferença entre todas (Água: $\mu=4,0 \pm 1,40$; Hipoclorito: $\mu=27,40 \pm 2,34$; Mamona: $\mu=6,64 \pm 2,60$ ), sendo que o hipoclorito causou a maior alteração de cor dos corpos-de-prova.

A comparação das médias da interação entre os fatores indicou que para os materiais houve diferença entre o Elite Soft e o Mucopren Soft no grupo do hipoclorito e da mamona, sendo que o hipoclorito causou maior alteração de cor para o Elite Soft. A mamona promoveu maior alteração de cor para o material Mucopren Soft. Analisando as soluções, o hipoclorito foi diferente das demais soluções no grupo do Elite Soft e todas foram diferentes entre si, no grupo do Mucopren Soft (Tabela 70).

Tabela 70 - Comparação das médias (DP) da variação $\left(\Delta \mathrm{T}^{183}\right)$ de cor dos reembasadores resilientes após imersão por 183 dias.

\begin{tabular}{|c|c|c|c|}
\hline Solução & Elite Soft & Mucopren Soft & Tukey \\
\hline Água & $5,43(1,92)^{A a}$ & $2,56(0,89)^{A a}$ & \\
\hline Hipoclorito & $30,67(1,77)^{A b}$ & $24,11(2,92)^{B b}$ & 3,60 \\
\hline Mamona & $5,10(1,42)^{A a}$ & $8,18(3,71)^{B c}$ & \\
\hline
\end{tabular}

Letras maiúsculas: comparação entre colunas; Letras minúsculas: comparação entre linhas. Letras diferentes indicam diferença estatística.

Nas figuras 20 a 25 estão apresentados os materiais Elite soft e Mucopren soft após imersão nas soluções por 7, 15 e 183 dias. 


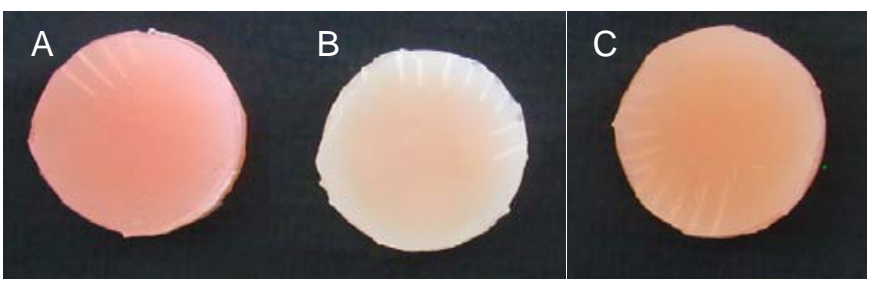

Figura 20 - Corpos-de-prova de Elite soft após imersão por 7 dias em: A: Água; B: Hipoclorito; C: Mamona (Ricinnus Comunnis).

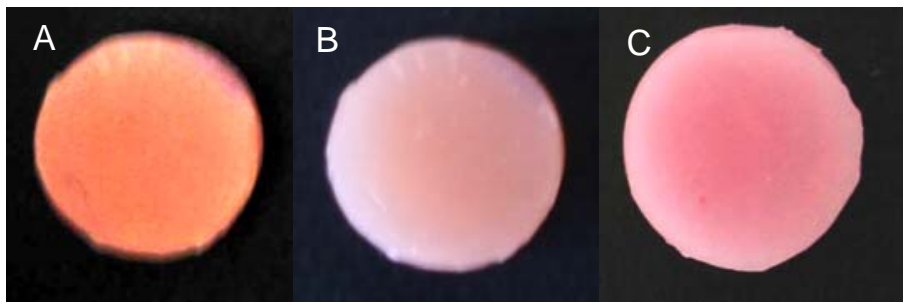

Figura 21 - Corpos-de-prova de Elite soft após imersão por 15 dias em: A: Água; B: Hipoclorito; C: Mamona (Ricinnus Comunnis).

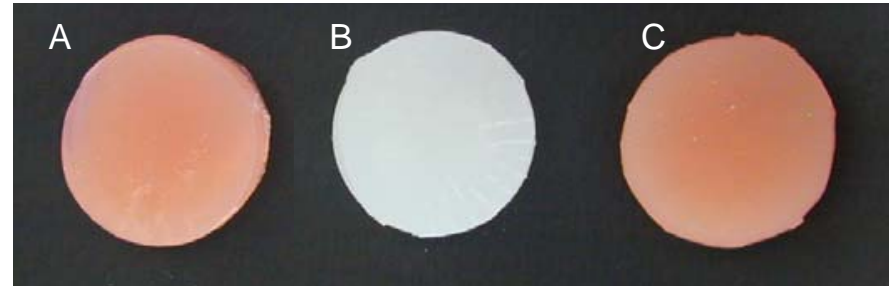

Figura 22 - Corpos-de-prova de Elite soft após imersão por 183 dias em: A: Água; B: Hipoclorito; C: Mamona (Ricinnus Comunnis).

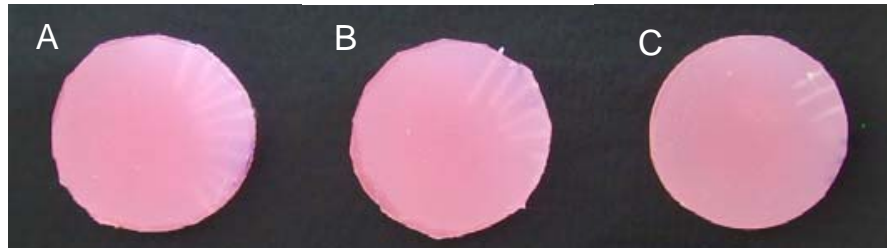

Figura 23 - Corpos-de-prova de Mucopren soft após imersão por 7 dias em: A: Água; B: Hipoclorito; C: Mamona (Ricinnus Comunnis).

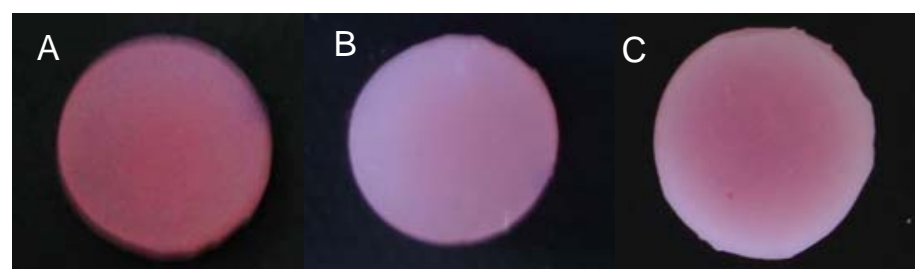

Figura 24 - Corpos-de-prova de Mucopren soft após imersão por 15 dias em: A: Água; B: Hipoclorito; C: Mamona (Ricinnus Comunnis).

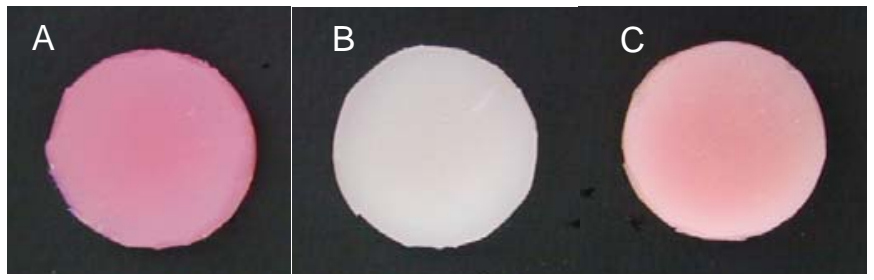

Figura 25 - Corpos-de-prova de Mucopren soft após imersão por 183 dias em: A: Água; B: Hipoclorito; C: Mamona (Ricinnus Comunnis). 


\section{Considerações iniciais}

A higiene de próteses totais tem grande relevância para a saúde do paciente e para a longevidade do aparelho protético. Esta higiene pode ser realizada de forma mecânica, química, ou por meio de uma associação das duas técnicas. Estudos in vitro (DAVENPORT; WILSON; SPENCE, 1986; JIN et al., 2003; MINAGI et al., 1987; MOORE; SMITH; KENNY, 1984; NIKAWA et al., 2003) e in vivo (DILLS et al., 1988; GORNITSKY et al., 2002, KULAK et al., 1997; MOORE; SMITH; KENNY, 1984; RAHAL; MESQUITA, 2001) já foram realizados comprovando a eficácia de agentes químicos na limpeza de próteses. Outros estudos mostraram que essas substâncias, quando utilizadas isoladamente, não são efetivas na remoção do biofilme (BARNABÉ et al., 2004; DILLS et al., 1988; PARANHOS et al., 2007).

Os agentes químicos de limpeza podem apresentar-se como peróxidos ou hipocloritos alcalinos, desinfetantes, ácidos e enzimas. O agente químico considerado ideal deve ser efetivo na remoção de depósitos orgânicos e inorgânicos e possuir propriedades bactericidas e fungicidas. Além disso, deve ser compatível com todos os materiais da prótese e apresentar baixo custo (ABELSON, 1985; JAGGER; HARRISON, 1995). Porém ainda não existe um higienizador que preencha todas estas características, portanto, a busca por um produto ideal motiva o surgimento de novas formulações a serem testadas.

O objetivo da imersão em agentes químicos é obter limpeza e descontaminação. $\mathrm{O}$ hipoclorito de sódio é muito utilizado por ser eficaz na remoção de manchas leves, além de possuir ação bactericida e fungicida (ABELSON, 1985). Apesar de não dissolver o cálculo, inibe sua formação, pois atua sobre a matriz do biofilme (BUDTZ-JORGENSEN, 1979; JAGGER; HARRISON, 1995). Entretanto, o hipoclorito pode causar o branqueamento da resina acrílica, além de possuir odor desagradável e ser contra-indicado para uso em próteses parciais removíveis com componentes metálicos, devido à capacidade de corrosão (SHAY, 2000). A concentração do hipoclorito e o tempo de imersão da prótese nesta solução ainda são discutidos. Neste presente estudo, a concentração de 1\% e imersões durante 20 minutos diário e 8 horas diário (overnight) foram utilizados, uma vez que, segundo Furukawa (1998) imersões por períodos menores não permitem a penetração do higienizador nos poros de reembasadores e resinas, evitando a destruição de microorganismos alojados nestes locais. Além disso, na concentração de 1\%, recomendada por Schaefer (1985), o hipoclorito apresenta-se eficaz em reduzir o número de microrganismos na resina acrílica (PAVARINA et al., 2003a). Maiores concentrações têm efeitos sobre a eliminação de microrganismos, 
porém podem promover efeitos deletérios nas propriedades dos materiais utilizados na confecção das próteses totais (ROBINSON; McCABE; STORER, 1987). Neste trabalho a simulação de imersões por 20 minutos diários simulando 3 anos e por 8 horas diárias durante 1 ano e seis meses foi empregada baseando-se em orientações fornecidas aos pacientes para a higiene diária de suas próteses totais. Outro fator de relevância é que o tempo de troca de uma prótese total está compreendido entre 5 a 7 anos (ZARB; BOLENDER; CARLSSON, 2000), logo a rotina de higiene é utilizada durante tempos prolongados pelo paciente.

Os estudos encontrados na literatura a respeito dos efeitos das soluções químicas para higiene nas propriedades dos materiais utilizados na confecção de próteses totais são avaliações de curto prazo e não fornecem informações substanciosas a respeito do uso prolongado destas soluções (ASAD; WATKINSON; HUGGET, 1992; AZEVEDO et al., 2006; MA; JOHNSON; GORDON, 1997; NEPPELENBROEK et al., 2005; PAVARINA et al., 2003b; POLYSOIS; ZISSIS; YANNIKAKIS, 1995; SHEN; JAVID, COLAIZZI, 1989; ZISSIS et al., 2000).

Neste estudo, foram analisadas as propriedades dos constituintes das próteses totais, a resina acrílica, os dentes artificiais e os reembasadores resilientes frente à imersão em soluções higienizadoras. O efeito dos higienizadores ocorre em função de sua concentração e de seu tempo de ação. A compatibilidade entre os materiais deve ser considerada para eliminar ou minimizar as alterações de propriedades. Sendo assim, a discussão deste trabalho foi dividida em três partes correspondentes à resina acrílica, dentes artificiais e reembasadores resilientes, e os sub-itens correspondem à discussão dos resultados das propriedades analisadas. 


\section{Resina acrílica}

Desde o surgimento, há mais de sessenta anos, a resina acrílica continua sendo o material mais utilizado na confecção de bases de próteses totais devido ao fato de apresentar propriedades físicas e mecânicas adequadas e características de trabalho também favoráveis. Vários tipos de resinas acrílicas e técnicas surgiram ao longo destes anos, com o objetivo de melhorar suas propriedades e aperfeiçoar a confecção de próteses totais.

Para a realização deste estudo, foram utilizadas duas resinas, uma polimerizada por energia de microondas e outra termopolimerizada de modo convencional em banho de água quente ambas de marcas e procedências diferentes. Sabe-se que o método de polimerização das resinas pode ter influência em suas propriedades físicas e mecânicas (LAI et al., 2004).

A polimerização por meio da energia de microondas tem como principais vantagens a diminuição do tempo de polimerização e a limpeza durante o processamento das próteses. Nishii et al. (1968), primeiro autor a descrever o método de polimerização por microondas, observou que as propriedades físicas da resina acrílica polimerizada em microondas e convencional apresentaram-se semelhantes. No entanto, Gettleman, Nathanson e Myerson (1977) atentou para o fato de que, o ciclo de polimerização por microondas, se realizado de forma não cuidadosa, pode promover uma polimerização incompleta e até mesmo a degradação do polímero. De Clerck (1987) também relatou a importância de se ajustar adequadamente a potência e tempo do forno de microondas, pois um sobreaquecimento do monômero pode causar porosidade na resina acrílica e conseqüentes prejuízos às propriedades físicas e mecânicas deste material. Segundo o autor, a polimerização com tempos mais prolongados e potências mais baixas proporciona a reação adequada entre polímero e monômero, diminuindo assim, a liberação de monômero residual que, conseqüentemente, interfere intimamente em propriedades importantes da resina acrílica como dureza e resistência à flexão (ARAB, NEWTON; LLOYD, 1989; HARRISON; HUGGET, 1992).

\subsection{Dureza Knoop}

Segundo Anusavice (2005), o conceito de dureza mais geralmente aceito é o de resistência à penetração. A penetração produzida na superfície de um material, a partir de uma carga aplicada por uma ponta fina ou partícula abrasiva resulta da interação de numerosas propriedades. Dentre as propriedades relacionadas com a dureza de um material, estão a resistência à compressão, limite de proporcionalidade e ductibilidade. Dessa forma, nota-se 
que há uma cadeia interligada de propriedades que podem ser alteradas se cuidados não forem tomados durante a polimerização.

Para reduzir a quantidade de monômero residual e melhorar as propriedades da resina acrílica, o ciclo de polimerização deve ser de no mínimo 50 minutos (DOGAN; EVIK; USANMAZ, 1995). Neste trabalho, os ciclos de polimerização empregados, tanto para a resina convencional como para a de microondas, foram selecionados dentre os mais comumente utilizados em laboratórios de prótese objetivando caracterizar a realidade (Quadro 1). Um cuidado adicional na tentativa de diminuir a influência do monômero residual nas propriedades da resina acrílica foi a imersão dos corpos-de-prova em água por 24 horas.

Simulando imersões diárias de 20 minutos, após 15 dias de imersão, todas as soluções testadas promoveram variação na dureza das resinas avaliadas, levando à diminuição das mensurações obtidas. Vale ressaltar uma exceção onde a solução de mamona causou aumento da dureza na resina acrílica convencional $\left(\Delta \mathrm{T}^{15}=-5,64\right)$. Visualmente, pôde-se perceber que a solução de mamona promoveu a formação de uma película sobre o corpo-de-prova, devido a sua baixa tensão superficial, que pode ter levado à deposição de alguns componentes desta solução e como conseqüência, ter causado o aumento da dureza.

Os resultados encontrados neste estudo estão em acordo com os de Neppelenbroek et al. (2005) que encontraram uma diminuição da dureza de duas resinas acrílicas após imersão em soluções desinfetantes (hipoclorito de sódio 1\%, gluconato de clorexidina a $4 \%$ e perborato de sódio a 3,78\%) em um curto período de tempo (120 dias) e imersões rápidas de 10 minutos.

O monômero residual durante a reação de polimerização permanece na resina acrílica e pode ser lixiviado quando a resina for imersa em soluções de armazenamento, aumentando a dureza das resinas acrílicas, fato semelhante ao ocorrido com a resina termopolimerizada convencional depois de imersa na solução de mamona por 15 dias (VALLITTU, 1996; WEAVER; GOEBEL, 1980).

Após 183 dias de imersão, simulando imersões de 8 horas diárias por 18 meses, todas as soluções, sem exceção, produziram uma redução da dureza tanto na resina acrílica convencional quanto na de microondas. $\mathrm{O}$ contato mais prolongado das soluções de imersão ( 8 horas) com os corpos-de-prova causou efeito contrário àquele obtido com imersões de 20 minutos. Sabe-se que a adição de agentes cross-linked tem como objetivo conferir maior impermeabilidade e resistência, promovendo uma diminuição na absorção de fluidos, evitando variações na dureza. No presente estudo, as resinas empregadas apresentam estes agentes e mesmo assim, sofreram alteração na dureza. Diante disto, duas possibilidades são 
possíveis: os agentes cross-linked não são eficazes na resolução total do problema ou esta alteração ocorreu em função do período de imersão. A água promoveu a maior variação da dureza das resinas se comparada às demais soluções.

As resinas acrílicas são hidrofílicas e absorvem água (BRADEN, 1964; DOGAN; EVIK; USANMAZ, 1995), a qual age como agente plastificador diminuindo a dureza das resinas acrílicas por meio da formação de microtrincas decorrentes do ciclo de absorção e adsorção, além da degradação hidrolítica dos polímeros, com clivagem de ligações ésteres e gradual deterioração de suas infra-estrutura ao longo do tempo (YIU et al., 2004). A maior redução da dureza promovida pela água pode ser explicada pelo fato ser menos iônica que as demais soluções de higiene utilizadas. A água absorvida pode se encontrar em duas formas distintas: "livre", a qual ocupa volumes livres entre as cadeias poliméricas e nanoporos criados durante a polimerização; ou "ligadas": a qual está presa à cadeia polimérica por meio de pontes de hidrogênio causando a formação de cápsulas de hidratação primária e secundária ao redor de terminações hidrofílicas e iônicas da matriz da resina (YIU et al., 2004). Segundo Braden (1964), a absorção e adsorção de água pelas resinas acrílicas são regidas pelo coeficiente de difusão (passagem do líquido do meio mais saturado para o menos), e equilíbrio de concentração (quando a saturação dos dois meios se equilibra, cessando o transporte do liquido).

Quando imersas em soluções higienizadoras, a resina acrílica sofre absorção uma vez que estas soluções são aquosas. Onde ocorre aumento de dureza, pode ter havido alguma alteração na cadeia polimérica da resina. Onde foi observada pouca alteração da dureza, pode ter ocorrido uma saturação do meio, cessando o processo de absorção e adsorção. Entretanto, os resultados deste estudo indicaram variação de dureza para todas as soluções, sendo que o hipoclorito de sódio a $1 \%$ promoveu alterações semelhantes nas duas resinas. Já a solução de mamona comportou-se de forma adversa, ora aumentando a dureza de uma e ora diminuindo a dureza da outra, independente do período de imersão simulado. 


\subsection{Rugosidade superficial}

Este estudo buscou avaliar propriedades importantes para o bom desempenho das próteses totais. Dentre tais propriedades, a rugosidade foi avaliada por tratar-se de um fator diretamente relacionado ao acúmulo de biofilme sobre a superfície da prótese em função. A rugosidade na superfície da resina acrílica para base protética tem sido relacionada ao processo inflamatório que pode ocorrer na mucosa subjacente à base de próteses totais por diversos autores (ALLISON; DOUGLAS, 1973; BOLLEN; LAMBRECHETS; QUIRYEN, 1997; DAVENPORT, 1972; HARRISON; JOHNSON; DOUGLAS, 2004).

A unidade de medida de rugosidade usada é a Ra, que representa a variação aritmética média entre as irregularidades de um trajeto de mensuração, sobre a superfície (RADFORD; CHALLACOMBE; WALTER, 1999). Não há um valor específico para rugosidade da resina acrílica, pois a rugosidade está intimamente ligada ao polimento, porém sabe-se que valores abaixo ou iguais a $20 \mu \mathrm{m}$ dificultam a adesão de microrganismos sobre a superfície (BOLLEN; LAMBRECHETS; QUIRYEN, 1997).

Ao mesmo tempo em que a higienização de próteses totais por produtos químicos é importante para remoção do biofilme, alguns estudos afirmam haver alteração da rugosidade superficial por ação de higienizadores químicos (AZEVEDO et al., 2006; MA; JOHNSON; GORDON, 1997; SHEN; JAVID; COLAIZZI, 1989).

Após 15 dias de imersão, todas as soluções promoveram um aumento, na rugosidade superficial das resinas acrílicas, sendo que a solução de mamona foi a que promoveu o maior aumento. Não houve diferença entre os materiais. Os resultados de Garcia et al. (2004) demonstraram redução na rugosidade após imersão em soluções efervescentes para higiene. Ma, Johnson e Gordon (1997) não encontraram alteração após 7 dias de imersão em hipoclorito a 5,25\%; Azevedo et al. (2006) também não encontraram alterações após imersão em hipoclorito a 1\%. Foi observado que a solução de mamona formou uma película espessa e pegajosa sobre os corpos-de-prova, fato que pode ter causado o aumento nos valores de rugosidade. Além disso, a solução de mamona apresenta capacidade de aumentar a permeabilidade de estruturas dentais (FERREIRA et al., 2002), que se aplicada à resina acrílica, poderia explicar o aumento da rugosidade. Ensaios de microscopia são necessários para confirmação desta ação.

Após 183 dias de imersão, a água $\left(\Delta \mathrm{T}^{183}=0,025\right)$ e a mamona $\left(\Delta \mathrm{T}^{183}=0,017\right)$ promoveram uma redução na rugosidade e apresentaram-se estatisticamente semelhantes entre si, porém esta redução foi muito pequena se comparada com a de 15 dias. Já a solução de 
hipoclorito, causou um pequeno aumento na rugosidade $\left(\Delta^{183}=-0,015\right)$. Foi observado que após a higienização, os corpos-de-prova imersos em hipoclorito perderam um pouco do brilho do polimento. Acredita-se que o hipoclorito possa ter interferido com a camada mais superficial da resina e se difundido para a massa mais interna, expondo irregularidades desta região. O efeito desta solução na rugosidade pode estar associado ao longo período de contato do corpo-de-prova com a solução de imersão, diferente do que aconteceu após 15 dias.

Embora tenham ocorrido alterações após imersão nas soluções higienizadoras, o valor de Ra ainda se encontra muito próximo do recomendado, e com exceção do hipoclorito, a solução de mamona promoveu uma redução na rugosidade com a simulação de imersões de 8 horas por 18 meses, o que favorece menor adesão microbiana.

Considerando que a rugosidade da superfície da resina acrílica favorece o acúmulo de biofilme, um valor máximo aceitável de rugosidade deveria ser considerado ao se selecionar o material, a técnica de processamento, tipo de polimento, solução de higiene à qual será submetida a prótese total, bem como o tempo de imersão a ser preconizado. Sendo assim, segundo os resultados deste estudo para esta variável, as duas resinas avaliadas (convencional e de microondas) associadas à imersões overnight de mamona seria o mais indicado.

\subsection{Alteração de cor}

A estabilidade de cor é uma das propriedades químicas mais importantes para todos os materiais dentários (POLYSOIS et al., 1997), uma vez que serve como indicador da idade ou das condições de manutenção dos materiais (JIN et al., 2003; MAKILA, 1979; POLYSOIS et al., 1997). Segundo Villar et al. (2003), os pacientes apresentam-se mais satisfeitos quando o material resiliente se mantém estável e com a cor indistinguível do material de base da prótese, e a motivação para manter a higiene da dentadura depende da facilidade da limpeza e da ausência de manchas. A manutenção da estabilidade de cor do material resiliente à base de silicone, geralmente, não é problema, embora este tipo de material pode sofrer a incorporação de corantes alimentares, bebidas, ou produtos derivados do tabaco (SARAÇ et al., 2007).

As leituras de cor foram realizadas utilizando um espectrocolorímetro, sendo as medidas de cor obtidas no sistema de cor CIELab, recomendado pela Commission Iternacionale de l'Eclairage (CIE), similarmente a outros estudos (JIN et al, 2003; LIBERMAN et al., 1995; MALHEIROS-SEGUNDO et al., 2008; POLYSOIS et al., 1997).

Após 15 dias de imersão, não houve diferença na alteração de cor entre as resinas e nem entre as soluções. Após 183 dias de imersão, houve diferenças entre as resinas sendo que 
a maior variação de cor foi encontrada na resina convencional $\left(\Delta \mathrm{T}^{183}=2,00\right)$ quando imersa em solução de mamona $\left(\Delta \mathrm{T}^{183}=2,06\right)$. A resina termopolimerizada de modo convencional utilizada neste estudo pode ter apresentado menor quantidade de agentes cross-linked no monômero, o que pode ter causado maior alteração de cor, uma vez que estes agentes são resistentes e imunes a um grande número de solventes. Além disso, a polimerização por meio de água quente (convencional) tem como efeito adicional uma expansão térmica que pode envolver a absorção de maior quantidade de água. Este fato pode levar a formação de zonas com diferentes propriedades ópticas que promovem alteração na cor (ARAB; NEWTON; LLOYD, 1989; DEVLIN; KAUSHIK, 2005).

Com relação às soluções, o resultado esperado era que a maior variação de cor ocorresse com o hipoclorito, uma vez que a literatura ressalta seu poder de clareamento (ABELSON, 1985; ABERE, 1979). A água pode causar efeitos deletérios nas propriedades mecânicas da resina acrílica, como a alteração de cor. Segundo Devlin e Kaushik (2005), suas moléculas interferem com a cadeia polimérica do polímero e atuam como plastificantes. Os efeitos da água nas resinas acrílicas são interessantes do ponto de vista clínico, uma vez que a recomendação da imersão do aparelho protético em água durante a noite é freqüente. A solução de mamona utilizada foi muitas vezes diluída em água ( $1 \mathrm{ml}$ da solução pura/100ml de água), podendo explicar tais resultados.

A correta polimerização da resina acrílica é um fator que deve ser obedecido, uma vez que a utilização errônea de baixas temperaturas ou tempos reduzidos resultam em altos níveis de monômero residual (AUSTIN; BASKER, 1982) que podem conduzir ao branqueamento por reagirem com solventes externos (ROBINSON; McCABE; STORER, 1985; ÜNLÜ, ALTAY; SAHMALI, 1996). No entanto, Arab, Newton e Lloyd (1989) concluíram que o monômero residual não é o principal causador de branqueamento da resina acrílica. Segundo Robinson, McCabe e Storer (1985) o monômero residual pode exacerbar os efeitos de solvatização (associação de moléculas de soluto e solvente formando um solvato) que são acelerados pelo aumento da temperatura. Segundo os autores, a causa mais provável de branqueamento é a combinação de alta temperatura, exposição a higienizadores de próteses, além da manipulação incorreta da resina acrílica, ou seja, inclusão de óleos ou umidade das mãos do operador, causando deterioração da massa. A temperatura da água usada pelos pacientes nos procedimentos de limpeza de próteses totais é um fator crítico para o branqueamento da resina acrílica quando da utilização de altas temperaturas (ARAB; NEWTON E LLOYD, 1988; CRAWFORD et al., 1986; ROBINSON; MCCABE; STORER, 1987). As resinas devem ser corretamente polimerizadas e os higienizadores usados na 
concentração e temperatura indicadas pelo fabricante para evitar alterações na cor (ARAB; NEWTON E LLOYD, 1988; SATO, 2005).

Em trabalho de Ma, Johnson e Gordon (1997), a imersão em hipoclorito de sódio por 7 dias levou ao clareamento das resinas, porém os autores empregaram hipoclorito a 5,25\%. McNeme, Von Gotem e Woolsey (1991) e Polysois et al. (1997) não encontraram alterações de cor em resinas acrílicas após o uso de hipoclorito de sódio em diversas concentrações (1\%, $5,25 \%, 0,525 \%$ ), porém os tempos de imersão empregados foram menores, ou seja, 72 horas e 7 dias. Neste estudo, simulando 3 anos de imersões diárias de 20 minutos, os resultados obtidos indicaram que a resina acrílica de microondas associada ao hipoclorito de sódio a $1 \%$ apresentou resultados mais satisfatórios.

\subsection{Resistência à flexão}

Fraturas em bases de resina acrílica representam um problema nas reabilitações com próteses totais. A falta de resistência e dureza são as causas de $10 \%$ das fraturas em próteses totais após 3 anos de uso (VAN NOORT, 2004). Alguns tipos de fraturas estão relacionados à fadiga flexural, a qual pode ocorrer por deficiência de processamento que abrange o método, ciclo de polimerização e quantidade de monômero e polímero. Atualmente encontram-se muitas resinas reforçadas como tentativa de aumentar a resistência à fratura.

A resistência à flexão de um material é uma combinação das forças de compressão, tensão e de cisalhamento. Quando as forças de tensão e compressão aumentam, a força necessária para ocorrer fratura também aumenta (JOHN; GANGADHAR; SHAN, 2001). A resistência à flexão é dependente de fatores como o peso molecular do polímero, a presença de monômero residual e de plastificadores, a temperatura, carga empregada e o conteúdo de água (STAFFORD et al., 1968).

Sabe-se que as fraturas do material podem se originar por meio das formações de trincas e de sua propagação em áreas de alta concentração de estresse (DARBAR; HUGGET; HARRISON, 1994). Neste trabalho, todas as normas da ADA (1975) foram seguidas para o teste de flexão. Porém segundo Sadamori et al. (1990) uma das limitações deste ensaio é que o acabamento e desgaste dos corpos-de-prova podem levar a um aquecimento causando uma conversão de monômero residual, podendo levar a erros de interpretação dos resultados.

Segundo a norma ISO 1567, a resistência flexural para as resinas acrílicas polimerizáveis de forma convencional ou por energia de microondas não deve ser inferior a $65 \mathrm{MPa}$, asserção que está em acordo com os resultados obtidos neste estudo. 
Tem sido demonstrado que a imersão em soluções higienizadoras pode afetar a força e a estrutura das resinas acrílicas (ROBINSON; MCCABE; STORER, 1987). Se este fato realmente ocorre, as incidências de fraturas aumentam tanto dentro quanto fora da boca.

Após 15 dias de imersão, não houve diferença quanto à resistência flexural entre as duas resinas. Este resultado está de acordo com Levin, Sanders e Reitz (1989), Alkihatib, Goodacre e Swartz (1990) e Reitz, Sanders e Levin (1985) que não encontraram diferenças na resistência à flexão de resinas convencional e de microondas. No entanto, os corpos-de-prova não foram imersos em qualquer solução.

A solução de hipoclorito causou a menor resistência à flexão $(87,4 \mathrm{MPa})$ se comparado à água $(99,86 \mathrm{MPa})$ e à mamona $(106,27 \mathrm{MPa})$, as quais apresentaram-se estatisticamente iguais. A solução de hipoclorito pode ter alterado a cadeia polimérica da resina, diminuindo sua resistência. A absorção de líquidos que agem como plastificantes podem eventualmente causar um enfraquecimento das ligações intermoleculares contribuindo para redução da resistência flexural (DEVLIN; KAUSHIK, 2005). Não se pode dizer que houve aumento ou diminuição na resistência à flexão para as resinas, pois não foram obtidos os valores iniciais antes das imersões.

Resultados contrários aos do período de imersões rápidas foram obtidos após 183 dias de imersão. A resina acrílica de microondas apresentou os menores valores de resistência à flexão, tanto após a imersão em hipoclorito (67,55MPa) como em mamona (64,0MPa). De acordo com Smith, Powers e Ladd (1992), a resina de microondas absorve menos energia antes de se fraturar, pois tem peso molecular mais baixo que a convencional devido à rápida polimerização. Esta característica é responsável pela menor resistência à flexão. Outros fatores podem contribuir com estes resultados, tais como, diferenças na composição e ao ciclo de polimerização empregado. A proporção pó/líquido recomendada pelo fabricante é maior para a resina termopolimerizável convencional $(21 \mathrm{~g} / 10 \mathrm{ml})$ do que para a resina de microondas $(21 \mathrm{~g} / 7 \mathrm{ml})$; logo, na resina termopolimerizada de modo convencional pode ter ocorrido maior saturação do polímero com o monômero gerando menor quantidade de monômero residual e melhores propriedades na resistência à flexão.

Estes resultados estão em desacordo com os resultados de Barbosa et al. (2007) que ao compararem as resinas de microondas (Onda Cryl) e convencional (Clássico) encontraram maiores valores para a resistência à flexão para as resinas de microondas.

Uma observação importante a ser ressaltada neste estudo é que, mesmo seguindo as recomendações dos fabricantes e a manipulação ter sido padronizada por um mesmo operador, os corpos-de-prova gerados após a polimerização por microondas apresentaram 
maior quantidade de bolhas visíveis se comparados aos de resina acrílica convencional. Segundo De Clerck (1987) a polimerização por microondas promove uma maior absorção de energia no início da reação e então ocorre um rápido aumento na temperatura da resina, o que poderia levar à formação de porosidades e diminuição dos valores de resistência à flexão. Alkihatib, Goodacre e Swartz (1990) relataram ainda que, possivelmente, quanto maior a espessura do corpo-de-prova, menor seria a resistência à flexão da resina acrílica polimerizada pela energia de microondas devido a maior quantidade de poros encontrados em espessuras acima de $3 \mathrm{~mm}$.

É interessante observar que para o período de imersão de 20 minutos, não houve diferença significante na resistência à flexão das resinas enquanto que, para as imersões de 8 horas, a resina de microondas apresentou-se menos resistente. Se os corpos-de-prova polimerizados em microondas apresentaram maior número de bolhas visíveis que os de resina convencional e o resultado foi inferior para o período de imersão mais prolongado, pode-se pensar que o contato mais prolongado dos espécimes com as soluções de imersão empregadas pode, de alguma forma, ter interferido nos resultados.

Mesmo os higienizadores tendo influenciado na propriedade de resistência flexural da resina acrílica polimerizada em microondas, os valores encontrados ainda estão condizentes com os aceitáveis pela norma ISO 1567, exceto para a solução de mamona. A absorção de soluções aquosas por difusão pela resina acrílica pode comprometer a resistência do material devido a sua função de plastificador. Em seu estudo, Takahashi, Kawaguchi e Chai (1997) demonstraram que a imersão em água por 24 horas e 30 dias diminuiu a resistência a flexão de resinas acrílicas. Isto talvez justifique o fato de a mamona ter promovido um valor de resistência à flexão ligeiramente abaixo do aceitável quando utilizada durante o período de um ano e 6 meses com imersões diárias por 8 horas. 


\section{Dentes artificiais}

Os dentes artificiais utilizados para este estudo foram selecionados obedecendo a uma escala de preços, sendo que os dentes com custo maior e teoricamente de melhor qualidade eram os da marca Trilux, os intermediários da marca Biolux e os mais acessíveis da marca Vipi. Para o entendimento dos resultados é importante que se conheça os componentes destes dentes. Os dentes Trilux possuem tripla prensagem (incisal, dentina e cervical), são formados por resina acrílica de alto peso molecular combinada com o uso de dupla ligação cruzada (DCL) e sistema de rede polimérica e interpenetrada. Os dentes Biolux possuem dupla prensagem (corpo e esmalte), são formados por polímero de alto peso molecular aliado ao uso de DCL, formando ligações entre as redes de polímeros interpenetradas, resultando em um dente formado por uma única molécula polimérica. Os dentes Vipi possuem dupla prensagem (corpo e esmalte) e uma cadeia de polímeros linear e não interpenetrada.

O poli(metil)metacrilato utilizado na fabricação dos dentes protéticos é similar ao usado nas resinas acrílicas para bases de próteses totais, porém a quantidade de agentes crosslinked presentes nos dentes é maior. A presença destes agentes oferece resistência aos solventes e ao desgaste, impedindo impregnações, odores desagradáveis e contribuem para obtenção de próteses dentárias inalteráveis no meio bucal e não irritantes. Além disso, a presença de agentes cross-linked permite um melhor polimento. Todos os dentes testados apresentam cross-linked.

\subsection{Dureza Knoop}

A dureza dos dentes artificiais tem sido pouco estudada (KAWANO et al., 2002; NOGUEIRA, 2002; PAVARINA et al., 2003c). O termo dureza é invariavelmente confundido com o padrão de desgaste dos materiais. Devido a este fato, muitos profissionais da odontologia enaltecem os dentes artificiais que apresentam maior dureza.

Há controvérsias quanto à medida de dureza ideal para ser utilizada em testes com dentes artificiais. Alguns autores utilizaram a dureza Vickers (KAWANO et al., 2002; PAVARINA et al., 2003c), porém o uso deste tipo de dureza é mais indicado para materiais friáveis. Para os materiais poliméricos é recomendado o uso da medida de dureza Knoop, que permite a mensuração em regiões muito pequenas. A indicação da dureza Knoop para os polímeros deve-se ao fato de que a diagonal do losango mensurada para a determinação do valor de dureza (diagonal de maior comprimento) permanece livre de alterações dimensionais, 
ao passo que a recuperação elástica e as alterações dimensionais ocorrem ao longo da diagonal mais curta. Portanto, o valor da dureza Knoop, virtualmente, independe da ductibilidade do material testado devido à ação de rasgamento promovida ao longo da diagonal maior do losango, diferentemente do que ocorre com a impressão quadrangular da dureza Vickers, na qual há deformação elástica de forma similar em ambas as diagonais do quadrado impresso na superfície do material (CRAIG; O'BRIEN; POWERS, 1988; O'BRIEN, 1997).

É possível encontrar na literatura trabalhos que avaliaram a dureza após a imersão de dentes artificiais em água destilada (KAWANO et al., 2002; PAVARINA et al., 2003c; WHITMAN, 1987), bem como em soluções desinfetantes de próteses (PAVARINA et al., 2003c), entretanto estes trabalhos são escassos e tem como limitações não simular adequadamente o ambiente oral e as diferenças de $\mathrm{pH}$.

Após 15 dias de imersão, houve diferença entre os dentes, sendo que a marca Vipi sofreu aumento da dureza $\left(\Delta \mathrm{T}^{15}=-1,84\right)$ enquanto a marca Trilux $\left(\Delta \mathrm{T}^{15}=1,28\right)$ sofreu a maior redução de dureza seguido pelo Biolux. A solução de mamona provocou aumento na dureza $\left(\Delta T^{15}=-3,28\right)$ e o hipoclorito, uma diminuição $\left(\Delta T^{15}=1,92\right)$. O aumento da dureza dos dentes da marca Vipi após a imersão pode ter ocorrido devido ao fato de serem menos resistentes à perda de plastificantes e de possuírem uma cadeia de polímeros linear e não interpenetrada, o que diminui sua resistência. Whitman et al. (1987) não encontraram diferença na dureza de dentes artificiais testados após imersão em água destilada, porém houve diminuição da dureza após imersão em etanol.

Em 1996, Adams afirmou que os dentes artificiais, assim como os naturais (no qual o esmalte possui maior dureza que a dentina) possuem diferenças quanto à dureza de suas faces externa e interna, porém as empresas fabricantes negam este fato. Uma das limitações deste presente estudo é que a rugosidade e dureza foram realizadas após planificação por desgaste da face palatina, portanto, na camada mais interna do dente. Somente a alteração de cor foi realizada na face mais externa e polida.

Após 183 dias, todas as marcas de dentes sofreram uma redução na dureza, sendo que o Trilux sofreu maior redução $\left(\Delta \mathrm{T}^{183}=12,7\right)$, seguido do Biolux $\left(\Delta \mathrm{T}^{183}=8,05\right)$ e do Vipi $\left(\Delta \mathrm{T}^{183}=2,86\right)$. A solução de mamona promoveu a menor redução da dureza $\left(\Delta \mathrm{T}^{183}=6,0\right)$ após este período de imersão. Estes resultados estão de acordo com Pavarina et al. (2003c) que encontraram uma diminuição na dureza dos dentes artificiais após duas imersões em soluções higienizadoras (hipoclorito de sodio a $1 \%$, clorexidina a $4 \%$ e perborato de sodio a $3,78 \%$ ) durante 10 minutos após 120 dias, porém os autores não encontraram diferença entre as 
marcas testadas e as soluções. O mesmo ocorreu no trabalho de Nogueira (2002), que encontrou diminuição da dureza dos dentes artificiais testados após 6 meses de imersão em água (controle) e nas soluções de clorexidina, hipoclorito de sódio $1 \%$ e solução caseira de hipoclorito de sódio diluído.

É possível observar que a mamona promoveu resultados contrários àqueles obtidos após 15 dias. Talvez este fato possa ser explicado pela saturação do meio, a partir de um determinado momento, não havendo absorção de líquidos. As absorções de água e de higienizadores aquosos promovem redução na dureza devido ao fato de agirem como plastificantes. As pequenas moléculas de água difundem-se para dentro da massa do polímero e causam o relaxamento das cadeias poliméricas e, conseqüentemente, diminuem a dureza dos dentes artificiais (CAMPANHA et al., 2005; VON FRAUNHOFER; SUCHATLAMPONG, 1975). Os dentes formados por agentes cross-linked e rede poliméricas interpenetradas deveriam promover, em teoria, uma diminuição na difusão de fluidos para o polímero. Entretanto, devido a algum fato inerente da própria prensagem do material ou da sua composição, os dentes Trilux apresentaram a maior redução da dureza após 183 dias.

\subsection{Rugosidade superficial}

Após 15 dias de imersão, não houve diferença quanto às marcas dos dentes. A mamona promoveu aumento na rugosidade $\left(\Delta \mathrm{T}^{15}=-0,015\right)$, enquanto a água $\left(\Delta \mathrm{T}^{15}=0,029\right)$ e o hipoclorito $\left(\Delta \mathrm{T}^{15}=0,025\right)$ causaram redução nesta propriedade. Estas diferenças podem ser causadas por fatores como a capacidade de promover aumento da permeabilidade (PÉCORA et al., 2000; PEREIRA et al., 2002; SAMPAIO, 1999) da solução de mamona, que pode ter umectado a superfície dos dentes e infiltrado pelas camadas causando alterações no polímero e originando aumento da rugosidade.

Após 183 dias de imersão, somente o dente da marca Biolux apresentou um aumento na rugosidade $\left(\Delta T^{183}=-0,05\right)$, independente da solução. Após imersão nas soluções, os dentes Biolux foram menos resistentes à ação dos solventes, o que pode ter permitido a perda de componentes como os agentes plastificantes e a exposição das camadas polidas com lixas de menor granulação, originando bolhas na massa polimérica, as quais são representativas de um aumento na rugosidade. Não foram encontrados artigos na literatura que analisassem a rugosidade superficial de dentes artificiais em soluções de higiene. 
Para os dentes artificiais, pôde-se perceber que em ambos os períodos avaliados, houve alterações na rugosidade. No entanto, os resultados indicam que a melhor associação entre dentes e higienizador seria Trilux ou Vipi e solução de hipoclorito.

\subsection{Alteração de cor}

A falha ou sucesso estético depende da estabilidade de cor dos materiais protéticos, em especial dos dentes artificiais. A estabilidade de cor é a capacidade do material em manter sua cor através do tempo de uso e em um ambiente específico. Os dentes de resina acrílica são mais susceptíveis a abrasão e à incorporação de pigmentos do que os dentes de porcelana. Robinson, McCabe e Storer (1985) afirmaram que os dentes artificiais posteriores são mais freqüentemente afetados que os anteriores, mas não citaram a causa.

Para minimizar a alteração de cor, surgiram os dentes de acrílico reforçados e melhorados. Existem alguns problemas metodológicos para a pesquisa de alteração de cor em dentes artificiais uma vez que o ambiente oral é dificilmente reprodutível e o espectrocolorímetro pode projetar a luz em varias direções porque a face vestibular não é plana. Devido a este fato, no presente estudo, a mensuração de cor foi realizada utilizando-se um dispositivo confeccionado para encaixe dos dentes para diminuir a reflexão da luz em muitas direções.

Sabe-se que bebidas e alimentos cromogênicos podem alterar a cor dos dentes artificiais (LAMIA MUTLU-SAGESEN et al., 2001). A descoloração clínica destes elementos pode ocorrer devido a fatores intrínsecos e extrínsecos (IAZETTI et al., 2000). Os fatores intrínsecos estão relacionados com a estabilidade química do material e a oxidação das matrizes do polímero. A cor intrínseca pode ser afetada pela termociclagem, efeitos da luz solar e da água, irradiação ultravioleta, temperatura e mudanças na umidade (INOKOSHI et al.,1996).

Os fatores extrínsecos que produzem descoloração incluem o manchamento por absorção e adsorção de corantes e manchas. Soluções corantes, café, chá, clorexidina, refrigerantes e nicotina são conhecidos como causadores de manchas em resinas, inclusive em dentes artificiais compostos por resina acrílica (COOLEY et al., 1987; IAZETTI et al., 2000)

A leitura da cor varia dependendo do instrumento utilizado e o tipo de superfície do material a ser analisado (LAMIA MUTLU-SAGESEN, 2001). Foi demonstrado que o espectrocolorímetro que se baseia no tristímulo $L^{*} A^{*} B^{*}$ é o método mais adequado para determinar a cor de dentes artificiais (SEGHI; JOHNSTON; O’BRIEN, 1989). 
Os trabalhos envolvendo dentes artificiais variam muito em relação ao tipo e geometria dos dentes, tipo das soluções e dos instrumentos para medição da alteração de cor (LUCE; CAMPBELL, 1988; SEGHI, 1990).

Após a imersão por 15 dias, o dente da marca Biolux apresentou a menor variação de cor $\left(\Delta \mathrm{T}^{15}=0,99\right)$ em relação aos demais dentes. Este resultado concorda com o encontrado por Mello (2007). Não houve diferença estatística entre a água destilada, hipoclorito de sódio e solução de mamona. Após 183 dias de imersão, simulando 1 ano e meio de imersões overnight, não houve diferença estatística entre as soluções e nem entre os materiais, logo, a presença dos agentes cross-linked podem ter evitado alterações por promoverem resistência aos solventes. Segundo Robinson, McCabe e Storer (1985), as diferentes camadas dos dentes artificiais de resina acrílica são afetados em diferentes graus de intensidade pelas soluções e ocorre uma alteração da matriz intersticial.

A maior descoloração em uma substância do que em outra é devido à absorção e adsorção de corantes e devido às diferentes pigmentações presentes para a caracterização dos dentes. Quanto menos polares forem os corantes, mais penetraram na resina, provavelmente porque os corantes são compatíveis com as matrizes poliméricas dos dentes (LAMIA MUTLU-SAGESEN, 2001). O dente Biolux que apresentou a menor alteração de cor após 15 dias provavelmente absorveu menor quantidade de solução.

De acordo com Johnson e Kao (1989), se a variação de cor segundo a NBS for menor que 1, esta variação é considerada muito pequena e entre 1 e 2, a situação é clinicamente aceitável. Goldstein e Schmitt (1993), em suas observações concluíram que quando a variação de cor $(\Delta \mathrm{E})$ exceder 3,7 o material assumirá uma qualidade visual clinicamente detectável. Os valores de $\Delta \mathrm{E}$ apresentados nas tabelas 38 e 39 mostram valores aceitáveis para a alteração de cor dos dentes testados após as imersões.

Cabe salientar que alguns fatores são predisponentes para o manchamento de materiais acrílicos dentre eles: a contaminação dos materiais, porosidades, higiene oral insuficiente, hábitos de dieta, falhas na superfície, e polimento dos materiais (BURROW; MAKINSON, 1991). Faces rugosas retêm mais manchas. O aumento da rugosidade causado por desgaste ou degradação química pode também aumentar a descoloração por fatores extrínsecos (IAZETTI et al., 2000). Os acrílicos cross-linked são mais resistentes e imunes a um grande número de solventes. No entanto, segundo Craig e Ward (1997), quando a resina tem sua dureza alterada pelos solventes, os higienizadores penetram nas camadas dos dentes e causam descoloração. No presente estudo, alterações da dureza foram detectadas, porém a cor apresentou-se altamente estável. 


\section{Reembasadores resilientes}

Atualmente, o uso de reembasadores resilientes macios, está se tornando cada vez mais comum, uma vez que têm como principal função, atuar na absorção e distribuição da força mastigatória às áreas de suporte primário do rebordo alveolar do edentado. Os reembasadores macios promovem conforto aos pacientes que não podem suportar pressão oclusal, como nos casos de rebordo alveolar muito reabsorvido e/ou flácido (WRIGHT, 1976). Outras indicações deste material concentram-se em casos de pacientes que, devido à remoção de tumores orais, apresentam defeitos pós-operatórios que requerem próteses obturadoras e nos casos de próteses transicionais após o estágio I e II da cirurgia para colocação de implantes (RUSSELL, 1976).

Algumas características são de extrema importância para o sucesso no uso de reembasadores resilientes e dentre elas podem ser citadas: facilidade na técnica de processamento, mínima sorção de água e solubilidade, manutenção da resiliência, boa adesão à base da prótese, boa resistência à ruptura, estabilidade dimensional, facilidade de higienização, atoxicidade e ausência de odores (QUDAH; HARRISON, HUGGET, 1990).

Os materiais reembasadores à base de silicone são compostos basicamente de polímeros de dimetilsiloxano que possuem ligações cruzadas que controlam sua maciez. Geralmente, apresentam boas propriedades elásticas (McCABE, 1976) e não é necessária a adição de plastificantes para obter resiliência. Os materiais à base de silicone retornam às suas formas originais quase imediatamente após a remoção da carga devido ao seu grande número de ligações cruzadas (McCABE, 1976). Neste estudo foram selecionados dois materiais reembasadores à base de polivinilsiloxano, sendo classificados como materiais resilientes com maior estabilidade dimensional e durabilidade no meio bucal (HEKIMOGLU; ANIL, 1999; WILSON, 1989). De acordo com a indicação dos fabricantes, o Mucopren Soft teria uma vida útil de até 4 anos e o Elite Soft de 18 meses, justificando os períodos de imersão utilizados.

Uma das maiores desvantagens ou causa de falhas dos materiais resilientes é a dificuldade em mantê-los limpos (MAKILA; HONKA, 1979). A rotina de limpeza destes materiais é recomendada para remover e prevenir o acúmulo de biofilme (BUTZJORGENSEN, 1979), o qual pode resultar em degradação do material ou instalação de processos patológicos, como a estomatite protética (GRAHAM et al., 1991; NIKAWA et al., 2000). Neste estudo, objetivou-se analisar os efeitos de higienizadores químicos nas propriedades dos reembasadores. 


\subsection{Dureza Shore A}

A dureza é uma propriedade de extrema relevância para os materiais reembasadores resilientes. Segundo Craig e Gibbons (1961), quanto maior a maciez do material, maior a capacidade de absorver os efeitos do impacto mastigatório. Dessa forma, baixa dureza é característica desejável para os reembasadores macios.

Uma forma simples para obtenção da medida do módulo de elasticidade ou da maciez de um elastômero é por meio do ensaio de dureza baseado na mensuração da resistência à penetração de uma ponta romba quando uma força é aplicada. Neste estudo, foi utilizado o durômetro Shore A (Nishi Tokyo Seimitsu Co Ltd, Tokyo, Japão) com força de $1 \mathrm{Kg}$, o qual indica a resistência relativa de um material à penetração de uma ponta sob força de ação constante. Não foi encontrado na literatura um valor ideal de dureza para os reembasadores macios. O valor de dureza obtido pelo durômetro depende da espessura do reembasador, porém a dureza não muda se a espessura exceder $2 \mathrm{~mm}$ (HAYAKAWA et al., 2003). Neste trabalho a espessura selecionada foi de $4 \mathrm{~mm}$, pois quanto maior a espessura, maior a flexibilidade do material (WRIGHT, 1976).

Segundo Canay (1999), os materiais à base de silicone, sofrem mínimas mudanças coesivas, permanecendo macios indefinidamente; porém, a manutenção da dureza constitui um dos fatores mais difíceis na utilização dos reembasadores de próteses totais, já que a maioria deles não é estável em meio aquoso como a cavidade oral. Durante sua utilização, são imersos em saliva, água ou soluções de higiene, o que causa solubilização de componentes, e sorção de água. Segundo Hekimoglu e Anil (1999), alta sorção e solubilidade são associadas com inchaço, distorção, endurecimento, sorção de odores, suporte para crescimento de microrganismos, alterações de cor e deslocamento do reembasador da base da dentadura.

Outros fatores também podem alterar a dureza, como a termociclagem (BATES; SMITH, 1965; HEKIMOGLU; ANIL, 1999; QUDAH; HUGGETT; HARRISON, 1991). Porém, materiais à base de silicone mostram aumento dos valores de dureza, devido à sorção de líquidos pela presença de carga nesse tipo de material (QUDAH; HUGGETT; HARRISON, 1991).

Os resultados deste estudo indicaram um aumento da dureza nos reembasadores após 7 dias, simulando 18 meses de imersão diária de 20 minutos, sendo que este foi maior para o Mucopren Soft $\left(\Delta T^{7}=-8,79\right)$ do que para o Elite Soft $\left(\Delta T^{7}=-4,92\right)$, independente da solução de imersão. Diferenças estruturais podem ter sido responsáveis por este resultado. 
Após 15 dias, o hipoclorito de sódio causou aumento da dureza para o Mucopren soft $\left(\Delta \mathrm{T}^{15}=-11,82\right)$. Esta solução, por ser solução iônica, pode ter promovido a solubilização de componentes, favorecendo a absorção de água pelo material reembasador, causando um aumento da dureza. Os materiais à base de silicone não possuem plastificantes, mas contém carga em sua composição, e a absorção de água pela presença desse componente promove aumento dos valores de dureza dos materiais resilientes (QUDAH; HUGGETT; HARRISON, 1991). Para o Elite Soft, houve uma diminuição dos valores de dureza causados pela mamona. Este resultado contraria o esperado, uma vez que a solução de mamona apresenta grande volume de água. A sorção de soluções aquosas depende do grau de hidrofobicidade e porosidade do material. Materiais que apresentam agentes cross-linked em sua composição, a exemplo do Elite Soft, demonstram maior estabilidade de dureza quando armazenados em meios aquosos. Estudos precisam ser realizados buscando verificar se há interações entre o agente ativo da mamona e os componentes do Elite Soft.

Após 183 dias de imersão, ambos os materiais sofreram um aumento na dureza após a imersão nas soluções, sendo que o hipoclorito foi o responsável pelo maior aumento e a mamona pelo menor.

Pavan et al. (2007) avaliaram a dureza de materiais reembasadores resilientes à base de resina acrílica e silicone após a imersão em glutaraldeído a $2 \%$ e desinfecção em microondas e observaram que o higienizador causou aumento nos valores de dureza nos materiais testados. Bates e Smith (1965) observaram aumento dos valores de dureza de materiais à base de silicone termopolimerizáveis imersos em peróxido alcalino. Embora os meios de imersão não tenham sido os mesmos, estes estudos corroboram com os resultados do presente trabalho. Uma exceção faz-se à interação solução de mamona e Elite Soft. Tan et al. (2000) demonstraram que as médias de dureza do material Molloplast-B (à base de silicone) diminuíram após o tratamento com diferentes soluções de limpeza após quatro meses e meio de imersão. Estes resultados estão de acordo com os encontrados por Oliveira et al. (2007).

Craig e Gibbons (1961) encontraram resultados semelhantes aos do presente estudo ao analisar, entre outras propriedades, a dureza de reembasadores resilientes, 24 horas após o seu processamento e diariamente, durante 20 semanas, em amostras armazenadas em água destilada. Os valores encontrados variaram bastante entre as marcas comerciais testadas após a imersão em água por vinte semanas. Polyzois e Frangou (2001) avaliando a dureza de resina acrílica resiliente e de materiais para forramento ao longo do tempo e com variação nos procedimentos de polimerização, verificaram um aumento da dureza em todos os materiais 
durante o primeiro mês de imersão, e após o qual houve uma estabilização dos valores de dureza.

Os achados literários são ainda controversos, porém indicam uma tendência ao aumento da dureza ao longo do tempo. Neste estudo, o período de imersão de 20 minutos por 18 meses apresentou melhores resultados mesmo para o Mucopren soft, material cuja indicação do fabricante, poderia ser utilizado por até 3 anos.

\subsection{Rugosidade superficial}

Os reembasadores resilientes quando comparados com a resina acrílica sofrem maior colonização por microrganismos, em especial por Candida albicans devido a sua maior rugosidade e presença de porosidades (MACK, 1989; NIKAWA, 1992). Porém, além da rugosidade, outros fatores como composição de material (WHRIGHT, 1980), o envelhecimento do próprio material e fluidos do hospedeiro promovem o crescimento de microrganismos em reembasadores resilientes (NIKAWA et al., 2000).

O parâmetro para obtenção dos valores de rugosidade superficial utilizado nesse estudo foi o Ra. Esse valor corresponde à média aritmética das distâncias absolutas de um perfil de rugosidade em relação à linha central, em um dado comprimento de leitura (SANDERS; LEVIN; REITZ, 1987). Esse parâmetro foi selecionado por ser o mais encontrado na literatura, permitindo comparações com os valores desse estudo.

No presente trabalho, após 7 dias de imersão, a água e o hipoclorito promoveram redução na rugosidade para o Elite soft e aumento para o Mucopren soft. Já a solução de mamona promoveu efeito contrário ao destas soluções na rugosidade dos materiais.

Após 15 dias de imersão todos os materiais sofreram um aumento de sua rugosidade independentemente da solução. Após 183 dias de imersão, o inverso aconteceu, sendo que houve redução da rugosidade dos materiais (Elite Soft: $\Delta \mathrm{T}^{183}=0,30 \mu \mathrm{m}$; Mucopren Soft: $\Delta$ $\left.\mathrm{T}^{183}=0,06 \mu \mathrm{m}\right)$. O hipoclorito de sódio promoveu aumento na rugosidade $\left(\Delta \mathrm{T}^{183}=-0,02 \mu \mathrm{m}\right)$ enquanto que a água $\left(\Delta \mathrm{T}^{183}=0,56 \mu \mathrm{m}\right)$ e a mamona reduziram a rugosidade $\left(\Delta \mathrm{T}^{183}=0,01 \mu \mathrm{m}\right)$. Após imersão em hipoclorito, a perda de componentes solúveis do reembasador pode ter causado a formação de espaços vazios ou bolhas, responsáveis pela rugosidade. Com o decorrer do tempo, essas bolhas podem se transformar em crateras. Os limites da cratera provavelmente são menores quando comparados com os das bolhas, deixando os espécimes mais lisos. A imersão em água promove menor perda de componentes solúveis e não há formação de espaços vazios, logo, a rugosidade não é aumentada (GARCIA et al., 2004). O 
fato de o Elite soft apresentar as maiores alterações na rugosidade pode ser dependente de características inerentes da própria composição do material.

Os resultados de trabalhos que avaliaram a rugosidade superficial de reembasadores resilientes após imersão em solução de limpeza são contraditórios (DAVENPORT; WILSON; BASKER, 1978; HARRISON; BASKER; SMITH, 1989; JAGGER; HARRISON, 1995; JIN et al, 2003; NIKAWA et al., 1994; PAVAN, et al., 2007; GARCIA et al., 2004; SCHMIDT; SMITH, 1983; TAN et al., 2000; OLIVEIRA, 2007; ZISSIS et al., 2000). Existem poucos trabalhos avaliando a rugosidade dos reembasadores frente à imersão em hipoclorito. Tan et al. (2000) não citaram a concentração de hipoclorito usada, mas afirmaram que ele não causou alterações nesta propriedade do reembasador Molloplast B. Porém, muitos trabalhos mostraram haver alteração da rugosidade após imersão em soluções higienizadoras (NIKAWA et al., 1994).

Zissis et al. (2000) observaram valores de rugosidade superficial de diferentes materiais resilientes, variando entre 0,7 a 7,6 $\mu \mathrm{m}$. Radford et al. (1998) encontraram valores, variando de 1,3 a 2,0 $\mu \mathrm{m}$. Essas diferenças nos valores de rugosidade obtidos podem ocorrer em função dos diferentes métodos de obtenção das amostras. Neste presente estudo, a metodologia empregada não utilizou placas de vidro para obtenção dos espécimes de reembasadores, o que poderia ter contribuído para uma superfície mais polida, apresentando menores valores de rugosidade. A obtenção dos corpos-de-prova deste trabalho foi realizada por meio do processamento sobre o gesso da mufla, fato que mais se aproxima da realidade clínica.

A imersão em solução de hipoclorito promoveu aumento significativo da rugosidade superficial após 15 dias. O mesmo ocorreu com o período 183 dias onde a rugosidade sofreu um aumento após exposição à solução de hipoclorito. Davenport, Wilson e Basker (1978) observaram ondulações provocadas pela imersão de um reembasador em solução de hipoclorito, enquanto que Smith e Schmitz (1988) relataram enrugamento do material.

\subsection{Alteração de cor}

Segundo Jin et al. (2003), os fatores que podem contribuir para a alteração de cor dos materiais são vários. Dentre eles incluem-se acúmulo de manchas, desidratação e oxidação das ligações duplas de carbono que ao reagirem, por exemplo, com peróxido (presente em algumas soluções de higiene) produzem compostos coloridos e degradação contínua de produtos coloridos. Embora o processo de alteração de cor dos materiais reembasadores não 
seja exatamente conhecido, ele pode ser atribuído aos diferentes corantes que entram em contato com o meio bucal, às alterações inerentes dos próprios materiais, ou ambas.

Para mensuração da variação de cor, os corpos-de-prova foram avaliados após sua confecção e após 7, 15 e 183 dias de imersão por meio do sistema CIE LAB, frequentemente empregado na literatura (CANAY et al., 1999; JIN et al., 2003; MA; JOHNSON; GORDON, 1997; TAN et al., 2000).

Após 7 dias de imersão, o Elite Soft sofreu a maior alteração de cor quando imerso em hipoclorito $\left(\Delta T^{7}=8,58\right)$ e em mamona $\left(\Delta T^{7}=7,63\right)$. A solução de mamona promoveu a maior alteração de cor no Mucopren Soft $\left(\Delta \mathrm{T}^{7}=2,93\right)$. A estabilidade de cor pode depender da composição química do material (PURNAVEJA et al., 1982). Superfícies hidrofóbicas podem absorver pigmentos por meio de uma interação hidrofóbica.

Após 15 dias de imersão nas soluções de hipoclorito e mamona foi observada a perda da coloração rósea dos reembasadores tornando-se brancos, onde as bordas dos corpos-deprova circulares apresentaram-se mais brancas do que o centro. Tal fato foi observado para ambos os materiais, com mais intensidade quando imersos em hipoclorito do que em mamona. O hipoclorito promoveu uma alteração de cor no Elite $\operatorname{Soft}\left(\Delta \mathrm{T}^{15}=18,21\right)$ maior que no Mucopren Soft $\left(\Delta \mathrm{T}^{15}=5,17\right)$. Oliveira et al. (2007) também observou alteração de cor de reembasadores após imersão em hipoclorito alcalino por 20 minutos durante 90 dias.

Após 183 dias de imersão, o hipoclorito causou maior alteração de cor no Elite $\operatorname{Soft}(\Delta$ $\left.\mathrm{T}^{183}=30,67\right)$ do que no Mucopren Soft $\left(\Delta \mathrm{T}^{183}=24,1\right)$. A solução de mamona promoveu maior alteração de cor no Mucopren Soft $\left(\Delta \mathrm{T}^{183}=8,17\right)$ se comparado ao Elite Soft $\left(\Delta \mathrm{T}^{183}=5,09\right)$. Embora os dois materiais sejam à base de silicone, algo diferente pode existir entre eles que explique os resultados.

Jin et al. (2003) verificaram, em estudo clínico, alteração de cor severa após imersão de reembasadores à base de resina acrílica em higienizadores químicos. Em contraste, um material à base de silicone mostrou os melhores resultados com relação a esta variável. Segundo os autores, algumas das alterações de cor verificadas foram em tom de azul claro, embora as soluções testadas se apresentassem quase incolor. No entanto, considera-se que os corantes dos higienizadores não afetam seriamente a estabilidade de cor dos materiais reembasadores quando comparados aos corantes alimentares como chá e café e outros como o cigarro. Sendo assim, especula-se que as mudanças de cor observadas podem ser atribuídas à mudança na matriz dos materiais, tais como inibição, hidrólise, decomposição de cadeias de reação e desorganização de agentes cross-linked. No entanto, mais estudos são necessários para esclarecer o mecanismo de alteração de cor. 
A alteração de cor é uma propriedade dos materiais reembasadores intimamente ligada à sorção de líquidos pelo material (NIMEROFF, 1968, POWERS; DENNISON; KORAN, 1978). De forma geral, pode ter ocorrido uma alteração de peso dos corpos-deprova devido à absorção de fluidos e solubilidade dos componentes do material, fato que pode ter proporcionado alteração de cor nos reembasadores.

Tan et al. (2000), ao avaliar um material á base de silicone (Molloplast B) verificaram que a alteração de cor do material depende do tipo de higienizador e do acabamento da superfície. Quanto maior a rugosidade superficial do material, maior sua suscetibilidade à alteração de cor. Ma, Johnson e Gordon (1997) verificaram alteração de cor de quatro materiais para reembasamento de próteses totais após imersão em soluções higienizadoras.

A manutenção da cor do material é importante para os pacientes, uma vez que eles apresentam-se mais satisfeitos quando o material reembasador se mantém estável e com a cor indistinguível do material de base da prótese, e a motivação para manter a higiene da dentadura depende da facilidade da limpeza e da ausência de manchas (VILLAR et al., 2003).

Neste estudo os materiais avaliados foram obtidos pela técnica direta, ou seja, com polimerização em temperatura ambiente. Segundo Matsumura et al. (2001), um dos problemas relacionados com a polimerização do material no interior da cavidade bucal é justamente a estabilidade de cor. Entre os demais fatores ligados a esta ocorrência, citados anteriormente, pode-se relacionar também uma camada superficial do material com baixa polimerização. Yatabe, Yasuda e Okabe (1999) relataram que a superfície do material reembasador é facilmente manchada na presença de uma camada onde a polimerização não ocorre perfeitamente e que a espessura desta camada é dependente da temperatura de polimerização, da presença do oxigênio e da proporção pó-líquido. Jin et al. (2003) não detectaram diferenças significantes com os higienizadores de dentadura nos quais materiais reembasadores termopolimerizáveis foram imersos. Segundo os autores, isto pode ser atribuído ao fato de que a termopolimerização proporciona uma maior estabilidade das propriedades físicas dos materiais.

Pôde-se perceber que, independente do período de imersão utilizada, o Mucopren soft apresentou as menores variações na cor, embora esta tenha ocorrido e que, o hipoclorito foi a solução que mais influenciou na alteração desta variável. 


\section{Considerações finais}

Uma limitação deste estudo refere-se ao fato de não terem sido reproduzidas determinadas condições orais, como a associação dos corpos-de-prova à presença de biofilme, $\mathrm{pH}$ salivar e alterações de temperatura, variáveis que podem influenciar a ação de soluções higienizadoras (PARANHOS et al., 2007).

Além disso, existem resultados relacionados à imersão em mamona ainda obscuros. Faz-se necessário um estudo aprimorado da solução na tentativa de explicá-los.

A escolha do higienizador e a seleção do material protético adequados não devem ser feitos embasados somente em uma propriedade e depende do caso clínico em questão. À exemplo dos dentes artificiais, nem sempre aquele de custo mais elevado apresenta os melhores resultados quando suas propriedades são investigadas. 
Por meio dos resultados obtidos, pôde-se concluir:

1. Quanto ao efeito das soluções nas propriedades dos materiais:

1.1 Para a resina acrílica e dentes artificiais, tanto o hipoclorito de sódio quanto a solução de mamona promoveram alterações em suas propriedades, sendo que o hipoclorito, de modo geral, apresentou resultados mais satisfatórios;

1.2 Para os reembasadores resilientes, as duas soluções também alteraram as propriedades, no entanto, a solução de mamona foi a solução que causou as menores.

2. Quanto ao período de imersão:

2.1 Para as resinas acrílicas e dentes artificiais, ambos os períodos de imersão empregados promoveram alteração nas propriedades avaliadas;

2.2 Para os reembasadores resilientes, a simulação de 1 ano e meio com imersões diárias de 20 minutos apresentou melhores resultados que os demais. 
1. ABELSON, D.C. Denture plaque and denture cleansers. J Prosthet Dent., St Louis, v. 45, n. 4, p. 376-9, apr. 1981.

2. ABELSON, D.C. Denture plaque and denture cleansers: review of the literature. Gerodontics, Copenhagen, v. 1, n. 5, p. 202-6, oct. 1985.

3. ABERE, D.J. Post-placement care of complete and removable partial dentures. Dent Clin North Am., Philadelphia, v. 23, n. 1, p. 143-51, jan. 1979.

4. ADAMS, L.P. Biosterometric quantification of clinical denture tooth wear. $\mathbf{J}$ Oral Rehabil., v. 23, p. 667-74, 1996.

5. ALLISON, R.T.; DOUGLAS, W.H. Micro-colonization of the denture fitting surface by Candida albicans. J Dent., v. 1, n. 5, p. 198-201, 1973.

6. ALKHATIB, M.B.; GOODACRE, C.J.; SWARTZ, M.L. Comparison of microwavepolymerized denture base resins. Int J Prosthodont., v. 3, p. 249-255, 1990.

7. AMERICAN DENTAL ASSOCIATION. Specification n. 12 for denture base polymers. Councils on Dental Materials and Devices, Reports of Councils and Bureaus. J Am Dental Assoc., v. 90, p. 39-49, 1975.

8. ANDRUCIOLLI, M.C.D.; MACEDO, L.D.; PANZERI, H.; LARA, E.H.G; PARANHOS, H.F.O. Comparison of two cleasing pastes for the removal of biofilm from dentures and palatal lesions in patients with Atrophic Chronic Candidiasis. Braz Dent J., v. 15, n. 3, p. 220-4, 2004.

9. ANUSAVICE, K.J. Acrylic Resins. Phillps's science of Dental Materials. W.B. Saunders Company 10th ed. p. 140-60, 1996.

10. ARAB, J.; NEWTON, J.P.; LLOYD, C.H. The effect of an elevated level of residual monomer on the whitening of a denture base and its physical properties. J Dent., Bristol, v. 17, n. 4, p. 189-94, aug. 1989. 
11. ARAB, J.; NEWTON, J.P.; LLOYD, C.H. The importance of water temperature in denture cleaning procedures. J Dent., Bristol, v. 16, n. 6, p. 277-81, dec. 1988.

12. AUSTIN, A.T.; BASKER, R.M. Residual monomer levels in denture bases. The effects of varying short curing cycles. Br Dent J., London, v. 153, n. 12, p. 424-6, dec. 1982.

13. AYDIN, A.K.; TERZIOGLU, H.; AKINAY, A.E.; ULUBAYRAM, K.; HASIRCI, N. Bond strength and failure analysis of lining materials to denture resin. Dent Mater., v. 15, n. 3, p. 211-18, may, 1999.

14. AZEVEDO, A.; MACHADO, A.L.; VERGANI, C.E.; GIAMPAOLO, E.T.; PAVARINA, A.C.; MAGNANI, R. Effect of disinfectants on the hardness and roughness of reline acrylic resins. J Prosthodont., v. 15, p. 235-242, 2006.

15. BAFILE, M.; GRASER, G.N.; MYERS, M.L., et al. Porosity in denture resin cured by microwave energy. J Prosthet Dent., v. 66, p. 269-274, 1991.

16. BARBOSA, D.B; SOUZA, R.F; PERO, A.C; MARRA, J.; COMPAGNONI, M.C. Flexural strength of acrylic resins polymerized by different cycles. J Appl Oral Sci.v. 15, n. 5, p. 424-8, 2007.

17. BARNABÉ, W.; de MENDONÇA NETO, T.; PIMENTA, F.C.; PEGORARO, L.F.; SCOLARO, J.M. Efficacy of sodium hypochlorite and coconut soap used as disinfecting agents in the reduction of denture stomatitis, Streptococcus mutans and Candida albicans. J Oral Rehabil., Oxford, v. 31, n. 5, p. 453-9, may 2004.

18. BARROS, V. M. R.; ROSA, A. L.; CHIERICE, G.; PIRES, R. O. M. Osseointegração do implante de poliuretano em fêmur de coelhos. In: Reunião da SBPqO, 18. Resumos da $18^{\mathrm{a}}$ Reunião da SBPqO, Águas de Lindóia, 2001. v. 18, p. 41, resumo I152.

19. BASSON, N.J.; QUICK, A.N.; THOMAS, C.J. Household products as sanitization agents in denture cleansing. J Dent Assoc S Afr., v. 47, n. 10, p. 437-9, oct. 1992. 
20. BATES, J.F; SMITH, D.C. Evaluation of indirect resilient liners. J Am Dent Assoc., Chicago, v. 70, n. 2, p. 344-53, feb. 1965.

21. BEALL, J.R. Wear of acrylic resin teeth. J Am Dent Assoc., v. 30, n. 1, p. 252-6, 1943.

22. BELL, J.A.; BROCKMANN, S.L.; FEIL, P.; SACKUVICH, D.A. The effectiveness of two disinfectants on denture base acrylic resin with an organic load. J Prosthet Dent., St. Louis, v. 61, n. 5, p. 580-3, may. 1989.

23. BELOTI, M. M.; HIRAKI, K. R.; BARROS, V. M.; ROSA, A. L. Effect of the chemical composition of Ricinus communis polyurethane on rat bone marrow cell attachment, proliferation, and differentiation. J Biomed Mater Res., v. 64, n.1, p. 171-176, 2003.

24. BOLLEN, C.M.L.; LAMBRECHTS, P.; QUIRYEN, M. Comparison of surface roughness of oral hard materials to the threshold surface roughness for bacterial plaque retention: a review of the literature. Dent Mater., v. 13, n. 4, p. 258-69, 1997.

25. BOUCHER, C.O.; HICKEY, J.C.; ZARB, G.A. Prosthodontic treatment for edentulous pacients. $7^{\text {th }}$ ed. St. Louis: C V Mosby; 1975, p.37-8.

26. BRADEN, M. The absorption of water by acrylic resins and other materials. $\mathbf{J}$ Prosthet Dent., v. 14, p. 307-16, 1964.

27. BUDTZ-JORGERSEN, E. Materials and methods for cleaning dentures. J Prosthet Dent., St. Louis, v. 42, n. 6, p. 619-23, dec. 1979.

28. BURROW, M.F.; MAKINSON, O.F. Color change in light cured resins exposed to daylight. Quintessence Int., v. 22, p.447-452, 1991.

29. BUYUKYILMAZ, S.; RUYTER, I.E. Color stability of denture base polymers. Int J Prosthodont., Lombard, v. 7, n. 4, p. 372-82, jul/aug. 1994. 
30. CALIXTO, R.F.E.; TEÓFILO, J.M.; BRENTEGANI, L.G.; LAMANO CARVALHO, T.L. Implante de um floculado de resina de mamona em alvéolo dental de rato. Pesqui Odontol Bras., v. 15, n. 3, p. 257-262, 2001

31. CAMPANHA, N.H.; PAVARINA, A.C.; VERGANI, C.E.; MACHADO A.L. Effect of microwave sterilization and water storage on the Vickers hardness of acrylic resin denture teeth. J Prosthet Dent., v. 93, p. 483-7, 2005.

32. CANAY, S.; HERSEK, N.; TULUNOGLU, I.; UZUN, G. Evaluation of colour and hardness changes of soft lining materials in food colorant solutions. J Oral Rehabil., Oxford, v. 26, n. 10, p. 821-29, Oct., 1999.

33. CARVALHO, T.L.L.; TÉOFILO, J.M.; ARAÚJO, J.M.; ARAÚJO, C.A.C. A.; BRENTEGANI, L.G. Chronology of alveolar healing following immediate implantation of Ricinus comunis polyurethane resin: histométrica analysis in rats. J Biomed Mater Res., v. 37, n. 4, p. 449-452, 1997.

34. CHAN, E.C.S.; IOGOVAZ, I.; SIBOO, R.; BILYK, M.; BAROLET, R.; AMSEL, R.; WOOLEY, C.; KLITORINOS, A. Comparison of two popular methods for removal and killing of bacteria from dentures. J Can Dent Assoc., v. 57, n. 12, p. 937-9, 1991.

35. CHAU, V.B.; SAUNDERS, T.R.; PIMSLER, M.; ELFRING, D.R. In-depth disinfection of acrylic resins. J Prosthet Dent., St. Louis, v. 74, n. 3, p. 309-13, sep. 1995.

36. COMPAGNONI, M.A.; BARBOSA, D.B.; DE SOUZA, R.F.; PERO A.C. The effect of polymerization cycles on porosity of microwave-processed denture base resins. J Prosthet Dent., v. 91, n. 3, p. 281-285, mar. 2004.

37. COOLEY, R.L.; BARKMEIER, W.W.; MATIS, B.A.; SIOK, J.F. Staining of posterior resin restorative materials. Quintessence Int., v. 18, p. 823-827, 1987.

38. CORNELL, J.A.; JORDAN, J.S.; ELLIS, S.; ROSE, E.E. A method of comparing the wear resistance of various materials used for artificial teeth. J Am Dent Assoc., v. 54, n. 5, p. 608-14, may. 1957. 
39. COSTA, C.A.S. Biocompatibilidade do polímero de poliuretana vegetal derivada do óleo de mamona em estudo comparativo com cimento de óxido de zinco e eugenol. Avaliação histopatológica de implantes subcutâneos de ratos. Odonto 2000 - Odontologia do Século XXI, v. 1, p. 44-8, 1997.

40. COUNCIL ON DENTAL MATERIALS, INSTRUMENTS AND EQUIP-MENT. Denture cleansers. J Am Dent Assoc., v. 106, n. 1, p. 77-9, jan. 1983.

41. COUNCIL ON DENTAL THERAPEUTICS AND COUNCIL ON PROSTHETIC SERVICES AND DENTAL LABORATORY RELATIONS. Guidelines for infection control in the dental office and the commercial dental laboratory. J Am Dent Assoc., Chicago, v. 110, n. 6, p. 969-72, jun. 1985.

42. CRAIG, R.G., GIBBONS, P. Properties of resilient denture liners. J Am Dent Assoc., Chicago, v. 63, p. 65-72, Sep. 1961.

43. CRAIG, R.G.; O’BRIEN, M.J.; POWERS, J.M. Propriedades dos materiais. In: Materiais dentários: propriedades e manipulaçao. 3 ed. Rio de janeiro. Guanabara KOogan, 1988, Cap 2, p. 17

44. CRAIG, R.G.; POWERS, J.M. Materiais dentários restauradores. $11^{\mathrm{a}}$ ed. São Paulo: Livraria Editora Santos, 2004. 704p.

45. CRAIG, R.G.; WARD M.L. Restorative dental materials. $10^{\text {th }}$ ed., Mosby, St Louis, p. 30-32, 1997.

46. CRAWFORD, C.A.; LLOYD, C.H.; NEWTON, J.P.; YEMM, R. Denture bleaching: a laboratory simulation of patients`cleaning procedures. J Dent., Bristol, v. 14, n. 6, p. 258-61, dec. 1986.

47. CRAWFORD, C.A.; NEWTON, J.P.; YEMM, R. Bleached dentures: misuse of a denture-cleaning agent. Dent Update, London, v. 14, n. 1, p. 29-32, jan/feb. 1987. 
48. DARBAR, U.R.; HUGGETT, R.; HARRISON, A. Denture fracture-a survey. Br Dent J., v. 176, p. 342-5, 1994.

49. DAVENPORT, J.C.; WILSON, H.J.; BASKER, R.M. The compability of tissue conditioners with denture cleaners and chlorhexidine. J Dent., v.6, n.3, p. 239-46, Sep., 1978.

50. DAVENPORT, J.C.; WILSON, H.J.; SPENCE, D. The compatibility of soft lining materials and denture cleansers. Br Dent J., London, v. 161, n. 1, p. 13-7, 1986.

51. DE CLERCK, J.P. Microwave polymerization of acrylic resins used in dental prostheses. J Prosthet Dent., v. 57, p. 650-8, 1987.

52. DEVLIN, H.; BEDI, R. Denture use and abuse. Dent Update., v. 15, p. 78-80, 1988.

53. DEVLIN, H.; KAUSHIK, P. The effect of water absorption on acrylic surface properties. J Prosthodont., Philadelphia, v. 14, n. 4, p. 233-8, dec. 2005.

54. DIKBAS, I.; KOKSAL, T.; CALIKKOCAOGLU, S. Investigation of the cleanliness of dentures in a university hospital. Int J Prosthodont., Lombard, v. 19, n. 3, p. 294-8, may/jun. 2006.

55. DILLS, S.S.; OLSHAN, A.M.; GOLDNER, S.; BROGDON, C. Comparison of the antimicrobial capability of an abrasive paste and chemical-soak denture cleansers. J Prosthet Dent., St. Louis, v. 60, n. 4., p. 467-70, oct. 1988.

56. DOGAN, A.C; EVIK, N.N.; USANMAZ, A. The effect of preparation conditions of acrylic denture base materials on the level of residual monomer, mechanical properties and water absorption. J Dent., v. 23, p. 313-8, 1995.

57. EL-HADARY, A.; DRUMMOND, J.L. Comparative study of water sorption, solubility, and tensile bond strength of two soft lining materials. J Prosthet Dent., St. Louis, v. 83, n. 3, p. 356-61, mar. 2000. 
58. FERRACANE, J.L. Materials in Dentistry: principles and applications. Philadelphia: Lippincott Williams and Wilkins, 2 ed., p. 98-100, 2001.

59. FERRACANE, J.L.; MOSER, J.B.; GREENER, E.H. Ultraviolet light-induced yellowing of dental restorative resins. J Prosthet Dent., v. 54, p. 483-487, 1985.

60. FERREIRA, C.M.; BONIFACIO, K.C.; FRONER, I.C.; ITO, I.Y. Evaluation of the antimicrobial activity of three irrigation solutions in teeth with pulpal necrosis. Br Dent J., v. 10, n. 1, p. 15-21, 1999.

61. FERREIRA, C.M.; ROSA, O.P.S.; TORRES, S.A.; FERREIRA, F.B.A.; BERNARDINELLI, N. Activity of endodontic antibacterial agents against selected anaerobic bactéria. Braz Dent J., v. 13, n. 2, p. 118-122, 2002.

62. FURUKAWA, K.K. Effectiveness of clorine dioxide in disinfection of two soft denture liners. J Prosthet Dent., v. 80, n. 6, p. 723-729, dec. 1998.

63. GARCIA JUNIOR, A. Avaliação da eficácia dos desinfetantes químicos na desinfecção de resina acrílica termopolimerizável. 2002. 101p. + anexos. Dissertação (Mestrado) - Faculdade de Odontologia de Ribeirão Preto, Universidade de São Paulo, Ribeirão Preto, 2002.

64. GARCIA, R.C.M.R.; SOUZA Jr, J.A.; RACHED, R.N.; DEL BEL CURY, A.A. Effect of denture cleansers on the surface roughness and hardness of a microwave-cured acrylic resin and dental alloys. J Prosthodont., v. 13, p. 173-178, 2004.

65. GETTLEMAN, L.; NATHANSON, D.; MYERSON, R.L. Effect of rapid curing procedures on polymer implants materials. J Prosthet Dent., v. 37, n. 1, p. 74-82, 1977.

66. GOLDSTEIN, G.R.; SCHMITT, G.W. Repeatability of a specially designed intraoral colorimeter. J. Prosthet. Dent., St. Louis, v.69, n.6, p.616, Jun., 1993

67. GOLL, G.; SMITH, D.E.; PLEIN, J.B. The effect of denture cleansers on temporary soft liners. J Prosthet Dent., St. Louis, v. 50, n. 4, p. 466-72, oct. 1983. 
68. GORNITSKY, M.; PARADIS, I.; LANDAVERDE, G.; MALO, A.; VELLY; A.M. A Clinical and Microbiological Evaluation of Denture Cleansers for Geriatric Patients in LongTerm Care Institutions. J Can Den Assoc., Canadá, v. 68, n. 1, p. 39-45, jan. 2002.

69. HARRISON, A. Clinical results of the measurements of occlusal wear of complete dentures. J Prosthet Dent., v. 35, n. 5, p. 504-11, may. 1976.

70. HARRISON, A.; BASKER, R.M.; SMITH, I.S. The compatibility of temporary soft materials with immersion denture cleansers. Int J Prosthodont., Lombard, v. 2, n. 3, p. 254, may-jun. 1989.

71. HARRISON, A.; HUGGET, R. Measuring the rate of wear of artificial teeth in complete dentures. J Prosthet Dent. v. 33, n. 6, p. 615-9, june. 1975.

72. HARRISON, A.; HUGGETT, R. Effect of the curing cycle on residual monomer levels of acrylic resin denture base polymers. J Dent., v. 20, p. 370-4, 1992.

73. HARRISON, Z.; JOHNSON, A.; DOUGLAS, C.W.I. An in vitro study into the effect of a limited range of denture cleaners on surface roughness and removal of Candida albicans from conventional heat-cured acrylic resin denture base material. J Oral Rehabil., v. 31, p. 460-467, 2004.

74. HASELDEN, C. A.; HOBKIRK, J. A.; PEARSON, G. J. DAVIES, E. H. A comparison between the wear resistances of three types of denture resin to three different dentifrices. J Oral Rehabil., v. 25, n. 5, p. 335-339, 1998.

75. HAYAKAWA I.; KEH, E.S.; MORIZAWA, M.; MURAOKA, G.; HIRANO, S. A new polyisopropene-based light-curing denture soft lining material. J Dent., v. 31, p. 269-74, 2003.

76. HEKIMOGLU, C.; ANIL, N. Sorption and solubility of soft denture liners after accelerated aging. Am J Dent., USA, v. 12, n. 1, p. 44-6, Feb., 1999. 
77. HIRAKI, K.R.N.; BARROS, V.M.R.; BELOTI, M.M.; ROSA, A.L. Biocompatibilidade in vitro do polímero de mamona. In: Reunião da SBPqO, 18. Resumos da $18^{\text {a }}$ Reunião da SBPqO, Águas de Lindóia, 2001. v. 18, p. 42, resumo I161.

78. HIRANO, S.; MAY, K.B.; WAGNER, W.C.; HACKER, C.H. In vitro wear of resin denture teeth. J Prosthet Dent., v. 79, n. 2, p. 152-155, 1998.

79. HOAD-REDDICK, G.; GRANT, A. A.; GRIFFITHS, C. S. Investigation into the cleanliness of dentures in an elderly population. J Prosthet Dent., St Louis, v. 64, n. 1, p. 4852, jul. 1990.

80. HUTCHINS, D.W.; PARKER, W.A. A clinical evaluation of the ability of denture cleaning solutions to remove dental plaque from prosthetic devices. N Y State Dent J., New York, v. 39, n. 6, p. 363-7, jun./jul. 1973.

81. IAZETTI, G.; BURGESS, J.O.; GARDINER, D.; RIPPS, A. Color stability of fluoride-containing restorative materials. Oper. Dent., v. 25, p. 520-525, 2000.

82. IGNÁCIO, H.; MAZZER, N.; BARBIERI, C. H.; CHIERICE, G. O. Utilização da poliuretana da mamona nas formas compacta e porosa no preenchimento de falha óssea: estudo experimental em cães. Rev Bras Ortop., v. 37, n. 5, p. 187-194, 2002.

83. INOKOSHI, S.M.B.; BURROW, M.F.; KATAUMI, M.; YAMADA, T.; TAKATSU, T. Opacity and color changes of tooth-colored restorative materials. Oper Dent., v.21, p.7380, 1996.

84. INTERNATIONAL STANDARDIZATION ORGANIZATION. Dentistry- denture base polymer- ISO 1567. 3 ed. Géneve: ISO; 1999-2002, 27p.

85. ITO, I.; FRÖNER, I.C.; MIAN, H.; CHIERICE, G.O. Castor oil: antimicrobial activity of detergent derived from ricinolic acid [abstract]. J Dent Res., v. 78, p. 344, 1999.

86. JAGGER, D.C.; HARRISON, A. Denture cleansing - the best approach. Br Dent J., London, v. 178, n. 11, p. 413-7, jun. 1995. 
87. JIN, C.; NIKAWA, H.; MAKIHIRA, S.; HAMADA, T.; FURUKAWA, M.; MURATA, H. Changes in surface rougness and colour stability of soft denture lining materials caused by denture cleansers. J Oral Rehabil., Oxford, v. 30, n. 2, p. 125-30, feb. 2003.

88. JOHN, J.; GANGADHAR, S.A.; SHAH, I. Flexural strength of heat polymerized polymethyl methacrylate denture resin reinforced with glass, aramid, or nylon fibers. J Prosthet Dent., v. 86, p. 424-7, 2001.

89. JOHNSON, W.M.; KAO, E.C. Assessment of appearance match by visual observation and clinical colorimetry. J Dent Res., Washington, v.68, n.5, p.819, May., 1989.

90. KANLI, A.; DEMIREL, F.; SEZGIN, Y. Oral candidosis, denture cleanliness and hygiene habits in elderly population. Aging Clin Exp Res., v. 17, n. 6, p. 502-7, dec. 2005.

91. KAWANO, F.; OHGURI, T.; ICHIKAWA, T.; MIZUNO, I.; HASEGAWA, A. Shock absorbability and hardness of commercially available denture teeth. Int J Prosthodont., v. 15, p. 243-7, 2002.

92. KIAT-AMNUAY, S.; GETTLEMAN, L.; MEKAYARAJJANANONTH, T.; KHAN, Z.; GOLDSMITH, L.J. The influence of water storage on durometer hardness of 5 soft denture liners over time. J Prosthodont., USA, v. 14, n. 1, p. 19-24, mar. 2005.

93. KIMURA, H.; TERAOKA, F.; OHNISHI, H.; SAITO, T.; YATO, M. Applications of microwave for dental technique (part 1). Dough-forming and curing of acrylic resins. J Osaka Univ Dent Sch., Osaka, v. 23, p. 43-9, dec. 1983.

94. KIMURA, H.; TERAOKA, F.; SAITO, T. Application of microwave for dental technique (part 2). Adaptability of cured acrylic resins. J Osaka Univ Dent Sch., Osaka, v. 24, p. 21-9, dec. 1984.

95. KOKSKAL, T.; DIKBAS, F. Color stability of different materials against various staining agents. Dent Mater J., v. 27, n. 1, p. 139-44, 2008. 
96. KULAK, Y.; ARIKAN, A.; ALBAK, S.; OKAR, I.; KAZAZOGLU, E. Scanning electron microscopic examination of different cleaners: surface contaminant removal from dentures. J Oral Rehabil., Oxford, v. 24, n. 3, p. 209-15, mar. 1997.

97. KULAK-OZKAN, Y.; KAZAZOGLU, E.; ARIKAN, A. Oral hygiene habits, denture cleanliness, presence of yeasts and stomatitis in elderly people. J Oral Rehabil., Oxford, v. 29, n. 3, p. 300-4, mar. 2002.

98. LAI , Y.L.; LUI, H.F.; LEE, S.Y. in vitro color stability, stain resistance, and water sorption of four removable gingival flange materials. J Prosthet Dent., v. 90, p. 293-300, 2003.

99. LAI, C.P.; TSAI, M.H.; CHEN, M.; CHANG, H.S.; TAY, H.H. Morphology and properties of denture acrylic resins cured by microwave energy and conventional water bath. Dent Mater., v. 20, n. 2, p. 133-141, 2004.

100. LAMIE, G.A.; STORER, R. A preliminary report on resilient denture plastics. J Prosthet Dent., St. Louis, v. 8, p. 411-24, 1958.

101. LANGWELL, W.H. The cleansing of artificial dentures. Br Dent J., London, v. 15, n. 11, p. 337-9, nov. 1955.

102. LEE, H.E.; WANG, C.C.; WANG, J.C.; CHEN, C.P. the effect of denture cleansers and cleaning methods on the microflora of denture plaque. Kaohsivng-Hsueh Ko Hsueh., v. 1, n. 2, p. 88, feb. 1985.

103. LEE, S.Y.; LAI, Y.L.; HSU, T.S. Influence of polymerization conditions on monomer elution and microhardness of autopolymerized polymethyl methacrylate resin. Eur J Oral Sci., v. 110, n. 2, p. 179-183, apr. 2002.

104. LEVIN, B.; SANDERS, J.L.; REITZ, P.V. The use of microwave energy for processing acrylic resins. J Prosthet Dent., v. 61, p. 381-383, 1989. 
105. LIBERMAN, R.; COMBE, E.C.; PIDDOCK, V.; PAWSON, C.; WATTS, D.C. Development and assessment of an objective method of colour change measurement for acrylic denture base resins. J Oral Rehabil., Oxford, v. 22, n. 6, p. 445-9, jun. 1995.

106. LIMA, E.M.C.X.; MOURA, J.S.; DEL BEL CURY, A.A; GARCIA, R.C.M.R.; CURY J.A. Effect of enzymatic and $\mathrm{NaOCl}$ treatments on acrylic roughness and on biofilm accumulation. J Oral Rehabil., v. 33, p. 356-362, 2006.

107. LOVE, W.D.; GOSKA, F.A.; MIXSON, R.J. The etiology of mucosal inflammation associated with dentures. J Prosthet Dent., St. Louis, v. 18, n. 6, p. 515-27, dec. 1967.

108. LOYAGA-RENDON, P.G.; TAKAHASHI , H.; HAYAKAWA, I.; IWASAKI N. Compositional characteristics and hardness of acrylic and composite resin artificial teeth. $\mathbf{J}$ Prosthet Dent., v. 98, n. 2, p. 141-9, aug. 2007.

109. LUCE, M.S.; CAMPBELL, C.E. Stain potential of four microfilled composites. J Prosthet Dent., v. 60, p. 151-154, 1988.

110. MA, S.; JOHNSON, G.H.; GORDON, G.E. Effects of chemical disinfectants on the surface characteristics and color of denture resins. J Prosthet Dent., St. Louis, v. 77, n. 2, p. 197-204, feb. 1997.

111. MACCALLUM, M.; STAFFORD, G.D.; MACCULLOCH, W.T.; COMBE, E.C. Wich cleanser? A report on a survey of denture cleansing routine and the development of a new denture cleanser. Dent Pract Dent Rec., Bristol, v. 19, n. 3, p. 83-9, nov. 1968.

112. MACHADO, A.L.; BREEDING, L.C.; PUCKETT, A.D. Effect of microwave disinfection on the hardness and adhesion of two resilient liners. J Prosthet Dent., St. Louis, v. 94, n. 2, p. 183-89, aug. 2005.

113. MACHADO, C; SANCHEZ, E; AZER, S.S; URIBE, J.M. Comparative study of the transverse strength of three denture base materials. J Dent., v. 35, n. 12, p. 930-3, Oct. 2007. 
114. MACK, P.J. Denture soft lining materials: clinical indications. Austral Dent. J., Australia, v.34, n.5, p.454-58, Oct., 1989.

115. MAKILA, E.; HONKA, O. Clinical study of a heat-cured silicone soft lining material. J Oral Rehabil., Oxford, v. 6, n. 2, p. 199-204, apr. 1979.

116. MALHEIROS-SEGUNDO, A.L.; PISANI, M.X.; PARANHOS, H.F.O.; SOUZA, R.F.; SILVA-LOVATO, C.H. Effect of a denture cleanser on hardness, roughness and tensile bond strength of denture liners. Braz J Oral Sci., São Paulo, v.7, n.26, p.1596-1601, 2008.

117. MANDIKOS, M.N.; McGIVNEY, G.P.; DAVIS, E. BUSH, P.J.; CARTER, J.M. A comparison of the wear resistance and hardness of indirect composite resins. $\mathbf{J}$ Prosthet Dent., v. 85, p. 386-395, 2001.

118. MANTESSO, A; FRÖNER, I.C.; CHIERICE, G.O.; JAEGER, M.M.M. In vitro citotoxy evaluation of the mamona solution. J Dent Res., v. 79, n. 5, p. 1075, (abstract A050), 2000.

119. MARTINS, R.G.; LACERDA, T.S.P.; CARVALHO, J.A.; MAURI, A.C.; ZANETTI, A.L. Métodos para higienização de próteses totais e sua importância: revisão da literatura. Rev Odontol UNICID, São Paulo, v. 16, n. 2, p. 169-76, maio/ago. 2004.

120. MATSUMURA, H.; TANOUE, N.; KAWASAKI, K.; ATSUTA M. Clinical evaluation of a chemically cured hard denture relining material. J Oral Rehabil., Oxford, v. 28, n. 7, p. 640-44, Jul., 2001.

121. MAY, K.B.; SHOTWELL, J.R.; KORAN, A.3rd.; WANG, R.F. Color stability: denture base resins processed with the microwave method. J Prosthet Dent., St. Louis, v. 76, n. 6, p. 581-9, dec. 1996.

122. McCABE, J.F. Soft lining materials: composition and structure. J Oral Rehabil., Oxford, v.3, n.3, p.273-78, Jul., 1976. 
123. MCNEME, S.J.; VON GONTEN, A.S.; WOOLSEY, G.D. Effects of laboratory disinfecting agents on color stability of denture acrylic resins. J Prosthet Dent., St. Louis, v. 66, n. 1, p. 132-6, jul. 1991.

124. MELLO, P.C. Avaliação da resistência à abrasão, microdureza superficial e estabilidade de cor de dentes artificiais de resina acrílica. Ribeirão Preto, 2007.109p. Dissertação (Mestrado) - Faculdade de Odontologia de Ribeirão Preto, Universidade de São Paulo, 2007.

125. MINAGI, S.; TSUNODA, T.; YOSHIDA, K.; TSURU, H. Objective testing of the efficiency of denture cleansing agents. J Prosthet Dent., St. Louis, v.58, n.5, p.395-98, nov. 1987.

126. MINER, J.F. The nature of a denture base: a key factor in denture sore mouth. $\mathbf{J}$ Prosthet Dent., v. 29, n. 3, p. 250-5, mar. 1973.

127. MOORE, T.C.; SMITH, D.E.; KENNY, G.E. Sanitization of dentures by several denture hygiene methods. J Prosthet Dent., St. Louis, v. 52, n. 2, p. 158-63, aug. 1984.

128. MORAN, M.; ZUCKERBERG, D. A.; MONICA, F. Denture cleanser plaque removal and antibacterial effects. J Dent Res., Washington, v. 62, n. 3, p. 171, Abstract 13, mar. 1983.

129. MUTLUAY, M.M.; OGUZ, S.; FLOYSTRAND, F.; SAXEGAARD, E.; DOGAN, A.; BEK, B.; RUYTER, I.E. A prospective study on the clinical performance of polysiloxane soft liners: one-year results. Dent Mater J., v. 27, n. 3, p. 440-7, may 2008.

130. MUTLU-SAGESEN, L.; ERGUN, G.; OZKAN, Y.; BEK, B. Color stability of different denture teeth materials: an in vitro study. J Oral Science., v. 43, n. 3, p. 193-205, Sep. 2001.

131. NEILL, D.J. A study of materials and methods employed in cleaning dentures. Br Dent J., London, v. 124, n. 3, p. 107-15, feb. 1968. 
132. NEPPELENBROEK, K.H.; PAVARINA, A.C.; VERGANI, C.E.; GIAMPAOLO, E.T. Hardness of heat-polymerized acrylic resins after disinfection and long-term water immersion. J Prosthet Dent., v. 93, n. 2, p. 171-6, feb. 2005.

133. NIKAWA, H.; HAMADA, T.; YAMAMOTO, T. Denture plaque - past and recent concerns. J Dent., Bristol, v. 26, n. 4, p. 299-304, may 1998.

134. NIKAWA, H.; IWANAGA, H.; KAMEDA, M.; HAMADA, T. In vitro evaluation of Candida albicans adherence to soft denture-lining materials. J. Prosthet. Dent., St. Louis, v. 68, n.5, p.804-08, Nov., 1992.

135. NIKAWA, H.; JIN, C.; HAMADA, T.; MAKIHIRA, H.; KUMAGAI, H.; MURATA, H. Interactions between thermal cycled resilient denture lining materials, salivary and serum pellicles and Candida albicans in vitro: Part II. Effects on fungal colonizatrion. J Oral Rehabil., Oxford, v. 27, n. 2, p. 124-30, Feb., 2000.

136. NIKAWA, H.; JIN, C.; MAKIHIRA, H.; EGUSA, H.; HAMADA, T.; KUMAGAI, H. Biofilm formation of Candida albicans on the surfaces of deteriorated soft denture lining materials caused by denture cleansers in vitro. J Oral Rehabil., Oxford, v. 30, n. 3, p. 24350, mar. 2003.

137. NIKAWA. H.; IWANAGA, H.; HAMADA, T.; YUHTA, S. Effects of denture cleansers on direct soft dentures lining materials. J Prosthet Dent., St. Louis, v. 72, n. 6, p. 657-62., dec. 1994.

138. NIMEROFF, L. Colorimetry. DC: Nat. Bureau Stand. Monograph $\mathbf{n}^{\mathbf{1}} 104$. Washington, 47, 1968.

139. NISHII, M. Studies on curing of denture base resin with curing resins. J. Osaka Univ. Dent. Sch., Osaka, v. 2, p. 23-40, fev., 1968.

140. NOGUEIRA, C.M. Effects of denture cleansers agents upon artificial teeth hardness. J Dent Res., v. 81, (sp issue), p. 179, dec. 2002. 
141. O'BRIEN, W.J. et al. Color distribution of three regions of extracted human teeth. Dent. Mater., v. 13, n. 3, p. 179-185, 1997.

142. OGLE, R.E.; DAVID, L.J.; ORTMAN, H.R. Clinical wear study of a new tooth material: part II. J Prosthet Dent., v. 54, p. 67-75, 1985.

143. OGLE, R.E.; DAVIS, E.L. Clinical wear study of three commercially available artificial tooth materials: thirty-six month results. J Prosthet Dent., v. 79, p. 145-151, 1998.

144. OHARA, G.H.; KOJIMA, K.E.; ROSSI, J.C.; TELLES, M.; SOARES, T.V.C.; SALOMÃO, C. Estudo experimental da biocompatibilidade do polímero poliuretano da mamona implantada intra - óssea e intra - articular em coelhos. Acta Ortop Bras., v. 3, n. 2, p. 62-8, 1995.

145. OLIVEIRA, L.V.; MESQUITA, M.F.; HENRIQUES, G.E.P.; CONSANI, R.L.X. The Effect of Brushing on Surface Roughness of Denture Lining Materials. J. Prosthodont., USA, v. 16, n. 3, p. 179-84, May-Jun., 2007.

146. PARANHOS, H.F.O.; LARA, E.H.G.; PANZERI, H.; CANDIDO, R.C.; ITO, I.Y. Capacity of denture plaque/biofilm removal and antimicrobial action of a new denture paste. Braz Dent J., v. 11, n. 2, p. 97-104, 2000.

147. PARANHOS, H.F.O.; MALACHIAS, A.; PARDINI, L.C. Materiais para limpeza de dentaduras: Revisão da literatura. Rev Fac Odontol Lins, Lins, v. 4, n. 2, p. 19-24, jul./dez. 1991.

148. PARANHOS, H.F.O.; PARDINI, L.C.; PANZERI, H. Hábitos de higienização de portadores de prótese total. Rev Paul Odontol., São Paulo, v. 12, p. 11-21, 1991.

149. PARANHOS, H.F.O.; SILVA-LOVATO, C.H.; SOUZA, R.F.; CRUZ, P.C.; FREITAS, K.M.; PERACINI, A. Effects of mechanical and chemical methods on denture biofilm accumulation. J Oral Rehabil., v. 34, p. 606-612, 2007. 
150. PARR, G.R.; RUEGGEBERG, F.A. In vitro hardness, water sorption, and resin solubility of laboratory-processed and autopolymerized long-term resilient denture liners over one year of water storage. J Prosthet Dent., St. Louis, v. 88, n. 2, p. 139-44, aug. 2002.

151. PASCON, E.L. Biocompatibilidade dos materiais endodônticos: biocompatibilidade da resina poliuretana derivada da mamona. Ribeirão Preto, 1999, 104p. Tese (Doutorado) - Faculdade de Odontologia de Ribeirão Preto, Universidade de Ribeirão Preto.

152. PAVAN, S.; ARIOLI FILHO, J.N.; DOS SANTOS, P.H.; NOGUEIRA, S.S.; BATISTA, A.U. Effect of disinfection treatments on the hardness of soft denture liner materials. J Prosthodont., USA, v. 16, n. 2, p. 101-06, mar/apr. 2007.

153. PAVARINA, A.C.; MACHADO, A.L.; GIAMPAOLO, E.T.; VERGANI, C.E. Effects of chemical disinfectants on the transverse strength of denture base acrylic resins. $\mathbf{J}$ Oral Rehabil., Oxford, v. 30, n. 11, p. 1085-9, nov. 2003(b).

154. PAVARINA, A.C.; PIZZOLITTO, A.C.; MACHADO, A.L.; VERGANI, C.E; GIAMPAOLO, E.T. An infection control protocol: effectiveness of immersion solutions to reduce the microbial growth on dental prostheses. J Oral Rehabil., Oxford, v. 30, n. 5, p. 532-6, may 2003(a).

155. PAVARINA, A.C.; VERGANI, C.E.; MACHADO, A.L.; GIAMPAOLO, T.; TERAOKA, M.T. The effect of disinfectant solutions on the hardness of acrylic resin denture teeth. J Oral Rehabil., v. 30, p. 749-752, 2003(c).

156. PÉCORA, J.D.; MARCHESAN, M.; SOUZA NETO, M.; GUERISOLI D.M.Z.; DA SILVA, R.S. Effects of Ricinus communis detergent and pain gel on radicular permeability. J Israel Dent Assoc., v. 17, n. 2, p. 9-11, 2000

157. PERACINI, A. Avaliação in vitro da ação do hipoclorito de sódio e pastilhas efervescentes quanto à alteração de cor em resinas acrílicas termopolimerizáveis e de microondas. Ribeirão Preto, 2008. 124p. Dissertação (Mestrado) - Faculdade de Odontologia de Ribeirão Preto, Universidade de São Paulo, 2008. 
158. PEYTON, F.A. History of resins in dentistry. Dent Clin North Am., v. 19, n. 2, p. 211-22, apr. 1975.

159. Phillips Materiais Dentários. $11^{a}$ ed. Rio de Janeiro: Elsevier; 2005. Cap. 22, 764p.

160. PHILLIPS, R.W. Materiais dentários de Skinner. $8^{\mathrm{a}}$. ed. Rio de Janeiro: Interamericana, 1984. Cap. 12, p.126-138.

161. PINTO, J.R.R.; MATHIAS, A.C.; DE PAULA EDUARDO, J.V.; SINHORETI, M.A.C.; MESQUITA, M.F. Estudo dos materiais reembasadores resilientes em Prótese Total. Rev Assoc Paul Cir Dent., v. 56, p. 131-4, 2002.

162. POLYZOIS, G.L. Denture cleansing habits. A survey. Aust Dent J., v. 28, n. 3, p. 171-73, jun. 1983.

163. POLYZOIS, G.L.; FRANGOU, M.J. Influence of curing method, sealer, and water storage on the hardness of a soft lining material over time. J Prosthodont., USA, v. 10, n. 11, p. 42-5, Mar., 2001.

164. POLYZOIS, G.L.; YANNIKAKIS, S.A.; ZISSIS, A.J.; DEMETRIOU, P.P. Color changes of denture base materials after disinfection and sterilization immersion. Int $\mathbf{J}$ Prosthodont., Lombard, v. 10, n. 1, p. 83-9, jan./feb. 1997.

165. POPPER, F. Undercuts and resilient denture liners. J Dent Assoc South Afr., v. 19, p. 77-81, 1945.

166. POWERS, J.M.; DENNISON, J.B.; KORAN, A. Color stability of restorative resins under accelerated aging. J Dent Res., USA, v.57, n.11-12, p.964-70, Nov-Dec., 1978.

167. POWERS, J.M.; LEPEAK, P.J. Parameters that affect the color of denture resins. J Dent Res., Chicago, v. 56, n. 11, p. 1331-5, nov. 1977. 
168. PURNAVEJA, S.; FLETCHER, A.M.; RITCHIE, G.M.; AMIN, W.M.; MORADIANS, S.; DODD, A.W. Compatibility of denture cleansers with some new self curing denture base materials. Biomaterials., v. 3, n. 4, p. 251-2, Oct., 1982.

169. QUDAH, S.; HARRISON, A.; HUGGETT, R. Soft lining materials in prosthetic dentistry: a review. Int J Prosthodont., Lombard, v.3, n.3, p.477-83, Sep-Oct., 1990.

170. QUDAH, S.; HUGGETT, R.; HARRISON, D. The effect of thermocycling on the hardness of soft lining materials. Quintessence Int., Berlim, v. 22, n. 7, p. 575-80, Jul., 1991.

171. RADFORD, D.R.; CHALLACOMBE, S.J.; WATER, J.D. Denture plaque and adherence of Candida albicans to denture base materials in vivo and in vitro. Crit Rev Oral Biol Med., v. 10, n.1, p. 99-116, 1999.

172. RADFORD, D.R.; SWEET, S.P.; CHALLACOMBE, S.J.; WALTER, J.D. Adherence of Candida albicans to denture-base materials with different surface finishes. J Dent., v. 26, n. 7, p. 577-83, 1998.

173. RAHAL, S.J.; MESQUITA, M.F. Influência dos polimentos mecânico e químico sobre propriedades de resinas acrílicas ativadas termicamente. Piracicaba, 2001. Dissertação (mestrado em Clínica Odontológica)- Faculdade de Odontologia de Piracicaba, Universidade Estadual de Campinas. 161p.

174. REITZ, P.V.; SANDERS, J.L.; LEVIN, B. The curing of denture acrylic resins by microwave energy. Physical properties. Quintessence Int., v. 16, p. 547-551, 1985.

175. RICHMOND, R.; MACFARLANE, T. V.; McCORD, J. F. An evaluation of the surface changes in PMMA biomaterial formulations as a result of toothbrush/dentifrice abrasion. Dent Mater., v. 20, n. 2, p. 124-132, 2004.

176. ROBINSON, J.G.; MCCABE, J.F.; STORER, R. Denture bases: the effects of various treatments on clarity, strengh and structure. J Dent., Bristol, v. 15, n. 4, p. 159-65, aug. 1987. 
177. ROBINSON, J.G.; MCCABE, J.F.; STORER, R. The whitening of acrylic dentures: the role of denture cleansers. Br Dent J., London, v. 159, n. 8, p. 247-50, oct. 1985.

178. RODRIGUES, J.A.; MARCHI, G.M.; AMBROSANO, G.M.; HEYMANN, H.O.; PIMENTA, L.A. Microhardness evaluation of in situ vital bleaching on human dental enamel using a novel study design. Dent Mat., v. 21, n.11, nov. 2005.

179. ROTH, J.A.; FLEMING, L. An update on the effectiveness of denture cleansers. W V Dent J., v. 54, p. 14-6, 1980.

180. RUDD, R.W.; SENIA, E.S.; MCCLESKEY, F.K.; ADAMS, E.D.Jr. Sterilization of complete dentures with sodium hypochlorite. J Prosthet Dent., St. Louis, v. 51, n. 3, p. 31821, mar. 1984.

181. RUSSELL, E.A. Jr. Management of mucoepidermoid carcinoma of the palate. Report of a case. Oral Surg. Oral Med. Oral Pathol., v.41, n.4, p.436-40, apr. 1976.

182. RUYTER, I.E; NILNER, K.; MOLLER, B. Color stability of dental composite resin materials for crow and bridge veneers. Dent Mater., v. 3, p. 246-251, 1987.

183. SADAMORI, S.; GANEFIYANTI, T.; HAMADA, T.; ARIMA, T. Influence of thickness and location on the residual monomer content of denture base cured by three processing methods. J Prosthet Dent., v. 72, p. 19-22, 1994.

184. SADAMORI, S.; SHIGETO, N.; HAMADA, T.; OKUDA, K. A method of determining residual monomer in acrylic resin using methyl ethyl ketone. Aust. J. Dent., v. 35, n.6, p. 509-13, jan/dez., 1990.

185. SANDERS, J.L.; LEVIN, B.; REITZ, P.V. Porosity in denture acrylic resins cured by microwave energy. Quintessence Int., v. 18, p. 453-456, 1987.

186. SARAÇ, D.; SARAÇ, S.; KURT, M.; YÜZBASIOGLU, E. The effectiveness of denture cleansers on soft denture liners colored by food colorant solutions. J Prosthodont., USA, v. 16, n. 3, p. 185-91, may/jun. 2007. 
187. SATO, S.; CAVALCANTE, M.R.S.; ORSI, I.A.; PARANHOS, H.F.O.; ZANIQUELLI, O. Assessment of flexural strenght and color alteration of heat-polymerized acrylic resins after simulated use of denture cleansers. Braz Dent J., Ribeirão Preto, v. 16, n. 2, p. 124-8, may/aug. 2005.

188. SATOH, Y.; NAGAI, E.; MAEJIMA, K.; MATSUZU, R.; MATSUZU, M.; KOBAYASHI, E.; TOYOMA, H.; OHWA, M.; OHKI, K. Wear of denture teeth by use of metal plates - part 2: abrasive wear of posterior teeth. J Nihon Univ Sch Dent., v. 34, n. 1, p. 16-27, 1992.

189. SATOH, Y.; OHTANI, K.; MAEJIMA, K.; MORIKAWA, M.; MATSUZU, M.; NAGAI, E.; TOYOMA, H.; OHWA, M.; OHKI, K.; KAKETANI, M.; NISHIYAMA, M. Wear of artificial denture teeth by use of toothbrushes. Part 1: Abrasive wear of anterior teeth. J Nihon Univ Sch Dent., v. 32, n. 4, p. 247-258, 1990.

190. SCHAEFER, M.E. Infection control in dental laboratory procedures. CDAJ., v. 13, p. 81-4, 1985.

191. SEGHI, R.R. Effects of instrument-measuring geometry on clorimetric assessments of dental porcelains. J Dent Res., v. 69, p. 1180-1183, 1990.

192. SEGHI, R.R.; JOHNSTON, W.M.; O’BRIEN, W.J. Performance assessment of colorimetric devices on dental porcelain. J Dent Res., v. 68, p. 1755-1759, 1989.

193. SEXSON, J.C.; PHILLIPS, R.W. Studies on the effects of abrasives on acrylic resins. J Prosthet Dent., v. 1, n. 4, p. 454-71, jul. 1951.

194. SHANNON, I.L.; STARCKE, E.N. Higher performance denture cleansers. N Y J Dent., Brooklyn, v. 48, n. 8, p. 246-50, oct. 1978.

195. SHAY, K. Denture hygiene: a review and update. J Contemp Dent Pract., v. 1, p. 28-41, 2000. 
196. SHAY, K.; TRUHLAR, M.R.; RENNER, R.P. Oropharyngeal Candidosis in the older patient. J Am Geriatr Soc., v. 45, n. 7, p. 863-70, jul. 1997.

197. SHEEN, S.R.; HARRISON, A. Assessment of plaque prevention on dentures using an experimental cleanser. J Prosthet Dent., v. 84, n. 6, p. 594-601, 2000.

198. SHEN, C.; JAVID, J.S.; COLAIZZI, I.A. The effect of glutaraldehyde base disinfectants on denture base resins. J Prosthet Dent., St. Louis, v. 61, n. 5, p. 583-89, may. 1989.

199. SILVA, C.H.L.; PARANHOS, H.F.O.; ITO, I.Y. Evidenciadores de biofilme em prótese total: avaliação clínica e antimicrobiana. Pesqui Odontol Bras., v. 16, n. 3, p. 270-5, 2002.

200. SILVA, C.H.L.; PARANHOS, H.F.O.; MELLO, P.C.; CRUZ, P.C.; FREITAS, K.M.; MACEDO, L.D. Levantamento do grau de instruções e dos materiais e métodos de higiene utilizados por usuários de próteses totais. Rev Odontol UNESP., v. 35, n.2, p. 125-131, 2006.

201. SINOBAD, D.; MURPHY, W.M.; HUGGET, R.; BROOKS, S. Bond strength and rupture properties of some soft denture liners. J Oral Rehabil., Oxford, v. 19, n. 2, p. 151-60, mar. 1992.

202. SIQUEIRA, D.C.R. Avaliação comparative in vivo da atividade antimicrobiana do hipoclorito de sódio a $1 \%$, da clorexidina a $2 \%$ e do detergente derivado do oleo de mamona a 10\% utilizados como soluções irrigadoras em endodontia. 2005. 110p. Dissertação (Mestrado)- Faculdade de Odontologia de Bauru, Universidade de São Paulo, Bauru, 2005.

203. SMITH, D.C. The cleansing of dentures. Dent Pract Dent Rec., Bristol, v. 17, n. 2, p. 39-43, oct. 1966.

204. SMITH, L.S.A.; SCHMITZ, V. The effect of water sorption on the glass transition temperature of poly (methyl methacrylate). Polymer., v. 29, p. 1871-8, 1988. 
205. SMITH, L.T.; POWERS, J.M.; LADD, D. Mechanical properties of new denture resins polymerized by visible light, heat and microwawe energy. Int J Prosthodont., v. 5, n. 4, p. 315-20, 1992.

206. STAFFORD, G.D.; BATES, J.F., HUGGET, R.; HANDLEY, R.W. A review of the properties of some denture base polymers. J Dent, v. 8, n. 4, p. 292-306, 1980.

207. STORER, R. Resilient denture base materials. Part 2. Br Dent J., London, v. 113, p. 231-38, 1962.

208. SUZUKI, S.; TAMURA, F. In vitro wear of nano-composite denture teeth. Int. J. Prosthodont., v. 13, p. 238-243, 2004.

209. TAKAHASHI, Y; KAWAGUCHI, M; CHAI, J. Flexural strength at the proportional limit of a denture base material relined with four different denture reline material. Int $\mathbf{J}$

210. TAN, H.; WOO, A.; KIM, S.; LAMOUREUX, M.; GRACE, M. Effect of denture cleansers, surface finishing, and temperature on molloplast b resilient liner color, hardness, and texture. J Prosthodont., USA, v. 9, n. 3, p. 148-55, sep. 2000.

211. TANQUE, N.; MATSUMURA, H.; ATSUTA, M. Wear and surface roughness of current prosthetic composits after toothbrush/dentifrice abrasion. J Prosthet Dent., v. 84, n. 1, p. 93-97, 2000.

212. TARBET, W.J.; AXELROD, S.; MINKOFF, S.; FRATARCANGELO, P,A. Denture cleansing: a comparison of two methods. J Prosthet Dent., St Louis, v. 51, n. 3, p. 322-25, mar. 1984.

213. TEIXEIRA, F.B.; FERRAZ, C.C.R.; ZAIA, A.A.; GOMES, B.P.F.A.; SOUZAFILHO, F.J.; OLIVEIRA, D.P. Remoção de smear layer dos canais radiculares utilizando oirrigante Endoquil. RBO, v. 58, n. 6, p. 424-426, 2001.

214. TYLMAN, S.D. The use of elastic and resilient synthetic resins and their copolymer in oral, dental and facial prostheses. Dent Digest., v. 49, p. 167-96, 1943. 
215. ÜNLÜ, A.; ALTAY, O.T.; SAHMALI, S. The role of denture cleansers on the whitening of acrylic resins. Int J Prosthodont., Lombard, v. 9, n. 3, p. 266-70, may/jun. 1996.

216. VALLITTU, P.K. The effect of surface treatment of denture acrylic resin on the residual monomer content and its release into water. Acta Odontol. Scand, v. 54, n. 3, p. 188-92, 1996.

217. VALLITTU, P.K.; LASSILA, V.P.; LAPPALAINEN, R. Wetting the repair surface with methyl methacrylate affects the transverse strength of repaired heat-polymerized resin. $\mathbf{J}$ Prosthet Dent., v. 72, p. 639-43, 1994.

218. VAN DER BURGT, T.P.; TEN BORCH, J.J.; BORSBOOM, P.C.; KOETSMIT, W.J. A comparison of new and conventional methods for qualification of tooth color. $\mathbf{J}$ Prosthet Dent., v. 63, n. 2, p. 155-162, 1990.

219. VAN NOORT, R. Introdução aos materiais dentários. 2 ed. Porto Alegre: Artmed, p. 245-256, 2004.

220. VILLAR, A.; PESUN, I.J; BROSKY, M.E.; FINES, C.; HODGES, J.S.; DELONG, R. Clinical evaluation of a new resilient denture liner. Part 1: Compliance and color evaluation. $\mathbf{J}$ Prosthodont., USA, v. 12, n. 2, p. 82-9, Jun., 2003.

221. VON FRAUNHOFER , J.A.; RAZAVI, B.S.R.; KHAN, Z. Wear characteristics of high-strenght denture teeth. J Prosthet Dent., v. 59, n. 2, p. 173-5, 1988.

222. VON FRAUNHOFER, J.A.; SUCHATLAMPONG, C. The surface characteristics of denture base polymers. J Dent., v. 3, p. 105-9, 1975.

223. WATKINSON, A.C.; MCCREIGHT, M.C.; WORNOCK, D.W. Prevalence and persistence of different strains of Candida albicans in treatment of denture stomatitis. $\mathbf{J}$ Prosthet Dent., St. Louis, v. 53, n. 3, p. 365-6, mar. 1985. 
224. WEAVER, R.E.; GOEBEL, W.M. Reaction to acrylic resin dental prosthesis. J Prosthet Dent., v. 43, n. 2, p. 138-42, 1980.

225. WEBB, B.C.; WILLCOX, M. D. P.; THOMAS, C.J.; HARTY, D.W.S.; KNOX, K.W.; The effect of sodium hypochlorite on potential pathogenic traits of Candida albicans and other Candida species. Oral Microbiol Immunol., Copenhagen, v. 10, n. 6, p. 334-41, dec. 1995.

226. WHITMAN, D.J. et al. In vitro wear rates of three types of commercial denture tooth materials. J Prosthet Dent., v. 57, p. 243-246, 1987.

227. WILSON, H. J. Materiais dentários e suas aplicações clínicas. São Paulo: Santos, 1989. cap. 9, p. 101-9.

228. WINKLER, S.; MONASKY, G.E.; KWOK, J. Laboratory wear investigation of resin posterior denture teeth. J Prosthet Dent., v. 67, n. 6, p. 812-814, 1992.

229. WRIGHT, P.S. Characterization of the adhesion of soft lining materials to poli(methyl methacrylate). J Dent Res., Washington, v.61, n.8, p.1002-05, Aug., 1982.

230. WRIGHT, P.S. Soft lining materials: their status and prospects. J. Dent., Guildford, v.4, n.6, p.247-56, nov. 1976.

231. YANNIKAKIS, S.; ZISSIS, A; POLYZOIS, G., et al. Evaluation of porosity in microwave-processed acrylic resin using a photographic method. J Prosthet Dent., v. 87, p. 613-619, 2002.

232. YATABE, M.; YASUDA, N.; AI, M.; OKABE, Y. Unpolymerized layer on autopolymerizing hard reline materials. Int. J. Prosthodont., Lombard, v. 12, n. 2, p.129, mar-apr., 1999.

233. YILMAZ H.; AYDIN, C.; BAL BT., ÕZÇELIT B. Effects of disinfectants on resilient denture-lining materials contaminated with Staphilococcus aureaus, Streptococcus sobrinus and Candida albicans. Quintessence Int., Berlim, v. 36, n. 5, p. 373-81, may. 2005. 
234. YIU, C.K.; KING, N.M.; PASHLEY, D.H.; SUH, B.I.; CARVALHO, R.M. CARRILHO, M.R.; TAY, F.R. Effect of resin hydrofilicity and water storage on resin strength. Biomaterials., v. 25, n. 26, p. 5789-96, 2004.

235. ZARB, G.A.; BOLENDER, C.L.; CARLSSON, G.E. Boucher's Prosthodontic Treatment for Edentulous Patients. $11^{\text {th }}$. Ed. Mosby, St. Louis, 2000. 558p.

236. ZENG, J.; SATO, Y.; OHKUBO, C.; HOSOI, T. In vitro wear resistance of three types of composite resin denture teeth. J Prosthet Dent., v. 94, p. 453-457, 2005.

237. ZISSIS, A.J.; POLYZOIS, G.L.; YANNIKAKIS, A.S.; HARRISON, A. Roughness of denture materials: a comparative study. Int J Prosthodont., Lombard, v.13, n.2, p.136-40, Mar-Apr., 2000. 